\title{
THE GENERA OF DIAPRIINAE \\ (HYMENOPTERA: DIAPRIIDAE) IN THE NEW WORLD
}

\author{
LUBOMÍR MASNER \\ Research Associate, Division of Invertebrates, \\ American Museum of Natural History \\ Research Associate, Agriculture and Agri-Food Canada \\ Research Branch, K.W. Neatby Building \\ Ottawa, Ontario, Canada K1A OC6
}

\begin{abstract}
JOSÉ LUIS GARCÍA R.
Curator, Museo del Instituto de Zoologia Agricola "Dr Francisco

Fernández Yépez,"

Facultad de Agronomía, Universidad Central de Venezuela Apartado 4579, Maracay, 2101-A, Edo. Aragua, Venezuela
\end{abstract}

BULLETIN OF THE AMERICAN MUSEUM OF NATURAL HISTORY

CENTRAL PARK WEST AT 79TH STREET, NEW YORK, NY 10024

Number 268, 138 pp., 107 figures, 1 table

Issued April 18, 2002 


\section{CONTENTS}

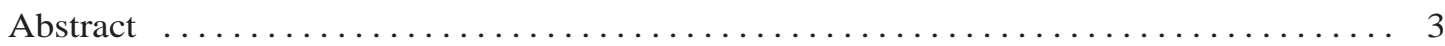

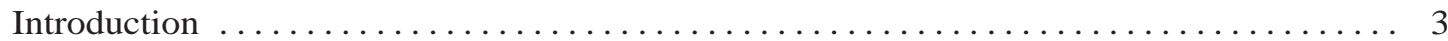

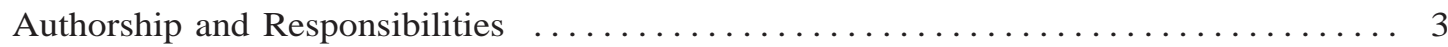

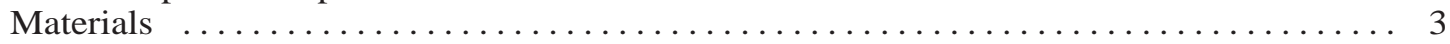

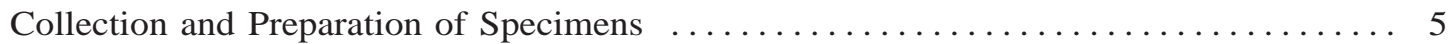

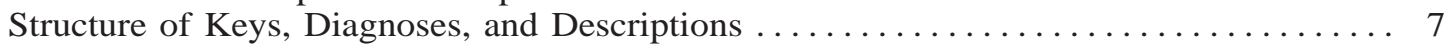

Higher Classification and Interrelationships $\ldots \ldots \ldots \ldots \ldots \ldots \ldots \ldots \ldots \ldots \ldots \ldots \ldots \ldots \ldots \ldots$

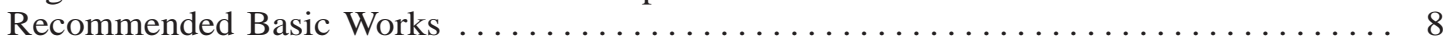

Taxonomic List of Diapriinae Genera Described $\ldots \ldots \ldots \ldots \ldots \ldots \ldots \ldots \ldots \ldots \ldots$

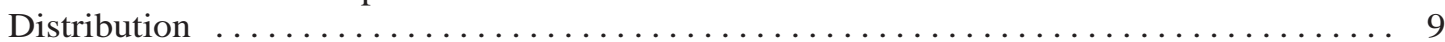

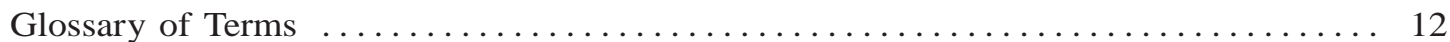

Key to Diapriinae Genera in the New World ..................... 15

Clave para la Separación de los Géneros de Diapriinae del Nuevo Mundo ........ 22

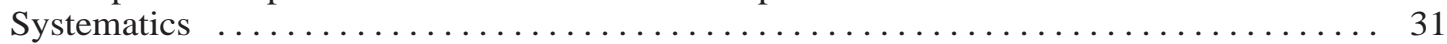

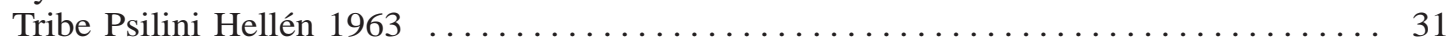

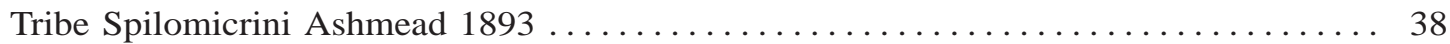

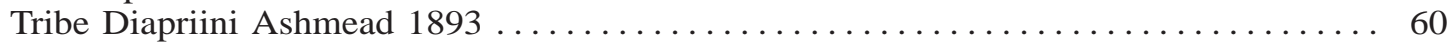

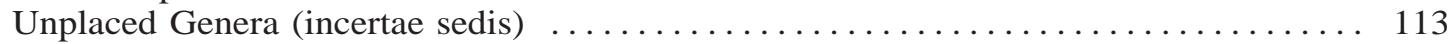

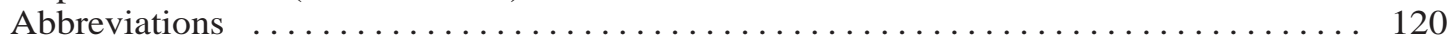

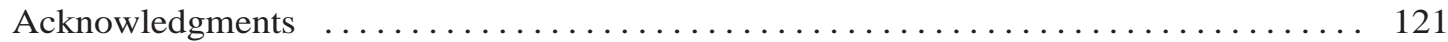

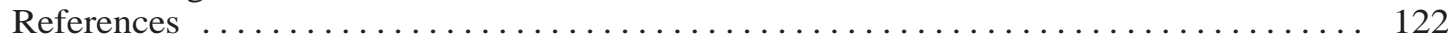

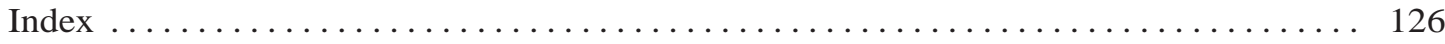

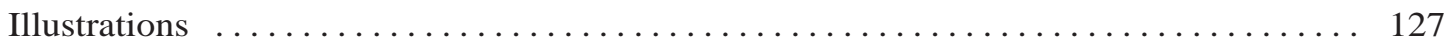




\begin{abstract}
The subfamily Diapriinae (Diapriidae: Proctotrupoidea) in the New World is reviewed at the supra specific level. Three tribes and 52 genera are recognized. Sixteen new genera are proposed: Apopria (Diapriini), Avoca (Diapriini), Chilomicrus (Spilomicrini), Cruzium (Diapriini), Doddius (Spilomicrini), Eladio (Diapriini), Epomium (Spilomicrini), Ferrugenus (Spilomicrini), Hansona (Diapriini), Leucopria (Diapriini), Mimopriella (Diapriini), Omopria (Diapriini), Ortona (Psilini), Peckidium (incertae sedis) Psychopria (Diapriini), and Turripria (Diapriini). The following new species are described: Apopria coveri o (USA), Asolenopsia gibba q (Costa Rica), Avoca collaris $q$ (USA), Chilomicrus pecki ô (Chile), Cruzium amphorale ㅇ (Costa Rica), Eladio cruzi 오 (Costa Rica), Epomium cicatrix 우 (Chile), Ferrugenus chi-

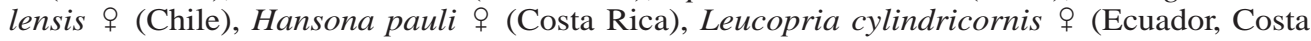
Rica), Omopria brevipalpis $q$ (Brazil), Ortona hansoni + (Costa Rica), Peckidium enigmaticum $q$ (Antilles, Central and South America, West Africa, Philippines), Psychopria hoguei ô (Costa Rica), Turripria woldai + (Panama). New generic synonymies are proposed: Acanthopria Ashmead (=Adelioneiva Fischer), Asolenopria Kieffer (=Euplacopria Ferrière), Bruchopria Kieffer (=Aulatopria Brèthes), Doliopria Kieffer (=Martinica Risbec), Megaplastopria Ashmead (=Xyalopria Kieffer), Notoxoides Ashmead (=Psilogasteroides Brèthes), Pentapria Kieffer (=Antipapria Fabritius, Bakeria Kieffer, Plutopria Kieffer, Spilomicrinus Ogloblin), Spilomicrus Westwood (=Hoplopria Ashmead, Linkiola Kieffer), Szelenyiopria Fabritius (=Gymnopria Loiácono). New combinations are proposed: Aulatopria tucumana Brèthes to Bruchopria, Bakeria rugosa Dodd to Doddius, Gymnopria lucens Loiacono to Szelenyiopria, Mimopria pentatoma Borgmeier and Mimopria splendens Borgmeier to Mimopriella, and Xanthopria nitida Brues to Acanthopria. The 52 genera are keyed (keys in both English and Spanish); for each genus the synonymies, diagnoses, descriptions, recognition and relationships, distribution, and biology are given. Twelve plates with 107 figures are included.
\end{abstract}

\section{INTRODUCTION}

The principal purpose of this paper is to provide, for the first time, a key to genera of the Diapriinae in the New World. We also present generic diagnoses and descriptions to further assist the users. Brief discussions on relationships, distribution, and biology of each genus should build a base for study by future students. The Spanish version of the generic key is intended to spark interest in this group by students in Latin America. We did not dwell on higher classification or attempt a cladistic analysis. We believe that this type of exercise should be conducted on a global scale, i.e., include the Old World taxa. However, our generic concepts are based on phylogenetic principles of shared derived characters; a discussion of most of the character states and their polarization can be found in Masner and Huggert (1989).

It is our earnest belief and hope that this paper will spotlight Diapriinae wasps as a potential focus group for biodiversity studies. The surprisingly large extent of the Diapriinae, its species richness, and its biological diversity, are ideal for this purpose. Diapriines penetrate many microhabitats and mi- croniches, flourish even in harsh habitats (e.g., páramos of the Andes, barren oceanic islands, and frigid forests of Patagonia), and are generally caught in large numbers in all types of traps and methods of sampling.

\section{AUTHORSHIP AND RESPONSIBILITIES}

This is a joint project, with all new taxa to be credited to Masner and García. Also, all taxonomic revisions, such as new synonymies, new combinations, as well as concepts of supraspecific taxa reflect the views of both authors. José Luis García translated the key into Spanish.

\section{MATERIALS}

Materials were borrowed from or studied in the following museums or private collections (in alphabetical order, with standard acronyms and curator's name):

AEIC D. B. Wahl: American Entomological Institute, 3005 SW 56th Ave., Gainesville, FL 32608, USA

AMNH J. Carpenter: Department of Entomology Collection, American Museum of Natural History, Central Park West at 79th Street, New York, NY 10024, USA 
BMNH M. Fitton: Department of Entomology, The Natural History Museum, Cromwell Road, London SW7 5BD, London, England

CASC W. Pulawski: Department of Entomology, California Academy of Sciences, Golden Gate Park, San Francisco, CA 94118, USA

CDAE J. Sorensen: California State Collection of Arthropods, California Department of Food \& Agriculture, 1220, N. Street, Sacramento, CA 95814, USA

CMNH J. E. Rawlins: Section of Insects and Spiders, Carnegie Museum of Natural History, 900 Forbes Ave., Pittsburgh, PA 15213, USA

CNCI J. Huber: Canadian National Collection of Insects, Eastern Cereal \& Oilseed Research Centre, Agriculture Canada, Ottawa, ON K1A 0C6, Canada

CUCC M. W. Heyn: Department of Entomology Collection, Clemson University, Clemson, SC 29631, USA

CUIC J. K. Liebherr Cornell University Insect Collection, Department of Entomology, Cornell University, Ithaca, NY 14850, USA

DBUM M. Coulloudon: Collection Entomologique Ouellet-Robert, Département des Sciences Biologiques, Université de Montréal, C.P. 6128, Montréal, QC H3C 3J7, Canada

DENH D. S. Chandler: University of New Hampshire Insect Collection, Department of Entomology, University of New Hampshire, Durham, NH 03824, USA

EMEC J. A. Chemsak: Essig Museum of Entomology, Department of Entomological Sciences, University of California, Berkeley, CA 94720, USA

FMNH A. F. Newton: Insect Collection, Field Museum of Natural History, Roosevelt Road and Lake Shore Drive, Chicago, IL 60605, USA

FSCA M. C. Thomas: Florida State Collection of Arthropods, Division of Plant Industry, P. O. Box 147100, Gainesville, FL 32614, USA

IMLC A. Willink (deceased): Instituto Miguel Lillo, Tucuman, Argentina

INBC J. Ugalde: Instituto Nacional de Biodiversidad, Santo Domingo, Costa Rica

INHS L. M. Page: Illinois Natural History Survey, Insect Collection, 607 E. Peabody Drive, Champaign, IL 61820, USA
IZAC J. Genaro: Instituto de Zoologia, Academia de Ciencias de Cuba, Habana, Cuba

LACM J. P. Donahue: Insect Collection, Los Angeles County Museum of Natural History, 900 Exposition Blvd., Los Angeles, CA 90007, USA

LEMQ T. A. Wheeler: Lyman Museum, St. Anne de Bellevue, QC H9X 3M1, Canada

MCZC J. Perkins: Entomology Department, Museum of Comparative Zoology, Harvard University, 26 Oxford St., Cambridge, MA 02138, USA

MHNS M. Elgueta: Museo Nacional Historia Natural, Santiago, Chile

MIUP D. Quintero: Museo de Invertebrados, Universidad de Panama, Panama

MIZA J. L. García: Museo de Instituto de Zoologia Agricola, Maracay, Venezuela

MNHG C. Besuchet: Museum d'Histoire Naturelle, Geneva, Switzerland

MNHP F. W. Stehr: Department of Entomology Collection, Michigan State University, East Lansing, MI 48824-1115, USA

ROME D. C. Darling: Department of Entomology, Royal Ontario Museum, Toronto, ON M5S 2C6, Canada

SEMC R. W. Brooks: Snow Entomological Museum, University of Kansas, Lawrence, KS 66044, USA

TAMU J. Oswald: Texas A\&M University, College Station, TX 77843, USA

UADE C. E. Carlton: Department of Entomology Collection, University of Arkansas, Fayetteville, AR 72701, USA

UAIC F. G. Werner (deceased): Department of Entomology Collection, University of Arizona, Tucson, AZ 85721, USA

UBCC G. G. E. Scudder: University of British Columbia, Vancouver, BC V6T 1Z4, Canada

UCDC L. S. Kimsey: The Bohart Museum of Entomology, University of California, Davis, CA 95616, USA

UCMC U. N. Lanham: University of Colorado Museum, Box 218, Boulder, CO 80309, USA

UCRC S. Trjapitsyn: UCR Entomological Teaching and Research Collection, University of California, Riverside, CA 92521, USA

UGCA C. Smith: Museum of Natural History, Entomology Collection, University of Georgia, Athens, GA 30602, USA

ULQC J. M. Perron: Université de Laval, Ste. Foy, QC G1K 7P4, Canada 
USNM D. R. Smith: United States National Entomological Collection, Department of Entomology, US National Museum of Natural History, Washington, DC 20560, USA

ZMHB B. Petersen (deceased): Zoologisk Museum, Universitets Copenhagen, Denmark

The single major source of material not borrowed from the institutions above was the Canadian National Collection (CNCI) in Ottawa, with holdings greater than all other sources combined. Almost all the CNCI material is freshly collected, with specimens not older than 25 years; over 60 individuals, colleagues, and friends kindly contributed over the years by donating specimens. Ten contributors are truly outstanding because of the magnitude and quality of material supplied: Stewart B. Peck and Jarmila Kukalova-Peck (Carleton University, Ottawa), Alfred Newton and Margaret Thayer (FMNH, Chicago), Robert Brooks and J. Steve Ashe (SEMC, Lawrence KS), B. Brown (LACM, Los Angeles), Fred D. Bennett (formerly CIBC, Trinidad, W.I.), John S. Noyes (BMNH, London), and Paul Hanson (Universidad de Costa Rica, San José, Costa Rica). Extensive collections were recently acquired from the following expeditions: Bolivia (Masner, 1997), Chile (Masner, 1988), Costa Rica (Masner and Goulet, 1985; Masner, 1986, 1995, 1996, 1998), Cuba (Masner, 1995), Dominican Republic (Masner, 1978, 1987, 1990, 1991, 1994), Ecuador (Masner and Sharkey, 1983), Mexico (Masner, 1993), Venezuela (Masner, 1981, 1992; Masner and García, 1994). The cutoff date for material and data used in this paper was June 1999.

\section{COLLECTION AND PREPARATION OF SPECIMENS}

We strongly believe that fieldwork is an integral part of any biosystematic study. Field experience and fresh material collected and prepared by the taxonomist cannot be substituted by outside loans, no matter how extensive or diverse the materials may be. Collecting and its techniques should help us penetrate all niches and levels of insect life. It is only natural that in these days of high technology we strive to advance the tools and techniques that were initiated 200 years ago.
Screen sweeping (s.s.). Large $(50 \times 40$ $\mathrm{cm})$ sweeping net on a lightweight aluminum frame with screen of strong mesh $(0.7 \mathrm{~cm}$ opening) sewn into the upper part of the net about $20 \mathrm{~cm}$ below the net edge will eliminate most plant debris during sweeping. Insects falling through the screen are collected at the bottom of the net, the tip of which is cut off and closed with vinyl-coated wire, and emptied into a plastic bag containing $70 \%$ ethanol. The entire catch is subsequently rinsed in fresh water and transferred to $70 \%$ ethanol. This method is by far the most productive, particularly in the early stages of surveying any habitat.

Large aerial net ("Maxinet"). For aerial sampling, a large $(100 \mathrm{~cm})$ circular net on a lightweight aluminum frame (four detachable parts), with no additional screen is used. This technique allows collecting immediately after rain and is generally suitable in the tropics during the rainy season. Aerial sampling is recommended during crepuscule and nighttime. The contents are emptied into a plastic bag with $70 \%$ ethanol, then rinsed with fresh water and transferred to $70 \%$ ethanol.

Pan trapping (YPT). Yellow plastic pan traps of various shapes and sizes filled with brine and a few drops of surfactant will collect numerous species from the ground floor and the lower levels in many habitats. Pan traps often yield both sexes; hence, proper sex associations are facilitated for species with a high degree of sexual dimorphism. Pan traps operated sequentially during the entire season will also provide valuable data on species frequencies, species replacement, duration of flight period, etc. Best results are with large numbers (100-200) of smaller pans in microhabitats, operated over 24-48 hours. (Brine or other preservatives are not needed.) In longterm sampling (more than 48 hrs) high salinity is required for preservation, and thorough rinsing in water before storage in alcohol is imperative.

Interception trap (FIT) (Masner and Goulet, 1981). This is actually a version of the pan trap with a flight barrier. A sheet of black (or dark green) densemesh polyester fabric $(120 \times 150 \mathrm{~cm})$ treated with pyrethroid (e.g., Ambush) and set over a large trough of yellow plastic filled with brine and 
surfactant is used primarily for intercepting low- and slow-flying insects.

Photoeclector. A collecting device based on positive phototropism of most insects. Swept material is placed in a dark box with an escape passage into a smaller light box attached to it. Screens on the side of the light box are treated with pyrethroid; insects drop to a container filled with brine. For better portability in the field the photoeclector could be designed as a backpack. The photoeclector, vastly superior for collecting larger members of the Hymenoptera, e.g., sawflies and aculeates, has somewhat limited use for diapriine wasps.

Car net (Peck and Cook, 1992). Two cones of fabric nets $(100 \times 100 \mathrm{~cm})$ installed on a metal frame and placed in front of the car bumper, approximately $30 \mathrm{~cm}$ above ground, will collect clean material. Apices of the nets are treated with pyrethroid and the material is emptied by a cordless vacuum cleaner. This method will allow the surveillance of a large area in a relatively short time any time of the day or night.

Malaise trap (MT). A modified Townes' version (Townes, 1972) of the Malaise trap is generally useful for large, fasterflying members of the Diapriinae (even better for Belytinae). The plastic head is replaced by a screened compartment and insects are collected below in a plastic bag (Whirl-Pak) filled with $70 \%$ ethanol. The screen of the head compartment is treated with pyrethroid and the top covered by a transparent rain deflector. For long-term trapping, with long intervals in servicing, a plastic tube is attached below the screened compartment, ending in a large underground container. Propylene glycol is recommended as a preservative.

Separation bag (Masner and Gibson, 1979). We used this tool primarily for sampling newly explored habitats prior to use of other mass-collecting tools (e.g., screen sweeping). It remains useful for quick evaluations of collecting sites.

Beating sheet. A modification of the standard beating sheet with a screen ( $5 \mathrm{~mm}$ openings) and a narrow terminal sleeve is practical for surveying spiny bushes (e.g., hawthorns, acacia, or roses), especially in desert habitats.

Light trap (with excluder). A blacklight tube suspended over a container with water and detergent is placed inside a cage with wire mesh or netting with $5 \mathrm{~mm}$ openings to eliminate masses of large nocturnal insects. The sleeve on the tube is treated with pyrethroid. This type of trapping eliminates most of the nontarget biomass and requires no servicing during nighttime. The best results are in areas of high incidence and diversity of army ants, generally lowland tropical areas.

Ant nests. Diapriine wasps, particularly in the Nearctic region, can be collected individually on the underside of rocks covering ant nests. Morning hours seem best with regard to optimal temperatures of the rock. Myrmecophilic diapriines of Central and South America may be collected individually (e.g., from raids) as well as in groups (e.g., emigration columns of army ants).

Emergence traps. A pyramidal cage of dense mesh fabric is suspended over target microhabitats or a pile of organic material (duff, fungi, presifted litter, wood stumps); composts with decaying plant materials are particularly productive for diapriine wasps. The top of the pyramid is treated with pyrethroid. A large plastic container filled with water and detergent is placed on top of the pile directly below the top of the pyramid.

Sifting. Sifted organic matter (duff, rotted wood, kelp, etc.) is spread on white plastic sheets, and specimens are collected in aspirators. Larger amounts of sifted material can be placed in Berlese apparatus or xereclector.

Some of the above techniques, screen sweeping in particular, will result in an unusually high number of specimens being caught. For rapid retrieval of target groups the following tools and procedures were developed and used successfully. To prevent coagulation of proteins around the mouth and anus in specimens from traps filled with brine, the material must be thoroughly yet gently rinsed in fresh water prior to storage in alcohol. Clean material is then segregated into three fractions by using sorting sifters made of wire mesh $(0.5 \mathrm{~cm}, 0.3 \mathrm{~cm}$, and 0.1 $\mathrm{cm})$. The material is successfully rinsed-sifted in $70 \%$ ethyl-alcohol through each of the three sifters $(0.5 \mathrm{~cm} \rightarrow 0.3 \mathrm{~cm} \rightarrow 0.1 \mathrm{~cm})$; microhymenoptera will remain almost entirely in the finest fraction. The fractions are subsequently examined under a stereomicro- 
scope $(40 \times)$ in a rectangular sorting dish, longitudinally divided into six columns by raised ridges. The targetculled specimens are briefly rinsed in a special strong detergent (e.g., Cascade) to remove oily substances and dirt accumulated on the body, the hairy parts in particular. Clean specimens are either further processed, mounted directly from alcohol, or stored in $70 \%$ ethanol in a dark, refrigerated area.

The aspects of clean specimens and proper mounting cannot be overemphasized. In fact, the importance of properly prepared specimens is second only to the availability of material per se. Recognition of closely related species often depends on minute details of microsculpture and pilosity. Even a small amount of dirt or a film of oil on minute wasps can obscure relevant structures and hinder the taxonomist's decision. Dry mounting on points is strongly preferred to mounting on rectangular cards. The latter method better protects the specimen, but makes examination of particular areas of the body, such as the venter, difficult. Making slides is necessary for detailed examination of genitalia, palpal and tibial formulae, antennal sensilla, and microtrichia on the wings.

Considering the minute body size of a typical diapriine wasp, only high quality stereomicroscopes using the highest magnification available (ca. 160 $\times$ ) are recommended. A strong source of light in combination with a properly operated light disperser (Mylar) is indispensable for creating a clear, glare-free image. The ever increasing use of scanning electron microscopes (SEM) for the study of microsculpture is essential in diapriine taxonomy. For best results in SEM photography, gold coating specimens with a gold sputter and back-scattering device is highly recommended. Instant (Polaroid) SEM prints can be used for examination of ultrastructures as well as for subsequent tracings for line drawings.

\section{STRUCTURE OF KEYS, DIAGNOSES, AND DESCRIPTIONS}

We prepared a key using simple, nonesoteric terms; all morphological terms are defined in the Glossary (p. 12-15), and most of them are also illustrated. We avoided us- ing character states requiring dissection, slide making or use of expensive technology (e.g., SEM) not currently available in some countries. We also minimized the use of subjective expressions (e.g., "usually", "often", "rarely", etc.); however, in both the diagnoses and descriptions the use of such expressions is unavoidable, if not desirable, in order to express the frequency of a given character state in a given genus. Complicated couplets (e.g., conditional states) were also avoided; when necessary, a large polytypic genus was split into uniform groups and presented several times in the key. The structure of the key does not reflect the putative relationships among the genera. It reflects the taxonomic limits of New World diapriine genera; consequently, we do not recommend the use of the key outside the New World. The generic diagnosis attempts to give a brief, salient portrait of a given genus. Elements of diagnosis are then repeated in the generic description, with details of the known spectrum of character states. The generic description is at first centered around the main core of the genus, then, continuing centrifugally toward peripheral species, includes all undescribed species studied by us. Internal groupings (species groups) of the genus may be further discussed in the Recognition and Relationships section. The sections on Distribution and Biology are intended to give principal information without claiming to be complete references.

\section{HIGHER CLASSIFICATION AND INTERRELATIONSHIPS}

The Diapriinae is one of the four subfamilies of the Diapriidae (Masner, 1976; Masner in Goulet and Huber, 1993). It is the most advanced of the above four subfamilies, characterized by morphological reductions, especially in the wing venation and structure of the antenna. However, from the cladistic point of view, the Diapriinae appear, at least by our present knowledge, as a paraphyletic group. Whereas all three subfamilies, Belytinae, Ambositrinae, and Ismarinae, can each be defined by at least one synapomorphy, Diapriinae can be separated strictly on simple morphological reductions; therefore, the 
proper cladistic evaluation of the Diapriinae remains a challenge for future taxonomists.

The classification of the Diapriinae at tribal level has received little attention, especially in the New World. Ashmead (1893) proposed two tribes: Spilomicrini and Diapriini. Regrettably, the concepts of these two tribes were highly heterogeneous, and we use the two names in considerably restricted sense. Outside North America the tribal classification of the Diapriinae was attempted by Hellén (1963) and Kozlov (1978). We recognize Hellén's tribe Psilini, but treat his tribe Paramesiini as a junior synonym of Spilomicrini Ashmead 1893. Kozlov's five tribes contain the three tribes of Hellén plus two new tribes not represented in the New World.

This paper is not aimed at a higher (suprageneric) classification of Diapriinae. For convenience we accepted three tribes proposed previously, i.e., the Psilini, the Spilomicrini, and the Diapriini, to accommodate the 52 genera that are presently recognized. Three genera, Caecopria Masner, Calogalesus Kieffer, and Peckidium, new genus, are treated as incertae sedis because they obviously do not belong to any of the three recognized tribes. In our opinion they represent three independent tribes; similarly, the genera Basalys Westwood and Doliopria Kieffer, presently included in the Diapriini, in our opinion represent an independent tribe. However, the formal reclassification of the Diapriinae at tribal level is best deferred until all genera of the world are taken into consideration. Finally, we call attention to the fact that two genera traditionally placed in the Diapriinae-Aneurhynchus Westwood and Labolips Haliday-are not included in the Diapriinae; Masner (in Goulet and Huber, 1993) pointed out that both belong to the subfamily Belytinae because of the longitudinal grooves on S2 of the metasoma.

Two main lineages may be recognized within the Diapriinae: the Psilini and the Spilomicrini plus Diapriini. The Psilini retain the macrotergite 2 (T2 only) of the metasoma and exposed sclerotized labrum, synapomorphies with the Belytinae, used here as an outgroup for all other Diapriinae. The synapomorphies for the Psilini are the type of wing venation (submarginal vein not reaching foremargin) and the long, spikelike spiracle 1 on the side of the pronotum. The members of the Spilomicrini and the Diapriini all share large syntergite 2 of the metasoma, with T2 and T3 fused. The Spilomicrini are characterized by the length of the submarginal vein together with the marginal vein reaching well past the basal third of the forewing, and the presence (ground plan) of the notauli. The Diapriini are the most derived of all tribes; the short submarginal vein closely approximated to anterior margin of forewing, the lack of notauli, and the ground plan of antennal formula (12-14) are the principal synapomorphies.

\section{RECOMMENDED BASIC WORKS}

Several major publications are essential for taxonomic study of the New World Diapriinae. Johnson's (1992) catalog lists all species of the world. De Santis cataloged diapriines of Argentina (1967) and Brazil (1980). Masner (in Hanson and Gauld, 1995) treated the Diapriinae of Costa Rica. Muesebeck and Walkley (1956) list type species of diapriine genera. Masner and Muesebeck (1968) provide information on primary types of diapriine wasps in the USNM. Kieffer's (1916) treatise of the world Diapriidae remains the only key to the world taxa. Ashmead's (1893) monograph of North American proctrupoid wasps is largely of historical value.

\section{TAXONOMIC LIST OF DIAPRIINAE GENERA DESCRIBED}

\section{TRIBE PSILINI}

Aneuropria Kieffer

Coptera Say

Ortona, new genus

Psilus Panzer

\section{TRIBE SPILOMICRINI}

Bruchopria Kieffer

Chilomicrus, new genus

Doddius, new genus

Entomacis Foerster

Epomium, new genus

Ferrugenus, new genus

Idiotypa Foerster

Paramesius Westwood

Pentapria Kieffer

Poecilopsilus Ogloblin 
Spilomicrus Westwood

Xenismarus Ogloblin

\section{TRIBE DIAPRIINI}

Acanthopria Ashmead

Apopria, new genus

Asolenopsia Kieffer

Auxopaedeutes Brues

Avoca, new genus

Basalys Westwood

Bruesopria Wing

Cruzium, new genus

Diapria Latreille

Doliopria Kieffer

Ecitovagus Masner

Eladio, new genus

Hansona, new genus

Labidopria Wasmann

Leucopria, new genus

Megaplastopria Ashmead

Mimopria Holmgren

Mimopriella, new genus

Mitropria Ogloblin

Monelata Foerster

Myrmecopria Ashmead

Neivapria Borgmeier

Notoxoides Ashmead

Omopria, new genus

Philolestoides Ferrière

Platymischus Westwood

Psychopria, new genus

Szelenyiopria Fabritius

Szelenyisca Masner

Townesella Huggert and Masner

Trichopria Ashmead

Turripria, new genus

Xanthopria Brues

UNPLACED GENERA (incertae sedis)

Caecopria Masner

Calogalesus Kieffer

Peckidium, new genus

\section{DISTRIBUTION (table 1)}

The geographic area covered in this paper encompasses the entire New World, i.e., both the Nearctic and Neotropical regions. In more vernacular terms, the New World means the Canadian Arctic and Alaska down to the Patagonian subregion in Argentina and Chile. We are well aware of the enormity of this task, and therefore present this treatise only as a prologue for future exploration.
Vast areas of the hemisphere remain insufficiently explored or totally untouched. Even the presumed centers of diapriine diversity (e.g., Valdivian/Patagonian subregion, High Andes) are barely in the initial stage of exploration. Faunal exploration of the New World can progress on two fronts. One is in the use of versatile tools of mass collecting (e.g., Malaise trap, large numbers of yellow pan traps, flight interception trap, screen sweeping, car net), especially in areas of presumed species diversity of diapriine wasps. The other way to progress is in focusing on specific microhabitats that cannot be effectively sampled by conventional collecting techniques. Two special microhabitats that appear to be particularly rich for diapriine wasps throughout the entire Neotropical region are ant nests and aquatic or semiaquatic habitats. Unusually large numbers of diapriine wasps became associated with various groups of ants in Central and South America. The associations are especially well developed with army ants (Ecitonini) and leafcutting ants (Attini), with some 20 genera of Diapriinae already involved. Modified light traps with net excluders (see Collection and Preparation of Specimens, p. 6) are a major source of field data. Diapriine wasps in aquatic or semiaquatic microhabitats are virtually unstudied; the genus Psychopria described in this paper with only one species is now represented in CNCI by an additional 20 undescribed species. All Psychopria species were collected by yellow pan traps placed directly in the stream beds, while no individuals were ever collected in Malaise traps placed along the same streams.

Of the 52 genera of New World Diapriinae, 26 occur in Nearctic and 45 in Neotropical regions, respectively; nineteen genera, almost all speciose, are shared by the above two geographic regions. However, at the species level, even with very preliminary data available, the Neotropical fauna is infinitely richer than that of America north of Mexico.

\section{NeARCTIC REGION}

The 26 genera of Nearctic North American Diapriinae can be divided by their geographic relationships into three categories: Holarc- 
TABLE 1

New World Distribution of Diapriinae Genera

\begin{tabular}{|c|c|c|c|c|c|c|}
\hline & Nearctic & Mexico & $\begin{array}{l}\text { Central } \\
\text { America }\end{array}$ & Antilles & $\begin{array}{l}\text { South } \\
\text { America }\end{array}$ & $\begin{array}{l}\text { Valdivian } \\
\text { Patagonian }\end{array}$ \\
\hline Acanthopria & $\mathrm{X}$ & $\mathrm{X}$ & $\mathrm{X}$ & $\mathrm{X}$ & $\mathrm{x}$ & \\
\hline Aneuropria & $\mathrm{x}$ & & & & & \\
\hline Apopria & $\mathrm{X}$ & & & & & \\
\hline Asolenopsia & & & $\mathrm{X}$ & & $\mathrm{X}$ & \\
\hline Auxopaedeutes & $\mathrm{X}$ & $\mathrm{X}$ & & $\mathrm{x}$ & & \\
\hline Avoca & $\mathrm{x}$ & $\mathrm{X}$ & & $\mathrm{x}$ & $\mathrm{X}$ & \\
\hline Basalys & $\mathrm{x}$ & $\mathrm{X}$ & $\mathrm{X}$ & $\mathrm{X}$ & $\mathrm{x}$ & \\
\hline Bruchopria & & & & & $\mathrm{X}$ & \\
\hline Bruesopria & $\mathrm{X}$ & & & & & \\
\hline Caecopria & & $\mathrm{X}$ & $\mathrm{X}$ & $\mathrm{X}$ & $\mathrm{X}$ & \\
\hline Calogalesus & & & & $\mathrm{X}$ & & \\
\hline Chilomicrus & & & & & & $\mathrm{X}$ \\
\hline Coptera & $\mathrm{X}$ & $\mathrm{X}$ & $\mathrm{X}$ & $\mathrm{X}$ & $\mathrm{x}$ & \\
\hline Cruzium & & & $\mathrm{X}$ & & $\mathrm{X}$ & \\
\hline Diapria & $\mathrm{X}$ & & & & & $\mathrm{X}$ \\
\hline Doddius & & $\mathrm{X}$ & $\mathrm{X}$ & & $\mathrm{X}$ & $\mathrm{x}$ \\
\hline Doliopria & $\mathrm{X}$ & $\mathrm{X}$ & $\mathrm{X}$ & $\mathrm{X}$ & $\mathrm{x}$ & \\
\hline Ecitovagus & $\mathrm{x}$ & $\mathrm{X}$ & $\mathrm{X}$ & & & \\
\hline Eladio & & & $\mathrm{x}$ & & $\mathrm{X}$ & \\
\hline Entomacis & $\mathrm{X}$ & $\mathrm{X}$ & $\mathrm{X}$ & $\mathrm{X}$ & $\mathrm{x}$ & $\mathrm{X}$ \\
\hline Epomium & & & & & & $\mathrm{x}$ \\
\hline Ferrugenus & & & & & & $\mathrm{x}$ \\
\hline Hansona & & & $\mathrm{x}$ & & $\mathrm{x}$ & \\
\hline Idiotypa & $\mathrm{X}$ & $\mathrm{X}$ & $\mathrm{x}$ & $\mathrm{X}$ & $\mathrm{x}$ & $\mathrm{X}$ \\
\hline Labidopria & $\mathrm{X}$ & $\mathrm{X}$ & $\mathrm{X}$ & & $\mathrm{x}$ & \\
\hline Leucopria & $\mathrm{X}$ & $\mathrm{X}$ & $\mathrm{X}$ & & $\mathrm{x}$ & \\
\hline Megaplastopria & & $\mathrm{X}$ & $\mathrm{X}$ & $\mathrm{x}$ & $\mathrm{x}$ & \\
\hline Mimopria & & & & & $\mathrm{X}$ & \\
\hline Mimopriella & & & $\mathrm{X}$ & & $\mathrm{X}$ & \\
\hline Mitropria & & & & & $\mathrm{X}$ & \\
\hline Monelata & $\mathrm{X}$ & $\mathrm{X}$ & $\mathrm{X}$ & $\mathrm{X}$ & $\mathrm{X}$ & \\
\hline Myrmecopria & $\mathrm{X}$ & & & & & \\
\hline Neivapria & & & & & $\mathrm{X}$ & \\
\hline Notoxoides & & & & & $\mathrm{X}$ & \\
\hline Omopria & & & & & $\mathrm{X}$ & \\
\hline Ortona & $\mathrm{X}$ & & $\mathrm{X}$ & & $\mathrm{X}$ & \\
\hline Paramesius & $\mathrm{x}$ & $\mathrm{X}$ & $\mathrm{x}$ & $\mathrm{X}$ & $\mathrm{x}$ & $\mathrm{X}$ \\
\hline Philolestoides & & & & & $\mathrm{x}$ & \\
\hline Peckidium & & & $\mathrm{x}$ & $\mathrm{X}$ & $\mathrm{x}$ & \\
\hline Pentapria & $\mathrm{X}$ & $\mathrm{X}$ & $\mathrm{X}$ & $\mathrm{X}$ & $\mathrm{x}$ & $\mathrm{X}$ \\
\hline Platymischus & $\mathrm{x}$ & & & & & \\
\hline Poecilopsilus & & & & & & $\mathrm{X}$ \\
\hline Psilus & $\mathrm{X}$ & & & & & \\
\hline Psychopria & $\mathrm{X}$ & $\mathrm{X}$ & $\mathrm{X}$ & $\mathrm{X}$ & $\mathrm{X}$ & \\
\hline Spilomicrus & $\mathrm{X}$ & $\mathrm{X}$ & $\mathrm{X}$ & $\mathrm{X}$ & $\mathrm{X}$ & $\mathrm{X}$ \\
\hline Szelenyiopria & & & $\mathrm{X}$ & & $\mathrm{x}$ & \\
\hline Szelenyisca & & & $\mathrm{X}$ & & $\mathrm{X}$ & \\
\hline Townesella & $\mathrm{X}$ & & & & & \\
\hline Trichopria & $\mathrm{X}$ & $\mathrm{X}$ & $\mathrm{X}$ & $\mathrm{X}$ & $\mathrm{X}$ & \\
\hline Turripria & & & $\mathrm{X}$ & & $\mathrm{x}$ & \\
\hline Xanthopria & & & & & $\mathrm{X}$ & \\
\hline Xenismarus & & & & & & $\mathrm{X}$ \\
\hline
\end{tabular}


tic (12 genera), Neotropical extensions (9 genera), and Nearctic endemics (5 genera).

1. Holarctic. The 12 genera involved share strong relationships with both western and eastern Palearctic fauna; nine genera (Basalys, Coptera, Entomacis, Idiotypa, Monelata, Paramesius, Psilus, Spilomicrus, and Trichopria) are medium to highly speciose and most of them are also worldwide in distribution. Three genera (Aneuropria, Diapria, and Platymischus) are monotypic or with only few species. Diapriinae seem to be poorly represented in extreme northern zones of North America; Entomacis sp. is the only known diapriine wasp in the high Arctic of Canada (Ellesmere Is.) (CNCI). The Hudsonian and boreal zones harbor only a very small fauna of Diapriinae; similarly, high elevations in the Rockies have only a few species. The above small segment of Nearctic Diapriinae appears most closely related to Palearctic fauna, with some species possibly shared between the two regions. The transitional zone of North America holds the most of species, with only very few species shared with the Palearctic region.

2. Neotropical extensions. The mutual proliferation of Nearctic and Neotropical faunas is encountered in and along the entire Mexican border in the lower austral zone, USA. Nine genera belong to this category: Acanthopria, Avoca, Doliopria, Ecitovagus, Labidopria, Leucopria, Ortona, Pentapria, and Psychopria. Acanthopria and Doliopria are particularly speciose in the Neotropical region, but are not represented outside the New World.

3. Nearctic endemic genera. Five genera, all small in content or monotypic, belong to this group; all members are known or supposed to be associated with ants (Apopria, Auxopaedeutes, Bruesopria, Myrmecopria, and Townesella). There are two very distinct subgroups in this category (Huggert and Masner, 1983); Auxopaedeutes and Bruesopria, associated with thief ants (Solenopsis, subgenus Diplorhoptrum) are related to $\mathrm{Pa}$ learctic genera Solenopsia Wasmann and Lepidopria Kieffer, both also associates of Solenopsis ants. Apopria and Myrmecopria are associated with army ants (Neivamyrmex) and are related to the extended Neotropical faunal elements (Ecitovagus, Labidopria).
Townesella, presumably, is related to Labidopria.

\section{NeOtropicAl REgion}

The 45 genera of Diapriinae in the Neotropical region form 5 geographic subregions (Mexico, Antilles, Central America, South America, and Valdivian/Patagonian) most of which seem to be more sharply delimited than the corresponding subregions of the $\mathrm{Ne}$ arctic region.

1. Mexico. This area covers Mexico from the US border to the isthmus of Tehuantepec. Twenty genera (Acanthopria, Auxopaedeutes, Avoca, Basalys, Caecopria, Coptera, Doddius, Doliopria, Ecitovagus, Entomacis, Idiotypa, Labidopria, Leucopria, Megaplastopria, Monelata, Paramesius, Pentapria, Psychopria, Spilomicrus, and Trichopria) are recorded from Mexico but none are peculiar to it. The fauna is a typical mixture of $\mathrm{Ne}$ arctic and Neotropical fauna; Nearctic elements proliferate deeply south along the central mountains and Neotropical elements extend along the Atlantic and Pacific coasts and northwards.

2. Central America. This area covers the Mexican state of Chiapas south to Panama. With 28 genera (Acanthopria, Asolenopsia, Basalys, Caecopria, Coptera, Cruzium, Doddius, Doliopria, Ecitovagus, Eladio, Entomacis, Hansona, Idiotypa, Labidopria, Leucopria, Megaplastopria, Mimopriella, Monelata, Ortona, Paramesius, Peckidium, Pentapria, Psychopria, Spilomicrus, Szelenyiopria, Szelenyisca, Trichopria, and Turripria) including virtually all speciose ones, this subregion is second only to South America. The two subregions are closely related faunally (at species-group level) and many widespread species are shared, especially along coastlines both in the Caribbean and Pacific. There are no genera peculiar to Central America.

3. Antilles. This area covers the Greater and Lesser Antilles minus Trinidad. With only 18 genera (Acanthopria, Auxopaedeutes, Avoca, Basalys, Caecopria, Calogalesus, Coptera, Doliopria, Entomacis, Idiotypa, Megaplastopria, Monelata, Paramesius, Peckidium, Pentapria, Psychopria, Spilomicrus, and Trichopria), and no endemics this 
subregion is generally depauperate. Most conspicuously missing are all Neotropical genera of Diapriinae associated with army ants (Ecitonini), but some speciose Neotropical genera are also not represented. The overall species diversity of some larger genera is rather low in the Antilles (e.g., Trichopria, Coptera, and Spilomicrus). The single record of Calogalesus (Lesser Antilles) most probably accounts for a "tramp" species.

4. South America. We include here the Caribbean coast of Colombia, Venezuela, the Guyanas, Trinidad, Amazon basin, Pantanal (Paraguay, Argentina) and the Andes from Colombia to Peru and Galapagos Islands. The maximum of 36 genera (Acanthopria, Asolenopsia, Avoca, Basalys, Bruchopria, Caecopria, Coptera, Cruzium, Doddius, Doliopria, Eladio, Entomacis, Hansona, Idiotypa, Labidopria, Leucopria, Megaplastopria, Mimopria, Mimopriella, Mitropria, Monelata, Neivapria, Notoxoides, Omopria, Ortona, Paramesius, Philolestoides, Peckidium, Pentapria, Psychopria, Spilomicrus, Szelenyiopria, Szelenyisca, Trichopria, Turripria, and Xanthopria) makes the South American subregion the richest and simultaneously the most diverse in the New World. In particular, the genera of Diapriinae associated with ants reach the highest levels of diversity. The High Andes are notable for the northward proliferation of southern temperate faunal elements.

5. Valdivian/Patagonian. This subregion comprises most of southern Chile (including Juan Fernandez Island) and the Argentinian province Nunquen (including the Falkland Islands) with temperate to cool-temperate forests and grasslands. There are relatively few faunal connections to the rest of the Neotropics but endemism is high and some distinct Gondwanic ties to New Zealand, Australia, and (rarely) South Africa. Only 11 genera ((Chilomicrus, Doddius, Entomacis, Epomium, Ferrugenus, Idiotypa, Paramesius, Pentapria, Poecilopsilus, Spilomicrus, and Xenismarus), with 5 genera endemic (Chilomicrus, Epomium, Ferrugenus, Poecilopsilus, and Xenismarus)) are recorded from this subregion. The records of Diapria from Chile probably represent a tramp species. However, the number and frequency of species in any habitat of this subregion is truly remarkable. Together with the Belytinae and Ambositrinae, Diapriinae is the dominant group among all microhymenoptera in this part of the New World. Conversely, the genera of many New World Diapriinae, including some speciose ones, are remarkably absent here. The Valdivian/Patagonian subregion appears to be an important center of evolution, having predominately archaic or plesiomorphic taxa of Diapriinae.

\section{GLOSSARY OF TERMS}

Morphological terms, with their abbreviations, are those basically used by Masner (1991). Several new terms or character states previously not used in the taxonomy of the Diapriidae are marked with an asterisk (*). Instructions on measurements follow the definition of each term where applicable.

\section{HEAD}

Antennal shelf (as)—Projecting ledge between face (fc) and frons (fr) and bearing toruli (tr); in dorsal and lateral views.

Clypeus (cl)-Divided from face by epistomal declivity (ed) and in some species by tentorial pits (tp); ventral margin of clypeus may be slightly pointed medially or, usually, truncate; measure in frontal view.

Epistomal declivity (ed)-Shallow, arched depression on upper margin of clypeus (cl), usually rudimentary; in frontal view.

Eye height (eh)-Maximum distance between upper eye orbit (ueo) and lower (leo) eye orbit; measure in lateral view.

Eye height/malar space- Ratio; both measurements in frontal view.

Head height $(\mathrm{HH})$-Maximum distance between imaginary line connecting top of ocelli and lower edge of closed mandibles (md); measure in lateral view. Note: In some species head attains maximum height in this particular position; measurements taken at a different angle will result in smaller, incorrect measurements.

Head length (HL) - Maximum distance between anterior edge of antennal shelf (as) and extreme posterior edge of occipital flange (of); measure in lateral view.

Head width (HW) - The maximum distance between outer margins of eye orbits (oeo) (most species) or between margins of bulging temples (te) (few species; in dorsal view).

*Hypostomal bridge-Space between base of maxilla and foramen magnum; in ventral view. 
*Labrum-Narrow sclerite between clypeus and mandible; in frontal view.

Malar sulcus (ms)_-Sulcus connecting lowermost arc of eye orbit (leo) with upper corner of mandibular condyle (mc); in frontal view.

Mandible (md)-For proper observation of teeth, mandibles must be fully open; in frontal view.

Occipital flange (of)_-Steplike rim on occiput; in lateral view.

*Oral carina-bladelike carina on ventral side of head flanking maxilla; in lateral view.

Postgena (pg)_Part of head between posterior margin of eye orbit (peo) and occiput, above cheek; in lateral view.

Postgenal cushion (pgc)-Cushion of hairs on postgena (pg); in lateral view.

Temple (te)_Portion of head behind eye; temples are termed receding (converging), parallel, or bulging according to their shape in dorsal view. Note: Head must be perfectly horizontal, i.e., antennal shelf (as) visible; in dorsal view.

Tentorial pit (tp)_-Pair of pits marking dorsolateral corners of clypeus (cl) on epistomal declivity (ed), in most species reduced or absent; in frontal view.

Torulus (tr) (pl. toruli)—Antennal socket.

\section{Antenna}

*A1 flaps-Pair of lamellae at apex of A1, flanking base of A2 (e.g., fig. 55a).

Antennal clava (acl, $q)-$ Several distal antennomeres, usually incrassate and shaped differently from preceding segments. To determine the beginning of clava, the clavomeres must be viewed ventrally where they are (most species) flattened and bear special granular sculpture; to determine the profile of the clava, the shape of apical clavomere in particular, the clava must be viewed laterally with ventral, flattened side perfectly horizontal.

Antennal formula-Total number of antennomeres in female antenna (first number) and male antenna (second number), excluding radicle, e.g., antennal formula 12-14 in Coptera.

Antennomeres, relative proportions ( 9 $₫)-\mathrm{Max}-$ imum length and width of antennomeres; measure width in dorsal view (especially in female clava).

Apical clavomere ventral pit $(q)$-Shallow depression (circular or transverse) on ventral side of apical clavomere; view at angle of $45^{\circ}$ for best shadow effect.

Radicle-Connective joint between A1 and torulus; radicle not included in count for antennal formula.

Sex segment (ð) —-Specialized antennomere, typically A4 (rarely A3), usually constricted ba- sally and bearing sharp keel on outer surface; in lateral view.

* Specialized brushes ( $\widehat{0}$ )—Row of short, semierect or erect hairs on ventral sides of male A7$\mathrm{A} 8$, or $\mathrm{A} 8-\mathrm{A} 9, \mathrm{~A} 8-\mathrm{A} 10$, or $\mathrm{A} 8$ only; view in light beamed below antenna on white background.

\section{Mesosoma (dorsal view-msd)}

Anterior parallel line (apl)_-Pair of elevated longitudinal lines on anteromedian part of mesoscutum (msc); in some species the lines are only weakly developed and should be observed obliquely $\left(45^{\circ}\right.$ angle); synonym-admedian line.

Anterior scutellar pit (asp)_-Pit or pits on anterior margin of scutellum (SC) immediately behind transscutal articulation (tsa); pits are separated by a septum of various widths.

Axilla (ax)—Paired areas on mesonotum laterad scutellum (SC).

*Axillar depression (ad)_-Paired large depressions laterad scutellar disc (sd), often filled with hairs or foamy structures.

*Axillar pit (ap)_Central pit on axilla (ax).

Cervix (ce)_-Anterior necklike part of pronotum; in dorsal and lateral views.

Dorsellum (ds)-Median part of metanotum (mtn); usually with three short, longitudinal keels.

*Epicnemial carina-Subvertical carina behind and above epicnemial pit (ep); in lateral view.

*Epicnemial pit (ep)_-Pit or depression, often with dense pilosity in anteroventral corner of mesopleuron (mpl), behind forecoxa (cx1); in lateral view.

Humeral sulcus (hs)_Longitudinal impression in postero-lateral corner of mesoscutum (msc), mediad of tegula ( $\mathrm{tg}$ ).

Lateral scutellar keel (lsk)_-Pair of keels (usually rims) on each side of scutellar disc (sd).

Lateral scutellar pit (1sp)_-Pair of narrow-elongate pits situated along posterolateral margin of scutellum (SC); view obliquely $\left(45^{\circ}\right.$ angle) in some species.

Mesosoma length (ML)_Maximum length measured between anterior margin of cervix (ce) and posterior margin or corners of propodeum.

Mesosoma width (MW)-Maximum width across mesoscutum (msc) between outer margins of tegulae (tg).

Notaulus (nt)_-Pair of longitudinal grooves on mesoscutum (msc); often abbreviated anteriorly, in some species reduced to small pits situated in front of transscutal articulation (tsa); in older literature incorrectly termed "parapsidal furrows". 
Nucha (nu)_Posteromedian projection of propodeum housing articulation with petiolar condyle.

Parapsidal line (ppl)_-Pair of shallow lines on posterior half of mesoscutum ( $\mathrm{msc}$ ), between notaulus (nt) and humeral sulcus (hs).

*Plica (pl)_-Paired longitudinal keels (plicae) flanking median keel (mpk) on propodeum.

Posterior scutellar pits ( $\mathrm{psp}$ )-Transverse row of minute pits along posterior margin of scutellum (SC).

Pronotal cushion (pc)-Cushion of pilosity in the cervical part of pronotum (pnt); in dorsal and lateral views.

Pronotal shoulders-Pair of prominent humps (rounded or pointed) on anterior sides of pronotum; in dorsal view.

Propleuron-Narrow sclerite between forecoxa (cx1) and foramen magnum capitis; in ventral view.

Scutellum (SC)-Sclerite on mesonotum between mesoscutum (msc) and metanotum ( $\mathrm{mtn})$.

Scutellar disc (sd)_-Part of scutellum (SC) between anterior scutellar pits (asp) and posterior scutellar pits (psp).

Suprahumeral sulcus-Longitudinal impression in anterolateral part of mesoscutum (msc) above humeral sulcus (hs).

Tegula ( $\operatorname{tg}$ ) - Sclerite at base of forewing.

Transscutal articulation (tsa)_Line dividing mesoscutum (msc) from scutellum (SC); line vestigial or absent in short-winged or wingless species; synonym, "transscutal suture".

\section{Mesosoma (lateral view-msl)}

Epomium (em)_Elevated margin of an oblique carina on side of pronotum (pnt).

Forecoxa (cx1)_-Basal segment of foreleg.

Hind coxa (cx3)_Basal segment of hind leg.

*Median oblique line-Submedian oblique depression on mesopleuron (mpl) between forecoxa (cxl) and posterolateral corner of mesopleuron (mpl).

Median propodeal keel (mpk)-Median, longitudinal keel on propodeum, usually well elevated, especially in its anterior part.

Mesopleuron ( $\mathrm{mpl}$ )-Sclerite between fore (cx1) and mid (cx2) coxae.

Mesosoma height ( $\mathrm{MH}$ )_Maximum height measured vertically between highest point of scutal convexity and lowermost convexity of mesopleuron (mpl).

Metapleuron (mtp)-Sclerite above hind coxa (cx3).

Mid coxa (cx2)_-Basal segment of mid leg.

Pronotal side (pnt)—side of pronotum.

*Spiracle 1 ( $\mathrm{sp} 1)$-Spiracle on pronotal side (pnt).
* Spiracle 2 (sp2)_-Spiracle on propodeum.

Sternaulus (stn)-Transverse ridge or keel (rarely sulcus) on lower mesopleuron ( $\mathrm{mpl}$ ), between fore (cx1) and mid (cx2) coxae.

\section{FOREWING (w)}

Basal vein (bv) - Nebulous (rarely tubular) transverse vein between submarginal vein (sv, i.e., $\mathrm{Sc}+\mathrm{R})$ and $\mathrm{M}+\mathrm{Cu} 1$.

Costal cell-Space between costal (C) and submarginal veins (sv).

Costal vein-Vein between tegula (tg) and marginal vein $(\mathrm{mv})$; examine in transparent light (vein often absent).

Medial vein (M) -Nebulous vein distad basal vein (bv).

Marginal cilia (mc)—Series of hairs on periphery of wing.

Marginal vein (mv)_-Tubular vein on foremargin of wing.

$\mathrm{M}+\mathrm{Cu} 1-$ Nebulous vein parallel to posterior margin of wing.

Postmarginal vein (pmv)_-Tubular apex of marginal vein $(\mathrm{mv})$.

Rs2-Nebulous vein anterior to stigmal vein (sv).

Rs3-Nebulous vein posterior to stigmal vein (sv).

Stigmal vein (stv) - Tubular projection on lower corner of marginal vein $(\mathrm{mv})$.

Submarginal vein (sv) (i.e., Sc $+\mathrm{R}$ )-Tubular vein between tegula ( $\mathrm{tg}$ ) and marginal vein (mv).

\section{Metasoma}

Cercus (pl. cerci)_-Pair of appendages on T9.

*Macrotergite-Single, large tergite (T2) past petiole.

Metasoma height (MTH)_Maximum height measured between top of T2 (or syntergite) and bottom of $\mathrm{S} 2$; in lateral view.

Metasoma width (MTW)-Maximum width measured across T2 (or syntergite); in dorsal view.

Metasoma past petiole (width/height)_-Maximum width (MTW) measured across the large tergite (dorsal view), height (MTH); in lateral view.

Petiole (pet)-First metasomal segment with fused tergite 1 (T1) and sternite 1 (S1).

Spiracle 3 (sp3)-Spiracle on T8.

Sternite 2 (S2), pilosity-Cushion of dense hairs at base of $\mathrm{S} 2$; in ventral view.

* Sternite 2 (S2), specialized spot-Internal circular or subcircular object (? glandular function) near anterior margin of $\mathrm{S} 2$, transparent through the sclerite; ventral or $45^{\circ}$ oblique view or metasoma detached.

*Syntergite-Large tergite past petiole resulting from fusion of several tergites (e.g., T2 + T3). 
Tergite 2, pilosity-Paired tufts of hairs at anterior margin of $\mathrm{T} 2$.

\section{KEY TO DIAPRIINAE GENERA IN THE NEW WORLD}

1. Notaulus present, deeply incised, complete or abbreviate anteriorly, rarely reduced to small pit near transscutal articulation ....

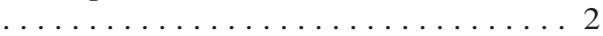

- Notaulus entirely absent, rarely mesoscutum with shallow depressions in notaular region

2(1). Ocellar triangle situated distinctly in front of ocular zone (fig. 82); pronotum medially (including cervix) as long as mesoscutum; metasoma past petiole with very short trapezoidal tergite (fig. 82, arrow) followed by large tergite (minute, $1 \mathrm{~mm}$ long; forms with very long marginal cilia on wings); Neotropical .... ... Peckidium, new genus 9 (p. 117)

Ocellar triangle situated in or slightly behind ocular zone (ocelli absent in some short-winged or wingless species); pronotum medially (including cervix) distinctly shorter than mesoscutum; metasoma past petiole beginning with very large tergite ............. 3

3(2). Forewing appearing veinless, submarginal vein either glassy, depigmented, not reaching foremargin of wing (fig. 89), or venation rudimentary or entirely absent (figs. 37, 79); no short-winged forms known ............... 4

- Forewing with pigmented submarginal vein terminating in marginal vein on foremargin of wing (e.g., fig. 97); stigmal and other veins often developed (e.g., fig. 60); short-winged or wingless forms occur .............. 6

4(3). Frons between eyes with sharp projections, points, or ledges (figs. 37, 89); A1 relatively short, apical rim with sharp flaps (figs. 37, 89); mandibles strongly projecting, beaklike (figs. 37, 89); antennal formula $12-14 \ldots \ldots \ldots \ldots \ldots$

- $\quad$ Frons between eyes unarmed (figs. 78, 79); A1 distinctly elongate, apical rim rounded, without flaps (fig. 79); mandibles not projecting, clasped (fig. 79); antennal formula 11-13; Nearctic (Arizona), Central and South America ........ ...... Ortona, new genus + ot (p. 34)

5(4). Forewing with glassy, depigmented submarginal vein (fig. 89), apical emargination and median fold not developed; occiput rounded, not steplike (fig. 89); male A3 distinctly shorter than A4; Nearctic .... Psilus Panzer of o (p. 37)

Forewing at most with rudiment of glassy depigmented submarginal vein (fig. 37), apical emargination and median fold present (all $q$ and some $\delta$ ) (fig. 37), or absent (some $\hat{0}$ ); occiput sharply angular, steplike (fig. 37); male A3 subequal to A4 in length; Nearctic and Neotropical ........ Coptera Say $q$ o (p. 33)

6(3). Frons armed with sharp points above eyes or near ocelli (figs. 30, 31, 34); mandibles strongly projecting, beaklike (figs. $29,31,34) \ldots \ldots \ldots \ldots \ldots \ldots$

- $\quad$ Frons unarmed; mandibles not projecting, clasped ............... 8

7(6). Basal vein in forewing strongly pigmented, slanting toward base of marginal vein (fig. 31); metasoma past petiole distinctly wider than high; body often densely pubescent; Neotropical .... . . Caecopria Masner ô (part) (p. 113)

Basal vein in forewing absent (fig. 34); metasoma past petiole strongly compressed, higher than wide; body almost glabrous; Antilles ............. .... Calogalesus Kieffer of 0 (p. 116)

8(6). Anterior margin of syntergite straight, without median notch or emargination (fig. 88) ............... 9

- Anterior margin of syntergite notched or slit medially and/or laterally, or margin broadly excavate, concave (e.g., figs. 33, $39,49,59) \ldots \ldots \ldots \ldots \ldots \ldots 11$

9(8). Notaulus remarkably crenulate (fig. 88); female antenna nonclavate (anterior scutellar pit single, large; dorsellum with long fingerlike process [fig. 87]); Valdivian

... Poecilopsilus Ogloblin $\oint^{\widehat{\alpha}}$ (p. 56)

- Notaulus not crenulate; female antenna distinctly clavate (figs. 81, 97) . . . 10

10(9). Female A13 moderately to distinctly longer than A12 (fig. 81); male A3 distinctly shorter than A4; anterior scutellar pit variable in shape, only exceptionally bifoveate; Nearctic and Neotropical ................. ... Paramesius Westwood $q \hat{o}$ (part)

(p. 52)

- $\quad$ Female A13 at most equal in length to A12, often shorter (fig. 97); male A3 at least as long as A4, often longer; anterior scutellar pit always bifoveate; Nearctic and Neotropical .. Spilomicrus Westwood + o (part) (p. 57)

11(8). Antenna 12- or 14-segmented .... 12 - Antenna 13-segmented ... . . . . . . 14 
12(11). Antenna 12-segmented, clava massive, multisegmented but nonabrupt (fig. 60); postmarginal vein in forewing moderately developed (fig. 60); anterior scutellar pit usually tripartite (fig. 59); body often light colored, reddish brown to yellow; short-winged or wingless forms occur; Nearctic and Neotropical ..............

. . Idiotypa Foerster $q$ (part) (p. 51)

- Antenna 14-segmented ( $q$ $\left.\delta^{\top}\right) \ldots . . .13$

13(12). Basal vein in forewing perfectly perpendicular to submarginal vein (fig. 32); stigmal vein short, obtuse-angled to marginal vein; female antenna with nonabrupt clava, clavomeres subquadrate; labrum not exposed; Valdivian ...... Chilomicrus, new genus 웅

(p. 40)

- Basal vein in forewing moderately arcuate, acute-angled to submarginal vein (fig. 101); stigmal vein distinctly elongate, almost perpendicular to marginal vein; female antenna with light, nonabrupt clava, clavomeres beadlike (fig. 101); labrum exposed; Valdivian ...............

. . Xenismarus Ogloblin $\overbrace{}^{\widehat{o}}$ (p. 59)

14(11). Marginal vein in forewing remarkably long, 3.3-5.5 times as long as stigmal vein (fig. 40); cheek with fan of striae reaching lower orbit of eye (fig. 40); petiole remarkably elongate, subequal in length to or longer than rest of metasoma; mesosoma and petiole often with rough rugulose sculpture; no short-winged forms known; Central and South America ........... ... Doddius, new genus $q$ के (p. 43)

- Marginal vein in forewing at most 3 times longer than stigmal vein, usually shorter; cheek typically nonstriate, very rarely with short fan in lower part, striae never reaching lower orbit (short-winged forms occur) .... 15

15(14). Stigmal vein in forewing distinctly elongate, usually subequal in length or longer than marginal vein (figs. 48, $50)$; apex of forewing often subtruncate (fig. 50) to emarginate-cordate; anterior scutellar pit single, large and deep (fig. 49), very rarely with few longitudinal keels on bottom; Nearctic and Neotropical ............. .... Entomacis Foerster o t (p. 44)

Stigmal vein in forewing short, shorter than marginal vein (figs. 53, 56, 60,
$81,85)$; apex of forewing rounded . . $\ldots \ldots \ldots \ldots \ldots \ldots$

16(15). Female apical sternite large, conical, longer than three preceding sternites (fig. 81); male A3 distinctly shorter than A4; marginal vein in forewing distinctly longer than stigmal vein (fig. 81); Nearctic and Neotropical . .

. Paramesius Westwood $q \hat{\sigma}$ (part)

(p. 52)

- Female apical sternite smaller, shorter than three preceding sternites (figs. $53,56)$; male A3 subequal to or longer than A4; marginal vein in forewing usually shortened (figs. 60, 85), less frequently longer than stigmal vein (figs. 53, 56) . . . . . . 17

17(16). Hind wing with closed basal cell (figs. $53,56)$; anterior scutellar pit bifoveate, foveae often obscured by rough sculpture; epomium always strongly developed (figs. 53, 56) . . . . 18

Hind wing without closed basal cell (figs. 60, 85); anterior scutellar pit trifoveate (fig. 59) or pit replaced by arc of small crenulae (fig. 86); epomium only rarely developed ....... 19

18(17). Apical rim of A1 not excavate ventrally, rim not produced in flaps (fig. 55b); clypeus distinctly wider than long, anterior margin not flexed; cheek not striate (fig. 56); Valdivian ....... ..... Ferrugenus, new genus $q \delta$

(p. 48)

- $\quad$ Apical rim of A1 deeply excavate ventrally, rim produced in flaps (e.g., fig. 55a); clypeus slightly elongate, with anterior margin projecting and flexed; cheek often with short fan of striae (fig. 53); Valdivian ...........

Epomium, new genus ot ơ (p. 46)

19(17). Median keel of propodeum strongly developed, pointed, point often directed backward (fig. 60); postmarginal vein in forewing moderately to distinctly developed (fig. 60); basal vein in forewing nonarcuate, slanted at acute angle toward submarginal vein (fig. 60); body often light colored; Nearctic and Neotropical ..............

. . Idiotypa Foerster ô (part) (p. 51)

Median keel of propodeum only moderately developed, rudimentary, or absent (fig. 85), very rarely pointed; postmarginal vein in forewing rudimentary; basal vein in forewing moderately to strongly arcuate (fig. 85); body usually blackish; Nearctic and 
Neotropical .............. ..... Pentapria Kieffer $ᄋ$ ô (part) (p. 54)

20(1). Antenna 13-segmented ......... 21

- Antenna with different number of segments ................ 29

21(20). Wings stumplike, usually not reaching past petiole, veins reduced or absent, or wings entirely absent ..... 22

Wings fully developed, usually reaching or surpassing tip of metasoma, typically marginal and submarginal veins present ............. 24

22(21). Anterior margin of large syntergite straight, not notched, emarginate, or excavate; Nearctic and Neotropical

.. Spilomicrus Westwood 우 đิ (part)

(p. 57)

- $\quad$ Anterior margin of syntergite notched, emarginate, or excavate ..... 23

23(22). Body light colored, orange to yellow; female antennal clava abruptly 3 -segmented; Valdivian ............. ... ? Idiotypa Foerster ơ $q$ (part) (p. 52)

- $\quad$ Body dark, blackish; female antennal clava nonabrupt; Neotropical .... ..... Pentapria Kieffer + o (part) (p. 54)

24(21). Submarginal vein in forewing closely approximated to foremargin of wing, i.e., costal cell almost absent (fig. 69); anterior scutellar pit absent; female A13 massive, ovoid (fig. 69); petiole and propodeum entirely carpeted with dense pale pilosity; Nearctic and Neotropical ..... Monelata Foerster $q$ (part) (p. 93)

- $\quad$ Submarginal vein in forewing distinctly remote from foremargin of wing, i.e., costal cell at least as wide as submarginal vein (figs. 50, 81) . . . . 25

25(24). Female A13 moderately to distinctly larger than A12 (fig. 81); male A3 distinctly shorter than A4; marginal vein in forewing distinctly longer than stigmal vein; Nearctic and Neotropical .... Paramesius Westwood $q \widehat{\sigma}$ (part) (p. 52)

- $\quad$ Female A13 subequal to A12 in size or even smaller; male A3 subequal in length to A4 or even longer; marginal vein in forewing subequal in length to stigmal vein, rarely only slightly longer .............. 26

26(25). Anterior scutellar pit absent (fig. 24); pronotum sharply raised dorsomedially (fig. 23); propodeum and petiole densely carpeted with minute velvety hairs; South America .......... ... Bruchopria Kieffer $q$ ơ (p. 39)

Anterior scutellar pit present (1 or 2 pits) ............. 27

27(26). Stigmal vein in forewing distinctly elongate (fig. 50); anterior margin of syntergite notched or excavate, often also flexed (fig. 49); apex of forewing often subtruncate to emarginate-cordate; Nearctic and Neotropical ....... ... Entomacis Foerster $q$ ô (part)

(p. 44)

- $\quad$ Stigmal vein in forewing short (e.g., fig. 97); anterior margin of syntergite not notched or excavate, never flexed; apex of forewing rounded ..... 28

28(27). Anterior scutellar pit bifoveate; basal vein in forewing often present (nebulous); frons unarmed; Nearctic and Neotropical ...............

. . Spilomicrus Westwood o to (part)

(p. 57)

- $\quad$ Anterior scutellar pit single; basal vein in forewing absent; frons with two sharp points and transverse ledge (fig. 67); South America ........... .... Mitropria Ogloblin ơ (part) (p. 92)

29(20). Wings stumplike, usually not reaching past petiole, veins reduced or absent, or wings not developed ...... 30

- Wings fully developed, usually reaching or surpassing tip of metasoma, typically submarginal and marginal veins present ............ 50

30(29). Head distinctly opisthognathous (fig. 29); frons armed with sharp point above eye; eye reduced to single ommatidium or rarely entirely absent; head and mesosoma usually with granular sculpture or large dense punctures; Neotropical .......... .... Caecopria Masner ot ơ (part)

(p. 113)

- Head normal, hypognathous ..... 31

31(30). Anterior margin of syntergite modified, notched medially, or sometimes flexed (e.g., fig. 59); Neotropical and Valdivian ..... Idiotypa Foerster 우 (part) (p. 51);? Idiotypa (Valdivian spp.) (p. 52)

- Anterior margin of syntergite not modified, not flexed, without notch (e.g., figs. $8,12,51,70) \ldots \ldots 32$

32(31). All tarsi moderately to strongly compressed, higher than wide (figs. 58, 72, 76); legs unusually long and large, 
hind tibia typically with constriction only at extreme base (figs. 52, 58, 66, $72,76)$; body rather large $(2-6 \mathrm{~mm})$, often with sculpture, specialized setae, and/or light colors, ferrugineous to yellow; specialized associates of various ants .......... 33

All tarsi cylindrical, almost as high as wide; legs normal to short and stout, hind tibia typically constricted in anterior half; body rather small (ca. 1 $\mathrm{mm}$ ), always smooth, dark, rarely with specialized setae or light colored; terricolous or rarely associates of ants ............. 44

33(32). Antenna 11-segmented . . . . . . . 34

- Antenna 12-segmented . . . . . . 37

34(33). Pronotum anteromedially (not at pronotal shoulders) produced into truncate process (fig. 74); metasternum (between mid and hind coxae) produced into forked furca (fig. 76, arrow); South America ............. .... Notoxoides Ashmead $q$ (part) (p. 97)

- $\quad$ Pronotum not produced anteromedially (pronotal shoulders sometimes widened); metasternum unarmed ... 35

35(34). Vertex remarkably elevated and topped up (fig. 100); pronotum with distinct patch of rugosity in epomial area; female antenna 11-segmented; mesopleuron often with fine horizontal striae; Central and South America ..... . .... Turripria, new genus $q$ (part) (p. 110)

- $\quad$ Vertex normally arched (figs. 13, 72) ................ 36

36(35). Frontal depression sharply margined posterad (with midpoint) and laterad (bulge above eye) (figs. 70, 72); inner apices of fore and mid tibiae sharply projecting (fig. 71); eye small, subcircular (fig. 72); Nearctic (southeastern USA)

... Myrmecopria Ashmead $q$ (part) (p. 94)

- $\quad$ Frontal depression unmargined, without midpoint or tori above eyes; apices of fore and mid tibiae not projecting; eye large, inverted, droplike (fig. 13); Central and South America ...... ......Asolenopsia Kieffer $q$ (part) (p. 65)

37(33). Median keel of propodeum moderately to strongly raised; propodeum rather short and steeply sloping (figs. 10, 11, $13,84) \ldots \ldots \ldots \ldots \ldots \ldots$
- Median keel of propodeum at most weakly raised anteriorly, typically very low or entirely absent; propodeum moderately to distinctly elongate, only moderately sloping or subhorizontal (figs. 9, 52, 73) . . . 39

38(37). Frontal depression sharply margined posterad (with midpoint) and laterad (bulge above eye) (fig. 84); South America ................

. Philolestoides Ferrière $q$ (p. 101) Frontal depression unmargined, without point or tori (fig. 13); Central and South America ..... Asolenopsia Kieffer o (part) (p. 65)

39(37). Eye absent (fig. 9); tibial spurs absent; palpi absent; fore and middle basitarsi ventrally projecting into strong spines (fig. 9); dorsellum strongly developed; Nearctic (Florida) ......... .... Apopria, new genus $q$ (p. 63) Eye, tibial spurs, and palpi present; fore and middle basitarsi not projecting ventrally; dorsellum relatively short ............... 40

40(39). S2 with dense brush of hairs medially (fig. 73); temple and postgena with rough rugulose keel (fig. 73); epomium bladelike projecting; South America ................. .... Neivapria Borgmeier ㅇ (p. 96) S2 without tuft of hairs; temple and postgena without keel; epomium absent ............4 41

41(40). Mesoscutum strongly humped anteromedially (figs. 51, 52); posterior part of propodeum constricted-elongate, causing impression of 2-segmented petiole (figs. 51, 52); Nearctic and Central America ............ .... Ecitovagus Masner $q$ ô (part) (p. 77)

- Mesoscutum not humped anteromedially (figs. 58, 64, 66); propodeum of different shape ..........442

42(41). Metasoma past petiole short, subglobular; syntergite in lateral view remarkably convex (fig. 58); smaller members $1.5-2.5 \mathrm{~mm}$ long; Nearctic, Central and South America ......... ... Labidopria Wasmann $q$ (part) (p. 83)

Metasoma past petiole moderately elongate, ovoid; syntergite in lateral view only moderately convex (figs. 64, 66); larger members, $3.5-5.5 \mathrm{~mm}$ long .. 
43(42). Frons with moderate to distinct projections medially (point) and laterally (bulge above eye) (figs. 65, 66); metasternum posterior of mid coxa not excavate (fig. 66); head and mesosoma predominantly to entirely sculptured; South America .......... . . Mimopria Holmgren of 0 (part) (p. 89)

Frons without projections (fig. 64); metasternum posterior of midcoxa deeply excavate (fig. 64); head and mesosoma predominantly smooth; Central and South America ...........

Mimopriella, new genus + ò (part) (p. 90)

44(32). Petiole produced fingerlike dorsally above anterior margin of syntergite (fig. 25); female antenna usually 11segmented, with abrupt 3-segmented clava; propodeum strongly constricted anteriorly, moderately to distinctly excavate posteriorly (fig. 26); Nearctic ...... Bruesopria Wing 9 o (part)

$$
\text { (p. 72) }
$$

- $\quad$ Petiole subcylindrical, as long as wide or slightly elongate, not produced above syntergite ........4 45

45(44). Propodeum deeply excavate posteromedially, lateral sides horseshoe-like (figs. 6, 16) $\ldots \ldots \ldots \ldots \ldots 46$

Propodeum not excavate posteromedially, lateral sides not horseshoe-like ................ 47

46(45). Head distinctly elongate (figs. 6, 7); mandibles falcate, opisthognathous; tergites after large tergite (T2 only) extremely short, compressed (fig. 6); Nearctic (California) ........... ... Aneuropria Kieffer of ơ (p. 31) Head subglobose (fig. 17); mandibles clasped, hypognathous; tergites after syntergite $(\mathrm{T} 2+\mathrm{T} 3)$ wide and not compressed (fig. 19); Nearctic, Mexico,? Antilles ...... Auxopaedeutes Brues $q$ ot (part) (p. 67)

47(45). Female antenna 11-segmented, A10 and A11 remarkably enlarged (fig. 44); area of propodeum between median keel and plica almost glabrous; $\mathrm{Ne}$ arctic and Neotropical .......... . . . . . Doliopria Kieffer $^{\dagger}$ (part) (p. 76)

- $\quad$ Female antenna 12-segmented . . . 48 48(47). Head in dorsal and lateral view distinctly elongate; eye small and projecting (fig. 90); male A1 swollen, sex segment on A3 (fig. 91); male forebasi- tarsus expanded distally; Nearctic (Holarctic) ................ .... . Platymischus Westwood $q \delta$ (p. 102)

- Head in dorsal and lateral view more or less globular; eye sometimes small but not projecting; male A1 normal, cylindrical, sex segment on A4; male forebasitarsus normal, not expanded ................. 449

49(48). Female antenna with abrupt 3- or 4-segmented clava (fig. 22); area of propodeum between median keel and plica almost glabrous; Nearctic and Neo-

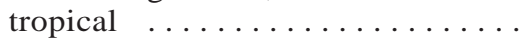
.... Basalys Westwood + ơ (part) (p. 70)

- Female antenna with nonabrupt clava (fig. 99); area of propodeum between median keel and plica hairy; Nearctic and Neotropical .............

... Trichopria Ashmead o to (part)

(p. 108)

50(29). Submarginal vein in forewing remote from foremargin of wing by at least its own diameter (figs. 22, 44; better seen in anterior half of vein); marginal vein reaching past basal third of wing length ............ 51

- Submarginal vein in forewing closely approximated to foremargin of wing, almost appearing contiguous (figs. 64, 99); marginal vein reaching only before basal third of wing length .. 53

51(50). Forewing with basal vein (fig. 22); female antenna 12-segmented; Nearctic and Neotropical ............. .... Basalys Westwood + ô (part) (p. 70)

- $\quad$ Forewing without basal vein; female antenna 11-segmented ........ 52

52(51). Frons with two sharp points and transverse ledge (fig. 67); female antenna with abrupt 3-segmented clava; South

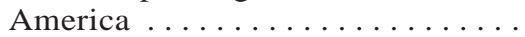
.... Mitropria Ogloblin + (part) (p. 92)

- Frons unarmed or very rarely with 1 median point; female antenna A10 and A11 distinctly enlarged, clava strong but nonabrupt (fig. 44); Nearctic and Neotropical ..... Doliopria

Kieffer $+\underset{0}{o}$ (part) (p. 76)

53(50). A2 inserted on A1 distinctly below apex (fig. 95); female antenna 11-segmented; vertex highly topped above eye (fig. 95); South America ........ .... Szelenyisca Masner $q$ (p. 106) 
- $\quad$ A2 inserted at apex of A1 . . . . 54

54(53). Vertex remarkably elevated (fig. 100); pronotum with distinct patch of rugulosity in epomial area; female antenna 11-segmented; mesopleuron often with fine horizontal striae; Central and South America ........... .... Turripria, new genus ${ }^{\circ}$ (part) (p. 110)

- Vertex not elevated, normally arched (figs. 58, 61, 64, 98) ....... 55

55(54). All tarsi moderately to strongly compressed, higher than wide (figs. 58, $66,72,76)$; head and mesosoma often with sculpture and specialized setae; all specialized associates of various ants ............ 56

All tarsi more or less cylindrical, as high as wide; head and mesosoma only rarely sculptured, usually smooth and shining, only very rarely with specialized setae; mostly free-living species, rarely associated with ants .... $\ldots \ldots \ldots \ldots 66$

56(55). Frontal depression sharply margined, with midpoint and/or lateral bulge above eye (figs. 52, 65, 72, 74, 84) $\ldots \ldots \ldots \ldots \ldots 57$

- Frontal depression not margined, without midpoint or bulge above eye (figs. $13,58,61,64,73,98) \ldots \ldots 1$

57(56). Pronotum anteromedially (not shoulders!) produced into truncate process (fig. 76); metasternum (between mid and hind coxae) produced into forked furca (fig. 76, arrow); South America ... Notoxoides Ashmead $q \hat{\sigma}$ (part) (p. 97)

- $\quad$ Pronotum not produced anteromedially (shoulders sometimes widened); metasternum unarmed ........58

58(57). Mesoscutum strongly humped anteromedially (fig. 51); posterior part of propodeum constricted, elongate, causing impression of 2-segmented petiole (figs. 51, 52); Nearctic and Central America ............ .... Ecitovagus Masner ㅇํ ơ (part) (p. 77)

- Mesoscutum normally arched anteromedially (figs. 66, 72, 84); propodeum of different shape ...... 59

59(58). Inner apices of fore and mid tibiae produced into strong spines (fig. 71); mid and hind tibiae with only single rudimentary spur; female antenna 11segmented; Nearctic (southeastern USA $\ldots \ldots \ldots \ldots \ldots \ldots \ldots$
Myrmecopria Ashmead $q$ to (part)

(p. 94)

- Inner apices of fore and mid tibiae unarmed; mid and hind tibiae with 2 normal spurs; female antenna 12-segmented .............660

60(59). Propodeum remarkably short, steeply sloping down, with moderate to strong median keel (fig. 84); body with fine, tapered hairs; South America ................... ... Philolestoides Ferrière $q$ (part) (p. 101)

Propodeum distinctly elongate, subhorizontal (fig. 66), median keel absent or at most rudimentary; body with strong bristles, bristles often truncate apically; South America ........ ... Mimopria Holmgren $q$ ơ (part) (p. 89)

61(56). S2 with large tuft of hairs at meson (fig. 73); epomium sharp, bladelike; postgena with rough rugulose keel; South America ... Neivapria Borgmeier $q$ (part) (p. 96)

- S2 without tuft of hairs; epomium usually not developed; postgena smooth or coriaceous, very rarely with minute keel ...............66 62

62(61). Median keel of propodeum moderately to strongly developed (figs. 11, 61,

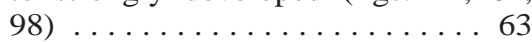

- Median keel of propodeum at most rudimentary anteromedially (figs. 58,

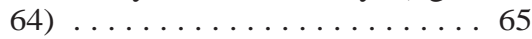

63(62). Median keel of propodeum produced anteromedially into long fingerlike process, usually curved backward (fig. 61); apex of female metasoma with extensive whitish or yellowish area; male A3-A13 either with 2 moderate knots and whorls of bristles or with randomly scattered hairs; Central and South America ......

Leucopria, new genus $q$ ơ (p. 85)

Median keel of propodeum not produced into long fingerlike process (figs. 11, 98); apex of female metasoma without light spot; male (Asolenopsia gibba) A4-A14 with one whorl of bristles ......... 64

64(63). Eye in lateral view moderately to distinctly higher than long, almost inverted, droplike (fig. 13); head in lateral view slightly higher than long; hairy cushions and/or foamy structures occur; Central and South America $\ldots \ldots \ldots \ldots \ldots \ldots . . \ldots$ 
.... Asolenopsia Kieffer $\oint^{\hat{t}}$ (part)

(p. 65)

- $\quad$ Eye in lateral view subcircular (fig. 98); head in lateral view subglobular; hairy cushions and foamy structure not developed; Nearctic (Sonora) ...

Townesella Huggert and Masner $q$ (p. 107)

65(62). Propodeum in lateral view moderately to distinctly elongate, often subhorizontal dorsally (fig. 64); hind femur only slightly compressed anteriorly (dorsal view); metasternum anteriorly (posterior of mesocoxa) with deep semicircular cleft (fig. 64); Central and South America .. Mimopriella, new genus $+\sigma^{\dagger}$ (part) (p. 90)

Propodeum in lateral view short, distinctly sloping down (fig. 58); hind femur remarkably compressed anteriorly (dorsal view); metasternum anteriorly only rarely with shallow invagination; Nearctic, Central and South America .. Labidopria Wasmann 9 (part) (p. 83)

66(55). Face or entire head (often also mesoscutum or syntergite) with dense, fine, semiappressed pilosity (figs. 93, 94); antennal shelf between toruli not developed, space rounded; distance between toruli larger than or subequal to distance between torulus and inner orbit (fig. 93); frenal gutter of forewing sharply angular (fig. 94); female antenna 11-segmented; aquatic in habits; Neartic and Neotropical .. Psychopria, new genus 우 ô (p. 103)

Face or other parts of body glabrous or with only a few scattered long hairs or bristles; antennal shelf between toruli sharp, carinate; distance between toruli subequal to or shorter than distance between torulus and inner orbit; frenal gutter of forewing not angular; female antenna predominantly 12segmented; only a few aquatic species ................6 67

67(66). Petiole large, robust, swollen vaseshaped, smooth and glabrous dorsally (fig. 36); female apical sternite with massive carpet of stiff yellowish pegs (fig. 35); legs remarkably short and strong, middle and hind basitarsi shortened (fig. 36); Central and South America ... Cruzium, new genus $q$

Petiole of different shape, usually smaller, sculptured and/or hairy; female apical sternite without carpet of pegs ...............6 68

68(67). Scutellar disc distinctly concave at meson, with lateral keels raised; female antenna without clava, A4-A11 almost beadlike (fig. 20); axillar depression, metanotum, and propodeum with long dense pilosity dorsally); Nearctic (Florida), Antilles (Jamaica), Central America ............. ...... Avoca, new genus $q$ (p. 69)

- Scutellar disc flattened or even convex and/or keeled at meson, lateral keels not raised . . . . . . . . . . 69

69(68). Petiole in lateral view remarkably higher than wide, fingerlike projection produced dorsally above anterior margin on syntergite (fig. 25); propodeum strongly constricted anteriorly (fig. 26); female antenna with abrupt 3segmented clava; Nearctic ......

...... Bruesopria Wing $q$ o (Part)

(p. 72)

- $\quad$ Petiole in lateral view leveled with or below anterior margin of syntergite; propodeum not constricted anteriorly ............... 70

70(69). Propodeum deeply excavate posteromedially almost to posterior margin of dorsellum, i.e., median part and keel absent, sides horseshoe-like (fig. 16); small-sized individuals, about 1 $\mathrm{mm}$, light to dark brown, legs short and stout; Nearctic, Mexico,? Antilles ... Auxopaedeutes Brues of to (part)

(p. 67)

- Propodeum posteromedially at most moderately concave, median part and keel usually well developed, sides not horseshoe-like .......... 71

71(70). Occiput with short upright spine posteromedially (fig. 62); A1 with fine to distinct longitudinal keels, apical rim bladelike sharp, often spinelike; median keel of propodeum long, pointed backward (fig. 62); male A3-A14 with fine irregular sculpture and long scattered nonwhorled hairs); Central and South America ... Megaplastopria Ashmead of ô (p. 87)

- Occiput unarmed; A1 without longitudinal keels and with rounded apical $\operatorname{rim} \ldots \ldots \ldots \ldots \ldots . \ldots 72$

72(71). Petiole and propodeum entirely carpeted with dense pale pilosity obscuring surface (figs. 68, 69); minute, gracile members, around $1 \mathrm{~mm}$ long; anterior scutellar pit absent (fig. 68); male A4 
not modified; Nearctic and Neotropi-

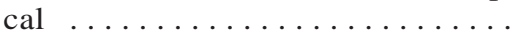

Monelata Foerster ơ (part) (p. 93)

Petiole and propodeum at most sparsely hairy, with surface well visible 73

73(72). Pronotal shoulders strongly developed, with sharply flexed edges (fig. 77); body with scattered straight strong setae truncate apically; female antenna 12-segmented, male A3-A13 with scattered nonwhorled hairs; South America .................

. . Omopria, new genus ơ ô (p. 99)

Pronotal shoulders at most moderately developed, not flexed, distinctly rounded ............. 74

74(73). Body with scattered nail-like straight setae, setae truncate apically; body robust; female antenna 11-segmented, in one species 12-segmented; male A3-A13 with one whorl of bristles; sides of propodeum posterolaterally strongly projecting (fig. 96); Central and South America ........... ...... Szelenyiopria Fabritius o o (p. 105)

Body without scattered naillike setae, setae appressed or tapered apically . . .................. 75

75(74). Apex of foretibia dorsally produced into slightly curved spine ....... 76 Apex of foretibia unarmed dorsally ... $\ldots \ldots \ldots \ldots \ldots \ldots 77$

76(75). Anterior margin of syntergite moderately to distinctly flexed and notched medially; female clava subpentamerous (fig. 38); male A3 with longitudinal keel; Nearctic (D. conica [Fabricius], cosmopolitan $) \ldots \ldots \ldots \ldots \ldots$. . . .

. . . . Diapria Latreille $q$ ơ (p. 75)

Anterior margin of syntergite straight, not flexed, without notch; female clava usually with less than 5 segments (fig. 99); male A3 without keel; Nearctic and Neotropical ..........

... Trichopria Ashmead o ơ (part)

(p. 108)

77(75). Female antenna 11-segmented; male A3-A13 with scattered nonwhorled hairs, A3 and A4 clearly separated

$\ldots \ldots \ldots \ldots \ldots \ldots$

Female antenna 12-segmented; male A3-A13 with one whorl of long bristles, A3 and A4 fused (figs. 1, 2) ...

............... 79

78(77). Forewing with distinct marginal cilia; female A11 remarkably enlarged, forming 1-segmented clava (fig. 57); no deep cleft between mandibles and clypeus; Central and South America

- Hansona, new genus of ơ (p. 81) Forewing without marginal cilia; female A11 not markedly wider than preceding clavomeres (fig. 102); deep cleft between mandibles and clypeus (fig. 102); South America ........... ..... Xanthopria Brues $q$ (p. 112)

79(77). Hind tibia along inner side with dense brush of setae (fig. 46); median keel of propodeum moderately to distinctly spatulate, flattened dorsally (figs. 45, 47); entire body sculptured, netlike reticulate or finely matte (fig. 45); Central and South America ......... .... Eladio, new genus o ô (p. 79) Hind tibia at most with fine row of setae; median keel of propodeum not spatulate, usually pointed-curved backward (fig. 5) or nearly absent, body usually smooth and shining, very rarely partly rugulose, never netlike reticulate or matte; Nearctic (Arizona, Texas), Neotropical ...... Acanthopria Ashmead $q$ to (p. 61)

\section{CLAVE PARA LA SEPARACIÓN DE LOS GÉNEROS DE DIAPRIINAE DEL NUEVO MUNDO}

1. Notaulus presente, profundo, completo o rudimentario anteriormente, raras veces reducido a pequeña puntura próxima a la articulación tansescutal ............ 2

- Notaulus completamente ausente, mesoescuto raras veces con depresiones muy leves en la región del notaulus .......... 20

2(1). Triángulo ocelar claramente ubicado delante de la zona ocular (fig. 82); pronoto medialmente (incluyendo el cervix) tan largo como el mesoescuto; metasoma después del pecíolo con un tergito trapezoidal muy corto (fig. 82, flecha) seguido por otro gran tergito (diminutos, 1 $\mathrm{mm}$ de longitud, ala con cilias marginales muy largas); Neotropical ...... .. Peckidium, genero nuevo $q$ (p. 117) Triángulo ocelar ubicado en la zona ocular o ligeramente detrás de ella (ocelos ausentes en algunas especies ápteras o braquipteras); pronoto medialmente (incluyendo el cervix) claramente más corto que el mesoescuto; primer tergito del metasoma después del peciolo muy desarrollado ................ 3 
3(2). Ala anterior aparentemente sin venas, vena submarginal transparente, sin pigmentación, no alcanza el margen anterior del ala (fig. 89), o con venación rudimentaria o completamente ausente (figs. 37, 79); no se conocen especies con alas reducidas o ápteras ...........4 4

Ala anterior con la vena submarginal pigmentada, alcanzando el margen anterior del ala a nivel de la vena marginal (p.ej., fig. 97); vena estigmal y otras venas frecuentemente desarrolladas (p.ej., fig. $60)$; pueden encontrarse especies de alas reducidas o ápteras .........6 6

4(3). Frente con proyecciones agudas, puntas o carenas (figs. 37, 89); A1 relativamente corto, borde apical con láminas agudas (figs. 78, 79); mandíbulas proyectándose fuertemente hacia atrás, en forma de pico (figs. 37, 89); fórmula antenal 12$14 \ldots \ldots \ldots \ldots \ldots \ldots$

Frente sin proyecciones (figs. 78, 79); A1 marcadamente alargado, borde apical redondeado, sin láminas (fig. 79); mandíbulas no proyectadas posteriormente, cerradas sobre sí mismas (fig. 79), fórmula antenal 11-13; Neártica (Arizona), Centro y Sur América ........... ... Ortona, genero nuevo qồ (p. 34)

5(4). Ala anterior con la vena submarginal despigmentada, de apariencia vidriosa (fig. 89), emarginación apical y pliege medio ausente; occipucio redondeado (fig. 89); A3 en los machos claramente más corto que A4; Neártica .............. ........ Psilus Panzer 우 ơ (p. 37) Ala anterior sólo con rudimentos despigmentados de la vena submarginal (fig. 37), emarginación apical y pliege medio presentes (en todos los $q$ y en algunos §) (fig. 37), o ausentes (en algunos §ో); occipucio marcadamente angular (fig. 37); A3 en los machos similar en longitud a A4; Neártica y Neotropical ...

Coptera Say ơ ơ (p. 33)

6(3). Frente armada con agudos salientes sobre los ojos o cerca a los ocelos (figs. 30, 31, 34); mandíbulas proyectándose fuertemente hacia atrás, en forma de pico (figs. 29, 31, 34) . . . . . . . . 7

- Frente lisa, mandíbulas sin proyectarse hacia atrás, cerradas sobre sí mismas .... $\ldots \ldots \ldots \ldots \ldots$

7(6). Vena basal del ala anterior fuertemente pigmentada, dirigiéndose hacia la base de la vena marginal (fig. 31); metasoma después del pecíolo claramente más ancho que alto; cuerpo frecuentemente con pubescencia densa; Neotropical ....

Caecopria Masner ô (parte) (p. 113)

- Vena basal del ala anterior ausente (fig. 34); metasoma después del pecíolo fuertemente comprimido, más alto que ancho; cuerpo casi glabro; Antillas ...

.... Calogalesus Kieffer + $\delta$ (p. 116)

8(6). Margen anterior del sintergito recto, medialmente sin incisión o emarginación (p.ej., fig. 88) .............9

- Margen anterior del sintergito medialmente o lateralmente con incisiones o ampliamente excavado o cóncavo (figs. $33,39,49,59) \quad \ldots \ldots \ldots \ldots \ldots 11$

9(8). Notaulus marcadamente crenulado (fig. 88); antena de la hembra sin clava; fosa escutelar anterior simple, muy desarrollada; dorsellum con un largo proceso digitiforme (fig. 87); Valdiviana .... .. . Poecilopsilus Ogloblin $q$ ô (p. 56)

- Notaulus no crenulado; antena de la hembra clavada (figs. 81, 97) . . . . . 10

10(9). A13 en la hembra moderadamente o claramente más largo que A12 (fig. 81); A3 en el macho claramente más corto que A4; fosa escutelar anterior de forma variable, solo excepcionalmente bifoveada o dividida; Neártica y Neo-

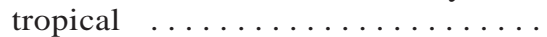

. Paramesius Westwood $q$ o (parte)

(p. 52)

- A13 en la hembra al menos igual en longitud a $\mathrm{A} 12$, frecuentemente más corto (fig. 97); A3 en el macho al menos tan largo como A4, frecuentemente más largo; fosa escutelar anterior siempre bifoveada; Neártica y Neotropical . . . Spilomicrus Westwood + ๙ิ (parte) (p. 57)

11(8). Antena con 12 o 14 segmentos ... 12 - Antena con 13 segmentos ........ 14 12(11). Antena con 12 segmentos, clava muy desarrollada, multisegmentada, pero nunca abrupta (fig. 60); ala anterior con la vena postmarginal moderadamente desarrollada (fig. 60); fosa escutelar anterior usualmente dividida en tres partes (fig. 59); cuerpo generalmente de coloración clara, desde marrón rojizo a amarillo; existen formas con alas reducidas o sin ellas; Neártica y Neotropical ......... Idiotypa Foerster $q$ (parte) (p. 51)

- $\quad$ Antena con $14 \operatorname{segmentos}\left(\begin{array}{ll}q & \widehat{\delta}\end{array}\right) \ldots$.

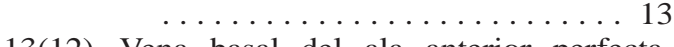

13(12). Vena basal del ala anterior perfectamente perpendicular a la vena submarginal (fig. 32); vena estigmal cor- 
ta, formando un angulo obtuso con la vena marginal; antena de la hembra con clava gradual, clavómeros subcuadrados; labro no expuesto; Valdiviana ................

.... Chilomicrus, genero nuevo 9 ơ

- Vena basal del ala anterior moderadamente arqueada, formando un ángulo agudo con la vena submarginal (fig. 101); vena estigmal claramente alargada, casi perpendicular a la vena marginal; antena de la hembra con clava poco manifiesta, gradual, clavómeros semiesféricos (fig. 101); labro expuesto; Valdiviana .........

. . Xenismarus Ogloblin of ơ (p. 59)

14(11). Vena marginal del ala anterior notablemente larga, de 3.3 a 5.5 veces más larga que la estigmal (fig. 40); mejilla con una serie de estrias en forma de abanico que alcanzan el margen inferior del ojo (fig. 40); pecíolo sumamente largo, similar en longitud al largo del resto del metasoma; mesosoma y pecíolo frecuentemente con escultura rugulosa muy fuerte; no se conocen formas con alas reducidas; Centro y Sur América ...........

Doddius, genero nuevo우 ơ (p. 43)

Vena marginal del ala anterior como máximo 3veces el largo de la vena estigmal, usualmente más corta; mejilla típicamente sin estrías, en raras ocasiones un pequeño abanico en la parte inferior, pero nunca llegan a alcanzar el margen inferior del ojo (pueden existir formas con alas reducidas) $\ldots .$. ............... 15

15(14). Vena estigmal del ala anterior claramente alargada, usualmente subigual en longitud o más larga que la vena marginal (figs. 48, 50); ápice del ala anterior frecuentemente subtruncado o emarginado (fig. 50); fosa escutelar anterior no dividida, bien desarrollada y profunda (fig. 49), muy raramente con algunas quillas longitudinales en el fondo; Neártica y Neotropical ... . . . . . Entomacis Foerster $q$ ô (parte)

(p. 44)

- Vena estigmal del ala anterior corta, más corta que la vena marginal (figs. 53, $56,60,81,85)$; ápice del ala anterior redondeado .......... 16

16(15). Esternito apical de la hembra muy desarrollado, cónico, más largo que 3 esternitos precedentes (fig. 81); A3 en el macho apreciablemente más corto que A4; vena marginal del ala anterior 2-3 veces más larga que la vena estigmal (fig. 81); Neártica y Neotropical ..................

Paramesius Westwood o ô (parte) (p. 52)

- $\quad$ Esternito apical de la hembra poco desarrollado, más corto que 3 esternitos precedentes (figs. 53, 56); A3 en el macho similar o más largo que A4; vena marginal del ala anterior generalmente corta (figs. 60, 85), menos freqentemente más larga que la estigmal (figs. 53, 56) . . . . . . . 17

17(16). Ala posterior con la celda basal cerrada (figs. 53, 56); fosa escutelar anterior bifoveada, las foveas frecuentemente se confunden con la fuerte esculturación que las rodea; epomium siempre muy bien desarrollado (figs. 53, 56)

$\ldots \ldots \ldots \ldots \ldots \ldots \ldots$

Ala posterior sin celda basal cerrada (figs. 60, 85); fosa escutelar anterior trifoveada (fig. 59) o la fosa reemplazada por un arco de pequeñas puntuaciones o crenulas (fig. 86); epomium sólo raras veces desarrrollado ... 19

18(17). Borde apical de A1 continuo, sin una excavación ventral, ni producido en láminas (fig. 55b); clipeo claramente más ancho que largo, margen anterior recto y no prominente; mejilla sin estriaciones (fig. 56); Valdiviana ... .... Ferrugenus, genero nuevo

(p. 48)

- Borde apical del A1 profundamente excavado ventralmente y con expansiones laminares (p.ej., fig. 55a); clipeo ligeramente alargado, con el margen anterior prominente; mejilla frecuentemente con estrias cortas en forma de abanico (fig. 53); Valdiviana

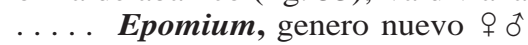
(p. 46)

19(17). Quilla media del propodeo fuertemente desarrollada, puntiaguda, generalmente dirijida hacia atrás (fig. 60); vena postmarginal del ala anterior moderada a claramente desarrollada (fig. 60); vena basal del ala anterior recta, inclinada formando un ángulo agudo junto a la vena submarginal (fig. 60); cuerpo generalmente con coloración clara; Neártica y Neotropical

Idiotypa Foerster ơ (parte) (p. 51)

Quilla media del propodeo sólo moderadamente desarrollada, rudimentaria, 
o ausente (fig. 85), muy raramente puntiaguda; vena postmarginal del ala anterior rudimentaria; vena basal del ala anterior moderada a fuertemente arqueada (fig. 85); coloración del cuerpo usualmente negra; Neártica y Neotropical .... Pentapria Kieffer $q$ o (parte) (p. 54)

20(1). Antena con 13 segmentos. ...... 21

- Antena con un número diferente de segmentos ... . . . . . . . . . 29

21(20). Alas reducidas, usualmente no sobrepasan el pecíolo, venas reducidas o ausentes, o alas completamente ausentes $\ldots \ldots \ldots \ldots 22$

- Alas bien desarrolladas, alcanzando o sobrepasando el ápice del metasoma, venas submarginal y marginal presentes ............... 24

22(21). Margen anterior del sintergito recto, sin incision, emarginación, o excavación; Neártica y Neotropical ... Spilomicrus Westwood $q$ ơ (parte) (p. 57)

- Margen anterior del sintergito con incisión, emarginación o excavación ... ................ 23

23(22). Surco malar desarrollado; clava antenal en la hembra abrupta de 3 segmentos; cuerpo de coloración clara, desde anaranjado hasta amarillo; Valdiviana .... ¿Idiotypa? Foerster $\uparrow$ (parte) (p. 52)

- Surco malar ausente; clava antenal en la hembra gradual; cuerpo de coloración obscura generalmente negra; Neotrop-

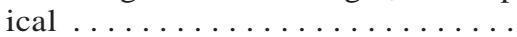
.... Pentapria Kieffer o o ò (parte) (p. 54)

24(21). Vena submarginal del ala anterior muy próxima al margen anterior del ala, i.e., celda costal casi ausente (fig. 69); fosa escutelar anterior ausente; A13 en la hembra muy desarrollado, ovoide (fig. 69); pecíolo y propodeo completamente cubiertos por una densa pilosidad pálida semejante a una alfombra; Neártica y Neotropical ....

Monelata Foerster $q$ (parte) (p. 93)

Vena submarginal del ala anterior claramente separada del margen anterior del ala, i.e., celda costal al menos tan ancha como la vena submarginal (figs. $50,81) \ldots \ldots \ldots \ldots \ldots \ldots$

25(24). A13 en la hembra moderado o apreciablemente mayor que A12 (fig. 81); A3 en el macho claramente más corto que A4; vena marginal del ala anterior man- ifiestamente más larga que la vena estigmal; Neártica y Neotropical .... . . Paramesius Westwood $q$ ô (parte)

(p. 52)

- A13 en la hembra similar en tamaño a A12 o menor; A3 en el macho similar en longitud a A4 o más largo; vena marginal del ala anterior similar en longitud a la vena estigmal, en raras ocasiones ligeramente más larga . . . . ............... 26

26(25). Fosa escutelar anterior ausente (fig. 24); pronoto dorsalmente con una elevación aguda (fig. 23); propodeo y pecíolo densamente cubiertos a manera de una alfombra por pubescencia diminuta y aterciopelada; Sur América

... Bruchopria Kieffer + ô (p. 39)

Fosa escutelar anterior presente, entera o bifoveada ............ 27

27(26). Vena estigmal del ala anterior claramente alargada (fig. 50); margen anterior del sintergito con una incisón o excavación, frecuentemente también flexionado (fig. 49); ápice del ala anterior frecuentemente subtruncado o emarginado; Neártica y Neotropical ..... Entomacis Foerster $q$ ô (parte) (p. 44)

- Vena estigmal del ala anterior corta (p.ej., fig. 97); margen anterior del sintergito recto; ápice del ala anterior redondeado ............ 28

28(27). Fosa escutelar anterior bifoveada; vena basal del ala anterior generalmente presente (nebulosa); frente lisa, sin proyecciones; Neártica y Neotropical ... .. Spilomicrus Westwood $q$ ô (parte) (p. 57)

- $\quad$ Fosa escutelar anterior entera; vena basal del ala anterior ausente; frente con dos proyecciones agudas y un pliege transverso (fig. 67); Sur América ... .... Mitropria Ogloblin đิ (parte)

(p. 92)

29(20). Alas reducidas, usualmente sin sobrepasar el pecíolo, venas reducidas o ausentes, o alas completamente ausentes ............. 30

- Alas completamente desarrolladas, usualmente sobrepasando el ápice del metasoma, venas submarginal y marginal presentes .......... 50

30(29). Cabeza claramente opistognata (fig. 29); frente con proyecciones agudas sobre los ojos; ojos reducidos a un simple omatidio, o raras veces totalmente ausentes; cabeza y mesosoma usual- 
mente con escultura granular o con puntuaciones bien desarrolladas $\mathrm{y}$ densas; Neotropical ............ .... Caecopria Masner of ${ }^{\text {o }}$ (parte) (p. 113)

- Cabeza normal, hipognata ..... 31

31(30). Margen anterior del sintergito modificado, con incisión medial, o algunas veces flexionado (p.ej., fig. 59); Neotropical y Valdiviana ..... Idiotypa Foerster + (parte) (p. 51), ¿Idiotypa? (especies Valdivianas) (p. 52)

- Margen anterior del sintergito sin modificaciones, sin incision, sin estar flexionado (p.ej., figs. $8,12,51,70$ ) . . $\ldots \ldots \ldots \ldots \ldots \ldots \ldots 2$

32(31). Todos los tarsos moderada a fuertemente comprimidos, más altos que anchos (figs. 58, 66, 72, 76); patas extremadamente largas y desarrolladas, tibias posteriores típicamente comprimidas sólo en el extremo basal (figs. 52, 58, 66, 72, 76); cuerpo más bien grande $(2-6 \mathrm{~mm})$, frecuentemente con escultura, setas especializadas y/o coloración clara, de ferruginea a amarilla; especies asociadas con hormigas ........... 33

- Todos los tarsos cilíndricos, casi tan altos como anchos; patas normales cortas y gruesas, tibias posteriores típicamente comprimidas en la mitad anterior; cuerpo más bien pequeño (ca.1 $\mathrm{mm}$ ), siempre liso, de coloración obscura, raramente de coloración clara o con setas especializadas; especies terrícolas, raramente asociadas con hormigas .............. 44

33(32). Antena con 11 segmentos . . . . . 34

- $\quad$ Antena con 12 segmentos ....... 37

34(33). Pronoto anteromedialmente (no en los hombros) proyectado hacia adelante en un proceso trunco (fig. 74); metaesterno (entre las coxas medias y posteriores) producido en una furca (fig. 76, flecha); Sur América .... .... Notoxoides Ashmead $q$ (parte) (p. 97)

- $\quad$ Pronoto anteriomedialmente sin proyección (hombros algunas veces más anchos de lo normal); metaesterno sin furca ............. 35

35(34). Vértice marcadamente elevado (fig. 100 ); pronoto con un área rugosa bien diferenciada en la zona del epomium; antena en la hembra con 11 segmentos; mesopleuron frecuentemente con estrias horizontales finas; Centro y
Sur América ...............

Turripria, genero nuevo $q$ (parte)

(p. 110)

Vértice normalmente arqueado (figs. 13, 72) .............. 36

36(35). Depresión frontal claramente marginada en la parte posterior (con un punto medio) y lateralmente (torus sobre los ojos) (figs. 70, 72); ápices internos de las tibias anteriores y medias proyectados agudamente (fig. 71); ojos pequeños, subcirculares (fig. 72); Neártica (sur este de Estados Unidos) ...

Myrmecopria Ashmead $q$ (parte)

(p. 94)

- Depresión frontal sin marginar, sin punto medio o tori sobre los ojos, ápices de las tibias anteriores y medias no proyectados; ojos grandes, similares a una gota invertida (fig. 13); Centro y Sur América ..... Asolenopsia Kieffer $q$ (parte) (p. 65)

37(33). Quilla media del propodeo moderada a fuertemente elevada; propodeo mas bien corto y de pendiente escarpada o abrupta (figs. 10, 11, 13, 84) . . 38 Quilla media del propodeo levemente levantada sólo anteriormente, típicamente muy baja o completamente ausente; propodeo moderado marcadamente alargado, sólo de pendiente suave o subhorizontal (figs. 9, 52, 73) ................. 39

38(37). Depresión frontal claramente delimitada posteriormente (con un punto medio) y lateralmente (torus sobre el ojo)

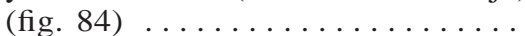

..Philolestoides Ferrière $q$ (p. 101)

Depresión frontal sin delimitar, sin punto o tori (fig. 13); Centro y Sur América .................. .... Asolenopsia Kieffer (parte) (p. 65)

39(37). Ojos ausentes (fig. 9); espinas de las tibias ausentes; palpos ausentes; basitarsos anteriores y medios ventralmente proyectándose en fuertes espinas (fig. 9); dorsellum marcadamente desarrollado; Neártica (Florida) .......... . .. Apopria, genero nuevo $q$ (p. 63) Ojos, espinas de las tibias y palpos presentes; basitarsos anteriores y medios sin proyectarse ventralmente; dorsellum relativamente corto .....440

40(39). S2 medialmente con un penacho de densa pubescencia (fig. 73); temple y postgena con una fuerte quilla irreg- 
ular (fig. 73); epomium proyectándose anteriormente en una fina lámina; Sur

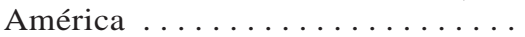

... Neivapria Borgmeier $q$ (p. 96)

$\mathrm{S} 2$ sin penacho de pelos; temple y postgena $\sin$ quilla; epomium ausente ... ............... 41

41(40). Parte anteromedial del mesoescuto fuertemente encorvada (figs. 51, 52); parte posterior del propodeo alargada, comprimida, dando la impresión de un pecíolo con dos segmentos (figs. 51, 52); Neártica y Centro América ... .... Ecitovagus Masner $q$ ồ (parte) (p. 77)

- Mesoescuto normal (figs. 58, 64, 66); propodeo de forma diferente . . . 42

42(41). Metasoma después del peciolo corto, subglobular, sintergito en vista lateral marcadamente convexo (fig. 58); especies de tamaño pequeño de $1.5-2.5$ mm de longitud; Neártica, Centro y Sur América .............. ... Labidopria Wasmann $q$ (parte) (p. 83)

- Metasoma después del pecíolo moderadamente alargado, ovoide, sintergito en vista lateral sólo moderadamente convexo (figs. 64, 66); especies mayores, de $3.5-5.5 \mathrm{~mm}$ de longitud . . ............... 43

43(42). Frente con proyecciones mediales de moderadas a fuertes (puntos) y lateralmente (torus sobre el ojo) (figs. 65, 66); metaesterno detrás de la coxa media recto, no excavado (fig. 66); cabeza y mesosoma predominantemente o completamente esculturados; Sur América .. Mimopria Holmgren ơ ồ (parte) (p. 89)

Frente sin proyecciones (fig. 64); metaesterno detrás de la coxa posterior excavado (fig. 64); cabeza y mesosoma predominantemente lisos; Centro y Sur América ..............

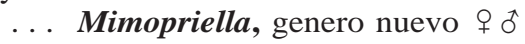
(parte) (p. 90)

44(32). Pecíolo producido dorsalmente por encima del margen anterior del sintergito (fig. 25); antena de la hembra usualmente con 11 segmentos y una clava abrupta de 3 segmentos; propodeo anteriormente con una fuerte constricción, moderado a claramente excavado posteriormente (fig. 26); Neártica .... Bruesopria Wing $q \hat{\sigma}$ (parte) (p. 72)
- Pecíolo subcilindrico, tan largo como ancho o ligeramente alargado, sin proyectarse sobre el sintergito ...

................ 45

45(44). Propodeo con una profunda excavación posteromedialmente, en forma de herradura (figs. 6, 16) . . . . . . 46 46

- $\quad$ Propodeo posteromedialmente sin excavación .............44 47

46(45). Cabeza claramente alargada; mandíbulas falcadas, opistognatas (figs. 6, 7); tergitos después del tergito mayor (sólo T2) extremadamente cortos, comprimidos (fig. 6); Neártica (Cali-

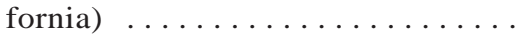
... Aneuropria Kieffer ot ơ (p. 31)

Cabeza subglobosa (fig. 17); mandíbulas cerradas sobre sí mismas, hipognatas; tergitos después del sintergito (T2 + T3) anchos, no comprimidos (fig. 19); Neártica, México, ¿Antillas? .....

.. Auxopaedeutes Brues $q$ ô (parte)

(p. 67)

47(45). Antena en la hembra de 11 segmentos, A10 y A11 marcadamente desarrollados (fig. 44); área del propodeo entre la quilla media y la plica casi glabra; Neártica y Neotropical ...... ..... Doliopria Kieffer $q$ o (p. 76)

- $\quad$ Antena de la hembra con 12 segmentos

48(47). C............... . 48

48(47). Cabeza dorsal y lateralmente alargada, ojos pequeños y salientes (fig. 90); A1 en los machos muy desarrollado $\mathrm{y}$ abultado, segmento sexual en A3 (fig. 91); basitarsos anteriores de los machos distalmente expandidos; Neártica (Holártico) ............... .... . Platymischus Westwood (p. 102)

- Cabeza dorsal y lateralmente más o menos globular; ojos algunas veces pequeños pero nunca salientes; A1 en el macho normal, cilíndrico, segmento sexual en A4; basitarsos anteriores de el macho normales, no expandidos . . ............... 49

49(48). Antena de la hembra con una clava abrupta de 3 ó 4 segmentos (fig. 22); área del propodeo entre la quilla media y plica casi glabra; Neártica y Neotropical .............. ... Basalys Westwood o ô (parte)

(p. 70)

- $\quad$ Antena de la hembra con la clava gradual, no abrupta (fig. 99); área del propodeo entre la quilla media y plica pubescente; Neártica y Neotropical 
... Trichopria Ashmead + ô (parte)

50(29). Vena submarginal del ala anterior distintivamente separada del margen anterior al menos por una distancia igual al diámetro de la vena (figs. 22, 44; más fácil de apreciar en la mitad anterior de la vena); vena marginal alcanzando o sobrepasando el tercio basal de la longitud del ala ..... 51

- Vena submarginal del ala anterior muy próxima al margen anterior del ala, casi contigua (figs. 64, 69); vena marginal no llega a alcanzar el tercio basal de la longitud del ala. ...... 53

51(50). Ala anterior con vena basal (fig. 22); antena de la hembra con 12 segmentos; Neártica y Neotropical .... Basalys Westwood 9 ô (parte) (p. 70)

- $\quad$ Ala anterior sin vena basal; antena de la hembra con 11 segmentos ..... 52

52(51). Frente con dos proyecciones puntiagudas y una carena transversal (fig. 67); clava antenal de la hembra abrupta y de 3 segmentos; Sur América .... .... Mitropria Ogloblin + (parte) (p. 92)

- $\quad$ Frente sin proyecciones o carenas, muy raramente con una pequeña proyección puntiforme en la parte anteromedial; A10 y A11 de la antena de la hembra muy desarrollados, clava fuerte pero gradual (fig. 44); Neártica y Neotropical ............... .... Doliopria Kieffer o 9 o (parte)

(p. 76)

53(50). Inserción de A2 claramente antes del ápice de A1 (fig. 95); antena de la hembra de 11 segmentos; vértice elevándose notablemente sobre el nivel de los ojos (fig. 95); Sur América . . .... Szelenyisca Masner $q$ (p. 106)

- $\quad$ Inserción de A2 en el ápice de A1 . . . .................. 54

54(53). Vértice marcadamente elevado (fig. 100); pronoto con una área rugosa en la región del epomium; antena de la hembra con 11 segmentos; mesopleuron frecuentemente con estrias horizontales finas; Centro y Sur América ...

. . Turripria, genero nuevo + (parte)

(p. 110)

- Vértice normalmente arqueado (figs. 58, $61,64,98) \ldots \ldots \ldots \ldots \ldots \ldots 55$

55(54). Todos los tarsos moderada a fuertemente comprimidos, más altos que anchos (figs. 58, 66, 72, 76); cabeza y mesosoma generalmente con escul- tura y con setas especializadas; especies asociadas con hormigas .... 56

Todos los tarsos más o menos cilíndricos, tan altos como anchos; cabeza y mesosoma sólo raras veces esculpidas, usualmente lisos y brillantes, sólo muy raras veces con setas especializadas; principalmente especies de vida libre, raramente asociadas con hormigas ............66 66

56(55). Depresión frontal claramente delimitada, con un punto medio y/o torus lateral sobre el ojo (figs. 52, 65, 72, 74, 84) .............. 57

- Depresión frontal sin delimitar, sin punto medio ni torus sobre el ojo (figs. $13,58,61,64,73,98) \ldots \ldots 661$

57(56). Pronoto anteromedialmente (no en los hombros) proyectado hacia adelante en un proceso trunco (fig. 76); metaesterno (entre las coxas medias y posteriores) producido en una furca (fig. 76, flecha); Sur América .... . . Notoxoides Ashmead + ot (parte) (p. 97)

- $\quad$ Pronoto no producido (hombros algunas veces más anchos de lo normal); metaesterno sin furca ......... 58

58(57). Parte anteromedial de mesoescuto fuertemente encorvada (fig. 51); parte posterior del propodeo alargada y comprimida, dando la impresión de un pecíolo con 2 segmentos (figs. 51, 52); Neártica y Centro América .... .... Ecitovagus Masner + o (parte)

(p. 77)

- Mesoescuto anteromedialmente normalmente arqueado (figs. 66, 72, 84); propodeo de forma distinta .... . 59

59(58). Ápices internos de las tibias anteriores y medias proyectados en fuertes espinas (fig. 71); tibias medias y posteriores solamente con espinas rudimentarias; antena de la hembra con 11 segmentos; Neártica (sur este de Estados Unidos) ..............

Myrmecopria Ashmead of to (parte) (p. 94)

- $\quad$ Ápices internos de las tibias anteriores y medias sin proyectarse; tibias medias y teriores con dos espinas normales; antena de la hembra con 12 segmentos ............6 60

60(59). Propodeo muy corto, de pendiente escarpada o abrupta, con una quilla media moderada o fuerte (fig. 84); cuerpo con pubescencia fina, acuminada; Sur América .............. 
... Philolestoides Ferrière + (parte) (p. 101)

- $\quad$ Propodeo claramente alargado, subhorizontal (fig. 66), quilla media ausente o rudimentaria; cuerpo con cerdas fuertes, cerdas frecuentemente truncadas en el ápice; Sur América ....

Mimopria Holmgren + o (parte)

(p. 89)

61(56). S2 con un penacho de densa pubescencia (fig. 73); epomiun proyectándose anteriormente en una fina lámina; zona temporal y postgena con una quilla fuerte irregular; Sur América .... Neivapria Borgmeier of (parte) (p. 96)

- $\quad$ S2 sin penacho de pelos; epomiun usualmente no desarrollado; zona temporal y postgena lisa o coricea, muy raramente con una quilla diminuta ..............6 62

62(61). Quilla media del propodeo moderada a fuertemente desarrollada (figs. 11, 61, 98) ................6 63

Quilla media del propodeo cuando mucho rudimentaria y sólo en la parte anterior (figs. 58, 64) ......6 65

63(62). Quilla media del propodeo proyectándose anteromedialmente en un largo proceso digitiforme, con frecuencia curva hacia atrás (fig. 61); ápice del metasoma en la hembra con un área extensa de coloración blancuzca o amarillenta; A3-A13 en el macho siempre con dos nudos o engrosamientos moderados, los cuales pueden poseer verticilos de cerdas o bien pelos esparcidos al azar en todo el segmento; Centro y Sur América .... .... Leucopria, genero nuevo $q$ t (p. 85)

Quilla media del propodeo sin proyectarse en un largo proceso digitiforme (figs. 11, 98); ápice del metasoma en la hembra sin áreas de coloración más clara que el resto; macho (Asolenopsia gibba) A4-A14 con solo un verticilo de cerdas ...........6 64

64(63). Ojo en vista lateral moderada a distintamente más alto que largo, casi similar a una gota invertida (fig. 13); cabeza en vista lateral ligeramente más alta que larga; mechones de densa pubescencia o áreas con estructuras eponjosas presentes en varias partes del cuerpo; Centro y Sur América . . ... Asolenopsia Kieffer of ô (parte)

(p. 65)
Ojo en vista lateral subcircular (fig. 98); cabeza en vista lateral subglobular; sin mechones de pubescencia o estructuras esponjosas; Neártica (Sonora) ..................

Townesella Huggert and Masner $q$ (p. 107)

65(62). Propodeo en vista lateral moderado o claramente alargado, frecuentemente con el dorso subhorizontal (fig. 64); fémur posterior sólo ligeramente comprimido anteriormente (vista dorsal); metasterno anteriormente (detrás de la mesocoxa) con una excavación profunda semicircular (fig. 64); Centro y Sur América . . . Mimopriella, genero nuevo o 8 (parte) (p. 90)

- Propodeo en vista lateral corto, claramente inclinado hacia abajo (fig. 58); femur posterior marcadamente comprimido anteriormente (vista dorsal); metaesterno anteriormente sólo con una pequeña y poco profunda invaginación; Neártica, Centro y Sur América ................. ... Labidopria Wasmann $q$ (parte) (p. 83)

66(55). Cara o la cabeza por completo, frecuentemente también el mesoescuto o el gran sintergito cubiertos con pubescencia fina semiadosada (figs. 93, 94); placa antenal entre los toruli sin desarrollar; distancia entre los toruli mayor o similar a la distancia entre el torulus y la orbita interna del ojo (fig. 93); margen anal del ala anterior claramente angular (fig. 94); antena de la hembra con 11 segmentos; hábitos acuáticos; Neártica y Neotropical .... . . Psychopria, genero nuevo + to

(p. 103)

- Cara y otras partes del cuerpo glabras o sólo con algunos pocos pelos o cerdas esparcidos; placa antenal entre los toruli aguda, carenada; distancia entre los toruli similar o más corta que la distancia entre cada torulus y la órbita interna del ojo; margen anal del ala anterior no angulado; antena de la hembra predominantemente con 12 segmentos; sólo unas pocas especies acuáticas ..............6 67

67(66). Pecíolo grande, robusto, en forma de ánfora, dorsalmente liso y glabro (fig. $36)$; esternito apical en la hembra con una cubierta masiva de cerdas muy gruesas y fuertes, amarillentas (fig. 
35); patas marcadamente cortas y fuertes, basitarsos medios y posteriores acortados (fig. 36); Centro y Sur

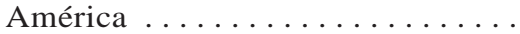

. Cruzium, genero nuevo ${ }^{\circ}$ (p. 73)

Pecíolo de forma diferente, usualmente mas pequeño, esculpido y/o piloso; esternito apical en la hembra sin la cubierta masiva de cerdas .....668

68(67). Disco escutelar claramente cóncavo al meson, con quillas laterales elevadas; antena de la hembra sin clava, A4A11 moniliformes (fig. 20); depresión axilar, metanoto y parte dorsal del propodeo cubiertos con pilosidad densa y larga; Neártica (Florida), Antillas (Jamaica), Centro América ...

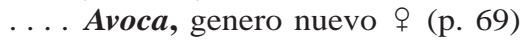

Disco escutelar aplanado o ligeramente convexo y/o con quillas en el meson, quillas laterales no elevadas .... 69

69(68). Pecíolo en vista lateral mucho más alto que ancho, con una proyección digitiforme dorsal sobre el margen anterior del sintergito (fig. 25); propodeo anteriormente con una fuerte constricción (fig. 26); antena de la hembra con clava abrupta de 3 segmentos; Neártica .................. ..... Bruesopria Wing of ô (parte) (p. 72)

Pecíolo en vista lateral al mismo nivel o más bajo que el margen anterior del sintergito; propodeo sin constricción anterior ........... 70

70(69). Parte posteromedial del propodeo con una profunda excavación alcanzando casi el margen posterior del dorsellum, p.ej. parte media y quilla ausentes, lados en forma de herradura (fig. 16); individuos de tamaño pequeño, alrededor de 1, $0 \mathrm{~mm}$, marrón claro a obscuro, patas cortas y robustas; Neártica, México, ¿Antillas? ..... .. Auxopaedeutes Brues of to (parte) (p. 67)

Parte posteromedial del propodeo a lo sumo moderadamente cóncavo, parte media y quilla usualmente bien desarrolladas, lados diferentes a una herradura ............. 71

71(70). Occipucio posteromedialmente con una espina recta, vertical (fig. 62): A1 con quillas longitudinales finas, borde apical foliáceo o espiniforme (quilla media del propodeo muy desarrollada, dirigida hacia atrás [fig. 62]; A3-A14 en el macho con escultura fina e ir- regular y pelos largos esparcidos sin formar verticilos); Centro y Sur América .................

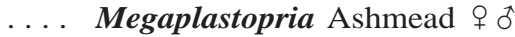
(p. 87)

- $\quad$ Occipucio sin espina; A1 sin quillas longitudinales y con el borde apical redondeado ............. 72

72(71). Pecíolo y propodeo completamente cubiertos por una densa pilosidad, semejante a un alfombra que impide ver su superficie (figs. 68, 69); especies diminutas, gráciles, aproximadamente de $1 \mathrm{~mm}$ de longitud; fosa escutelar anterior ausente (fig. 68); A4 en el macho no está modificado; Neártica y Neotropical ............... ..... Monelata Foerster $q$ (parte)

(p. 93)

- Pecíolo y propodeo cuando mucho con pelos esparcidos, superficie bien visible .............. 73

73(72). Hombros del pronoto fuertemente desarrollados, con los bordes agudamente flexionados (fig. 77); cuerpo con setas esparcidas, rectas, fuertes y apicalmente truncadas; antena de la hembra con 12 segmentos; A3-A13 en el macho con pelos esparcidos sin formar verticilos; Sur América .....

Omopria, genero nuevo of ô (p. 99)

- Hombros del pronoto cuando mucho moderadamente desarrollados, sin estar flexionados, claramente redondeados ............... 74

74(73). Cuerpo con setas esparcidas, rectas y truncada; cuerpo robusto; antena de la hembra con 11 segmentos, muy raras 12 segmentos; A3-A13 en el macho verticilados; lados del propodeo fuertemente proyectados posterolateralmente (fig. 96); Centro y Sur América ....... Szelenyiopria Fabritius $\uparrow \circlearrowleft$

(p. 105)

- Cuerpo con setas adosadas al cuerpo y acuminadas ........... 75

75(74). Ápice de la tibia anterior proyectándo dorsalmente en una espina ligeramente curvada ..........76

Ápice de la tibia anterior sin proyección dorsal . . . . . . . . . . . . . 77

76(75). Margen anterior del sintergito moderada a claramente flexionado, e inciso medialmente; clava antenal de la hembra subpentamera (fig. 38); A3 en el macho con una quilla longitudinal; Neártica (D. conica [Fabricius] cosmopol- 
ita) $\ldots \ldots \ldots \ldots \ldots \ldots \ldots$

.... . Diapria Latreille $q$ ơ (p. 75)

Margen anterior del sintergito recto, sin flexionar ni inciso; clava antenal de la hembra usualmente con menos de 5 segmentos (fig. 99); A3 en el macho sin quilla; Neártica y Neotropical .. .

... Trichopria Ashmead o ô (parte)

(p. 108)

77(75). Antena de la hembra con 11 segmentos, A3-A13 en el macho con pelos esparcidos no verticilados, A3 y A4 claramente separados ...... 78

Antena de la hembra con 12 segmentos; A3-A13 en el macho con un verticilo de cerdas largas, A3 y A4 fusionados (figs. 1, 2) ........... 79

78(77). Ala anterior con cilias marginales presentes; A11 en la hembra notablemente desarrollado, formando una clava de 1 segmento (fig. 57); mandíbulas y clípeo no están separados por una hendidura o surco profundo; Centro y Sur América .......... ..... Hansona, genero nuevo $q \widehat{o}$

(p. 81)

Ala anterior sin cilias marginales; A11 en la hembra similar en tamaño a los clavómeros precedentes (fig. 102); con una profunda hendidura entre las mandíbulas y el clípeo (fig. 102); Sur América .................

.... Xanthopria Brues o (p. 112)

79(77). Margen interno de las tibia posterior con un cepillo denso de setas (fig. 46); quilla media del propodeo moderada a claramente espatulada, dorsalmente aplanada (fig. 45, 47); cuerpo completamente esculpido, reticulando o delicadamente mate (fig. 45); Centro y Sur América ..............

.. Eladio, genero nuevo ơ ơ (p. 79)

Margen interno de la tibia posterior cuando mucho con una hilera fina de setas; quilla media del propodeo no espatulada, usualmente puntiaguda y curvada hacia atrás (fig. 5) o casi ausente; cuerpo usualmente liso y brillante, raramente ruguloso, nuncua reticulando o mate; Neártica (Arizona, Texas) y Neotropical ...........

Acanthopria Ashmead $q$ ơ (p. 61)

\section{SYSTEMATICS}

TRIBE PSILINI HELLÉN 1963

DiAgnosis: Predominantly medium to large-sized individuals, body deep black with no foamy structures; labrum exposed, sclerotized and deeply pigmented, triangular in shape; hypostomal bridge absent; tentorial pits present; malar sulcus absent; mandibles bidentate, usually beaklike, projecting backward, rarely mandibles clasped; antennal formula $12-14$, rarely $11-13$, female clava usually nonabrupt, multisegmented, rarely 1segmented, male antenna with nonverticillate hairs; spiracle on pronotum spikelike, protruding; notaulus in winged forms always developed, percurrent; anterior scutellar pit bifoveate, lateral pits present, posterior scutellar pits present or absent; epicnemial pit and sternaulus often present; costal vein absent, costal cell wide open, submarginal vein in forewing at most glassy (depigmented), rudimentary, or absent, not reaching foremargin of wing; large tergite of metasoma composed of single tergum T2, i.e., macrotergite; following tergites usually very narrow, closely appressed, sometimes forming carapace, apical sternite in female rounded, not pointed.

REMARKs: The Psilini is unique among the tribes of the Diapriinae in having a macrotergite (T2) instead of a syntergite (T2 + T3). This character state together with the exposed, sclerotized labrum would make Psilini a rather plesiomorphic group. However, the highly derived venation of the forewing and the unique shape of the spiracle on the pronotum are interpreted as strong synapomorphies. We classify here four genera: Aneuropria Kieffer, Coptera Say, Ortona, new genus, and Psilus Panzer. The known hosts comprise several families of Diptera; no myrmecophilic or aquatic members occur in the Psilini.

\section{Aneuropria Kieffer \\ Figures 6, 7}

Aneuropria Kieffer, 1905. Ann. Mus. Civ. Stor. Nat. Genova 2(2): 9.

Pezopria Kieffer, 1911. in André, Spec. Hym. Eur. Alg. 11: 88. Synonymized by Masner and Sundholm, 1959. Čas. Česk. Spol. Entomol. 56: 151.

Diagnosis (New World only) ( $\left.\begin{array}{l}0 \\ 0\end{array}\right)$ : Small-sized (1-2 mm) individuals; body color deep black with appendages lighter, predominantly smooth, highly shining, with rel- 
atively little pilosity (dense silvery pilosity on petiole and propodeum) some hairy cushions, but no foamy structures; labrum subtriangular, exposed, sclerotized; oral carina strongly developed permitting movement of mandible only along vertical axis; mandible long, falcate, bidentate, distinctly projecting backward (opisthognathous); A1 unarmed, without apical flaps; A4 in male not modified; median keel of propodeum strongly reduced; plica strongly developed, projecting posteriorly, almost bladelike, posterior margin of propodeum deeply excavate; petiole short, about as long as wide, anterior margin on T2 (macrotergite) not notched medially.

DESCRIPTION (New World only) ( + to ): HEAD. Head in dorsal view moderately elongate, antennal shelf and toruli strongly protruding, shelf entire but distinctly notched medially; vertex gradually sloping into occiput, without step; temple distinctly longer than length of eye; head in lateral view subtriangular; antennal shelf strongly projecting forward; level of toruli in lower half of eye; eye remarkably small, subcircular, considerably shorter than postgena, ocelli small or absent; oral carina strongly developed, semicircular, bladelike; postgenal cushion strongly developed (better viewed ventrally); occipital flange strongly reduced, narrow; head in frontal view with face long, moderately convex, without lateral depressions; clypeus moderately convex; epistomal sulcus weakly indicated; labrum exposed, sclerotized, sharply subtriangular; malar sulcus not developed; malar space considerably longer than eye height; tentorial pit large; mandible long, falcate, bidentate, distinctly projecting backward (opisthognathous) moving only in vertical axis; palpi very short, appearing 42 ; head in ventral view with hypostomal bridge not developed; antennal formula 1214; A1 relatively long, cylindrical, unarmed medially, without flaps apically, not emarginate ventrally; female antenna with nonabrupt, multisegmented clava; clavomeres moderately flattened ventrally, A12 longest and largest, with ventral pit; male antenna filiform, slightly subclavate apically, with short scattered nonverticillate hairs, A3 subequal to A4, A4 not modified. MESOSOMA. Mesosoma moderately elongate, usually as wide as high, remarkably flattened dorsally; pro- thorax in dorsal view well developed; pronotal shoulders not developed but with dense hairy cushion; side of pronotum almost flat, with dense hairs along anterior margin; epomium not developed; spiracle only moderately protruding; propleuron entirely hairy; mesoscutum fused with scutellum in single plate, transscutal articulation absent, mesoscutum smooth, shining and glabrous with only few setigerous punctures, without furrows or sulci; tegula present, small; axillar depression minute; mesopleuron almost flat, highly smooth, shining, glabrous, median oblique depression not developed; epicnemial pit rudimentary, epicnemial carina not developed; sternaulus strong, percurrent, noncrenulate; posterior margin of mesopleuron noncrenulate; metanotum and dorsellum rudimentary or absent; metapleuron with row of large crenulae along posterior margin of mesopleuron, otherwise almost smooth but with dense appressed micropilosity; propodeum relatively large; median keel of propodeum strongly reduced; plica glabrous, strongly developed, projecting posteriorly, almost bladelike, posterior margin of propodeum deeply excavate; nucha short; wings reduced to stumps, not exceeding posterior margin of propodeum; legs moderately elongate, femora distinctly clavate, with minute flaps apically. METASOMA. Metasoma short pedunculate; petiole short, about as long as wide; anterior margin on T2 (macrotergite) not notched medially; S2 with dense pilosity basally.

RECOGNITION AND Relationships: Aneuropria is predominantly an Old World genus; so far, we examined one species in the New World (USA, California). The latter is an undescribed species, certainly marginal to the generic concept of Aneuropria. The falcate mandibles and the correlated shape of the head is indeed atypical for Aneuropria but known to us in one undescribed Ethiopian species from Kenya (CNCI). Aneuropria differs from Ortona principally by the nonnotched anterior margin of T2, from Psilus and Coptera also by the unarmed A1. The strong development of plicae is the main apomorphy for all members of Aneuropria.

Distribution: We know only one undescribed species in the New World (see above).

BIOLOGY: One Palearctic species is record- 
ed from pupae of cherry fruit fly (Rhagoletis, Tephritidae).

\section{Coptera Say}

Figure 37

Coptera Say, 1836: 281.

Schizogalesus Kieffer, 1911: 832, 833.

Diagnosis ( $q$ $₫)$ : Medium to large- sized (3-7 $\mathrm{mm})$ individuals, rarely body size smaller (1.5-2 mm); body color deep black with appendages usually lighter; body predominantly smooth, highly shining, very rarely with dense, fine longitudinal microsculpture on mesonotum, body relatively glabrous, usually with hairy cushions but no foamy structures; occiput usually sharp posteriorly, steplike; labrum exposed, sclerotized, subtriangular; oral carina strongly developed permitting movement of mandible only along vertical axis; mandible long, falcate, bidentate, distinctly projecting diagonally backward; antenna apparently capable of rotation in socket permitting variable positions; A1 in both sexes relatively short, highly modified, often with multiple sharp projections, always with distinct flaps apically; male A3 subequal in length to A4; female forewing always with longitudinal fold and apical excision, male forewing with or without fold or excision; forewing almost veinless, submarginal vein incomplete, reduced to short basal stem; T2 (macrotergite) with deep median cleft.

DESCRIPTION ( $q$ ô): HEAD. Head in dorsal view variously shaped, subglobular, often strongly elongate, rarely transverse, with shelf and toruli moderately to strongly protruding; frons always armed with multiple projections, points, ledges or carinae, often with scattered deep setigerous punctures; occiput usually steplike, sharply carinate, almost right angled above occipital flange; temple of variable length, subequal to shorter or longer than length of eye; head in lateral view subtriangular; antennal shelf moderately to distinctly developed; level of toruli at midpoint of eye; eye relatively large, subellipsoidal; oral carina strongly developed, semicircular, bladelike, permitting movement of mandible only along vertical axis; postgenal cushion usually well developed, rarely reduced or absent; occipital flange moderate- ly developed, rarely almost absent, usually noncrenulate; head in frontal view with face strongly convex medially, depressed laterally; clypeus highly convex, as high as wide or higher; epistomal sulcus not developed; labrum exposed, sclerotized, perfectly triangular; malar sulcus not developed; gena between lower eye orbit and mandibular condyle usually distinctly shorter than eye height; tentorial pit large; mandible long, falcate, not clasped, parallel, bidentate, distinctly projecting diagonally backward; palpal formula 5-2; head in ventral view with hypostomal bridge not developed; antennal formula 12-14; A1 relatively short, highly modified, often with multiple sharp projections, always with distinct flaps apically; female antenna with nonabrupt, multisegmented clava, clavomeres often flattened ventrally, A12 often longest, without ventral pit; male antenna filiform, rarely beadlike, A3-A14 with dense, moderately long, nonverticillate hairs, A3 subequal in length to A4, A4 at most moderately modified, usually without carina. MESOSOMA. Mesosoma moderately to distinctly long, usually as wide as high, moderately convex dorsally; prothorax in dorsal view with cervix well developed; pronotal shoulders moderately to well developed, rounded or sharp; posterior margin of pronotum (in front of mesoscutum) usually with row of large crenulae or pits; side of pronotum flat or moderately concave, smooth and glabrous, with distinct pilosity along dorsal and anterior margins; epomium usually well developed, at least its lower part; spiracle on prothorax moderately to distinctly tubelike protruding; propleuron in lower half (above forecoxa) often with field carinate on all sides, propleuron generally densely hairy; mesoscutum about as long as wide, moderately to distinctly convex, with long scattered semierect setigerous punctures, exceptionally rarely with dense, fine longitudinal microsculpture; parapsidal and anterior parallel lines not developed; notaulus percurrent, deep, often slightly sinuate, noncrenulate, deeply pitted anteriorly, often dilated posteriorly, contiguous with transscutal articulation, very rarely notaulus abbreviate; humeral and suprahumeral sulci never developed; anterior scutellar pit large, always bifoveate, foveae separated by septum of various 
widths; scutellar disc subquadrate, with sharp lateral keels, posterolateral corners of disc sometimes sharply pointed, axillar pit usually not developed, lateral pit always developed, deeply impressed, posterior scutellar pits present in various configurations, usually two, or, rarely absent; posterior margin of axilla at most slightly arcuate, slanted diagonally, sharply bent; axillar depression relatively small, deep, with abundant pilosity; mesopleuron only slightly convex, smooth, shining and predominantly glabrous; median oblique depression not developed; epicnemial pit moderately to strongly developed, epicnemial carina well developed, rarely crenulate ventrally; sternaulus strong, percurrent, noncrenulate, in few species only weakly developed, posterior margin of mesopleuron smooth, noncrenulate; metanotum moderately developed, dorsellum with three low longitudinal keels; metapleuron rough rugulose, densely hairy; propodeum relatively long; median keel replaced by inverted Vshaped carina, rarely pointed anteriorly, plica developed or obscured by rough rugulosity; posterior margin of propodeum deeply excavate, posterolateral corners moderately to strongly projecting; nucha very short, usually concealed under anterior rim of petiole; female forewing always with longitudinal fold and apical excision, male forewing with or without fold or excision; forewing almost veinless, submarginal vein incomplete, reduced to short basal stem; marginal cilia in forewing moderately long; hind wing without tracheate submarginal vein; legs moderately elongate, especially trochanters; femora distinctly clavate, median and especially hind femur with moderate to distinct flaps. METASOMA. Metasoma long and pedunculate, petiole cylindrical, moderately to distinctly longer than wide (up to six times), with strong longitudinal carinae, glabrous dorsally, hairy ventrally and at sides, without distinct flap anteriorly; metasoma past petiole long and ovoid; anterior margin of T2 (macrotergite) with long deep median cleft, flanked sometimes with shallow lateral depressions, cleft very rarely absent; following tergites extremely short and compact, apical tergite frequently flexed under, not visible dorsally; S2 usually with two deep longitu- dinal grooves filled with pilosity in basal part.

ReCognition AND Relationships: Coptera was previously confused with Psilus (= Galesus); Muesebeck (1980) emphasized the shape of the occiput and the reduction of venation in the forewing along with the ratio of A3 and A4 in the male antenna as the principle characteristics of Coptera. Unlike Psilus, no Coptera species are known to be apterous or brachypterous. Coptera differs from Ortona by the structure of the mandibles and the structure of the female antennal clava, and from Aneuropria by the deeply notched anterior margin of T2 (macrotergite).

DISTRIBUTION: This is a large genus of almost worldwide distribution. Unlike Psilus the members of Coptera are predominantly tropical. Muesebeck (1980) recognized 29 Nearctic species; only a few Neotropical species are known, but we estimate that a potential of 150 species exists.

BIOLOGY: Several species were reared from various dipterous hosts (Muesebeck, 1980); the most frequently attacked families include the fruit flies (Tephritidae), hereby demonstrating the importance in biocontrol (Loiácono, 1981; Silvestri, 1914). Species are encountered in a multitude of habitats, from lowlands to highlands. Several species were collected in light traps in Brazil but none associated with ants.

\section{Ortona, new genus}

Figures 78, 79

Diagnosis $(q \delta)$ : Small to medium-sized (1-3.5 mm) individuals; body color deep black with appendages usually lighter; body predominantly smooth, highly shining, relatively glabrous, with no hairy cushions or foamy structures; mandible relatively small not protruding, tightly clasped, bidentate; labrum exposed, sclerotized; antennal formula 11-13, A11 in female remarkably enlarged, A4 in male not modified; forewing almost veinless; anterior margin of T2 (macrotergite) with long median cleft.

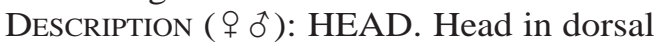
view transverse, subrectangular, with shelf and toruli moderately protruding; temple distinctly shorter than length of eye; head in lat- 
eral view moderately to distinctly depressed, always distinctly wider than high, antennal shelf moderately developed, almost effaced between toruli; level of torulus at midpoint of eye; eye subellipsoidal, with long scattered pilosity; oral carina only moderately developed; postgenal cushion not developed; occipital flange broad, always crenulate; head in frontal view with face broad, clypeus almost flat, epistomal sulcus well developed; labrum exposed, sclerotized, strongly transverse; anterior margin of clypeus not projecting, not flexed; malar sulcus not developed, malar space between lower eye orbit and mandibular condyle extremely narrow; tentorial pit moderate; mandible relatively small, not protruding, tightly clasped, bidentate; palpi relatively short, especially labial palpus, palpal formula 5-2; head in ventral view with hypostomal bridge not developed; antennal formula 11-13; A1 cylindrical, relatively long, apical rim not excavate ventrally, not produced into flaps; female clava abrupt, one-segmented (A11), long ovoid, only moderately flattened ventrally, without ventral pit; male antenna filiform, with moderately long, nonverticillate hairs, A4 not modified, without carina. MESOSOMA. Mesosoma moderately long, distinctly to remarkably wider than high, strongly flattened dorsally, mesoscutum, scutellum and propodeal keel almost at same level; prothorax in dorsal view with cervix moderately developed, pronotal shoulders moderately to distinctly rounded; side of pronotum moderately concave, smooth, shining and glabrous, with distinct pilosity only along anterior margin; epomium developed at least in vertical part, rarely epomium sharply angular with horizontal carina; spiracle on pronotum long, spikelike; propleuron in lower half (right above forecoxa) with smooth glabrous subrectangular field carinate on all sides, remaining part of propleuron hairy; mesoscutum almost semicircular, wider than long, with only few scattered hairs; parapsidal and anterior parallel lines absent; notaulus percurrent, deep, strongly arcuate, noncrenulate, nondilated posteriorly, usually separate from transscutal articulation by narrow septum; humeral and posthumeral sulci weakly developed or absent; anterior scutellar pit large, bifoveate, fovea separated by septum of var- ious widths; scutellar disc subquadrate, with sharp lateral keels, axillar and lateral pits deeply impressed, posterior scutellar pits not developed; posterior margin of axilla sharp, strongly slanted diagonally; axillar depression relatively small, deep, with abundant pilosity; mesopleuron only slightly convex, smooth, shining and glabrous; median oblique depression not developed; sternaulus strong, broad, percurrent; epicnemial pit almost absent; epicnemial carina strong, noncrenulate, connecting ventrally (above mid coxa) with posterior apex of sternaulus; posterior margin of mesopleuron smooth, noncrenulate; metanotum relatively narrow; dorsellum weakly developed, narrow, with three low longitudinal keels; metapleuron rough rugose, entirely hairy; propodeum remarkably long and large; median keel strongly developed but not pointed anteriorly; plica well developed, space between plica and median keel perfectly smooth and glabrous; posterior margin of propodeum deeply excavate, margin rimlike, posterolateral corners moderately to distinctly projecting; side of propodeum rough rugose and hairy; nucha relatively short; forewing with apex rounded, not excised (i.e., without longitudinal fold), venation almost entirely absent, only short tracheate stem of submarginal vein present, lower half of wing with long crescentic whitish glabrous line, marginal cilia including foremargin of wing relatively long; hind wing without tracheate submarginal vein; legs moderately elongate, especially trochanters, femora distinctly clavate in posterior half. METASOMA. Metasoma long pedunculate; petiole cylindrical, moderately to distinctly longer than wide (up to 3 times), with strong, longitudinal carinae, glabrous dorsally, hairy ventrally and at sides, without distinct flap anteriorly; metasoma past petiole long ovoid; anterior margin of T2 with long, deep median cleft, T2 (macrotergite) extremely long, smooth and glabrous, following four tergites extremely narrow and compact, apical tergite relatively large, bluntly triangular in female, more rounded in male; base of S2 with one or two longitudinal keels; apical sternite, especially in female, expanding at sides, well visible in dorsal view, entire surface rough-punctate.

TYPE SPECIES: Ortona hansoni, new spe- 
cies (described below), by present designation.

RECOGNITION AND RELATIONSHIPS: Ortona is compared best with Aneuropria Kieffer and Coptera Say. With the former it shares normally clasped mandibles and unarmed A1, but differs from it principally by the antennal formula and by the structure of the antennal clava in the female, furthermore by the deeply grooved anterior part of T2. From Coptera it differs primarily by the normally clasped mandibles, unarmed A1, also by the antennal formula. Ortona belongs to the tribe Psilini mainly because of the exposed sclerotized labrum, formation of a true macrotergite 2 of the metasoma, and the reduction of wing venation in the forewing.

ETYMOLOGY: The name is an arbitrary euphonic combination of letters; the gender is feminine.

DistRIBUTION: About 10 species are known to us in the New World, from Arizona to Brazil; individuals are relatively rare in the collections.

BIOLOGY: Unknown; most individuals were collected in tropical rainforest.

Ortona hansoni, new species

Figures 78, 79

DESCRIPTION: Holotype, $q$ : Length 2.2 $\mathrm{mm}$; head, mesosoma (including tegula and coxae), and metasoma deep black, palpi, A1A3, legs (except coxae) orange-yellow, wings almost clear, with light yellowish tinge.: HEAD. Head in dorsal view wider than long (43:32); ocelli in very low triangle LOL:OOL $=4: 6$; crenulae on occipital flange largest in middle, crenulae diminishing toward sides; temple distinctly shorter than length of eye (8:15), strongly receding posteriorly; toruli separated by narrow space, subequal to half their diameter; head in lateral view slightly longer than high (32:29); eye distinctly higher than long $(22: 15)$, remarkably larger than malar space $(22: 3)$, distinctly longer than postgena $(15: 8)$; head in frontal view with face slightly convex, smooth, with few large setigerous punctures; space between toruli only slightly emarginate; epistomal sulcus well developed; tentorial pits large; clypeus along epistomal sulcus with three large setigerous punctures; anten- nal segments in relative proportions (25:6), (7:5), (8:4), (8:4), (8:4.5), (8:5), (8:5), (8:5), $(7: 5.5),(7: 6.5),(24: 9)$. MESOSOMA. Mesosoma longer than wide (79:50); horizontal part of epomium not developed, shoulder rounded, vertical part of epomium simple, carinate, noncrenulate; pronotal shoulder distinctly rounded; posterior apex of notaulus not reaching transscutal articulation, space in between notauli subequal to maximum width of notaulus; humeral sulcus fine but distinctly impressed, suprahumeral sulcus not developed; anterior scutellar pits positioned diagonally, strongly converging anteriorly, septum between them as wide as width of axillar pit; posterolateral corners of scutellar disc (i.e., lower margin of lateral pits) not projecting. METASOMA. Petiole distinctly elongate (34:14); dorsal side of petiole with three strong longitudinal keels enclosing two depressions with fine irregular transverse microsculpture; median cleft on T2 not exceeding basal third of tergite (20:73).

MALE: Differs from female in following character states: A1 and A2 reddish orange, distinctly lighter than rest of antenna; antennal segments in relative proportions (26:6), (8:6), (11:5.5), (13:5.5), (13:5.5), (13:5.5), (13:6), (12:6), (12:6), (12:6), (11:6.5), (11:7), (16:7); A3-A13 with semierect dense hairs, hairs slightly shorter than maximum width of antennomeres; A3-A13 with fine irregular pustulate surface; anterior scutellar pits larger than in female, septum between them narrower, smaller than maximum width of axillar pit; apical sternite distinctly excavate.

Type Material: $10 q 0$. Holotype, $q$ (CNCI no. 22459), COSTA RICA, Puntarenas Prov., San Vito, Estación Biológica Las Alturas, 1500 m, November 1991, P. Hanson, MT. Allotype, o, same data as holotype, but caught February 1992. Paratypes, 6ㅇ, 20, same data as holotype, but some caught from January to October (CNCI, MIZA, BNMH).

ETYMOLOGY: The species is named in honor of Dr. Paul Hanson (Universidad de Costa Rica) in recognition of his pioneering work in surveys of microhymenoptera in Costa Rica.

Distribution: Costa Rica.

BIOLOGY: Unknown. The type series was collected in a cloud forest.

VARIATION: Very little variation was ob- 
served in the type series; the three males are slightly larger than the females.

\section{Psilus Panzer}

Figure 89

Psilus Panzer, 1801: 11.

Galesus Haliday, 1829.

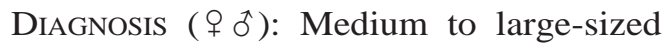
(3-6 $\mathrm{mm})$ individuals, rarely body size smaller (about $2 \mathrm{~mm}$ ); body color deep black with appendages sometimes lighter, body predominantly smooth, highly shining, with abundant pilosity, usually with hairy cushions but no foamy structures; occiput gradually rounded posteriorly, not steplike; labrum exposed, sclerotized, sharply triangular; oral carina moderately to strongly developed, permitting movement of mandible only along vertical axis; mandible long, falcate, bidentate, distinctly projecting diagonally backward (opisthognathous); antenna apparently capable of rotation in socket, permitting variable positions; A1 in both sexes relatively short, subtriangular, with sharp ledge on outer side, always with distinct flaps apically; male A3 moderately to distinctly shorter than A4; forewing in both sexes never folded longitudinally, without apical emargination, with tracheate but clear (depigmented) submarginal vein, vein knobbed apically, not reaching foremargin of wing; T2 (macrotergite) with deep median cleft.

DESCRIPTION ( $q$ ô): HEAD. Head in dorsal view usually moderately to distinctly elongate, with shelf and toruli strongly protruding, shelf typically forming sharp membrane often notched or sinuate medially; frons always armed with projections, points, ledges or carinae; vertex gradually sloping into occiput, without step; temple moderately to distinctly longer than length of eye; head in lateral view remarkably subtriangular; antennal shelf strongly projecting forward; level of torulus at lower half of eye; eye relatively small, subellipsoidal, always higher than long, usually smaller in female; oral carina strongly developed, semicircular, bladelike, permitting movement of mandible only along vertical axis; postgenal cushion usually well developed, rarely reduced; occipital flange moderately developed, usually noncrenulate; head in frontal view with face long, strongly convex medially, depressed laterally; clypeus highly convex, as high as wide or higher; epistomal sulcus weakly developed; labrum exposed, sclerotized, sharply triangular; malar sulcus not developed; gena between lower eye orbit and mandibular condyle distinctly to moderately shorter than eye height; tentorial pit large; mandible long, falcate, bidentate, mandible distinctly projecting diagonally backward (opisthognathous), apical tooth usually strongly curved inward; palpal formula 5-2; head in ventral view with hypostomal bridge not developed; antennal formula 12-14; A1 relatively short, subtriangular, with sharp ledge on outer side, with no additional sharp projections below, always with distinct flaps apically; female antenna with nonabrupt multisegmented clava, clavomeres rarely flattened apically, A12 usually largest and longest, with or without ventral pit; male antenna filiform, A3-A14 with dense moderately long nonverticillate hairs, A3 moderately to distinctly shorter than A4, A4 moderately constricted basally, without carina. MESOSOMA. Mesosoma moderately to distinctly long, usually as wide as high, flattened to only moderately convex dorsally; prothorax in dorsal view with cervix well developed; pronotal shoulders at most moderately rounded; posterior margin of pronotum (in front of mesoscutum) noncrenulate, usually densely hairy; side of pronotum almost flat or weakly concave medially, smooth and glabrous, with distinct pilosity along anterior and dorsal margins; epomium not developed; spiracle on prothorax moderately tubelike; propleuron in lower half (above forecoxa) without carinate field, generally densely hairy; mesoscutum about as long as wide, at most moderately convex to flattened, with relatively few scattered semierect hairs; parapsidal and anterior parallel lines not developed; notaulus percurrent, deep, noncrenulate, usually narrow, not dilated posteriorly, almost contiguous with transscutal articulation; humeral and suprahumeral sulci not developed; anterior scutellar pit large, always bifoveate, foveae strongly converging anteriorly, separated by narrow septum; scutellar disc subquadratic to subcircular, with sharp lateral keels, posterolateral corners of disc rounded; axillar pit never developed; lateral pit always developed, posterior scutellar pit 
present, sometimes reduced to transverse row of slits; posterior margin of axilla at most slightly arcuate, slanted diagonally, sharply bent; axillar depression relatively small, deep, with abundant pilosity, usually with dense tuft of hairs in posterior corner (below posterolateral corner of scutellar disc); mesopleuron only slightly convex, smooth, shining, part above sternaulus almost glabrous; median oblique depression not developed; epicnemial pit moderately to strongly developed, epicnemial carina moderately developed, noncrenulate ventrally; sternaulus strong, percurrent, noncrenulate; posterior margin of mesopleuron usually smooth, rarely partly or entirely crenulate; metanotum moderately developed; dorsellum with three low longitudinal keels; metapleuron rough rugulose, densely hairy; propodeum relatively long; median keel replaced by inverted Vshaped carina, rarely pointed anteriorly, plica developed or obscured by rough rugulosity; posterior margin of propodeum excavate posterolateral corners moderately to strongly projecting; nucha short, concealed under anterior rim of petiole; forewing in both sexes never folded longitudinally, without apical emargination, with tracheate but clear (depigmented) submarginal vein, vein knobbed apically, slanted diagonally, not reaching foremargin of wing; basal vein often indicated as nebulous arc; submarginal vein in hind wing incomplete, hyaline or absent, with only short basal tracheate stem; wings very rarely shortened or absent; legs moderately elongate, trochanters in particular, femora distinctly clavate, with no flaps apically. METASOMA. Metasoma long and pedunculate, petiole cylindrical, moderately elongate to distinctly longer than wide (up to 2.5 times), with strong longitudinal carinae, glabrous dorsally, hairy ventrally and at sides; metasoma past petiole long and ovoid; anterior margin of T2 (macrotergite) with long deep median cleft flanked sometimes with shallow lateral depressions; following tergites compact, apical tergite in female not flexed under, visible dorsally; S2 basally with hairy cushion and three shallow longitudinal depressions.

RECOGNITION AND RELATIONSHIPS: In the past, Psilus (i.e., Galesus) was confused with Coptera; Muesebeck (1980) emphasized the shape of the occiput, presence of tracheate submarginal vein in forewing and the ratio of A3 to A4 in the male antenna as the principal character states of Psilus. Psilus differs from Ortona by falcate mandibles, armed A1, and the structure of the female antennal clava; from Aneuropria furthermore by the deeply notched anterior margin of $\mathrm{T} 2$.

DISTRIBUTION: This is a large genus represented primarily in the Northern Hemisphere, with no members in the Neotropical and Australian regions. Muesebeck (1980) recognized 17 Nearctic species.

BIOLOGY: The biological ground plan is primary parasitism of Diptera, but only a few positive host records exist (Muesebeck, 1980).

\section{TRIBE SPILOMICRINI ASHMEAD 1893}

Diagnosis: Mostly medium-sized, less frequently minute or large individuals, usually with only moderate pilosity and only rarely with foamy structures; labrum either exposed or concealed; hypostomal bridge absent, rarely (secondarily) developed; malar sulcus present or absent; antennal formula most frequently $13-13$, rarely $12-13$, exceptionally $14-14$, female clava generally nonabrupt, male antenna nonverticillate; notaulus typically percurrent, less frequently abbreviate or absent; anterior scutellar pit variable, single, bifoveate, tripartite or replaced by arc of minute crenulae, lateral and posterior scutellar pits usually present; epicnemial pit usually developed, often filled with dense pilosity, rarely reduced; epicnemial carina often crenulate, bordering epicnemial pit, sternaulus often developed; submarginal vein in forewing relatively long, distinctly exceeding basal third of wing length, vein distinctly to remarkably remote from foremargin, costal cell relatively wide, costal vein often well developed, less frequently depigmented or absent, marginal and stigmal veins well developed, postmarginal vein rarely developed, basal vein often developed, usually nebulous, tending toward submarginal vein distinctly before marginal vein; large tergite of metasoma composed of fused T2 + T3, i.e., syntergite.

REMARKS: This is the second largest tribe of the subfamily with 12 genera recognized 
in the New World (Bruchopria Kieffer, Chilomicrus, new genus, Doddius, new genus, Entomacis Foerster, Epomium, new genus, Ferrugenus, new genus, Idiotypa Foerster, Paramesius Westwood, Pentapria Kieffer, Poecilopsilus Ogloblin, Spilomicrus Westwood, and Xenismarus Ogloblin). Although habitually quite cohesive, the tribe remains defined mostly on characters of plesiomorphic conditions. Xenismarus and Chilomicrus are perhaps the most primitive genera, with antennal formula 14-14. The absolute majority of the tribe has antennal formula 1313 , which is quite unique in the entire subfamily. Wing reduction in both sexes is frequent among the Spilomicrini. The biological ground plan is with dipterous hosts; no highly specialized myrmecophiles are known among the members of this tribe and no species seem to enter aquatic habitats.

\section{Bruchopria Kieffer \\ Figures 23, 24}

Bruchopria Kieffer, 1921: 38.

Aulatopria Brèthes, 1927a: 163. NEW SYNONYMY.

Diagnosis ( $q \hat{\jmath}$ ): Medium-sized (2.5-2.7 $\mathrm{mm}$ ) individuals; body light to dark brown, legs and antenna lighter, body smooth and highly shining with abundant pilosity and unique fine velvety upright micropilosity on propodeum and petiole; foamy structures not developed; antennal formula 13-13; female clava nonabrupt, multisegmented; male A3 subequal to or longer than A4; pronotum posteromedially (in front of mesoscutum) strongly raised, sharply carinate; scutellum without any pits; metapleuron and propodeum covered with velvety, dense, fine upright micropilosity; submarginal vein in forewing considerably remote from foremargin of wing; petiole very short and broad, transversely subrectangular, covered with velvety, dense, fine upright micropilosity; anterior margin of syntergite not notched medially.

DESCRIPTION ( $q$ o $)$ : HEAD. Head in dorsal view globose, frons unarmed; antennal shelf well developed in front of toruli; temple very long; head in lateral view slightly higher than long; antennal shelf moderately projecting; level of toruli at midpoint of eye; eye remarkably small, distinctly shorter than malar space, subcircular, with small ommatidia; oral carina not developed; outer margin of postgena with dense hairy cushion; occipital flange present but narrow and not steplike, noncrenulate; head in frontal view with clypeus almost flat, epistomal sulcus indicated by relatively deep depression; labrum not exposed; malar sulcus not developed, area between lower orbit and mandibular condyle large; tentorial pit not developed; mandible clasped, strong, bidentate, lower tooth longer; palpi very short, palpal formula 4-2; head in frontal view with hypostomal bridge not developed; antennal formula 13-13; scape long, cylindrical, with apical rim only moderately excavate ventrally, rim not produced into flaps; female clava nonabrupt, multisegmented, clavomeres not flattened ventrally, A13 without ventral pit; male A3 subequal to or longer than A4, A3 and particularly A4 sexually modified, A5-A13 very short, almost beadlike, subclavate. MESOSOMA. Mesosoma moderately elongate, as high as wide, moderately convex dorsally; prothorax in dorsal view strongly developed both medially and at sides; cervix strongly developed; pronotal shoulders almost rectangular but rounded at corners; pronotum posteromedially (in front of mesoscutum) strongly raised, sharply carinate, slightly notched medially (better seen in lateral view); side of pronotum moderately convex, smooth and shining, with few scattered hairs, with only moderate strip of denser pilosity along anterior margin; epomium not developed; mesoscutum almost as long as wide, moderately convex, with scattered long erect hairs; parapsidal and anterior parallel lines not developed; notaulus not developed; humeral and posthumeral sulci not developed; scutellum without any pits, scutellar disc only slightly convex, without median keel, lateral keels indistinct; axillar carina strongly developed, almost bladelike; posterior margin of axilla rounded, axillar depression small, shallow, weakly defined; mesopleuron only moderately convex, smooth, shining, with only few scattered hairs; median oblique depression not developed; epicnemial pit minute; sternaulus not developed; posterior margin of mesopleuron smooth, noncrenulate; metanotum moderately developed, dorsellum with three short longitudinal keels; metapleuron covered with velvety fine, 
upright, dense micropilosity; propodeum relatively large but short, covered with dense fine velvety upright micropilosity, median keel shortly raised anteriorly; plica not developed; posterior margin of propodeum not rimlike, with posterolateral corners blunt; nucha extremely short; wing relatively long and narrow, distinctly surpassing tip of metasoma, apex round, with moderate marginal cilia; submarginal vein in forewing not exceeding basal third of wing length, vein considerably remote from foremargin of wing; marginal vein short, almost wedgelike; stigmal vein rudimentary, no other veins present; submarginal vein in hind wing incomplete, hyaline; wings often bitten off by ants; legs relatively long and strong; hind tibia gradually incrassate toward apex. METASOMA. Metasoma short, pedunculate; petiole very short and broad, transversely subrectangular, covered with velvety dense fine, upright micropilosity, smooth, without longitudinal keels; anterior margin of syntergite as wide as petiole, not notched medially, syntergite and following tergites covered with numerous long, semierect, golden hairs.

TyPE SPECIES: Bruchopria pentatoma Kieffer.

ReCognition and Relationships: Among the genera of Spilomicrini, Bruchopria is unique principally because of the fine velvety pilosity of the metapleuron, propodeum, and petiole. The carinate posteromedian margin of pronotum is also peculiar to Bruchopria. The latter two apomorphies are interpreted as adaptations for association with host ants. Within the Spilomicrini, Bruchopria is closest to Spilomicrus, from which it also differs by the structure of the scutellum which is devoid of all pits. Aulatopria is presently made junior synonym of Bruchopria (see above) (types examined).

Distribution: Two species are known from South America (Argentina, Brazil, Uruguay): $B$. pentatoma Kieffer and B. tucumana (Brèthes), new combination.

BIOLOGY: The type species was observed among fire ants (Solenopsis richteri Forel and Solenopsis sp.), the second species was reared from pupae of Billaea claripalpis (Wulp) (Diptera, Tachinidae).
Chilomicrus, new genus

Figures 32, 33

Diagnosis $(q \hat{\phi})$ : Medium to large-sized (2-4 $\mathrm{mm})$ individuals; body color predominantly brownish, mesosoma frequently lighter than head and metasoma, reddish brown to almost orange, sometimes partly black, appendages usually lighter than rest of body; head and mesosoma predominantly smooth and shining but frequently with large deep setigerous punctures, body with abundant pilosity but no distinct hairy cushions and no foamy structures; labrum not exposed; antennal formula 14-14; A1 with moderate flaps apically; epomium not developed; anterior scutellar pit subreniform, not clearly divided medially; axillar and lateral pits of scutellum not developed; sternaulus at most weakly developed; forewing with basal vein tracheate, vein straight, nonarcuate, perpendicular to submarginal vein; anterior margin of syntergite with deep long median cleft.

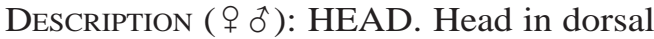
view subrectangular to subquadrate, slightly wider than long, with shelf and toruli strongly projecting; toruli connected with carina, carina sometimes with slight median declivity; temples subequal to or longer than length of eye; head in lateral view with antennal shelf well developed; level of toruli at lower half of eye; eye ovoid, slightly higher than long, with long pilosity; oral carina not developed; postgenal cushion not developed; occipital flange moderate to minute, rarely with indication of crenulae; head in frontal view with face moderately elongate; clypeus moderately to distinctly convex, relatively small, subcircular; epistomal depression shallow; anterior margin of clypeus relatively narrow, straight, not flexed; labrum not exposed; malar sulcus usually not developed; lower gena typically without striae, in one species with short fan of striae; tentorial pit absent; mandible short, strong, bidentate, lower tooth longer than upper tooth, lower margin of mandible (from condyle to tip) moderately to distinctly arcuate; mandibular condyle broad, strong; palpi long and slender, palpal formula 5-2; head in ventral view with hypostomal bridge not developed; antennal formula 14-14; A1 long and slender; apex with moderate flaps, distinctly emargin- 
ate ventrally; base of A2 in both sexes strongly compressed between A1 flaps; female antenna with moderate to strong, nonabrupt, multisegmented clava (4-5), clavomeres progressively thickened, moderately to distinctly flattened ventrally, A14 always largest and longest, without ventral pit; male antenna filiform, with moderately long scattered nonverticillate hairs, A3 slightly longer than or subequal to A4 in length, A4 moderately constricted basally, with distinct longitudinal carina. MESOSOMA. Mesosoma moderately robust, slightly wider than high, slightly to distinctly flattened dorsally; prothorax in dorsal view with distinct cervix, shoulders prominent but rounded; side of pronotum moderately concave, mostly smooth and glabrous, with more distinct pilosity along anterior margin; epomium not developed; posterior margin of pronotum (between forecoxa and spiracle) noncrenulate, at most with setigerous punctures; lower part of propleuron (right above forecoxa) often with raised carina or irregular crenulae, glabrous, upper part of propleuron hairy; mesoscutum semicircular, moderately to distinctly wider than long, smooth and shining, often with deep scattered setigerous punctures, punctures sometimes very large; parapsidal and anterior parallel lines usually present as weak to moderate depressions; notaulus percurrent, arched, not distinctly dilated posteriorly, noncrenulate, not directly contiguous with transscutal articulation; humeral and suprahumeral sulcus extremely narrow, humeral sulcus sharply rimed externally; anterior scutellar pit subreniform, not clearly divided medially; scutellar disc flat, subquadratic, with lateral keels weakly prominent, axillar pit not developed, lateral pit not developed, usually obscured by deep setigerous punctures; posterior scutellar pits usually crenulate; posterior margin of axilla rounded, axillar depression large and hairy, axillar keel relatively well developed, sharp; mesopleuron almost flat, only slightly convex, smooth shining, predominantly glabrous, median oblique depression not defined; epicnemial pit moderate to strongly developed, with abundant pilosity; sternaulus usually not developed, sometimes rudimentary (posterad epicnemial pit), rarely weakly developed; posterior margin of mesopleuron partly to entirely crenulate; metanotum relatively strongly developed; dorsellum only moderately projecting with three short longitudinal keels and abundant pilosity; metapleuron rough rugulose and with dense pilosity; propodeum relatively long; median keel moderately to distinctly raised medially, pointed; plica usually well developed; posterior margin of propodeum sharply excavate medially with four blunt corners (upper and lower ones) posterolaterally; propodeum intensely hairy dorsally and laterally; nucha moderately well developed; forewing relatively long, rounded apically, with moderately long marginal cilia; wing venation in forewing distinctly surpassing basal third of wing length; costa and submarginal vein strongly developed, tracheate, costal cell moderately wide, marginal vein moderately to distinctly elongate, stigmal and postmarginal vein short, together enclosing sharp angle; postmarginal vein sometimes strongly reduced; basal vein tracheate, straight, nonarcuate, perpendicular to submarginal vein; posterior part of $M$ vein sometimes tracheate (near foot of basal vein); other veins at most lightly nebulous; hind wing with tracheate submarginal vein, basal cell not developed; wings sometimes shortened, not exceeding base of metasoma; legs moderately long, femora distinctly clavate, apex of foretibia (on dorsal side) usually with strong curved spine. METASOMA. Metasoma short, pedunculate; petiole slightly elongate, cylindrical, usually with irregular longitudinal ridges and abundant pilosity on all sides, with only moderate anterior flap; metasoma past petiole moderately elongate, considerably flattened dorsally, anterior margin of syntergite with deep long median cleft, cleft usually flanked by short lateral emarginations; apex of metasoma in female short and pointed; apical sternite short, flat, bluntly triangular; base of S2 sometimes with two or three deep grooves basally.

TYPE SPECIES: Chilomicrus pecki, new species (described below).

RECOGNITION AND RELATIONSHIPS: Chilomicrus may be placed at the base of the tribe Spilomicrini largely because of its most plesiomorphic antennal formula (14-14). However, the perpendicular basal vein in the forewing is considered a unique, highly derived 
state of wing venation, conveniently distinguishing this new genus from all members of the Spilomicrini. Among the genera of Spilomicrini, Chilomicrus differs from Pentapria also by the structure of the anterior scutellar fovea, the structure of the side of the pronotum, and by the relatively high pointed median keel of the propodeum. From Epomium and Ferrugenus it differs principally by the absence of the epomium and the lack of closed cell in hind wing.

ETYMOLOGY: From chilo, in reference to Chile; and micros, in reference to Spilomicrus. The gender is masculine.

DistribUTION: The present known distribution of the genus is in the Valdivian forest of Chile; one Chilean species is known to us from the dry Coquimbo region. Altogether we examined approximately 10 undescribed species (CNCI).

BIOLOGY: Unknown.

\section{Chilomicrus pecki, new species}

Figures 32, 33

DESCRIPTION: Holotype, ô: Length 3.6 $\mathrm{mm}$; body distinctly bicolored, head and metasoma past petiole predominantly black, mandible, clypeus, antennal shelf, palpi, mesosoma, petiole antenna, and legs including coxae reddish brown; mesopleuron (especially median part) dark brown; forewing slightly infuscate especially in median part (below stigmal vein), basal vein distinctly pigmented. HEAD. Head in dorsal view slightly wider than long (68:61, shelf included), subrectangular, with scattered setigerous punctures; OOL distinctly longer than LOL (13:5); temple only moderately bulging, shorter than eye (19:23), only moderately receding; toruli connected anteriorly by shelf, shelf very lightly sinuate medially, gap between toruli shorter than diameter of torulus; head in lateral view slightly higher than long (67:61), eye moderately higher than long (34:23); eye height: malar space (34:15); head in frontal view with vertex distinctly topped around ocellar triangle, outer margin of gena slightly bulging; antennal shelf medially with irregular transverse rugulosity; A1 entirely smooth without microsculpture, with scattered setigerous punctures; antennal segments in relative proportions $(55: 10),(11$ :
8), (31:8), (24:9), (21:8), (21:7.5), (21:7.5), (20:7.5), (21:7.5), (21:7.5), (21:7), (21:7), (20.5:7), (31:6.5); hairs on A3-A14 shorter than width of antennomeres; A4 with sharp longitudinal keel exceeding basal half of segment. MESOSOMA. Mesosoma longer than wide (130:85); pronotum dorsally densely hairy, hairs not forming cushion; side of pronotum moderately concave with abundant pilosity dorsally and anteriorly, with moderate setigerous punctures on margin and shoulder, with single deep pit diagonally below spiracle, with several longitudinal rugae above forecoxa and with three deep setigerous punctures along posterior margin; propleuron with irregular rugose crenulae above forecoxa, propleuron predominantly smooth in upper part; mesoscutum with parapsidal line deeply impressed, groovelike; anterior parallel lines not developed; notaulus only indistinctly broadened basally, not contiguous with transscutal articulation; median lobe and scapulae with very few medium-sized setigerous punctures; anterior scutellar pit as wide as space between outer margins of notauli; axilla with 4-5 larger setigerous punctures; posterior margin of mesopleuron with 4-5 transverse crenulae in lower half; propodeum in dorsal view with median keel extending posteriorly to basal third and here forked; space between median keel and plica with dense appressed pilosity; posterior margin of propodeum with posterolateral corners projecting but not pointed; apex of foretibia dorsally with distinct curved spine. METASOMA. Petiole only moderately elongate (35:23), with irregular longitudinal rugulosity, with slightly pointed protuberance on each side in anterior third; metasoma past petiole longer than wide (115:71); cleft on anterior base of syntergite not exceeding basal third of syntergite, anterolateral corners of syntergite with short hairy incision; posterior margin of syntergite without micropunctures, with two rows of long semierect hairs; following tergites with one row of hairs each.

FEMALE: Unknown.

TYPE MATERIAL: 26 0 . Holotype, ô (CNCI no. 22451), CHILE, Alto de Vilches, $70 \mathrm{~km}$ E Talca, December 5, 1984-February 20, 1985, S. \& J. Peck, Nothofagus forest, FIT, $1300 \mathrm{~m}$. Paratypes, 25 $\hat{0}$, same data as holotype (AMNH, BMNH, CNCI, MIZA). 
ETYMology: The species is named in honor of Dr. S. B. Peck (Carleton University, Ottawa) who collected many diapriid wasps in Chile.

DisTRIBUTION: Chile (Valdivian forest).

Biology: Unknown.

VARIATION: Considerable variation exists in crenulation of posterior margin of mesopleuron; extreme cases are specimens with crenulae indicated only at base to those with margin entirely crenulate.

\section{Doddius, new genus}

Figures 39, 40

DiAgnosis ( 9 ô): Large individuals (4-6 $\mathrm{mm}$ ); body color from light to dark brown, rarely parts of body reddish, body sculpture often rough rugose (head, mesosoma, petiole), less frequently smooth, with abundant pilosity, but no hairy cushions or foamy structures; antennal shelf not developed, toruli separated by gap, in some species toruli almost contiguous but not connected by carina; cheek and gena with fan of strong striae reaching lower orbit, striae obscuring malar sulcus; forewing with marginal vein remarkably elongate, vein longer than its distance from junction of basal and submarginal veins; marginal vein 3.3-5.5 times longer than stigmal vein; petiole remarkably elongate, pencil-like, slightly shorter (females) or longer (males) than rest of metasoma; anterior margin of syntergite with deep slit or emargination medially.

DESCRIPTION ( $q$ o $)$ : HEAD. Head in dorsal view transverse, subrectangular; temples long, distinctly rounded; toruli separated by gap or almost contiguous, not connected by carina; head in lateral view with antennal shelf not developed, level of toruli in lower half of eye; eye subovate; oral carina not developed; occipital flange narrow, sometimes crenulate; postgenal cushion not developed; head in frontal view with long face; mandible short but strong, bidentate, lower tooth distinctly longer; clypeus considerably convex, narrow, higher than wide, with anterior margin almost flexed; epistomal sulcus not defined; labrum not exposed; tentorial pits small; malar sulcus obscured by fan of strong striae radiating on cheeks and gena from tentorial pit to lower margin of eye; head in ven- tral view with hypostomal bridge not developed; palpi long and slender; palpal formula 5-2; antenna in both sexes 13-segmented; A1 elongate, distinctly longer than A3; apical rim of A1 not emarginate ventrally, female antenna usually with light nonabrupt clava, clavomeres gradually incrassate, A13 always longest and widest; male antenna filiform with scattered fine pilosity, A4 modified, usually only moderately bent, with longitudinal carina. MESOSOMA. Mesosoma generally short, as high as wide, highly convex dorsally; prothorax in dorsal view with long cervix and prominent but rounded shoulders, side of pronotum without hairy cushion, but often with very dense pilosity; epomium developed, usually obscured by rugulose sculpture; mesoscutum strongly convex; parapsidal and anterior parallel lines usually well impressed, notaulus complete, noncrenulate, deeply incised, often moderately dilated basally; humeral and suprahumeral sulci deep but narrow, usually noncrenulate; anterior scutellar pit large and deep, wider than long, with two or more longitudinal keels on bottom; scutellar disc slightly to distinctly convex with no lateral keels and no lateral scutellar pits; posterior scutellar pits well developed; posterior margin of axilla distinctly rounded, gently sloping into shallow axillar depression; mesopleuron moderately convex, with moderate median oblique depression; epicnemial pit large, often rugose; sternaulus often developed, but sometimes replaced by rough rugosity; posterior margin of mesopleuron (above mid coxa) with row of crenulae or transverse pits; metanotum relatively broad, dorsellum usually with three subequal keels obscured by dense pilosity, median keel rarely produced into long spine; metapleuron distinctly rugose, partly hairy; propodeum generally hairy, in dorsal view moderately elongate, with median keel and posterolateral corners only slightly elevated; plica not developed; posterior margin of propodeum not distinctly rimed; nucha short; forewing long and large, usually infuscate, and/or maculate, rounded apically, with fairly long marginal cilia; costa often less pigmented than submarginal vein, costal cell relatively broad; marginal vein remarkably elongate, 3.3-5.56 times longer than stigmal vein, slightly longer than section of submar- 
ginal vein from junction with basal vein; stigmal vein short, slightly slanted toward marginal vein; postmarginal vein rudimentary; basal vein tracheate, not arcuate, joining submarginal vein at acute angle; posterior part of $M$ vein (past basal vein) tracheate up to short nebulous stem of $1 \mathrm{~m}-\mathrm{cu}$; $\mathrm{Rs}$ and $\mathrm{Cu}$ usually deeply pigmented, nebulous; hind wing with complete submarginal vein, tracheate basal vein, and nebulous continuation of $M$ vein; no short-winged or apterous forms known; legs long and slender, especially trochanter and base of femur. METASOMA. Petiole remarkably elongate, pencillike, usually slightly shorter (females) or longer (males) than rest of metasoma, anterior margin of petiole funnelled into flange partially overlapping posterior margin of nucha, surface of petiole either partly longitudinally costate or with transverse rough rugosity; anterior margin of syntergite with deep slit or emargination medially; apex of metasoma past petiole in female either blunt, with apical sternite short, or pointed, long, conical, with apical sternite strongly compressed, plow-shaped; base of S2 anterolaterally with two sharp keels flanking posterior apex of petiole.

TyPE SPECIES: Bakeria rugosa Dodd, by present designation and new combination.

RECOGNITION AND RELATIONSHIPS: Doddius is distinct among the Spilomicrini because of the strongly striate cheeks and the unusually long marginal vein in the forewing. Most species known to us exhibit rough rugose sculpture, especially on the mesoscutum and scutellum; however, we know also a number of species with these parts almost entirely smooth. Doddius is related to Entomacis (especially its primitive group of species in Chile), Poecilopsilus, and Xenismarus largely because of similar structure of mesosoma (e.g., mesopleuron), the toruli, apical rim of the A1 and the wing venation of the forewing.

ETYMOLOGY: The only known species of this genus was described by Dodd (1920) under the name Bakeria rugosa from Guerrero (Mexico). Dodd (op. cit.) indicated that the species may in fact represent an undescribed genus. It is our pleasure to dedicate this new genus in his memory; the gender is masculine.
Distribution: At present some 25 undescribed species are known to us from Central and South America (all in CNCI). Most species were collected in Costa Rica, Venezuela (including top of Auyán Tepui), and Ecuador; the northernmost point of distribution is with Doddius rugosus (Dodd) from Mexico (Guerrero), the southern limit with one frequent species in the Valdivian forest in Chile and one isolated species in eastern Brazil (Sierra Bocaina).

Biology: Hosts are unknown. Adults of Doddius are frequently encountered in moist, cool habitats such as cloud forests, upper mountain forests and paramo, in elevations from $850 \mathrm{~m}$ to over $4000 \mathrm{~m}$.

\section{Entomacis Foerster \\ Figures 48, 49, 50}

Entomacis Foerster, 1856: 121, 123.

Hemilexis Foerster, 1856: 121, 123, 127. Synonymized by Dalla Torre, 1898a.

Glyphidopria Haliday, 1857: 172. An objective junior synonym of Entomacis Foerster.

Hemilexodes Ashmead, 1893: 386, 399. Synonymized by Masner and Muesebeck in Krombein and Burks, 1967.

Adeliopria Ashmead, 1902: 15. Synonymized by Masner, 1964a:123-155.

Diagnosis ( $q$ $\delta$ ): Small to medium-sized (1-3 mm), gracile individuals; body color usually brown, rarely bright yellow-orange or almost black, smooth and highly shining; body either glabrous, without micropilosity, usually with sparse long semierect hairs dorsally, or body with abundant pilosity including dense semiappressed micropilosity at least on head; foamy structures not developed; antennal shelf not developed, toruli usually separated by gap, less frequently contiguous; anterior scutellar pit large, deep, subrectangular, without median keel, rarely with irregular longitudinal rugulosity on bottom; mesopleuron posteroventrally (above midcoxa) often with subcircular matte spot; wings usually long and slender, forewing frequently subtruncate to bilobate apically, with remarkably long marginal cilia, stigmal vein in forewing relatively very long, as long as or longer than marginal vein, slanted diagonally or almost perpendicular to marginal vein; metasoma past petiole distinctly elongate, anterior margin of syntergite very nar- 
row, subequal in width to petiole, margin straight or notched, tergites past syntergites often very narrow forming broad short triangle, tergites sometimes telescoped under syntergite.

DESCRIPTION ( $q$ o $)$ : HEAD. Head in dorsal view usually globular, rarely slightly to moderately transverse, hypognathous with frons unarmed; temple long, distinctly rounded; head in lateral view with antennal shelf not developed, toruli separated by gap, rarely contiguous, level of toruli usually in middle of eye; eye subcircular, with ommatidia relatively large and convex; oral carina rarely developed; postgenal cushion not developed; occipital flange short but sharply defined; head in frontal view with long face, mandible short but strong, bidentate; clypeus moderately convex anterior margin of clypeus often rimlike; epistomal sulcus replaced by shallow declivity; labrum not exposed; tentorial pits usually well developed; malar sulcus absent, rarely in some species weakly developed; head in ventral view with hypostomal bridge not developed; palpi slender and long, palpal formula 5-2; antenna in both sexes 13-segmented; A1 long and slender with apical rim unarmed and not emarginate ventrally; female antenna generally with light, nonabrupt multisegmented clava, rarely antennomeres 12 and 13 broadly approximated, seemingly confluent; male antenna usually filiform, A3 subequal to A4, A3-A13 with long hairs, A4 modified, usually with sharp carina. MESOSOMA. Mesosoma generally short, usually as high as wide, often highly convex dorsally; prothorax in dorsal view with cervix distinctly elongate and constricted; pronotal shoulders moderately to strongly projecting, side of pronotum without hairy cushion; epomium not developed; mesoscutum often strongly convex; parapsidal and anterior parallel lines not developed; notaulus complete, abbreviate or absent; humeral and suprahumeral sulci present or absent; anterior scutellar pit large, deep, subrectangular, without median keel, rarely with irregular longitudinal rugulosity on bottom; scutellar disc subrectangular to subquadrate, with lateral keels often sharply pointed anteriorly; lateral scutellar pits reduced or absent; posterior scutellar pits rarely developed; posterior margin of axilla rounded; axillar depres- sion large, deep usually smooth at bottom and glabrous; mesopleuron moderately convex, with moderate median oblique depression; epicnemial pit and carina present, rudimentary or absent; sternaulus not developed; mesopleuron posteroventrally (above midcoxa) often with subcircular matte spot, posterior margin of mesopleuron sometimes with row of crenulae or pits; dorsellum usually with three longitudinal keels, middle keel sometimes produced into short spine; metapleuron usually smooth and glabrous; propodeum generally hairy, in dorsal view short with median keel usually sharply projecting dorsally, posterolateral corners of propodeum usually acute, spikelike, posterior margin of propodeum rimlike, plicae well developed; wings usually long and slender, forewing frequently subtruncate to bilobate apically, with remarkably long marginal cilia, stigmal vein in forewing relatively very long, as long as or longer than marginal vein, slanted diagonally to almost perpendicular to marginal vein, marginal vein in one species not reaching foremargin of wing; forewing with costa rarely tubular, usually nebulous or absent; submarginal vein distinctly remote from foremargin of wing, distinctly surpassing basal third of wing, basal vein absent or nebulous, nonarcuate, joining submarginal vein at acute angle, posterior section of medial vein often nebulous, $\mathrm{Rs}, \mathrm{Cu}$, and posterior section of medial vein at most nebulous; hind wing with submarginal vein tubular or absent; wings may be shortened to stumps in several undescribed species; legs very long and slender, femora often subclavate in posterior half. METASOMA. Metasoma relatively slender and elongate, distinctly overlapped by wings; petiole moderately to distinctly elongate, cylindrical, usually with longitudinal keels, with few scattered hairs but no dense cushions of micropilosity; metasoma past petiole distinctly elongate, anterior margin of syntergite very narrow, subequal in width to petiole, margin somewhat elevated and flexed upward, with moderate to deep median notch and sometimes with additional crenulae or short striae at sides, rarely anterior margin not notched, tergites past syntergite usually very narrow, forming broad short triangle, tergites sometimes telescoped under syntergite. 
ReCOGNITION AND ReLATIONSHIPS: Entomacis is a very large genus, especially in the Neotropical region with large numbers of undescribed species. Entomacis is related to Doddius and Poecilopsilus; from Doddius it differs principally by the nonstriate cheeks and the ratio of marginal and stigmal veins, from Poecilopsilus by the structure of the notauli and the absence of a long median process on the dorsellum. Entomacis is represented by numerous undescribed species in the Valdivian forest of Chile (also in New Zealand and temperate Australia); these are considered the most primitive stock of the genus as exemplified by relatively complete venation of the forewing, more widely separated toruli, and the presence of epicnemial pit, epicnemial carina and the crenulae along the posterior margin of the mesopleuron. These species are also remarkable for dense micropilosity of the body.

DisTRIBUTION: Entomacis is nearly worldwide in its distribution; in the New World we examined specimens from Ellesmere Island in the high Arctic of Canada to Patagonia of Chile, with individuals occurring from lowland rainforest to the highest elevations in the Andes (paramo).

BIOLOGY: One species was reared from terrestrial Ceratopogonidae; it is highly probable that the entire genus is associated with Ceratopogonidae, as exemplified by the occurrence of its members in wet, moist, semiaquatic habitats.

Epomium, new genus Figure 53

Diagnosis ( $q \hat{o})$ : Medium to large-sized $(3.5-4 \mathrm{~mm})$ robust individuals; body color predominantly black with appendages lighter; head and mesosoma partly to predominantly roughly sculptured, head rugose-punctate, mesosoma with longitudinal keels and carinae and irregular rugose sculpture, shining, with abundant dense pilosity, no hairy cushions or foamy structures; clypeus slightly elongate, relatively narrow, with anterior margin projecting and flexed; apex of A1 deeply emarginate ventrally, with apical flaps well developed; epomium strongly developed, angular and pointed; scutellar pit bifoveate; forewing with costal cell very broad; upper part of basal vein strongly arcuate, bent backward; hind wing with closed basal cell, basal and median veins tracheate, but without pigment, almost transparent; anterior margin of syntergite with deep long median cleft.

DESCRIPTION ( $q$ $\widehat{o}$ ): HEAD. Head in dorsal view slightly transverse, subrectangular, with shelf and toruli projecting; toruli connected with carina, carina sometimes with slight median declivity; temples subequal to or shorter than length of eye; head in lateral view with antennal shelf partly developed; level of torulus at midpoint of eye; eye subcircular, with long pilosity; oral carina not developed; postgenal cushion not developed; occipital flange moderate; head in frontal view with face relatively long; clypeus strongly convex, subtriangular; epistomal depression distinctly developed; anterior margin of clypeus strongly projecting and distinctly flexed; labrum not exposed; malar sulcus strongly developed; lower gena usually with fan of strong striae, striae rudimentary to absent in some species; tentorial pit minute or absent; mandible short, strong, bidentate, with lower tooth longer; palpi long and slender, palpal formula 5-2; head in ventral view with hypostomal bridge not developed; antennal formula 13-13; A1 long, typically widest at base and gradually tapering, apical rim deeply excavate ventrally, produced into two distinct flaps; A2 in both sexes in dorsal view strongly compressed basally, wedge-shaped, fitting between flaps of A1; female clava nonabrupt, multisegmented (6-7 segments); clavomeres progressively thickened, only moderately flattened ventrally; A13 largest, slightly longer than A12, with no pit ventrally; male antenna filiform, with short scattered pilosity; A3 shorter than A1, longer than or subequal to A4; A4 only slightly emarginate, with longitudinal carina. MESOSOMA. Mesosoma short, robust, wider than high, remarkably flattened dorsally; prothorax in dorsal view with distinct cervix and sharply angular pronotal shoulders; side of pronotum considerably concave medially, mostly smooth and glabrous, with sharply carinate epomium, with dense pilosity in front of epomium; posterior margin of pronotum (between forecoxa and spiracle) noncrenulate, at most with one shallow pit; pro- 
pleuron almost smooth, with short scattered appressed pilosity; mesoscutum almost semicircular, predominantly with coarse longitudinal rugulosity or longitudinal keels, with scattered semierect long hairs; parapsidal and anterior parallel lines replaced by strong keels; notaulus percurrent, deeply compressed, noncrenulate; humeral and suprahumeral sulci developed, sometimes obscured by rugosity; anterior scutellar pit bifoveate, pits large, irregular, often obscured by rugosity; scutellar disc subquadrate, with lateral keels relatively well developed; axillar and lateral pits present but often obscured by rugosity; posterior scutellar pits always well developed; posterior margin of axilla sharp; axillar depression deep, filled with fine pilosity; mesopleuron almost flat, predominantly glabrous and smooth; median oblique depression not well defined; epicnemial pit deep, with abundant pilosity; sternaulus strongly developed, broad, noncrenulate; posterior margin of mesopleuron with several large irregular pits; metanotum relatively well developed; dorsellum distinctly elevated, with three short longitudinal keels and abundant pilosity; metapleuron rough rugulose, entirely hairy; propodeum moderately long, median keel moderately raised anteriorly; posterior margin of propodeum excavate medially, with four blunt corners (upper and lower ones) laterally; median part of propodeum less hairy, with more abundant pilosity at sides; plica often obscured by irregular keels on propodeum; nucha short, not distinctly exposed; forewing relatively short and narrow, rounded apically, with short marginal cilia; foremargin of forewing with series of long semierect bristles on costal vein; wing venation of forewing reaching middle of wing length; costa either tracheate or hyaline, submarginal vein strongly tracheate, costal cell moderately wide, marginal vein strongly pigmented, moderately elongate, rarely as long as wide, short stigmal vein slanted toward marginal vein, postmarginal vein rudimentary; basal vein tracheate, upper part of basal vein strongly arcuate, bent backward in acute angle with submarginal vein; posterior part of $M$ vein partly tracheate; basal part of Rs, apex of $M$ and often $\mathrm{Cu}$ nebulous; hind wing with tracheate submarginal vein and basal cell closed by tracheate veins, veins glassy without pigment; wings often shortened, not exceeding base of syntergite; legs moderately long, trochanters strongly elongate, anterior constricted part of femora relatively short. METASOMA. Metasoma long pedunculate; petiole distinctly elongate, cylindrical to subcylindrical, at least twice as long as wide, typically with longitudinal irregular carinae or with irregular rugulosity, generally glabrous dorsally, hairy ventrally, with moderate to distinct anterior flap; metasoma past petiole ovoid, moderately wider than high, only slightly convex dorsally; anterior margin of syntergite with deep cleft medially; apex of metasoma in female only shortly pointed, hypopygium broadly triangular, not distinctly compressed; anterior margin of S2 with moderate to strong rim.

TyPE SPECIES: Epomium cicatrix, new species (described below), by present designation.

RECOGNITION AND RELATIONSHIPS: Epomium is compared best with Ferrugenus, sharing with it several symplesiomorphic character states such as the basal cell in the hind wing enclosed by tracheate veins, tracheate basal vein in forewing, broad costal cell, etc. The two genera also share the strongly angular epomium and the deeply cleft anterior margin of the syntergite. Epomium differs from Ferrugenus by the structure of the clypeus, presence of malar sulcus, the structure of the apex of the A1, the remarkably flattened mesonotum, and by the striate gena in most species.

ETYMOLOGY: The name refers to the strong development of the epomium on the side of the pronotum; the gender is neuter.

DISTRIBUTION: Several species are known to us from the Valdivian forest in Chile. We also examined a member of Epomium from South Africa (relict forest in Drakensberg) suggesting possible Gondwanic origin of the genus.

BIOLOGY: Unknown.

Epomium cicatrix, new species Figure 53

DESCRIPTION: Holotype, $q$ : Length 3.7 $\mathrm{mm}$; head, mesosoma except tegula, petiole, A1 except for apex and coxae black, tegula, 
palpi, apex of A1, A2-A7 reddish brown, legs dark brown, tarsi light brown, A8-A13 brown, metasoma past petiole dark brown; small brownish spot below stigmal vein in forewing. HEAD. Head in dorsal view slightly wider than long (72:64); occiput and temple with deep rough rugose punctures; temple distinctly shorter than eye (12:27), strongly receding; toruli separated by space subequal to their diameter; head in lateral view slightly higher than long (71:64), eye slightly higher than long (33:25); eye height larger than malar space $(33: 28)$; head in frontal view with space between toruli only slightly emarginate, with shallow declivity below; face smooth, with numerous setigerous punctures; tentorial pits small but distinct; striae on gena not exceeding half distance toward lower orbit; A1 predominantly smooth, with setigerous punctures, distinctly widest basally; antennal segments in relative proportions (57:13.5), (15:12), (27:9), (13: 9.5), (12:10), (11:10), (10:11), (10:12), (10: 12.5), (10:12.5), (10:12.5), (11:12.5), (17: 13). MESOSOMA. Mesosoma longer than wide (125:80); pronotum dorsally rough rugose-punctate, with dense pilosity; side of pronotum considerably concave, smooth and mirrorlike-shining, with two rows of short hairs, one near posterior margin, another in middle; dorsal margin of pronotum (adjacent to mesoscutum) with three large irregular pits, margin of epomium very sharp, almost flexed; mesoscutum with anterior parallel lines replaced by strong keels, parapsidal lines also replaced by keels; median lobe of mesoscutum with percurrent central longitudinal keel and irregular shallow punctures posteromedially; humeral and suprahumeral sulci with some crenulae; anterior scutellar pits divided by low septum; axilla with two or three irregular large punctures; scutellar disc with several irregular longitudinal keels; posterior scutellar pits developed (4-5); mesopleuron predominantly glabrous, with deep longitudinal sulcus dorsally (below tegula); sternaulus broad, borded anteriorly by deep, hairy epicnemial pit; posterior margin of mesopleuron with three large irregular pits; propodeum in dorsal view with three large polygonal fields on each side of median keel; forewing only slightly exceeding tip of metasoma; marginal vein in forewing distinctly elongate (16:7); postmarginal vein rudimentary; stigmal vein distinctly shorter than marginal vein. METASOMA. Petiole pencil-like, distinctly longer than wide $(46: 20)$, with irregular longitudinal keels dorsally, otherwise smooth and shining, predominantly glabrous dorsally, with long semierect hairs laterally; syntergite longer than rest of metasoma (100: 62 ), smooth and shining, with only very few scattered hairs.

MALE: Unknown.

TYPe MATERIAL: $17 q$. Holotype, $q$ (CNCI no. 22454), CHILE, Malleco Prov., 12 km E Malalcahuello, $1350 \mathrm{~m}$, trap site 650, December 13-31, 1982, A. Ne wton and M. Thayer, Nothofagus dombeyi-Araucaria forest; well preserved. Paratypes, $12 \%$, same data as holotype; 29 , Concepcion, Boca BioBio, May 24, 1957, no collector; 19 , Nuble Prov. Trancas, 1700 m, December 6, 1984February 4, 1985, S. \& J. Peck, FIT; 19 , Malcho Prov., Parral-Talca, January 12-26, 1993, L.E. Peña, mixed forest. All type material in CNCI.

ETYMOLOGY: From cicatrix (Latin), meaning scarred, in reference to the rough sculpture on the head and mesosoma.

Distribution: Chile (Valdivian forest).

BiOLOGY: Unknown.

VARIATION: No substantial variation encountered in the type series.

\section{Ferrugenus, new genus}

Figures 54, 55b, 56

Diagnosis $(q \diamond)$ ): Medium to large-sized $(3.6 \mathrm{~mm})$ robust individuals; body color predominantly reddish brown to ferrugineous, with appendages lighter; head, most of mesosoma and petiole predominantly rough rugose, shining, with abundant dense pilosity, no hairy cushions, and no foamy structures; apex of A1 not emarginate ventrally; A2 subquadrate, with sharply constricted base, A3 in female remarkably elongate; epomium strongly developed, angular and pointed; notaulus deeply crenulated; scutellar pit bifoveate; axillar keels strongly developed, sharp; forewing with costal cell broad; marginal vein strongly developed, thick; postmarginal vein present; hind wing with closed basal cell, basal and median vein tracheate but without pigment, almost transparent, poste- 
rior part of $\mathrm{M}$ rudimentary; anterior margin of syntergite with deep long median cleft.

DESCRIPTION ( $q$ o $)$ : HEAD. Head in dorsal view transverse, subrectangular, with shelf and toruli strongly projecting; temple relatively short, receding; toruli partly separated, with shallow emargination in between; head in lateral view with antennal shelf partly developed; level of torulus distinctly at lower arc of eye; eye subcircular, with long pilosity; oral carina absent; postgenal cushion not developed; occipital flange broad, with rough crenulae; head in frontal view with face relatively broad and short; mandible short but strong, bidentate, lower tooth slightly longer; clypeus moderately convex, distinctly wider than long, anterior margin of clypeus not distinctly flexed; epistomal depression shallow; labrum not exposed; tentorial pit present; malar sulcus not developed; head in ventral view with hypostomal bridge not developed; palpal formula 5-2; antenna formula 13-13; A1 long and slender, slightly wider basally, tapering apically, apical rim not excavate ventrally, rim not produced into flaps; A2 in both sexes characteristically constricted basally, subquadrate; A3 in female remarkably elongate, female clava almost indistinct, 78-segmented, clavomeres only moderately flattened ventrally, A13 slightly longer than A12, with no ventral pit; male antenna almost filiform, with short scattered pilosity, A3 shorter than A1 but longer than A4, A4 with moderate constriction basally and longitudinal carina in basal half. MESOSOMA. Mesosoma short, robust, wider than high, only moderately convex dorsally; prothorax in dorsal view with short cervix and sharp angular pronotal shoulders; side of pronotum deeply concave, partly smooth and glabrous, with sharp angular-pointed epomium and dense pilosity in front of epomium; posterior margin of pronotum (between forecoxa and spiracle) noncrenulate or pits; propleuron almost entirely concealed under head, hairy; mesoscutum almost semicircular, distinctly wider than long, with rough rugulosity and long scattered semierect hairs; parapsidal and anterior parallel lines replaced by keels; notaulus percurrent, very broad, dilated and converging posteriorly, deeply crenulate; humeral and suprahumeral sulci obscured by rough rugosity; anterior scutellar pit bifov- eate, pits large and irregular; scutellar disc subquadrate without lateral keels; lateral, axillar, and posterior scutellar pits replaced by rugosity; posterior margin of axilla rounded; axillar depression with irregular borders, with abundant pilosity; mesopleuron slightly concave, median oblique depression not well defined; epicnemial pit deep, with abundant pilosity; sternaulus replaced by rugosity; posterior margin of mesopleuron with row of large irregular pits or crenulae; metanotum strongly developed, medially as long as half of scutellum, almost as long as propodeum; dorsellum weakly defined, moderately bulging, with three indistinct longitudinal keels; metapleuron rough rugulose, partly glabrous; propodeum relatively short, median keel moderately raised anteriorly, posterior margin of propodeum deeply excavate, with four strong blunt corners (upper and lower ones), median part of propodeum almost glabrous, sides of propodeum hairy; nucha short, almost smooth, not concealed under anterior margin of petiole; forewing broad, rounded apically, with minute marginal cilia; costa and submarginal vein tracheate, enclosing broad costal cell; marginal vein strongly developed, thick, moderately elongate, stigmal vein subperpendicular and shorter than marginal vein; postmarginal vein shortly developed; basal vein tracheate, nonarcuate, distinctly joining submarginal vein at acute angle; posterior part of $\mathrm{M}$ vein (past base of basal vein) tracheate; basal part of Rs distinctly nebulous, apical part of Rs nebulous; hind wing with tracheate submarginal vein and tracheate enclosed basal cell; legs strong and short, apices of femora without distinct flaps. METASOMA. Metasoma short, pedunculate; petiole only moderately elongate, without anterior flap, with irregular rugosity, predominantly glabrous dorsally, with dense long hairs ventrally and at sides; metasoma past petiole ovoid, moderately wider than high, moderately flattened dorsally; anterior margin of syntergite with remarkably long, deep median cleft; apex of metasoma in female almost blunt, apical sternite short, not compressed; anterior margin of S2 flexed, rimlike.

TyPe SPECIES: Ferrugenus chilensis, new species (described below), by present designation. 
ReCOGNITION AND ReLATIONShips: Ferrugenus and Epomium share several highly plesiomorphic character states such as tracheate basal and posterior median veins, broad costal cell and thick marginal vein in forewing and fully tracheate closed basal cell in hind wing. On the other hand, the deeply crenulate notaulus, the rough rugose sculpture of the head and mesosoma as well as the deep cleft on anterior margin of the syntergite in Ferrugenus is considered highly apomorphic. Ferrugenus differs from Pentapria by the bifoveate anterior scutellar pit, furthermore by the sharply pointed epomium, elongate A3 in female antenna and moderately developed median keel of propodeum. Ferrugenus shares similar structure of the scapal (A1) rim with Entomacis and Poecilopsilus; it differs from both in wing venation and structure of the antenna.

ETYMOLOGY: The Latin name implies the prevailing color of the body, which is reddish brown to ferrugineous; the gender is masculine.

DisTRIBUTION: At present, only one species is known from the Valdivian forest of Chile. BIOLOGY: Unknown.

\section{Ferrugenus chilensis, new species}

Figures 54, 55b, 56

DESCRIPTION: Holotype, $q$ : Length 3.6 $\mathrm{mm}$; head, mesosoma and petiole dark reddish brown, antenna ferrugineous; tegula, legs including coxae, most of mandible and palpi yellowish brown; metasoma past petiole predominantly chestnut-brown; wings almost clear; forewing with veins, especially marginal vein, deeply pigmented. HEAD: Head in dorsal view slightly wider than long (92:75); upper frons, vertex and occiput with rough rugose sculpture forming irregular polygons with deep pits; temple behind eye shorter than eye length; space between inner rims of toruli subequal to diameter of torulus, shorter than distance between outer rim of torulus and inner orbit of eye; head in lateral view slightly higher than long (85:75), eye slightly higher than long (40:32); eye height larger than malar space (40:30); head in frontal view with toruli divided by shallow declivity; clypeus smooth and shining, without rugosity; A1 predominantly smooth ventral- ly, with scattered punctures, finely rugulose dorsally, in lateral view broadest at base, with sharp basal margin (right above radicle) gradually tapering toward apex; antennal segments in relative proportions (67:16), (14: 12), (40:12), (12:13), (12:14), (12:14.5), (12: 15), (12:15), (12:15), (12:15), (12:15), (12: 15), (23:15). MESOSOMA. Mesosoma longer than wide (158:110); notaulus with large crenulae, notaulus dilated posteriorly, space between inner margins of notauli subequal to width of notaulus posteriorly; anterior scutellar pits large, irregular, divided by narrow septum; tegula and axillar keel smooth; upper anterior corner of mesopleuron (below tegula) with patch of dense pilosity followed below by zone of coarse areolate rugae, sternaulus replaced by zone of areolate rugae; dorsellum relatively broad, only slightly shorter than propodeum (22:27); forewing venation (tip of postmarginal vein) distinctly exceeding half of wing length; marginal cilia very short in ratio to maximum wing width (5:110); apex of stigmal vein with short tracheate knob (part of Rs). METASOMA. Petiole only slightly elongate (15:10); metasoma past petiole moderately elongate (123:90), incision on anterior margin of syntergite extending to basal sixth of syntergite, syntergite perfectly smooth and almost glabrous, with few erect hairs anterolaterally; following tergites smooth; T7 with distinct pilosity laterally; spiracle on T8 large; cercus on T9 small; apical sternite short, subtriangular with dense pilosity; S2 with two longitudinal rows of long scattered semierect hairs.

MALE: Very similar to female, differing only in structure of A3-A13; antennal segments in relative proportions (58:13), (13: 11), (36:10), (25:10.5), (18:11), (16:11), (17: 11.5), (17:12), (17:12), (17:12), (17:12), (17: 12), (25:11); A3-A12 with dense semidecumbent pilosity not exceeding one-fifth of length of antennomeres; cercus of T9 distinctly more developed than in female.

Type Material: $5 q 0$. Holotype, $q$ (CNCI no. 22455), CHILE, Nuble Prov., Las Trancas, $19.5 \mathrm{~km}$ ESE Recinto, $1250 \mathrm{~m}$, December 10, 1983, A. Newton and M. Thayer; left forewing glued on point. Allotype: $\hat{\delta}$, same data as holotype. Paratypes, 10 , CHILE, Nuble Prov., 22 km ESE Recinto, $1330 \mathrm{~m}$, December 1983-January 
1984, A. Newton and M. Thayer, Nothofagus forest; $1 \hat{\delta}$, Malleco Prov, Princesa, $20 \mathrm{~km}$ Curacautin, $1000 \mathrm{~m}$, December 12, 1984February 16, 1985, S. \& J. Peck, FIT, Nothofagus forest; 1 , Cautin Prov. $21 \mathrm{~km} \mathrm{NE}$ Pucon, Lago Caburga, 600 m, December 15, 1984-February 10, 1985, S. \& J. Peck, FIT, mixed forest remnant. All paratypes deposited in CNCI.

ETYMOLOGY: The species name refers to the country of origin.

DisTRIBUTION: Chile (Valdivian forest).

BIOLOGY: Unknown.

VARIATION: No variation encountered in type material.

\section{Idiotypa Foerster}

Figures 59, 60

Idiotypa Foerster, 1856: 122, 125.

Diagnosis $(q \hat{o})$ : Small to medium-sized $(1-3.5 \mathrm{~mm})$ robust individuals; body color often pale, reddish orange to yellow, less frequently brown to dark brown, smooth, with abundant pilosity, hairy cushions at most weakly developed on postgena and anteriorly on pronotum, foamy structures not developed; antennal shelf not developed; toruli separated by gap, rarely contiguous but not connected by carina; antennal formula 12 13; anterior scutellar pit usually tripartite; forewing with venation distinctly exceeding basal half of wing length, stigmal vein almost perpendicular to marginal vein; postmarginal vein relatively long; Rs 2 nebulous, down-curved; anterior margin of syntergite rimlike flexed, with short longitudinal keels, folds or striae, always deeply notched medially.

DESCRIPTION ( $q$ o ): HEAD. Head in dorsal view slightly transverse, subquadrate or subrectangular, with toruli moderately projecting; toruli separated by gap, rarely contiguous but not connected by carina; temple relatively short, receding; head in lateral view with antennal shelf weakly developed; level of torulus in lower half of eye; eye subcircular to ovoid, with long pilosity; oral carina not developed; temple behind posterior orbit very rarely crenulate; postgenal cushion weakly developed or absent, but area often with dense pilosity; occipital flange narrow but well developed, rarely crenulate; head in frontal view with face broad; mandible short and strong, bidentate, rarely right mandible subtridentate; clypeus small, with weak epistomal depression; labrum not exposed; tentorial pits well developed; malar sulcus present or absent; head in ventral view with hypostomal bridge not developed; palpal formula 5-2; antennal formula 12-13; A1 relatively long in female, shorter in male, with apical rim unarmed and only moderately emarginated ventrally; female antenna predominantly with robust nonabrupt multisegmented clava, A12 only moderately longer than preceding clavomeres, all clavomeres distinctly flattened ventrally; male antenna filiform, with scattered short hairs, A2 remarkably short, subquadrate, A3 and A4 subequal, A4 modified, with long ventral carina. MESOSOMA. Mesosoma generally short and stout, slightly wider than high, only moderately convex dorsally; prothorax in dorsal view with distinct cervix; pronotal shoulders moderately to strongly projecting, rounded, rarely sharp; side of pronotum in upper anterior corner often with hairy cushion or dense pilosity or with deep subcircular depression; epomium usually not developed, sometimes its horizontal part developed, in few species complete and very sharp; posterior margin of pronotum (between forecoxa and spiracle) noncrenulate or ridges; propleuron generally hairy; mesoscutum slightly wider than long, only moderately convex, parapsidal and admedian lines not developed; notaulus complete, noncrenulate; humeral and suprahumeral sulci deep, often crenulate, sometimes crenulae continuing along anterior margin of midlobe; anterior scutellar pit typically tripartite, with median pit largest, flanked by two smaller pits or pit replaced by arc of smaller pits, or median pit strongly expanded and lateral pits rudimentary; scutellar disc subquadrate, or transversely subrectangular, flat or moderately convex, lateral keels sharp or rounded; posterior scutellar pits well developed; posterior margin of axilla distinctly rounded; axillar depression deep, often with fine pilosity; mesopleuron moderately convex, with shallow oblique median depression; epicnemial pit large, deep, usually bordered posteriorly by crenulate epicnemial carina; sternaulus absent; posterior margin of mesopleuron rarely with 
row of crenulae or pits, sometimes only few pits right above mesocoxa; metanotum moderately developed; dorsellum broad, considerably raised with three prominent keels; metapleuron generally rugose and hairy; propodeum in dorsal view relatively short, with areas between plica and median keel often smooth and glabrous, median keel strongly developed, pointed to finger-shaped, point usually bent backward; plica well developed, usually angular; side of propodeum hairy; forewing relatively short, rounded apically, with relatively long marginal cilia, long erect bristles on costa, with venation distinctly exceeding basal half of wing length; costa and submarginal veins tracheate, enclosing relatively narrow costal cell, marginal vein slightly to distinctly elongate, with stigmal vein shorter, subperpendicular to marginal vein, postmarginal vein moderately to distinctly developed, but subequal to or shorter than marginal vein; basal vein nebulous but deeply pigmented, nonarcuate, joining submarginal vein at slanted angle; Rs2 (below apex of stigmal vein) nebulous, characteristically down-curved; posterior part of $\mathrm{M}$ and $\mathrm{Cu}$ veins sometimes weakly pigmented; hind wing with complete sclerotized submarginal vein; wings reduced in several species to narrow strips not exceeding propodeum, with mesosoma generally reduced, and ocelli absent; legs relatively short. METASOMA. Metasoma relatively short and broad, wider than high; petiole at most only slightly wider than high, subcylindrical, with longitudinal keels, petiole almost glabrous dorsally, moderately to strongly hairy ventrally; anterior margin of syntergite rimlike flexed, with short longitudinal keels, folds or striae, always deeply notched medially; apex of metasoma in female blunt, apical sternite broad, not compressed, usually densely hairy; base of S2 with elevated anterior margin flanked by two short hairy grooves.

RECOGNITION AND ReLATIONSHIPS: Among the Spilomicrini, Idiotypa comes closest to Pentapria Kieffer, from which it differs by the wing venation (nonarcuate basal vein, strong development of postmarginal vein) and strong development of the median propodeal keel. Typically, individuals of Idioty$p a$ are more lightly colored than blackish individuals of Pentapria. We tentatively clas- sify in Idiotypa a large complex of shortwinged or apterous, highly modified species $\left(\begin{array}{ll}o & \delta\end{array}\right)$ from the Valdivian forest in Chile and Argentina. Female antenna usually 13 -segmented (rarely 10,11 , or 12 ), male antenna always 14-segmented, with A4 modified. Final classification of this complex would require data on wing venation.

DISTRIBUTION: This worldwide genus is well represented in the New World by a high number of species especially in the Neotropics.

BIOLOGY: Idiotypa nigriceps Kieffer was reared from puparia of Phoridae (Diptera) (specimens in Zoological Museum Copenhagen, D. Notton, personal commun.). Considerable variation on body length exists among individuals from long series of a Japanese species (CNCI).

\section{Paramesius Westwood Figures 80, 81}

Paramesius Westwood, 1832: 129.

Aparamesius Kieffer, 1913: 436. Synonymized by Masner in Krombein and Burks, 1967.

DiAgnosis $(q \diamond)$ ): Small to large-sized individuals $(1.5-5 \mathrm{~mm})$; body color predominantly dark, black or brownish black, rarely light brown to orange, smooth and highly shining; body predominantly glabrous without micropilosity, usually with sparse semierect to erect long hairs; hairy cushions often present on postgena, side of pronotum, upper part of propleuron, in front of mid and hind coxae and ventrally on petiole, foamy structures rarely present in company of hairy cushions; antennal shelf either with toruli interconnected with sharp carina or, with toruli more or less wide apart; A13 in female distinctly longest and largest of all clavomeres, A3 in male distinctly shorter than A4; marginal vein in forewing distinctly elongate, at least twice as long as short stigmal vein; anterior margin of syntergite tightly fitting over posterior apex of petiole; apex of female metasoma sharply conical with long compressed apical sternite.

DESCRIPTION ( $q$ o): HEAD. Head in dorsal view subpentagonal with toruli strongly projecting; toruli either connected by sharp carina or separated by slight emargination to completely separated, not connected by ca- 
rina; temples relatively short, strongly receding; head in lateral view with antennal shelf relatively well developed; level of torulus usually around middle of eye; eye subcircular to ovoid, with relatively large ommatidia; oral carina either developed or absent; postgenal cushion usually developed; occipital flange relatively broad, sharply defined, usually noncrenulate; head in frontal view with face relatively long; mandible short but strong, bidentate, with lower tooth usually longer; clypeus moderately convex, anterior margin of clypeus straight; epistomal sulcus often indicated by declivity; labrum moderately to strongly exposed; tentorial pits minute to well developed; malar sulcus not developed; head in ventral view with hypostomal bridge not developed; palpi long and slender, palpal formula 5-2; antenna in both sexes 13-segmented; A1 remarkably long and slender, with apical rim unarmed and only moderately emarginated ventrally; female antenna with moderate, nonabrupt, gradually incrassate, multisegmented clava, clavomeres not flattened ventrally, A13 always longest and largest, without ventral pit; male antenna filiform, with scattered short hairs, A3 usually diminished, subequal in length or equal to $\mathrm{A} 2$, always distinctly shorter than A4; A4 (rarely A3 and A4) modified, with sharp longitudinal carina, very rarely A4 not modified, without carina. MESOSOMA. Mesosoma generally short, usually as high as wide, slightly to distinctly convex dorsally; prothorax in dorsal view with cervix strongly developed; pronotal shoulders usually well developed and rounded, sometimes sharp, rarely shoulders not developed; side of pronotum anteriorly with scattered pilosity, rarely pilosity denser, forming a cushion; epomium often well developed, at least its horizontal part, in dorsal part forming sharp edge of pronotal shoulder; posterior margin of pronotal side (between forecoxa and spiracle) usually with row of crenulae or transverse ridges; propleuron generally hairy, sometimes with hairy cushions or foamy structures; mesoscutum moderately elongate, subtriangular, moderately to strongly convex; anterior parallel and parapsidal lines weakly developed or absent; notaulus complete, abbreviate or absent, usually better impressed posteriorly; humeral sulcus always present, rarely crenulate, suprahumeral sulcus sometimes developed; anterior scutellar pit usually large, deep, transversely oval, often with longitudinal keels on bottom, rarely with median septum wider and hence bifoveate, very rarely pit shallow to absent; scutellar disc subrectangular or subquadrate, in some species highly elevated, with sharp lateral keels and deep lateral scutellar pits; posterior scutellar pits present, indistinct, or absent; posterior margin of axilla relatively sharp; axillar depression large, deep, usually continuing under posterior margin of axilla, sometimes with small foamy structures on bottom; mesopleuron moderately convex, oblique median depression very shallow or absent; epicnemial pit usually well developed; sternaulus developed or replaced by row of rugose punctures or multiple horizontal ridges, or sternaulus absent; posterior margin of mesopleuron noncrenulate or pits; metanotum moderately developed; dorsellum not prominent, usually with three minute keels; metapleuron deeply concave anteriorly, usually coarsely rugose and densely hairy; propodeum moderately elongate, with median part (between plicae) often glabrous and smooth, median keel moderately to strongly developed, elevated and pointed anteriorly; plica moderately to strongly developed; posterior margin of propodeum moderately to strongly rimlike, with posterolateral corners usually moderately projecting; side of propodeum rugose and densely hairy; forewing usually long and slender, perfectly rounded apically, marginal cilia fairly long, venation reaching to middle of wing length; costa tracheate; costal cell relatively narrow, marginal vein distinctly elongate, at least twice as long as short stigmal vein; postmarginal vein at most rudimentary; basal vein nebulous in acute angle toward submarginal vein but never joining it, or basal vein vague or absent, other veins usually not indicated; hind wing with complete submarginal vein; wings very rarely shortened; legs distinctly elongate and slender, including coxae, hind coxa in particular, claws relatively strong. METASOMA. Metasoma long-pedunculate; petiole distinctly elongate, usually several times longer than wide, pencil-like, slightly to distinctly expanded anteriorly (over nucha), typically 
with longitudinal carinae, very rarely perfectly smooth, typically glabrous dorsally, always densely hairy or with foamy structures ventrally; metasoma past petiole elongate, sharply conical-pointed apically in females, ovoid in males; anterior margin of syntergite tightly articulating with posterior margin of petiole, sometimes with short deep incision or cleft anteromedially, or with two very shallow depressions anterolaterally; female apical sternite long, plow-shaped, strongly compressed; base of S2 without keels.

RECOGNITION AND RELATIONSHIPS: Paramesius can be compared with Entomacis and Spilomicrus; from the former it differs principally by the wing venation of the forewing (ratio of marginal and stigmal veins), from the latter by the structure of female apical sternite, the structure of male antenna (ratio of A3 and A4), by the enlarged A13 in females, and by articulation between petiole and rest of metasoma.

DistRIBUTION: In the New World numerous species occur from Canada to Chile; this large genus is almost worldwide in distribution.

Biology: The hosts are not known, but presumed to be Diptera.

\section{Pentapria Kieffer \\ Figures 85, 86}

Pentapria Kieffer, 1905a.: 34.

Antipapria Fabritius, 1968: 844. NEW SYNONYMY. Bakeria Kieffer, 1905a: 34. NEW SYNONYMY.

Plutopria Kieffer, 1910b: 48. NEW SYNONYMY.

Spilomicrinus Ogloblin, 1957: 425. NEW SYNONYMY.

Xenopria Fouts, 1939: 260. Synonymized by Masner, 1964a: 134.

Diagnosis ( $q$ $\widehat{0})$ : Medium to large-sized individuals (1.5 to $6 \mathrm{~mm}$ ); body predominantly ebony black, rarely light brown with appendices often light colored, body smooth and shining, head and mesosoma usually with deep scattered punctures, sometimes with rough sculpture, body with scattered semidecumbent hairs, hairy cushions and foamy structures not developed; head in lateral view with antennal shelf remarkably protruding; torulus distinctly at level of lower orbit of eye (lateral view); face relatively short, subequal in length to clypeus; mandible in lateral view distinctly prominent, sep- arate from lower margin of clypeus by deep cleft, space filled by exposed sclerotized labrum; mesosoma generally wider than high, sometimes moderately to strongly depressed dorsoventrally; propleuron usually distinctly convex; anterior scutellar pit generally tripartite; propodeum generally depressed, sometimes completely flat; forewing with costal cell remarkably broad; stigmal vein usually short, oblique to almost horizontal; anterior margin of syntergite always modified, concave, generally with median excision flanked by lateral depressions.

DESCRIPTION ( $q$ †): HEAD. Head in dorsal view usually subquadrate, often wider than high, rarely strongly depressed, elongate or globular; frons unarmed, antennal shelf moderately to strongly developed, temple behind eye often parallel, rarely rounded, receding or diverging posteriorly; head in lateral view with antennal shelf remarkably protruding but never sharply pointed, torulus distinctly in level of lower orbit of eye; eye subcircular with scattered hairs, ocelli relatively small, reduced or absent in short-winged or apterous species, sometimes lateral ocelli with semicircular groove posteriorly; oral carina absent or short-pointed; occipital flange usually moderate, sometimes strongly developed and crenulate; face relatively short, subequal in length to clypeus, often with transverse sculpture or ledge; mandible strong, bidentate, always distinctly prominent, clasped or crossing, never falcate, rarely strongly elongate, sicklelike crossing and unidentate or rounded apically; clypeus moderately convex, subtriangular, in lateral view separated from upper margin of mandible by deep cleft, epistomal sulcus often weakly developed; labrum exposed, sclerotized, semicircular or subtriangular, often distinctly serrate on anterior margin; tentorial pit present or absent; malar sulcus often well developed; hypostomal bridge not developed; palpi long, formula 5-2; female antenna 13-segmented, relatively short, generally clavate, clava usually nonabrupt, clavomeres distinctly separate, usually transverse or beadlike, A1 cylindrical, without keels, unarmed apically; male antenna 13-segmented, threadlike, A4 sexually modified, A3-A13 with scattered dense nonverticillate pilosity. MESOSOMA. Mesosoma generally wider than high, some- 
times moderately to strongly depressed dorsoventrally, in lateral view slightly to strongly flattened dorsally, mesosoma moderately to strongly modified in short-winged and wingless species, with sutures, sulci, and pits gradually obliterated; pronotum in dorsal view moderately to strongly developed, often subangular anterolaterally, cervix often strongly developed, pronotum often deeply punctured, side of pronotum usually with deep, horizontal sulcus medially, epomium rarely developed; propleuron usually distinctly convex; mesoscutum broad, notaulus generally complete, anterior parallel lines rarely developed, parapsidal lines absent, humeral and suprahumeral sulci usually developed; anterior scutellar pit generally tripartite, sometimes pits rugulose, not clearly defined, or scutellum with series of small pits arranged in arc anteriorly, scutellar disc moderately to strongly flattened, lateral keels usually not developed, posterolateral and posterior scutellar pits usually well developed; posterior margin of axilla usually rounded, axillar depression usually moderate or absent, glabrous or with sparse pilosity; mesopleuron slightly to distinctly wider than high, moderately convex, epicnemial pit present, often rugulose, sometimes with chain of crenulae continuing upward; sternaulus usually present, sometimes superimposed by horizontal sulcus dorsally; dorsellum rarely defined; metapleuron always strongly sculptured, with scattered pilosity; propodeum generally depressed, sometimes completely flat, rugulose to almost smooth, median keel weakly developed or absent, keel very rarely pointed upwards, plica usually not developed, spiracle located near upper margin of propodeum, usually only one diameter away from dorsellum, nucha relatively well developed; forewing relatively short and narrow, with abundant microtrichia, venation distinctly surpassing basal third of wing length, often reaching almost to middle of wing, costa rarely well developed, usually nebulose, depigmented, costal cell remarkably broad, marginal vein usually short, sometimes thickened, rarely not touching anterior margin of wing, postmarginal vein short or rudimentary, stigmal vein usually short, oblique to marginal vein or almost horizontal, basal vein usually well developed, tra- cheate, rarely depigmented, moderately to strongly arcuate, joining submarginal vein long before marginal vein; hind wing with complete tracheate submarginal vein; wings sometimes shortened or absent (both sexes); legs variable, from long and slender to short and stout, femora always distinctly clavate, tarsi sometimes remarkably shortened with strong claws; apex of foretibia with or without spine dorsally. METASOMA. Petiole variable, moderately to strongly elongate, with longitudinal keels, rugulose or punctate, rarely almost smooth or distinctly swollen medially; metasoma past petiole slightly to moderately elongate, at most slightly convex dorsally, strongly depressed or compressed; anterior margin of syntergite always modified, concave, generally with median excision flanked by lateral depressions or anterior margin rimmed, with short longitudinal keels; metasoma with laterotergites 3 plus 4 relatively short, leaving larger part of synsternum exposed; S2 anteriorly often projecting, anterolateral corners of S2 visible in dorsal view, anterior margin of S2 concave, usually with longer median and two shorter lateral grooves often filled with scattered pilosity; apical sternite in female sometimes very large, slightly concave, with scattered specialized pilosity or stiff rufous pegs or sternite with dense brush of long rufous pilosity.

ReCOGNition And Relationships: Pentapria is one of the largest and most polytypic genera of Diapriinae in the Neotropical region. Several marginal species were previously given generic status; however, after examination of the type material of these genera as well as a large amount of additional material, we decided to treat them as junior synonyms (see synonymy above). Pentapria, in this new broader concept is recognized principally on cephalic characters (profile of head with mandibles prominent, exposed labrum, position of toruli), characteristic wing venation (broad costal cell and position of stigmal and postmarginal veins), and the modified anterior margin of the syntergite. Among the Spilomicrini, Pentapria appears closest to Idiotypa, from which it differs conveniently in female by antennal structure; also by structure of mandibles, by exposed labrum, and by different position and length 
of stigmal and postmarginal veins in forewing. The members of Pentapria are usually ebony black (except for some light brown species in Chile); members of Idiotypa are never black, usually brown, reddish brown to almost yellowish.

DisTRIBUTION: The present known distribution of Pentapria is in the New World; three species were described from the Nearctic region (Fouts, 1939) and several from the Neotropical region (Kieffer, 1916). We examined several thousand specimens and estimate a minimum of 150 species to be described from the Neotropic region. The genus is exceptionally diverse in Chile; we also observed an interesting case of sympatric speciation of short-winged and apterous species of Pentapria (=Spilomicrinus) in Juan Fernández Isl. In tropical America, members of Pentapria occur from wet lowlands to high mountains, very abundant in cloud forest zone, reaching to páramo region in high Andes (above $4000 \mathrm{~m}$ ). However, we also examined a single undescribed species from Japan and two undescribed species from Australia (CNCI).

Biology: One species was reared from soldier flies (Stratiomyidae) in North America (Fouts, 1939). It is plausible to assume that Stratiomyidae are the principal hosts of Pentapria, as inferred from the high diversity of soldier flies in the Neotropical region.

\section{Poecilopsilus Ogloblin Figures 87, 88}

Poecilopsilus Ogloblin, 1955: 85-88.

Diagnosis ( $q$ ○): Medium to large-sized individuals (4-6 $\mathrm{mm}$ ); body color mottled light and dark brown; body smooth and highly shining, with abundant pilosity, especially on head and propodeum; foamy structures not developed; antennal shelf not developed, toruli separated by deep gap, not connected by carina; A1 relatively short, subequal to or shorter than A3, apical rim circular, not emarginate ventrally; notaulus complete, deeply incised, strongly crenulate and dilated posteriorly; anterior scutellar pit entire, large; median keel of dorsellum produced into long fingerlike process; forewing generally infuscate, heavily maculate; petiole strongly elongate; anterior margin of syntergite not notched medially, metasoma past petiole in female conical, moderately compressed, female apical sternite long, plow-shaped.

DESCRIPTION ( $q$ đ): HEAD. Head in dorsal view transverse, subrectangular; temples relatively long, moderately receding; toruli separated by deep gap, not connected by carina; head in lateral view with antennal shelf not developed; level of torulus in middle of eye; eye subcircular, highly convex; oral carina not developed; postgenal cushion absent; occipital flange narrow but strongly developed, crenulate; head in frontal view with small pointed crest on frons (between toruli and anterior ocellus), with long face; mandible strong, large, bidentate, with lower tooth distinctly longer; clypeus strongly convex, with middle part subrectangular, with anterior margin almost flexed, with anterolateral corners more or less pointed; epistomal sulcus replaced by deep declivity; labrum not exposed; tentorial pit well developed; malar sulcus strong and broad; cheek and gena not striate; head in ventral view with hypostomal bridge not developed; palpi long and slender, palpal formula 5-2; antenna in both sexes 13-segmented, A1 relatively short, subequal to A3 (female) or distinctly shorter than A3 (male), with apical rim unarmed and not emarginate ventrally, female antenna long and slender, only slightly incrassate toward apex, clava not well defined, 4-5-segmented, clavomeres almost beadlike, not flattened ventrally, A13 only slightly longer than A12; male antenna long, filiform, A3-A13 with dense semierect pilosity, A3 and A4 not bent but with fine, long carinae ventrally. MESOSOMA. Mesosoma generally short, usually as high as wide, highly convex dorsally; prothorax in dorsal view relatively well developed, with cervix distinctly elongate and constricted; pronotal shoulders well developed, but rounded, almost glabrous; epomium not developed; mesoscutum with scapula and mid lobe highly convex; parapsidal and anterior parallel lines moderately developed; notaulus complete, deeply incised, strongly crenulate, distinctly dilated posteriorly; humeral and suprahumeral sulci deep, sharply margined, sometimes with fine crenulae; anterior scutellar pit large, deep, subcircular, entire, slightly smaller than scutellar disc; scutellar disc subrectangular to subquadrate 
with lateral keels moderately developed; lateral scutellar pits reduced or not well developed; posterior scutellar pits minute; posterior margin of axilla rounded; axillar depression large, with sparse pilosity; side of pronotum glabrous, with several deep crenulae in front of spiracle; mesopleuron predominantly glabrous, considerably convex, with only shallow median oblique line, with row of crenulae along posterior margin; epicnemial pit well developed: sternaulus at most weakly developed; metanotum relatively broad; dorsellum with median keel remarkably produced into long fingerlike process; metapleuron with rough rugulosity, densely hairy; entire propodeum densely hairy, propodeum in dorsal view relatively long, subquadrate, median keel and plica not defined, posterolateral corners of propodeum moderately pointed, posterior margin of propodeum not developed, nucha rather short; forewing long and large, subtruncate apically, generally infuscate and remarkably maculate, with rich wing venation, costa hyaline or nonpigmented; submarginal vein tracheate, distinctly remote from foremargin, hence costal cell relatively broad; marginal vein reaching near middle of wing length, elongate, slightly longer than stigmal vein, stigmal vein slightly slanted (not perpendicular) toward marginal vein; postmarginal vein not developed; basal vein only moderately arcuate, deeply pigmented; median vein, Rs and cubitus nebulous; hind wing with submarginal and basal veins tracheate, basal cell open ventrally; legs very long and slender, trochanters distinctly elongate, femora strongly constricted in anterior half, subclavate in posterior half. METASOMA. Petiole remarkably elongate, almost pencil-like, moderately tapering posteriorly, with fine longitudinal rugulosity and scattered pilosity, petiole only slightly shorter (female) or longer (male) than rest of metasoma; anterior margin of syntergite narrow, subequal in width to petiole, not notched medially; apex of female metasoma considerably compressed, conical and long-pointed; base of S2 with two raised converging keels; apical sternite in female long, triangular, plow-shaped.

Recognition and Relationships: Poecilopsilus is closest to Entomacis, Xenismarus and Doddius; it shares with them the struc- ture of the toruli, the shape of the scapal (A1) rim, and the type of wing venation. From Entomacis it differs primarily by the structure of the notauli, from Xenismarus by a nonexposed labrum, and from Doddius by the nonstriate cheeks.

Distribution: Specimens of Poecilopsilus were examined from the Valdivian forest of Chile and Argentina. At present only one species is described (Ogloblin, 1955).

BIOLOGY: Unknown.

\section{Spilomicrus Westwood \\ Figures 55a, 97}

Spilomicrus Westwood, 1832: 129.

Loxotropa Foerster, 1856: 122, 123, 126. Synonymized by Masner, 1964a: 123-155.

Hoplopria Ashmead, 1893: 385, 386, 388. NEW SYNONYMY.

Linkiola Kieffer, 1910b: 39. NEW SYNONYMY.

Eriopria Kieffer, 1910a: 693, 744. Synonymized by Masner, 1964a: 123-155.

Tritopria Kieffer, 1910a: 717, 748. Synonymized by Masner, 1964a: 123-155.

Cologlyptus Crawford, 1910: 123. Synonymized by Masner, in Krombein and Burks, 1967: 285305.

Scutellipria Szabo, 1961: 53-493. Synonymized by Masner, 1964a: 123-155.

Diagnosis ( $q$ ô): Predominantly mediumsized $(2.5-3.5 \mathrm{~mm})$, rarely smaller $(1 \mathrm{~mm})$ or larger $(3.5-7 \mathrm{~mm})$ individuals; body color predominantly black or brownish black, rarely light brown, reddish or orange, legs and often part of antenna contrastingly lighter; body smooth and highly shining, predominantly glabrous, without micropilosity, usually with sparse semierect to erect long hairs; hairy cushions usually present on postgena, side of pronotum and upper part of propleuron; foamy structures not developed; antennal shelf predominantly well developed with toruli interconnected with sharp carina, or rarely shelf absent with toruli more or less wide apart; A3 in male subequal to A4; anterior scutellar pit bifoveate; anterior margin of syntergite not flexed, but distinctly elevated above level of petiole, not notched medially, rarely with two hairy depressions anterolaterally; apex of female metasoma only shortly pointed, apical sternite short, not compressed.

DESCRIPTION ( $q$ ô): HEAD. Head in dorsal 
view subglobular with shelf and toruli often strongly projecting; toruli predominantly connected by carina, rarely toruli separated by declivity; temple usually short, receding; head in lateral view with antennal shelf well developed; level of torulus around middle of eye; eye subcircular to ovoid; oral carina moderately to well developed; postgenal cushion predominantly well developed, in some species quite strong; occipital flange always present, sharply defined, sometimes broad and strongly convex, rarely crenulate; head in frontal view with face moderately long; mandible short but strong, bidentate with lower tooth moderately to distinctly longer; clypeus moderately convex, anterior margin of clypeus often slightly arcuate, not flexed; epistomal sulcus moderately to distinctly indicated by declivities; labrum not exposed; tentorial pit present or absent; malar sulcus developed or absent; head in ventral view with hypostomal bridge not developed; palpi long and slender, palpal formula 5-2, maxillary palpus 4 often wedgelike; antenna in both sexes 13-segmented; A1 remarkably long and slender (female) or moderately long (male), with apical rim unarmed, only moderately emarginate ventrally, or rim produced laterally in two lamellate flaps (fig. 55a); female antenna with moderate, nonabrupt, multisegmented clava, A13 subequal in length or shorter than A12, often with ventral pit, clavomeres almost always distinctly flattened ventrally; male antenna typically filiform, with scattered short hairs, A3 subequal to A4, A4 almost always modified, with sharp longitudinal carina, rarely A3 or A5A7 with low carinae. MESOSOMA. Mesosoma generally short, usually as high as wide or wider than high, slightly to distinctly convex dorsally; prothorax in dorsal view with cervix strongly developed; pronotal shoulders often well developed, rounded, sometimes sharp; side of pronotum anteriorly with dense pilosity or hairy cushion; epomium predominantly absent, rarely developed, and then quite sharp, with adjacent transverse rugulae; posterior margin of pronotum (between forecoxa and spiracle) noncrenulate or transverse ridges, but with single row of short hairs; propleuron generally hairy, sometimes with hairy cushion; mesoscutum usually as long as wide, moderately to strongly convex, rarely flattened; parapsidal and anterior parallel lines developed or absent; notaulus complete, noncrenulate, abbreviate anteriorly, or absent; humeral and suprahumeral sulci developed or absent, noncrenulate; anterior scutellar pit bifoveate, pits shallow or absent in short-winged species; scutellar disc subrectangular or subquadrate, rarely sharply ridged medially, with sharp lateral keels and deep lateral scutellar pits very, rarely lateral pits not developed; posterior scutellar pits usually present, rarely absent, axillar pit present or absent; posterior margin of axilla usually sharp, rarely rounded; axillar depression large, deep, often with dense pilosity; mesopleuron moderately convex, oblique median depression usually well developed; epicnemial pit always present, smooth; sternaulus present or absent; posterior margin of mesopleuron predominantly noncrenulate or pits; metanotum moderately developed; dorsellum usually with three keels, keels rarely sharp to bladelike; metapleuron concave anteriorly, usually coarsely rugose and densely hairy; propodeum moderately to distinctly elongate, median keel usually well developed, often produced into long spine directed upward, or backward; plica moderately to strongly developed; posterior margin of propodeum usually angularly excised, sometimes with strong rim and with posterolateral corners moderately projecting; side of propodeum rugose and densely hairy; forewing usually long and slender, perfectly rounded apically, hyaline, infuscate or sometimes maculate, marginal cilia moderately to fairly long; wing venation reaching to middle of wing length; costa usually less distinctly tracheate than submarginal vein, rarely costa hyaline or absent; costal cell relatively broad, rarely more narrow; marginal vein typically slightly elongate, less frequently distinctly elongate or short, thick, almost spotlike; stigmal vein slanted, short, at most subequal to marginal vein; postmarginal vein rudimentary or absent; basal vein at most nebulous, slightly to distinctly arcuate, slanted at acute angle toward submarginal vein; basal part of Rs2 and posterior part of $\mathrm{M}$ at most weakly nebulous; forewing sometimes with whitish longitudinal streak; hind wing with submarginal vein tracheate or hyaline; wings may be reduced to absent, mostly in females, rare- 
ly in both sexes; legs moderately elongate and slender, especially trochanters and hind tibiae, claws sometimes very strong, apices of mid and hind femora often produced into lamellate flaps. METASOMA. Metasoma moderate- to long-pedunculate; petiole moderately to remarkably elongate, pencil-like, slightly to distinctly expanded anteriorly over nucha, typically with longitudinal carinae or costae, less frequently with irregular sculpture, at least partly glabrous dorsally, densely hairy (sometimes with cushion ventrally); metasoma past petiole elongate ovoid, moderately wider than high, considerably flattered, at most only moderately convex dorsally; anterior margin of syntergite not flexed but distinctly elevated above level of petiole, not notched medially, exceptionally with two hairy depressions anterolaterally; apex of female metasoma only shortly pointed, with short, noncompressed apical sternite; apical sternite and apex of ovipositor valves rarely with dense stiff pegs or patch of dense pilosity; base of S2 without keels but often with cushion of hairs.

RECOGNITION AND RELATIONSHIPS: Spilomicrus is a large polytypic genus; in the past, several marginal species groups were given generic rank, especially in the Neotropic region. Among the Spilomicrini, Spilomicrus differs from Pentapria by bifoveate anterior scutellar pit, entire (not notched) anterior margin of syntergite, and lack of deep longitudinal groove on side of pronotum. From Entomacis it differs also by the bifoveate anterior scutellar pit, furthermore by the ratio of the marginal versus the stigmal veins and the strong development of the antennal shelf connecting the toruli. From Paramesius it differs by the shorter marginal vein and relatively short, nonconical shape of female apical sternite.

DisTRIBUTION: In the New World there are a large number of species occurring from Canada to Chile, with maximum diversity attained in both lowland and high elevations of the New World tropics. Masner (1991) keyed 21 species in the Nearctic region.

BIOLOGY: The ground plan biology is primary parasitism (both solitary and gregarious) of various Diptera; a few species were reared from Coleoptera. There are no spe- cialized myrmecophiles among New World species.

\section{Xenismarus Ogloblin \\ Figure 101}

Xenismarus Ogloblin, 1959: 43-46.

Diagnosis ( $q$ đ): Small to medium-sized individuals $(2-4 \mathrm{~mm})$; body color from light to dark brown, rarely almost orange-brown, body smooth and highly shining, rarely head densely punctate, with abundant pilosity on head and dorsal side of mesosoma including propodeum; foamy structures and hairy cushions not developed; antennal shelf not developed, toruli wide apart, not connected with carina; labrum broadly exposed; antennal formula 14-14; rim of A1 only slightly emarginate ventrally; anterior scutellar pit divided by narrow septum; apex of abdomen in female conical, long-pointed, apical sternite plow-shaped.

DESCRIPTION ( $q$ †): HEAD. Head in dorsal view transverse, subrectangular; temples moderately long, strongly receding; toruli separated by broad gap, not connected by carina; head in lateral view with antennal shelf not developed; level of torulus in middle of eye; eye ovate, with ommatidia relatively large; oral carina not developed; postgenal cushion not developed; occipital flange short, sharply defined, weakly crenulate; head in frontal view with short face; mandible strong, bidentate, with upper tooth slightly longer; clypeus moderately convex, wider than high; tentorial pit large; labrum broadly exposed; malar sulcus developed; cheek not striate; head in ventral view with hypostomal bridge not developed; palpi long and slender, palpal formula 5-2; antennal formula 14-14; A1 long and slender with rim only slightly emarginate ventrally, A1 distinctly longer than A3 ( $q$ o ), female antenna without clava, segments almost beadlike, not flattened ventrally, A14 only slightly longer than A13; male antenna filiform, with dense semierect hairs; A4 only slightly bent, with sharp longitudinal carina. MESOSOMA. Mesosoma generally short, usually as high as wide, moderately convex dorsally; prothorax in dorsal view with rounded shoulders; side of pronotum without hairy cushion, with no epomium and with some crenulae or rugu- 
losity above forecoxa (along posterior margin); mesoscutum moderately convex; parapsidal and anterior parallel lines absent or weakly defined; notaulus complete, slightly dilated posteriorly, noncrenulate; humeral and suprahumeral sulci narrow but deeply impressed, noncrenulate; anterior scutellar pit large, transverse oval, with distinct longitudinal ridges on bottom, median septum often developed; scutellar disc subquadrate, posterolateral corners sometimes slightly pointed or ridged; lateral keels developed or absent; lateral scutellar pits absent; posterior scutellar pits well developed; posterior margin of axilla rounded; axillar depression large, deep, usually with rough sculpture, almost glabrous; mesopleuron moderately convex, with only very shallow median oblique depression, posterior margin with incomplete chain of crenulae or ridges; epicnemial pit strongly developed, often with rough sculpture or ridges; sternaulus not developed; metanotum relatively broad, dorsellum with three minute keels; metapleuron deeply excavate, rugulose to rugose with abundant pilosity; propodeum in dorsal view short, rugose, usually hairy, median keel weakly developed, plica absent, posterolateral corners of propodeum moderately projecting, posterior margin of propodeum ridgelike; nucha short; forewing rounded apically, costa hyaline, submarginal vein distinctly remote from foremargin, hence costal cell relatively broad, marginal vein attaining about half wing length, distinctly elongate, subequal in length to perpendicular stigmal vein, postmarginal vein rudimentary, basal vein tracheate or nebulous, at most slightly arcuate, joining submarginal vein at acute angle, medial cubital and Rs veins at most nebulous; hind wing with strong tracheate submarginal vein, and nebulous basal vein; legs moderately strong, anterior constricted part of femora shorter than posterior clavate part. METASOMA. Petiole slightly elongate, cylindrical, with fine longitudinal rugulosity or keels, with only scattered pilosity; in lateral view, anterior face of petiole remarkably backward slanting; anterior margin of syntergite slightly flexed, with deep median slit, apex of female metasoma distinctly conical, pointed, apical sternite moderately to consid- erably compressed; base of S2 distinctly flexed, with no lateral keels.

RECOGNITION AND RELATIONSHIPS: Xenismarus is one of the most plesiomorphic genera of Spilomicrini as exemplified by its antennal formula (14-14). It is related to more plesiomorphic species of Entomacis (e.g., in Chile), and also to Poecilopsilus and Doddius, especially in the structure of toruli and shape of rim on A1. Xenismarus differs from all genera above by the antennal formula, furthermore, from Poecilopsilus by the reduced armature of the dorsellum, from Doddius by the nonstriate cheek, and from Entomacis by the broadly exposed labrum and conically pointed metasoma in the female.

DistRIBUTION: We examined specimens of Xenismarus from the Valdivian forest of Chile and Argentina; one undescribed species is known to us from the Juan Fernandez Islands (Chile).

\section{BIOLOGY: Unknown.}

\section{TRIBE DIAPRIINI ASHMEAD 1893}

DiAgnosis Predominantly small to medium-sized individuals, less frequently large individuals; body predominantly black or dark brown, sometimes lighter, orange to yellow, smooth and shining, hairy cushions and foamy structures usually well developed; postgenal cushion predominantly well developed; epistomal sulcus and tentorial pit not developed, labrum not exposed; malar sulcus very rarely developed; mandibles generally bidentate and clasped, rarely tridentate or modified and more or less projecting; mandibular condyle with only moderate rim; hypostomal bridge present; ground plan of antennal formula $12-14$, rarely antennal formula $13-14$ or $11-14$, female clava usually well developed, nonabrupt, rarely abrupt, 34-segmented, male antenna polytypic, antennomeres usually elongate, often verticillate, with long bristles arranged in whorls, rarely antennomeres penicillate to quadrate; pronotum in dorsal view usually moderately developed, pronotal shoulders rarely projecting, pronotum and propleuron usually with hairy cushion or foamy structures; mesoscutum slightly to strongly convex, often almost flat, notaulus and humeral sulcus never developed, admedian and parapsidal lines rarely 
present; anterior scutellar pit single, very rarely subdivided into two or often pit absent, axillar, lateral and posterior scutellar pits always absent, scutellar disc usually slightly convex to flat, often with median keel or armed with spine; epicnemial pit absent, sternaulus usually not developed, rarely at most rudimentary, never complete; metasternum often with foamy structures; propodeum usually with distinct median keel and plicae, rarely keel produced into long sharp spine, or modified, or keel reduced or absent, plical area usually less pubescent to almost glabrous, but not smooth; forewing usually surpassing tip of metasoma, often wing shortened to absent, venation relatively reduced, submarginal vein usually relatively short, approximated to foremargin of wing, costal vein absent, costal cell rather narrow to almost indistinct; basal vein usually not developed, but often indicated by short perpendicular vein, or infuscate transverse band below marginal vein; metasoma past petiole usually subglobular or slightly elongate, often sharply conical apically in female; T2 and T3 fused in large syntergite; S2 anterolaterally with at most patches of pilosity but no deep depressions (hairy depressions present in several genera), specialized spot developed in most symphilic genera, apical sternite in female typically pointed.

REMARKS: The tribe Diapriini is interpreted here in the classical sense. At present, we classify 33 genera, represented in the New World: Acanthopria Ashmead; Apopria, new genus; Asolenopsia Kieffer; Auxopaedeutes Brues; Avoca, new genus; Basalys Westwood; Bruesopria Wing; Cruzium, new genus; Diapria Latreille Doliopria Kieffer; Ecitovagus Masner; Eladio, new genus; Hansona, new genus; Labidopria Wasmann; Leucopria, new genus; Megaplastopria Ashmead; Mimopria Holmgren; Mimopriella, new genus; Mitropria Ogloblin; Monelata Foerster; Myrmecopria Ashmead; Neivapria Borgmeier; Notoxoides Ashmead; Omopria, new genus; Philolestoides Ferrière; Platymiscus Westwood; Psychopria, new genus; Szelenyiopria Fabritius; Szelenyisca Masner; Townesella Huggert and Masner; Trichopria Ashmead; Turripria, new genus; and Xanthopria Brues. This is probably the most speciose, diverse, and most apomorphic tribe of the subfamily Diapriinae. Diapriini is the only tribe that includes all true symphilic genera, some of them considerably adapted morphologically to life with ants; these adaptations include far-reaching mimicry with the host ants including the type of sculpture, pilosity, color, behavior, and biology. The biological ground plan is primary parasitism (solitary or gregarious) of various Diptera; several species were reared from coleopterous hosts, members associated with ants are known or assumed to parasitize ant larvae; some species are aquatic.

\section{Acanthopria Ashmead \\ Figures 1, 2, 3, 4, 5}

Acanthopria Ashmead, 1895: 742-821.

Adelioneiva Fischer, 1940: 397-401. NEW SYNONYMY.

Diagnosis $(q$ đ) $)$ : Small to medium-sized individuals (1.5 to $3.5 \mathrm{~mm}$ ); body color variable, from dark brown to typically light colored, light brown, yellow, orange or ferrugineous, smooth and shining, very rarely with areas of fine coriaceous sculpture, in few species head and mesosoma matte and finely coriaceous, in one species almost entire body sculptured; body predominantly glabrous, usually with sparse semierect hairs dorsally, rarely hairs transformed into strong, appressed whitish setae; foamy structures almost always on propleuron, metasternum, axillar depressions, sides of petiole, and often also on anterior side of pronotum; foretibia without dorsal spine; female clava nonabrupt, with at least five segments, clava often spindlelike, usually widest near middle, not broadened toward apex, with apical segment subequal in size to or even smaller than foregoing clavomeres; male antenna with A3 and A4 almost fused; stigmal vein in forewing relatively well developed; female metasoma past petiole rather short, subglobular, highly convex, with fine point only but never conical apically.

DESCRIPTION ( + ๙ ): HEAD. Head globular, hypognathous, with frons unarmed; antennal shelf moderate; level of toruli generally in middle of eye, rarely upper or lower middle of eye; face as wide as high, in lateral view convex, with upper half often flat; eye relatively large, eye height larger than half of 
head height, rarely smaller than half head height, eye ovoid, higher than wide, posterior orbit of eye often slightly sinuate, rarely straight; ommatidia often large and highly convex, in some species subequal in size to ocellus; mandible bidentate, normally equidentate; palpal formula 5-2; oral carina well developed; postgenal cushion not developed, postgena rarely with small cushion of dense and appressed pubescence or also sometimes with long large sparse hairs; female antenna generally spindlelike, normally 12 -segmented, very rarely 11-segmented, shape highly polytypic, clava when present, with five or more segments, often incrassate near middle, clavomeres cylindrical elongate, rectangular or quadrate, often subcompact, very rarely penicillate, not flattened ventrally, in some species brushlike with strongly transverse segments covered with dense flattened whitish setae (fig. 3); male antenna apparently with 13 segments, due to the partial fusion of A3 and A4; A3 and A4 sometimes with sharp carina on outer side; A5 to A14 knotted, with one whorl of bristles on each node; A7 to A12 without special brush of bristles;

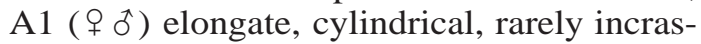
sate medially, unarmed apically. MESOSOMA. Mesosoma relatively short and subglobular; sides of pronotum convex; pronotal shoulders not developed; epomium rarely present; foamy structures always on propleuron and often on anterior sides of pronotum; mesoscutum broadly semicircular and highly convex in lateral view; anterior scutellar pit always present, large, rarely with longitudinal grooves; scutellar disc more or less trapezoidal, with lateral margins often slightly arcuate, disc generally flat or slightly convex, sometimes with median longitudinal keel, in numerous species armed with point or spine of various shapes; axillar depression well developed, posterior margin of axilla usually sharp, depression always with foamy structures, structures rarely rudimentary; mesopleuron convex, higher than wide, anterior and posterior margins running almost parallel and perpendicular to body axis; metapleuron and sides of propodeum pubescent, hairs rather long and semierect, permitting observation of propodeal sculpture, propodeum in some species with short dense pubescence, rarely completely glabrous; propodeal keel usually strongly produced and pointed anteriorly, point or spine facing backward, propodeal keel rarely almost spatulate; propodeal plicae well developed; wings always present, in some species relatively short and broad, racket-shaped, microtrichia usually abundant, sometimes strongly reduced to almost absent, wings generally clear without darker spots or bands, in some species bronze infuscate and highly glassy; submarginal vein moderately to distinctly curved up toward marginal vein and running strongly approximated to anterior margin of wing; stigmal vein relatively well developed; basal vein not developed or rarely indicated by delicate infuscation below stigmal vein; legs generally slender; femora more or less clavate; apex of anterior tibia without specialized spine dorsally; hind tibia without specialized brush of setae. METASOMA. Metasoma relatively short, widely overlapped by wings; petiole usually elongate, cylindrical, often with longitudinal keels, with abundant pilosity and foamy structures; metasoma past petiole globular, highly convex, with only fine point but never conical apically in female, in dorsal view subcampanulate, smooth and glabrous, except for row of setae posterior of large tergite and occasionally on subsequent tergites, with anterior margin of syntergite very narrow; anterior margin of S2 with flexed transparent rim; special spot on S2 absent; apical sternite in female almost glabrous, relatively short, not conical.

RECOGNITION AND RELATIONSHIPS: Acanthopria is one of the largest genera of Neotropical Diapriinae. Although only few species were described, we estimate the numbers to reach hundreds. Originally Acanthopria in females was recognized on the armed scutellum (Ashmead, 1893; Kieffer, 1916). The polytypic nature of Acanthopria in females is exemplified by a number of natural species groups, showing great diversity of character states. After examination of a large amount of material consisting of thousands of specimens (CNCI), we decided to interpret Acanthopria in a rather broad sense. Once better studied and with its biology known, the genus may be subdivided into several independent genera. Adelioneiva Fischer appears to us as one of those groups and we prefer to treat the genus as a junior synonym. Acan- 
thopria belongs to the tribe Diapriini; it is related both to the large genus Trichopria Ashmead, from which it differs principally by unarmed foretibia, male antennomeres A3 and A4 at least partly fused, and by female antenna nonabrupt and not broadened toward apex; furthermore, most Acanthopria species are distinguished by light color of body compared with generally much darker coloration of Trichopria species. Acanthopria shows also some relationships with myrmecophilic genera of the Diapriini such as Labidopria Wasmann; Leucopria, new genus; Mimopriella, new genus; etc. Acanthopria differs from them by the absence of specialized spot on $\mathrm{S} 2$ or by normal, i.e., noncompressed tarsi. Contrary to frequent coriaceous sculpture in ecitophilus genera, almost all species of Acanthopria known to us have smooth bodies. Acanthopria differs from Eladio, new genus, by the absence of a specialized comb of setae on hind tibia, and by nonsculptured body.

DistRIBUTION: Acanthopria is largely Neotropical in distribution, with only one undescribed species extending to Florida and two in Texas. The greatest species diversity seems to be in lowland rainforests of Central and South America. We examined specimens from Antilles, Mexico to Brazil, and north of Argentina. The genus is not represented in high elevations of tropical America (above $2500 \mathrm{~m}$ ) and does not occur in Chile.

Biology: The hosts are not known for any species. However, several observations (Ferrière, 1929; Borgmeier, 1939; Mann, 1918) indicate close association of Acanthopria species with ants (army ants, leafcutting ants). A series of females in CNCI was collected in Costa Rica rainforest attempting to enter a nest of leafcutting ants viz. Cyphomyrmex sp. (Attini). Nevertheless, Acanthopria species studied by us do not exhibit any advanced morphological adaptations as known among true myrmecophiles (e.g., Mimopria Holmgren; Mimopriella, new genus; Notoxoides Ashmead; Philolestoides Ferrière). Numerous light-colored species of Acanthopria are presumed to be nocturnal, as inferred from rich material collected in light traps in lowland Brazil and Panama (CNCI).

\author{
Apopria, new genus \\ Figures 8, 9
}

DiAgnosis ( $q$ ): Medium-sized individuals $(2.8 \mathrm{~mm})$, body ferrugineous, mesosoma and petiole predominantly rough rugulose, legs and antennae coriaceous with distinct pustulae, metasoma past petiole smooth and shining; entire body with long, abundant, semidecumbent, golden hairs, hairy cushions and foamy structures absent; eye and ocelli absent; palpi atrophied, palpal formula $0-0$; pronotum in dorsal view massively developed, subtruncate anteriorly, with broad shallow excavation anteromedially; tegula rudimentary, wings absent; upper part of mesopleuron above median oblique line with deep massive subtriangular depression; dorsellum strongly developed, bluntly tonguelike, only slightly shorter than scutellum; propodeum very long, horizontal, median keel and plicae absent, propodeum and petiole seemingly forming 2-segmented petiole; legs unusually large and robust; tibial spurs atrophied, formula $0-0-0$, tarsi strongly compressed, fore and middle basitarsi ventrally projecting into strong spine; petiole robust, subspherical.

DESCRIPTION ( $q$ ): HEAD. Head in dorsal view moderately elongate, frons armed with three minute points; antennal shelf large, weakly margined posteriorly; antennal shelf in lateral view distinctly projecting, toruli at level of middle of head; eye entirely absent; ocelli absent; oral carina minute; occipital flange not clearly defined; mandible bidentate, lower tooth distinctly longer than upper tooth; clypeus moderately convex, not clearly defined, epistomal sulcus and tentorial pit not developed; hypostomal bridge developed; palpi atrophied, palpal formula $0-0$; maxillae and labium present; antenna 12-segmented, nonclavate, A3 distinctly longest, longer than A2, A7-A11 slightly transverse, A12 spherical, slightly smaller than A11, A1 robust, cylindrical, slightly constricted basally, unarmed apically. MESOSOMA. Mesosoma distinctly elongate, almost boxlike, in lateral view from pronotum to propodeum almost at same level, considerably affected by apterism; pronotum and propodeum strongly developed, mesoscutum strongly reduced, all sutures well developed; pronotum in dorsal view massively developed, subtruncate an- 
teriorly, with broad shallow excavation anteromedially; shoulders subangularly projecting; sides of pronotum with rough rugulose sculpture; epomium not developed; mesoscutum reduced, relatively small, subtriangular, separated from pronotum by deep suture, slightly longer than wide, with rough rugulose sculpture, without sulci or lines; transscutal articulation developed; anterior scutellar pit relatively large and deep, almost smooth and shining, subtriangular, subequal in size to scutellar disc; scutellar disc relatively small, pillow-shaped, convex, without longitudinal keel, with rough rugulose sculpture; axilla strongly reduced, posterior margin of axilla rounded, axillar depression deep, irregular, without pilosity, posterior margin of scutellum semicircular, smooth and shining; tegula rudimentary, flat scalelike, smooth and shining; mesopleuron subtrapezoidal, entirely with rough rugulose sculpture, upper part of mesopleuron above median oblique line with deep massive subtriangular depression; sternaulus not developed; dorsellum subhorizontal, strongly developed, bluntly tonguelike, rugulose, without keels; metapleuron relatively large, with rough rugulose sculpture, anterodorsally with deep large subcircular depression, separated from propodeum by deep broad depression forming anterior constriction of propodeum; propodeum very long, in dorsal view elongate, subcampanulate, laterally (near spiracle) with deep depression running obliquely from posterior margin of dorsellum to base of hind coxa, forming here deep cleft, thus causing impression of 2-segmented petiole, propodeum in lateral view not sloping, horizontal, dorsal surface of propodeum evenly rugulose, median keel and plicae not developed, posterior margin of propodeum truncate; wings entirely absent; legs unusually long and robust, forefemur subclavate, median and hind femur cylindrical, tibia nonclavate, cylindrical, not projecting into spine apically, tibial spur formula $0-0-0$, tarsi strongly compressed, fore and middle basitarsi ventrally projecting into strong spine, basitarsus and following tarsomeres in fore and middle legs also slightly projecting ventrally. METASOMA. Petiole robust, slightly wider than propodeum, subspherical, entirely rugulose like propodeum, strongly constrict- ed posteriorly in front of syntergite, metasoma past petiole slightly elongated highly convex dorsally and ventrally, apex of metasoma shortly pointed, S2 with specialized spot anteromedially.

TyPE SPECIES: Apopria coveri, new species (described below), by present designation.

RECOGNITION AND RELATIONSHIPS: Apopria is recognized on number of unique, extreme apomorphic states reflecting its close association with the host ants: loss of eyes, ocelli, palpi, wings, and tibial spurs, furthermore by development of special projections on fore and mid basitarsi, presence of large deep depression on upper mesopleuron, as well as unique massive, tonguelike dorsellum. Apopria appears to share some character states with Ecitovagus and Myrmecopria; structure of propodeum and metasoma past petiole, as well as type of antenna, is shared with Ecitovagus; shape of head, reduction of palpi and tibial spurs, pustulae on femora and A1, are shared with Myrmecopria. The tendency to reduce palpi and tibial spurs, as a manifestation of a high degree of integration with the host ant, has started in Myrmecopria and culminates in Apopria.

ETYMOLOGY: The prefix apo (Greek for without) refers to loss of organs such as eyes, ocelli, palpi, and tibial spurs, the Latin word pria means "a little wasp". The gender is feminine.

MALE: Unknown.

Distribution: Two species are known to us from Florida.

Biology: Apopria coveri was originally collected from bivouac of ecitonine ant $\mathrm{Nei}$ vamyrmex opacithorax (Emery) (det. S. Cover) in the very center of the colony, deep underground, in total darkness. Judging from the loss of wings, eyes, and ocelli we assume that the life cycle and dispersal strategies of Apopria are entirely different from all symphilic genera of Diapriinae known to us in which eyes and ocelli are developed and wings primarily present (Huggert and Masner, 1983). A. coveri probably disperses underground with the newly budding colonies of the host ant. The second species, to be described later, sympatric with $A$. coveri, was collected in a colony of Neivamyrmex carolinensis (Emery) (det. M. Deyrup). 


\section{Apopria coveri, new species}

Figures 8, 9

DESCRIPTION: Holotype, $q$ : Length 2.8 mm, body ferrugineous; sculpture on head tends to become longitudinal especially on postgena and vertex, sculpture in ocular area generally finer and area irregularly concave; head length:width:height (45:39:42); head slightly wider than mesosoma (39:36); A1 robust, cylindrical, entirely sculptured, coriaceous reticulate, with distinctive dense, darker pustulae; antennal segments in relative proportions $(56: 13),(12: 10),(23: 12)$, (15:12), (13:11), (12:11), (10:12.5), (11:13), $(11: 13.5),(11: 14),(12: 15),(11: 13.5)$. MESOSOMA. Mesosoma length:width:height (100:36:36); anterolateral corners of pronotum with roughest sculpture of body, sides of pronotum in dorsal view narrower than width of mesoscutum (10:20); mesoscutum slightly longer than wide (23:20); scutellar pit slightly shorter than scutellar disc (8:10); tegula slightly smaller than scutellar pit; mesopleural depression almost smooth and shining on bottom; dorsellum slightly longer than scutellar disc (12:10); deep depression in anterolateral dorsal part of metapleuron almost smooth on bottom; sculpture of propodeum denser and more granular in comparison with rough rugulosity of pleura and pronotum; propodeum dorsally with shallow, longitudinal, indistinct declivity medially; forebasitarsus longer than tarsomeres 2-4 (25:20), spine on basitarsus exceeding on ventral side half length of tarsomere 2, tarsomere 2 wider than long, distinctly produced on ventral side in short spine, tarsomere 3 strongly transverse smaller than tarsomeres 2 and 4; mid basitarsus with strong spinelike projection ventrally, mid tarsomere 2 with row of four little spines ventrally; hind basitarsus elongate, all tarsomeres distinctly longer than wide, without spines ventrally. METASOMA. Petiole with same granular rugulosity as in propodeum, petiole slightly wider than posterior constricted part of propodeum (28: 25 ), petiole ventrally covered with shorter dense whitish semidecumbent hairs, narrow posterior constricted part of petiole (in front of syntergite) smooth and shining; metasoma past petiole rather robust, distinctly wider than mesosoma (62:36), longer than wide (105:62).

MALE: Unknown.

TyPe MATERIAL: $24+$. Holotype, $q$ (CNCI no. 22448), USA, Florida, Citrus Co., PineOak Estates, 7.9 mi NE Jct. Rt. 98 on Rt. 488, April 1 1993, S.P. Cover 3471; disturbed longleaf Pine-Turkey Oak woodland with grassy understory, bivouac under rotten pine stump; with Neivamyrmex opacithorax (Emery), det. S.P. Cover 1993. Holotype mounted on point, well preserved except for left mid tibia and tarsus and tarsomeres 3-5 of hind left leg missing. Paratypes, 23 우, USA, Florida, Alachua Co., Gainesville, $29^{\circ} 34^{\prime} 30^{\prime \prime} \mathrm{N}, 82^{\circ} 29^{\prime} 00^{\prime \prime} \mathrm{W}$, February 23 to May 23, 1991-1994, R. Lundgren, all associated with Neivamyrmex texanus Watkins (det. M. Deyrup) (CNCI, MIZA, NHM).

ETYMOLOGY: The new species is named in honor of Mr. Stefan Cover (Museum of Comparative Zoology, Cambridge, USA), who collected the first specimen (holotype). Mr. Cover also kindly supplied information on the biology and behavior of the host ant (see above).

DISTRIBUTION: Florida.

BIOLOGY: It is interesting to note that $A$. coveri is associated with both Neivamyrmex opacithorax and $N$. nigrescens. Mr. Lundgren (personal commun.) collected numerous individuals in spring under logs and rocks; the wasps moved with ants in a very similar manner, making their recognition rather difficult for the collector.

VARIATION: The only variations in the type series are slight differences in the body length.

\section{Asolenopsia Kieffer \\ Figures 10, 11, 12, 13, 14}

Asolenopsia Kieffer, 1921: 36-41.

Euplacopria Ferrière, 1929: 157. NEW SYNONYMY.

DiAgnosis ( $q \hat{o})$ : Small to medium-sized individuals (2 $\mathrm{mm}$ ); body light colored, yellowish brown to ferrugineous, predominantly smooth and shining, only sparsely hairy, with few long scattered hairs, hairy cushions or foamy structures moderately developed; eye distinctly higher than long, inverted droplike shape, with posterior orbit slightly sinuate, ommatidia large and convex, raspberry-like; 
frons unarmed, antennal shelf unmargined posteriorly; propodeum moderately long, sculpture well visible, finely rugulose, partly matte, median keel strongly developed, ridgelike to highly crestlike, not pointed anteriorly; plicae well developed; entire syntergite with scattered long semidecumbent hairs.

DESCRIPTION ( + ‡): HEAD. Head in dorsal view subglobular, frons unarmed, antennal shelf relatively small and shallow, unmargined posteriorly; temple behind eye relatively short, receding; torulus in level with lower half of eye; eye distinctly higher than long, inverted droplike shape with posterior orbit slightly sinuate, ommatidia large and convex, raspberry-like; oral carina minute to well developed; postgena with short pegs and appressed pilosity; occipital flange very narrow; mandible bidentate, lower tooth longer; hypostomal bridge well developed; palpi short, papal formula appearing 5-2; female antenna rather short, 11-12-segmented, with indistinct multisegmented clava (5-8 segments), clavomeres noncompact, with moderate gaps; male antenna appearing 13-segmented, A3 and A4 fused, A3 with two whorls of bristles, A4-A14 with one whorl of bristles each. MESOSOMA. Pronotum in dorsal view well developed at sides, pronotal shoulders sometimes strongly prominent, but pronotum behind shoulders almost abruptly flexed, anterior margin of pronotum with hairy cushions, propleuron with foamy structures and dense short pilosity; mesoscutum about as long as wide, moderately convex, parapsidal and anterior parallel lines not developed; anterior scutellar pit rather large, transverse, shorter than scutellar disc; scutellar disc subcircular to subquadrate, only moderately convex, only rarely elevated, median keel not developed, lateral keels remarkably sharp, sometimes elevated; posterior margin of axilla sharp, axillar depression deeply excavate, with foamy structures; mesopleuron relatively flat or with 2 convexities, oblique median line weakly indicated; dorsellum well developed, at least lateral keels sharp; metapleuron rather matte, finely rugulose with more abundant pilosity; metasternum with foamy structures and no furca; propodeum moderately long, with only scattered pilosity, sculpture well visible, fine- ly rugulose, partly matte, median keel strongly developed, ridgelike, sometimes crestlike, not pointed anteriorly; plica well developed; posterior margin of propodeum sometimes produced in laminae; wings primarily developed, relatively long and narrow, anterior margin of forewing sometimes slightly wavering, stigmal vein relatively well developed, sometimes strongly incrassate, almost spherical, forewing behind stigmal vein often with transverse band of specialized zone of strong and curved microtrichia on both sides, wings frequently lost (alectomy or bitten off); legs long and slender, with little modification except for moderately compressed tarsi. METASOMA. Petiole in dorsal view subquadrate to slightly transverse or distinctly elongate, cylindrical, almost smooth, without keels, partly covered with pilosity; metasoma past petiole moderately to distinctly convex, entire syntergite usually with scattered, long, semidecumbent hairs; specialized spot an S2 not developed.

RECOGNITION AND RELATIONSHIPS: Asolenopsia is presented here in the broader sense, i.e., including Euplacopria as a junior synonym. Asolenopsia gibba, new species, illustrates another borderline state of characters in Asolenopsia; originally we thought it may represent an independent genus. The important synapomorphy of Asolenopsia is the shape of the eye, which is somewhat inverted and droplike, with the posterior orbit slightly sinuate, and with the ommatidia large and raspberry-like. The differences in number of antennomeres as well as the armature of the propodeum appear to blend gradually in larger material already at hand (CNCI).

Distribution: Tropical lowlands of Central and South America.

BIOLOGY: Members of Asolenopsia are moderately to highly specialized associates of ecitonine ants (Neivamyrmex, Labidus, Eciton) (Loiácono, 1981). Their wings are primarily developed but subsequently bitten off by ants or cast off spontaneously (alectomy). Winged adults are also collected in light traps.

Asolenopsia gibba, new species Figures 10, 12

DESCRIPTIOn: Holotype, $q$ : Length $2 \mathrm{~mm}$; body entirely ferrugineous-brown, antennae 
and legs slightly lighter, metasoma past petiole darker; forewing almost clear, with slight yellowish tinge, especially in area of basal and median veins; parts of body with fine to rough granular microsculpture as follows: posteromedian part of occiput, frons along inner orbit and below toruli, ventral side of scapus, pronotal shoulders dorsally, margins of anterior scutellar pit, most of scutellar disc, metanotum, dorsellum, posteroventral corner of mesopleuron, entire metapleuron, entire propodeum and petiole, all coxae, finer granulation on A1, all femora and tibiae; side of pronotum medially with horizontally running fine rugulosities; remaining parts of body smooth and shining; body pilosity light yellow. HEAD. Head in dorsal view slightly wider than long (48:44); head in lateral view distinctly higher than long (52:44); temple, opposite to pronotal shoulder, deeply excavate; eye distinctly higher than long (30:19); posterior orbit slightly sinuate; eye distinctly larger than malar space (30:10); female antenna with 12 segments, antennal segments in relative proportions $(55: 11),(10: 8),(15$ : 7), (14:9), (12:10), (11:11), (7:11), (9:12), (9: 12), (10:12), (11:12), (18:12). MESOSOMA. Mesosoma in relative proportions length/ width/height (87:56:65); vertical part of pronotal shoulders with dense brush of yellowish pilosity; mesoscutum slightly longer than wide (41:39); anterior scutellar pit subcircular, slightly shorter than length of scutellar disc; scutellar disc highly elevated, humped dorsal surface slightly concave; propodeal keel bluntly projecting anteriorly, in lateral view enclosing hole formed from opposite side by longitudinal keels of dorsellum; venation in forewing not exceeding basal third of wing length (80:220). METASOMA. Petiole slightly wider than long (17:15); anterior margin of syntergite as wide as petiole $(17: 17)$, posterior part of syntergite without micropunctures; cercus in large subcircular depression.

Male: Allotype. Very dissimilar to female; generally much darker, granular microsculpture reduced only to pronotal shoulders; temple opposite to pronotal shoulder not excavate; scutellar disc less humped; antenna generally similar to males of Acanthopria, apparently 13-segmented, A3 partly fused with A4, A4 to A14 stalked proximal- 1y, A3 with two whorls of bristles, A4-A14 with one whorl of long bristles, A4 not modify, without spine or carina.

TyPe Material: $7 q, 10$. Holotype, $q$ (CNCI no. 22449), COSTA RICA, Heredia, Pto. Viejo, $50 \mathrm{~m}$ rainforest, February 1980, W. Mason. Allotype, 10 (CNCI), PANAMA, Bocas del Toro, Rio La Gloria, $8 \mathrm{~km}$ W. Rambala, $8^{\circ} 59^{\prime} 4^{\prime \prime} \mathrm{N}-82^{\circ} 13^{\prime} 57^{\prime \prime} \mathrm{W}, 35 \mathrm{~m}$, January 8, 2001, sweeping, trail in rainforest, J.L.García. Paratypes (CNCI, MIUP, MIZA): 1 $q$, COSTA RICA, Heredia, Braulio Carillo National Park, 400-500 m, April 11, 1985, trail in rainforest, L. Masner s.s. (metasoma and petiole glued aside); $1 \%$, Limon, Hitoy Cerere Biological Reserve, 100 m, January 14-18, 1991, J.S. Noyes: 1 9 , Guanacaste GCA, Est. Pitilla, 750 m, February 27, 1996, MT \& YPT, J. Noyes: 19 , PANAMA, Bocas del Toro, P.N. La Amistad, Wekso-Teribe, 50 m, October 17-24, 1999, YPT, A. Santos; $2 q$, same as allotype.

ETYMOLOGY: Gibba (Latin) in reference to humped shape of the scutellum. The gender is feminine.

Distribution: Costa Rica, Panama.

BIOLOGY: Unknown.

VARIATION: Very little variation was encountered in seven females studied.

\section{Auxopaedeutes Brues}

Figures 15, 16, 17, 18, 19

Auxopaedeutes Brues, 1903: 119-128.

Cracinopria Fouts, 1924: 159-166. Synonymized by Masner, 1964a: 123-155.

Diagnosis ( $q$ o): Small-sized individuals (about $1 \mathrm{~mm}$ ), body light to dark brown, smooth and highly shining, with fine scattered pubescence, sometimes predominantly glabrous; hairy cushions present, foamy structures absent (Nearctic) or present (Antilles); oral carina absent; palpi extremely short and minute, palpal formula appearing 2-1; female A4-A9 transverse or beadlike; A1 moderately to strongly compressed, usually slightly wider basally than apically; propodeum rather short and broad, deeply Ushaped excavate medially, excavation reaching almost to posterior margin of dorsellum, leaving no median keel, sides of propodeum projecting posteriorly; submarginal vein relatively short, not exceeding basal quarter of 
wing length; metasoma past petiole relatively large and massive in females, with anterior margin remarkably broad, distinctly wider than petiole; S2 anterolaterally with two hairy depressions.

DESCRIPTION ( 9 ô): HEAD. Head in dorsal view globular, frons unarmed, antennal shelf sometimes very large and deep, not margined posteriorly; head in lateral view with antennal shelf moderately projecting, torulus in middle to upper level of eye; eye subcircular, distinctly smaller in females than males, posterior orbit of eye rounded; ommatidia small and flat, not raspberry-like; oral carina absent; postgenal cushion relatively small or absent; occipital flange minute; hypostomal bridge well developed; mandible bidentate; palpi extremely short and minute, palpal formula appearing 2-1; female antenna 12-segmented, generally short and stout, clava semiabrupt to abrupt, 2-4-segmented, A4-A9 transverse or penicillate, A2 subrectangular in dorsal view, A12 without pit ventrally; A1

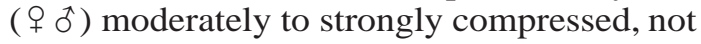
armed apically, usually slightly wider basally than apically; male antenna 14-segmented, rather short, A5-A14 beadlike with random long bristles, A3 and A4 large, sexually modified, A4 deeply emarginate with sharp carina; special brushes not developed. MESOSOMA. Pronotum in dorsal view moderately to strongly developed; pronotal shoulders prominent in some species; side of pronotum slightly convex, epomium not developed; pronotal cushion strong, moderate or absent; mesoscutum as long as wide, only slightly convex or flat, parapsidal lines, anterior parallel lines and humeral sulci absent; anterior scutellar pit of various shapes, usually shallow, smaller than scutellar disc; scutellar disc pillow-shaped, at most with moderate longitudinal keel, lateral keels moderately developed; posterior margin of axilla almost rounded, axillar depression very small, rarely with foamy structures; mesopleuron rather flat, submedian oblique line very weak or absent; sternaulus not developed; dorsellum weakly developed; metapleuron entirely covered with appressed fine pilosity; propodeum strongly modified, rather short and broad, deeply U-shaped excavate medially, excavation reaching almost to posterior margin of dorsellum leaving no median keel, plica not developed, sides of propodeum usually projecting posteriorly; wings primarily present and clear, basal vein not indicated, submarginal vein relatively short, not exceeding basal quarter of wing length, submarginal vein slightly upcurved; wings sometimes rudimentary or absent (bitten off by ant host); legs relatively short and stout especially in female, foretibia with strong dorsal spine. METASOMA. Petiole broadly transverse, densely hairy, in lateral view not projecting above syntergite; metasoma past petiole relatively large and massive in females, with anterior margin remarkably broad, distinctly wider than petiole, with anterolateral corners subrectangular, syntergite in lateral view only slightly convex, sometimes deeply excavate anteromedially, glabrous or with scattered pilosity; apex of female metasoma rather obtuse; S2 anterolaterally with two hairy depressions.

RECOGNITION AND RELATIONSHIPS: Auxopaedeutes is interpreted here as a specialized lineage of Trichopria from which it differs principally by highly modified propodeum. Auxopaedeutes differs from Bruesopria by the lack of constriction between the metathorax and the propodeum, also by having the metapleuron entirely covered with dense pilosity and by the two hairy pits anterolaterally on $\mathrm{S} 2$.

DisTRIBUTION: Six species were described from the Nearctic region; one undescribed species is known to us from Mexico (Tamaulipas) and one from Antilles (Hispaniola), the latter classified in Auxopaedeutes with doubts.

Biology: Two Nearctic species were collected from nests of the ant genus Solenopsis. Wings are occasionally clipped off by ants. Curiously enough, we studied an undescribed Nearctic species (USNM) that was reared from a tachinid, a primary parasitoid of diprionine sawflies (Symphyta). Fouts (1924) reported some species found in wheat.

\section{Avoca, new genus}

Figure 20

Diagnosis ( $q$ đ): Medium-sized (around 2 $\mathrm{mm}$ ) individuals; body color dark brown to almost black; body remarkably glabrous, with only scattered short hairs, in contrast 
with massive hairy cushions or areas of unusually dense pilosity; foamy structures not developed; female antenna 12-segmented, without clava, A4-A11 almost beadlike, uniform, not flattened ventrally, A12 without specialized ventral pit; male antenna 14-segmented, A4 with strong spine, A5-A13 beadlike, only slightly longer than wide, with dense scattered bristles; postgena with hairy cushion; pronotum dorsally and along anterior margin and entire propleuron with massive hairy cushion; scutellar disc distinctly concave, with lateral keels raised; axillar depression large, deep, filled with long dense pilosity; metanotum, especially dorsellum, metapleuron and propodeum with long, dense light-colored pilosity dorsally; anterior margin of syntergite not notched or emarginate medially.

DESCRIPTION ( $q$ o $)$ : HEAD. Head in dorsal view subglobular with antennal shelf and toruli moderately projecting, antennal shelf between toruli continuous, not emarginate; frons unarmed; temples relatively large, rounded; head in lateral view about as long as high; level of toruli in middle of eye; eye ovoid, relatively large; posterior orbit of eye not sinuate; ommatidia only moderately large, nonconvex; oral carina only moderately projecting anteriorly; postgenal cushion strongly developed; occipital flange, minute, not steplike; head in frontal view with clypeus broad; epistomal sulcus replaced by slight depression; tentorial pits rudimentary; malar sulcus not developed; mandible short, clasped, bidentate, lower tooth distinctly longer; palpal formula 5-2; head in ventral view with hypostomal bridge present; female antenna 12-segmented, without clava, A4-A11 almost beadlike, uniform, not flattened ventrally, A12 without specialized ventral pit; male antenna. MESOSOMA. Pronotum dorsally completely covered by massive hairy cushion; side of pronotum moderately convex, anterior margin with massive hairy cushion; epomium not developed; propleuron with massive hairy cushion; mesoscutum moderately convex with few scattered semierect hairs, with no sulci, lines, or depressions; anterior scutellar pit suboval, deep, without median keel; scutellar disc distinctly concave, with lateral keels raised, slightly sinuate and converging posteriorly, axillar, lateral and posterior scutellar pits not developed; axilla narrowly subrectangular, with sharp posterior margin; axillar depression large, deep, filled with long, dense pilosity; mesopleuron moderately convex, smooth, shining, almost glabrous, with median oblique depression rudimentary; epistomal pit absent; sternaulus not developed; posterior margin of mesopleuron noncrenulate; metanotum, especially dorsellum, with long, dense light-colored pilosity, dorsellar keels obscured by pilosity; metapleuron covered with long, dense light-colored pilosity; propodeum moderately large, with long, dense light-colored pilosity dorsally; median keel moderately developed, not pointed and not cresting anteriorly; plica not developed; posterior margin of propodeum not rimlike, posterolateral corners not projecting; nucha short and glabrous; forewing relatively large, with moderately long marginal cilia; submarginal vein strongly approximated to foremargin of wing; venation not exceeding basal forth of wing length, marginal vein short, stigmal vein as long as marginal vein; no other vein present; submarginal vein in hind wing incomplete; legs generally long and slender; femora strongly, tibiae moderately clavate distally; apex of femora without flaps; dorsal apex of foretibia shortly pointed, not produced in spike; tarsi not compressed. METASOMA. Petiole moderately elongate, with irregular keels mostly covered by dense pilosity on all sides; anterior margin of syntergite only slightly wider than petiole, distinctly elevated above level of petiole, not notched or emarginate medially; syntergite glabrous, with only few scattered erect hairs laterally; apical tergite small, almost vertical, not pointed; apical sternite short, broadly vomeriform, not conical apically.

TyPE SPECIES: Avoca collaris, new species (described below), by present designation.

RECOGNITION AND RELATIONSHIPS: Avoca is unique among all members of the Diapriini because of the apomorphic character states of the scutellar disc, pilosity of the axillar depression, metanotum, and propodeum. The nonclavate beadlike female antenna and the absence of a specialized spike on dorsal apex of foretibia will distinguish Avoca from such genera as Diapria and Trichopria. 
Etymology: Avoca is an euphonic anagram; the gender is feminine.

DisTRIBUTION: Avoca collaris (described below) is recorded from several localities in Florida and one in Georgia; additional specimens representing individuals from marginal populations or closely related species are known to us from Mexico (Chiapas), Antilles (Jamaica), Central America (Costa Rica), and South America (Ecuador).

Biology: Host unknown.

\section{Avoca collaris, new species}

Figure 20

DESCRIPTION: Holotype, $q$ : Length $2 \mathrm{~mm}$; body predominantly dark chestnut brown, legs including coxae, A1 yellowish brown, A2-A12 slightly darker, raised lateral keel of scutellar disc semitransparent, light brown; wings almost clear with slight yellowish tinge in anterior quarter. HEAD. Head in dorsal view slightly wider than long (45:37), slightly narrower than mesosoma (45:49); eye as long as temple (15:15), temple strongly receding; space between toruli subequal to half of torular diameter; antennal shelf between toruli entire, not emarginate; head in lateral view slightly higher than long (40:37); eye ovoid, higher than long (23:17), longer than postgena $(17: 12)$, distinctly larger than malar space (23:7); antennomeres in relative proportions (27:7), (9:5.5), (13:5), (10:6), (9: 6), (9:7), (9:7), (9:7), (8:7), (8:7), (8:7), (11: 6); A3-A12 with dense scattered hairs, length of hairs not exceeding width of segments. MESOSOMA. Mesosoma in dorsal view longer than wide (77:49); cervix of pronotum almost glabrous with fine rugulose sculpture; mesoscutum distinctly wider than long (43:30), moderately convex, distinctly declivous posterolaterally (near tegula), almost glabrous with only one pair of bristles in anterior half; scutellar pit slightly shorter than scutellar disc (9:13). METASOMA. Petiole moderately longer than wide (20:14); metasoma past petiole moderately elongate (74:46); syntergite glabrous, with only three or four long bristles situated on sides in anterior half, entire syntergite without micropunctures; S3-S6 with scattered setigerous punctures.

MALE: Unknown.
Type MAterial: $13 q$. Holotype, $q$ (CNCI no. 22450), USA, FL, Alachua Co., Gainesville (American Entomological Institute), September 15-October 27, 1987, BRC Hymenoptera Team, FIT in regrown oak forest. Paratypes: $2 q$, same data as holotype; 19 , February 23-June 2, 1988, D.B. Wahl; 2 , April 1991, D.B. Wahl, MT; 19 , June-July, 1987, FIT; 2 , July 14-24, 1987; 19 , July 15-August 2, 1987, FIT; 1 , September 21November 18, 1987, FIT; 1 , Jackson Co., Florida Cave State Park, June 9-July 11, 1981, S. \& B. Peck, FIT; 1 ㅇ, GA; McIntosh Co., Sapelo Is., June 1987, BRC Hymenoptera team, live oak forest, FIT.

ETYMOLOGY: Collaris (Latin) in reference to the massive hairy collar on pronotum.

MALE: Unknown.

DistRIBUTION: USA (Florida, Georgia).

BIOLOGY: Host unknown. The flight period in Florida and Georgia is from February to November; obviously the species has several generations per year.

VARIATION: The only variability encountered is in body color; several paratypes are slightly darker than the holotype.

\section{Basalys Westwood \\ Figures 21, 22}

Basalys Westwood, 1832: 342-344.

Ceratopria Ashmead, 1893: 407, 42. Synonymized by Masner, 1964b: 85 .

Acidopria Kieffer, 1913: 442. Synonymized by Masner, 1964b: 85.

Loxotropa auct. nec Foerster.

Nesopria Muesebeck and Walkley, 1956: 319419. Synonymized in Krombein et al., 1979: 1144.

Diagnosis ( $q$ đ): Small to medium-sized individuals $(1-3.5 \mathrm{~mm})$; body color from yellow to black, predominantly brown, smooth and shining, head and mesosoma with long scattered hairs, hairy cushions developed, foamy structures absent; antennal shelf usually distinctly prominent in both lateral and dorsal views; clypeus generally convex, sometimes almost keel-like; female antennal clava strongly abrupt, 3- or 4-segmented; forewing with submarginal vein moderately remote from foremargin of wing, venation distinctly surpassing basal third of wing length, stigmal vein often moderately developed, basal vein always present, 
straight, fully pigmented, perpendicular to but never contiguous with submarginal vein, positioned well before marginal vein.

DESCRIPTION ( $\left.\begin{array}{l}c \\ 0\end{array}\right)$ : HEAD. Head in dorsal view generally subangular to globose, sometimes elongate or slightly transverse; frons usually unarmed, sometimes with median sharp point or with two points anterolateral$1 y$, or rarely with ledges and rugulose sculpture; antennal shelf usually prominent anteriorly, not margined posteriorly, in lateral view usually distinctly prominent; toruli usually in level of lower eye; eye generally subcircular; posterior orbit of eye not sinuate; ommatidia moderately sized, not highly convex; oral carina well developed; postgenal cushion usually strongly developed; occipital flange moderate; mandible generally bidentate, normally clasped, sometimes strongly projecting, beaklike or almost opisthognathous; clypeus generally convex, sometimes almost keel-like; epistomal sulcus sometimes well developed; malar sulcus not developed; mandibular condyle often convex; hypostomal bridge well developed; palpal formula 5-2; female antenna 12-segmented, clava strongly abrupt, 3- or 4-segmented, clavomeres distinctly flattened ventrally, A12 subequal to A11, A12 never with special pit ventrally; articulation between A9, A10, and A11 in extreme dorsal part; A1 in both sexes cylindrical, usually unarmed apically, rarely with sharp apical rim; male antenna 14-segmented, A2 subspherical, A5-A14 usually elongate, with dense scattered hairs, A4 distinctly sexually modified, usually emarginate, with longitudinal keel, A3 usually subequal to or shorter than $\mathrm{A} 4$; specialized brushes rarely present on A8-A10. MESOSOMA. Pronotum in dorsal view moderately developed; pronotal shoulders not developed, epomium absent; pronotal cushion strongly developed; propleuron densely hairy; mesoscutum as long as wide, only slightly convex or flat, often with shallow (nonimpressed) declivities in anterior notaular region, sulci and lines not developed; anterior scutellar pit generally transverse-subrectangular or subcircular, rarely almost bifoveate, or pit not developed; scutellar disc subquadrate, predominantly flat, rarely with fine median keel, lateral keels of disc sometimes strongly developed, lateral scutellar pits rarely devel- oped; posterior margin of axilla finely rounded, axillar depression large, usually hairy; mesopleuron almost flat, oblique median line weak or absent; epicnemial pit not developed; sternaulus absent; dorsellum usually densely hairy, with three keels; metapleuron rugulose, generally hairy; propodeum relatively short, with strong median keel and well defined plica, area between plica and keel predominantly glabrous and smooth; forewing with submarginal vein remote from foremargin of wing by at least its width, venation distinctly surpassing basal third of wing length, stigmal vein often moderately developed, basal vein always present, straight, fully pigmented, perpendicular to but never contiguous with submarginal vein, positioned before marginal vein; hind wing with submarginal vein incomplete; wings often shortened in both sexes; legs slender, with femora and tibia clavate, tarsi not compressed, foretibia without dorsal spine apically. METASOMA. Petiole cylindrical, relatively short, usually densely hairy, rarely with specialized dense pilosity, or petiole dorsally partly glabrous, with longitudinal keels; metasoma past petiole moderately elongate, syntergite only slightly convex to almost flattened dorsally, generally glabrous but often with narrow strip of fine pilosity on anterior margin of syntergite, anterior margin of syntergite straight, not excised medially; S2 with two hairy depressions and generally dense pilosity anteriorly; female metasoma moderately pointed apically but not conical.

RECOGNITION AND RELATIONSHIPS: Basalys, as presently interpreted, comprises several former genera (see synonymies above). We recognize Basalys primarily on the unique venation of the forewing, especially the position and the shape of the basal vein. Antennal clava in the female is also diagnostic for the genus, 3- or 4-segmented and strongly abrupt. Basalys is closest to Doliopria; the two genera can be conveniently distinguished by the presence (Basalys) or absence (Doliopria) of the basal vein in the forewing, as well as by the form of antennal clava in the female.

DistRIBUTION: Basalys is well represented in both North and South America (rarely in Chile); the vast majority of species remain undescribed. 
Biology: Several species were reared from various dipterous hosts (Notton, 1991; Simmonds, 1953) and some were collected in ant nests.

\section{Bruesopria Wing}

Figures 25, 26

Bruesopria Wing, 1951: 195-210.

Diagnosis $(q \nless)$ : Small-sized individuals (about $1 \mathrm{~mm}$ ); female body light brown, males darker, smooth and highly shining, with fine scattered pubescence, hairy cushions developed, foamy structures absent; palpi extremely short and minute, palpal formula appearing 2-1; female antenna with abrupt 3-segmented clava; metapleuron predominantly glabrous, deeply excavate and almost smooth anteriorly, rugulose and strongly produced above hind coxae; propodeum in dorsal view separated from metathorax by strong constriction; petiole strongly modified, remarkably higher than long, fingerlike produced dorsally above anterior margin of syntergite; metasoma past petiole relatively large and massive in females, anterior margin remarkably broad, distinctly wider than petiole, with anterolateral corners subangular, entire syntergite with dense semierect pale hairs.

DESCRIPTION ( + đ): HEAD. Head in dorsal view globular, frons unarmed, antennal shelf remarkably small, not margined posteriorly; head in lateral view with antennal shelf only moderately projecting, level of torulus in lower half of eye; eye ovoid, subequal to malar space, distinctly smaller in females than males, posterior orbit of eye rounded; ommatidia small and flat, not raspberry-like; oral carina probably absent, covered by large postgenal cushion; occipital flange minute; face transverse, wider than high; mandible bidentate; hypostomal bridge present; palpi extremely short and minute, palpal formula appearing 2-1; female antenna 11-12-segmented, generally short and stout, with abrupt 3-segmented clava, A11 slightly larger than A10, A4-A 8 broadly transverse, A1 moderately to strongly compressed, not armed apically; male antenna 14-segmented, rather short, A5-A14 beadlike with random long bristles, A4 sexually modified with sharply pointed keel apically; special brushes not developed in male flagellum. MESOSOMA. Pronotum in dorsal view well developed; pronotal shoulders not developed; side of pronotum slightly convex, epomium not developed; pronotal cushion minute; propleuron densely hairy; mesoscutum as long as wide, almost flattened, covered with scattered fine semierect hairs; anterior parallel lines and humeral sulci absent; anterior scutellar pit relatively large, rather shallow, subrectangular, without longitudinal keels, smaller than scutellar disc; scutellar disc pillow-shaped, subcircular, lateral keels weakly developed; posterior margin of axilla almost rounded, axillar depression small, with fine pilosity; mesopleuron rather flat, submedian oblique line indicated by transparent darker line; sternaulus not developed; dorsellum weakly developed, keels indistinct; metapleuron predominantly glabrous, deeply excavate and almost smooth anteriorly, rugulose and strongly produced above hind coxae; propodeum in dorsal view separated from metathorax by strong constriction (i.e., excavate anterior part of metapleuron), posterior margin of propodeum with deep semicircular excavation, median keel of propodeum rudimentary, posterolateral corner of propodeum angularly projecting; wings primarily present, clear, basal vein not indicated, submarginal vein relatively short, not exceeding basal quarter of wing length; legs relatively short and stout, especially in female, mid tibiae slightly sinuate; tarsi short, stout, and not compressed, tarsomere 5 enlarged; apex of foretibia with strong dorsal spine. METASOMA. Petiole strongly modified, remarkably higher than long, fingerlike, produced dorsally above anterior margin of syntergite, with abundant pilosity apically; metasoma past petiole relatively large and massive in females, moderately convex dorsally, anterior margin remarkably broad, distinctly wider than petiole, with anterolateral corners subangular; entire syntergite with dense semierect pale hairs, syntergite moderately convex; S2 without depressions anterolaterally, with distinctly flexed semicircular rim anteromedially, without specialized spot.

ReCOGNITION AND RELATIONSHIPS: Bruesopria, like Auxopaedeutes, is interpreted here as a specialized lineage of Trichopria, with 
morphological adaptations for subterranean behavior and interaction with ants. Bruesopria differs from Auxopaedeutes principally in the structure of the propodeum, which is strongly constricted anteriorly due to deep excavation of the anterior part of the metapleuron. Bruesopria is closely related to $\mathrm{Pa}-$ learctic genera Solenopsia Wasmann and Lepidopria Kieffer; future studies may necessitate subsequent synonymy.

Distribution: Two species are described from America north of Mexico (Wing, 1951). We also examined an undescribed species associated with Solenopsis sp. in Arizona; the female antenna of the latter species is 12segmented.

BIOLOGY: Bruesopria aberrans (Brues) was found in a nest of the ant genus Solenopsis; the wings are frequently bitten off by host ants. Several closely related genera of Diapriini, all in the Northern Hemisphere, are also associated with Solenopsis ants: Auxopaedeutes, Solenopsia, Lepidopria, and Trichopria (part).

\section{Cruzium, new genus}

Figures 35, 36

Diagnosis ( $q$ ): Medium-sized (2.7 mm) robust individuals; body predominantly dark brown, some parts reddish, legs and antennae lighter, body smooth and highly shining, with only moderate pilosity, foamy structures present; female antenna 12-segmented, with moderate nonabrupt clava, clavomeres not flattened ventrally, A12 without ventral pit; legs remarkably short and stout; petiole large, robust, swollen vase-shaped, smooth and glabrous dorsally; apical sternite large, with massive carpet of dense, stiff, curved, yellowish pegs.

DESCRIPTION ( $q$ ): HEAD. Head in dorsal view globose, frons unarmed, antennal shelf well developed in front of toruli; temple moderately long; head in lateral view about as long as high, antennal shelf distinctly projecting, level of toruli at midpoint of eye; eye relatively large, subellipsoidal, with moderately large ommatidia; oral carina developed but partly obscured by pilosity of postgenal cushion, outer margin of postgena with patch of foamy structures; occipital flange developed, not distinctly steplike, noncrenulate; head in frontal view with face broad, clypeus almost flat; epistomal sulcus weakly indicated; labrum not exposed; malar sulcus not developed, area between lower orbit and mandibular condyle narrow; tentorial pit not developed; mandible clasped, strong, bidentate; palpi very short, palpal formula 5-2; head in frontal view with hypostomal bridge developed; antenna 12-segmented; A1 long, cylindrical, with apical rim not excavate ventrally, rim not produced into flaps; A4-A9 subcircular, almost beadlike; clava nonabrupt weakly 3-segmented, clavomeres not flattened ventrally, A12 without ventral pit. MESOSOMA. Mesosoma moderately long, slightly wider than high, considerably flattened dorsally, mesoscutum, scutellum, and propodeal keel almost at same level; prothorax in dorsal view with cervix strongly developed; pronotal shoulders moderately broad but not projecting; anterior margin of pronotal side with massive foamy structures, side of pronotum moderately concave, smooth, shining and glabrous, with only few scattered long bristles along dorsal margin; epomium not developed; spiracle on pronotum not spikelike; propleuron in upper part with massive foamy structures; mesoscutum subtrapezoidal, with few long semierect bristles; parapsidal and anterior parallel lines absent; humeral and posthumeral sulci not developed; anterior scutellar pit large but shallow, subrectangular, with weak median longitudinal keel; scutellar disc flat, subrectangular, with low lateral keels; axillar, lateral and posterior scutellar pits not developed; posterior margin of axilla rounded; axillar depression very small and shallow, with scattered pilosity; mesopleuron almost flat, smooth, shining, glabrous; median oblique depression not developed; sternaulus not developed, reduced to rudiment right above midcoxa; posterior margin of mesopleuron smooth, noncrenulate; metanotum relatively narrow; dorsellum with three short longitudinal keels, median keel weak; metapleuron densely hairy; propodeum large, relatively long; median keel strongly developed, crestlike with only minute point posteriorly; plica well developed, space between plica and median keel almost smooth and largely glabrous; posterior margin of propodeum rimlike, posterolateral corners distinctly angular; 
side of propodeum densely hairy; nucha very short; forewing relatively narrow, surpassing tip of metasoma, apex round, marginal cilia relatively long; marginal vein not surpassing basal quarter of wing length, submarginal vein strongly approximated to foremargin, no other veins developed; hind wing without tracheate submarginal vein; legs remarkably short and stout; femora strongly clavate, only twice as long as wide; apex of anterior tibia dorsally with short strong spine; middle and hind basitarsi shortened, shorter than apical tarsomere, all claws large and strong. METASOMA. Metasoma short pedunculate; petiole slightly longer than wide, large, robust, swollen vase-shaped, smooth and glabrous dorsally, with dense pilosity and longitudinal streak of foamy structures ventrally, with large patches of foamy structures posterolaterally; metasoma past petiole subrectangular, distinctly depressed, much wider than high, not pointed apically; anterior margin of syntergite entire, not notched medially, syntergite occupying almost entire surface of metasoma past petiole, following tergites extremely narrow; T8 and T9 extremely small, T9 bluntly triangular, not pointed; base of S2 anterolaterally with two large pits filled with foamy structures and pilosity; apical sternite large, as long as three preceding sternites combined, with massive carpet of dense, stiff, curved, yellowish pegs.

TyPE SPECIES: Cruzium amphorale, new species (described below), by present designation.

RECOGNITION AND RELATIONSHIPS: Cruzium differs from all genera of the tribe Diapriini in two strong apomorphies, viz. structure of the petiole and the presence of the specialized peggy carpet on the apical sternite. The short, strong legs are also unusual for members of this tribe. Cruzium shares with the Diapria complex a dorsal spine on the apex of the foretibia. The males of Cruzium are not known.

ETYMOLOGY: The generic name is in honor of Mr. Eladio Cruz, formerly a resident of Peñas Blancas (Costa Rica), the type locality of $C$. amphorale. The gender is neuter.

MALE: Unknown.

Distribution: At present, Cruzium amphorale, new species is known from the rainforests of Costa Rica; a closely related sec- ond species was caught in a Malaise trap in lowland rainforest in Ecuador (Sucumbios) (CNCI).

Biology: Host unknown. The highly specialized structure of the petiole and especially the unique peggy brush on the apical sternite indicate the possibility of an association with ants.

\section{Cruzium amphorale, new species}

Figures 35, 36

DESCRIPTION: Holotype, + : Length 2.7 $\mathrm{mm}$; head, mesosoma and metasoma generally dark brown, with lighter reddish tint on pronotal cervix, tegulae, nuchal region, legs including coxae uniformly orange-yellow, antenna reddish brown, A8-A12 dark brown, forewing slightly infuscate with light yellowish tinge. HEAD. Head in dorsal view slightly longer than wide (52:49); ocelli close together, POL considerably shorter than OOL; antennal shelf in front of toruli sharply carinate, not emarginate medially; space between toruli slightly shorter than diameter of torulus; head in lateral view slightly longer than high (52:47); eye distinctly higher than long (26:21), remarkably higher than malar space (26:6), longer than postgena, (21:16); head in frontal view with face slightly convex, smooth, with scattered setigerous punctures; antennal segments in relative proportions (43:9.5), (12:8), (14:8), (12:9), (11:9), (11:9.5), (10:10), (10:10), (10:11), (10:13), (11:14), (18:14). MESOSOMA. Mesosoma in dorsal view longer than wide (110:60); mesoscutum slightly wider than long (45: 43); anterior scutellar pit shorter than scutellar disc medially (11:15); posterior margin of propodeum broadly angular, invaginated medially; femora strongly clavate, only twice as long as wide, sharply carinate ventrally; mid basitarsus distinctly shorter than corresponding tarsomere 5 (7:11). METASOMA. Petiole large, robust, slightly longer than wide (45:30), swollen vase-shaped, smooth and glabrous dorsally, with several short irregular crenulae at anterior margin; syntergite only slightly longer than wide (77:69), almost entirely glabrous; T8 with long erect scattered bristles; apical sternite with row of long erect bristles in front of peggy cushion.

MALE: Unknown. 
TyPe MAterial: $2 q$. Holotype, $q$ (CNCI no. 22452), COSTA RICA, Alajuela, Peñas Blancas, 700 m, March 1987, E. Cruz, MT, primary rainforest. Paratypes, $1+$, same data as holotype.

ETYMOLOGY: The species name refers to the shape of the petiole resembling a Greek vase (amphora).

DisTRIBUTION: Costa Rica (rainforests on the eastern slopes of the Cordillera Tilarán range).

BIOLOGY: Host unknown.

VARIATION: No variation encountered in the two specimens examined.

\section{Diapria Latreille \\ Figure 38}

Diapria Latreille, 1796: 110.

Tropidopria Ashmead, 1893: 406, 407, 416. An objective junior synonym of Diapria Latreille.

DiAgnOSIS ( $q \hat{\jmath}$ ) : Medium-sized individuals (2.5-3.5 $\mathrm{mm}$ ); body predominantly dark, appendages lighter, body smooth and shining, generally glabrous but with scattered semierect bristles and strong hairy cushions, foamy structures not developed; female antenna with moderate, semiabrupt, multisegmented clava (5-6), clavomeres not flattened ventrally, A12 without specialized pit; male A3-A14 strongly elongate, subcylindrical not knotted, with random erect hairs not in whorls; scutellar pit large and deep, often with longitudinal ridges; anterior margin of syntergite raised, flexed and excised medially; apical sternite in female vomeriform, sharply conical.

DESCRIPTION ( $q$ o $)$ ): HEAD. Globose head, frons unarmed, antennal shelf moderate, not margined posteriorly; temple relatively large, rounded, anterior margin of antennal shelf only moderately projecting; level of toruli in middle of eye; eye subcircular, relatively small, posterior orbit of eye not sinuate, ommatidia small, nonconvex; ocelli normal; oral carina strongly developed; postgenal cushion strongly developed; occipital flange minute; mandible bidentate; clypeus with deep transverse sulcus above anterior margin, epistomal sulcus not developed, malar sulcus not developed, tentorial pits absent; hypostomal bridge well developed; papal formula 5-2; female antenna 12-segmented, with moder- ate, semiabrupt, multisegmented clava (5-6 segments), clavomeres subspherical, with distinct gaps, clavomeres slightly higher than wide, not flattened ventrally, A12 ventrally with no pit; male antenna 14-segmented, long and slender, A3 to A14 strongly elongate, subcylindrical, not knotted, with random erect hairs not in whorls, A3 and A4 or only A4 modified, with longitudinal carina, A4 always emarginate, A1 distinctly longer than A3; special brushes on A8-A10 or A8A12. MESOSOMA. Pronotum in dorsal view moderately developed, pronotal shoulders not developed, sides of pronotum flat, epomium not developed, anterior margin of pronotum and propleuron with massive cushions; mesoscutum moderately convex, with scattered semierect bristles, with no sulci, lines or depressions; anterior scutellar pit large and deep, often with longitudinal ridges; scutellar disc subrectangular, with strong median longitudinal keel; posterior margin of axilla moderately sharp, axillar depression with abundant appressed micropilosity; mesopleuron only slightly convex, with submedian oblique line rudimentary; sternaulus not developed; dorsellum densely hairy, with median keel stronger than lateral keels; metapleuron entirely covered with semiappressed silvery pilosity; propodeum rather short with distinct median keel raised medially, plica weakly developed, area between plica and keel hairy, posterior margin of propodeum V-shaped emarginate; wings always present, submarginal vein in forewing almost straight, reaching basal third of wing, stigmal vein rudimentary, basal vein not developed; submarginal vein in hind wing incomplete, indicated basally and apically near hamuli; legs generally slender, femora strongly, tibia moderately clavate distally, tarsi not compressed, apex of foretibia with long, slender spine dorsally. METASOMA. Petiole distinctly elongate, cylindrical, with irregular longitudinal keels and abundant pilosity both dorsally and ventrally; metasoma past petiole moderately convex, distinctly conical apically in female; anterior margin of syntergite raised, flexed, and excised medially; S2 basally with dense pilosity, specialized spot on S2 not developed, apical sternite in female vomeriform, sharply conical.

ReCOGNITION AND Relationships: Diapria 
has been traditionally recognized on the presence of the median excision and flexion of the anterior margin of the syntergite. The ground plan of Diapria is essentially identical with that of Trichopria, s.l.; however, several minor details are worth mentioning. Contrary to some Trichopria, foamy structures and the specialized pit on female A12 never occur in Diapria and female clavomeres are not flattened ventrally. Sundholm (1960) discussed the taxonomy of Diapria and allied genera.

DISTRIBUTION: Notton (1995) recognized four species in Britain. Diapria conica (Fabricius) is a widespread tramp species occurring throughout the world. We also examined several specimens of Diapria from Chile (CNCI).

BIOlogy: Diapria conica is a parasite of Eristalis tenax (L.) (Syrphidae) (Sanders, 1911).

\section{Doliopria Kieffer \\ Figures 41, 42, 43, 44}

Doliopria Kieffer, 1910a: 48.

Martinica Risbec, 1950: 533. NEW SYNONYMY.

Diagnosis ( $q$ o ): Predominantly small to rarely medium-sized individuals $(1-3.5 \mathrm{~mm})$; body color light yellow to dark brown, predominantly smooth and shining, head and mesosoma with abundant, scattered, long, semierect hairs, strong hairy cushions but no foamy structures; female antenna 11-, rarely 10-segmented, A10 and A11 largest, articulation between A9, A10, and A11 in extreme dorsal part; submarginal vein in forewing moderately to distinctly remote from foremargin; marginal and stigmal veins subtriangular in shape, stigmal vein often well defined, basal vein not developed; hind wing always with pigmented submarginal vein; anterior margin of syntergite straight and entire, often raised medially or almost flexed and moderately to distinctly excised medially; S2 anterolaterally with two hairy depressions.

DESCRIPTION ( $q$ o $)$ : HEAD. Head in dorsal view predominantly globose, sometimes transverse or produced anteriorly, usually smooth, sometimes with large, coarse punctures, frons usually unarmed, very rarely with small median point; antennal shelf relatively large, not margined posteriorly, in one undescribed species, partly margined; head in lateral view with antennal shelf moderately to distinctly projecting; level of torulus in the middle of the eye; eye usually subcircular, with posterior margin not sinuate, ommatidia relatively small and not convex; oral carina usually well developed, partly obscured by postgenal cushion; postgenal cushion strongly developed, sometimes contiguous ventrally across hypostomal bridge; occipital flange moderate to well developed; occiput usually rounded, sometimes sharply steplike carinate; face sometimes sculptured, rugulose or punctate, often with distinct depression medially below antennal shelf; mandible bidentate, rarely strongly enlarged, mandibular condyle usually with elevated rim; clypeus usually well defined, convex, epistomal sulcus sometimes well developed, rarely lower margin of clypeus flexed and bladelike projecting; rarely lower face deeply concave; tentorial pit and malar sulcus not developed; hypostomal bridge well developed, sometimes covered by part of postgenal cushions; palpal formula 5-2; female antenna 11-segmented, very rarely $10-$ segmented, usually strongly clavate, clava semiabrupt, gradually incrassate toward apex, A10 and A11 usually largest, A11 always larger than A10, A10 and A11 often distinctly flattened ventrally, A10 rarely with sharp spine, articulation between A9, A10 and A11 in extreme dorsal part, apical clavomere ventrally without pit; A1 elongate, cylindrical, without longitudinal keels, not armed apically; male antenna 14-segmented, A2 subspherical, A3-A14 usually cylindrical, rarely subpennicilate to almost verticillate, with dense, scattered hairs, A4 sexually modified or not; specialized brushes present on A8A11 or A9-A11, rarely not developed. MESOSOMA. Pronotum in dorsal view moderately developed, pronotal shoulders not developed, sides of pronotum moderately convex; epomium rarely developed but obscured by pronotal cushion; pronotal cushion usually strong and massive, consisting of densely packed fine pilosity, propleuron also densely hairy; mesoscutum only moderately convex, sometimes flat, lines, sulci, and depressions absent; anterior scutellar pit usually present, variable in shape, predominantly subcircular, rarely subbifoveate or absent; 
scutellar disc subquadrate, usually flat, sloping down posterolaterally, very rarely with moderate median keel; posterior margin of axilla usually rounded, axillar depression usually large and deep, with dense fine pilosity; mesopleuron usually flat or slightly convex, sometimes with moderate declivity in area of oblique median line; sternaulus absent; dorsellum moderately to densely hairy, keels sometimes obscured by pilosity, very rarely median keel strongly projecting; metapleuron generally rugulose, hairy, anterior depressed part with denser pilosity, posterior convex part with sparser nonapressed pilosity; propodeum relatively short, median keel strongly developed, usually raised into subtriangular point, rarely produced into spine, plica well developed, area between plica and median keel usually glabrous and highly shining, area anterior to plical area and sides of propodeum hairy; posterior margin of propodeum rimlike, moderately to deeply arcuate; forewing relatively short and broad, foremargin with row of long semierect bristles, wing often slightly to distinctly infuscate, venation distinctly exceeding basal third of wing length, submarginal vein almost straight, moderately to distinctly remote from foremargin, marginal and stigmal veins subtriangular in shape, stigmal vein often well defined, basal vein not developed but pigmented transverse strip often present below marginal vein; hind wing always with pigmented submarginal vein; wings sometimes strongly reduced in both sexes; legs moderately slender, femora and tibia clavate, tarsi not compressed, apex of anterior tibia at most with minute dorsal spine. METASOMA. Petiole robust, slightly to clearly elongate, often subquadrate, usually glabrous dorsally, with few strong longitudinal keels, rarely dorsally hairy, with abundant pilosity laterally and ventrally; metasoma past petiole slightly to distinctly elongate, only moderately convex dorsally, syntergite generally glabrous, sometimes with strip of fine pilosity anterolaterally; anterior margin of syntergite medially often raised, almost flexed, often moderately to distinctly excised medially; S2 anterolaterally with two hairy depressions, very rarely with large hairy cushion.

ReCOGNITION AND Relationships: Doliopria is closely related to Basalys mainly be- cause of the structure of the head, and the course of the submarginal vein in the forewing. Doliopria differs from Basalys principally in the structure of the female antenna as well as the absence of the basal vein in the forewing. Furthermore, the anterior margin of the syntergite is never excised or modified in Basalys. Doliopria reichenspergeri Ferrière was transferred to Szelenyiopria (Fabritius, 1974).

Distribution: Doliopria is restricted to the New World, with only a few species in the Nearctic region and with a high number of undescribed species in tropical America. The genus is not known in Chile.

BIOLOGY: Host unknown. Three Neotropical species were described associated with ants (Kieffer, 1910a, 1921; Ferrière, 1929); it is plausible to assume that they parasitize synoeketic Diptera because they show no specialized morphology. Ogloblin (1960) described several more Neotropical species with no data on hosts or habits.

\section{Ecitovagus Masner}

Figures 51, 52

Ecitovagus Masner, 1977: 33-36.

Diagnosis ( $q \hat{\sigma}$ ): Medium-sized individuals (approximately $3 \mathrm{~mm}$ ), with sexes very similar in general appearance in E. gibbus Masner; body light to dark ferrugineous, predominantly sculptured, rough rugulose and matte or partly sculptured and partly shining, metasoma past petiole predominantly smooth, sculpture of males generally finer; body generally with long semidecumbent bristles; foamy structures or hairy cushions not developed, but fine appressed pilosity may occur; antennal shelf margined posteriorly; frons armed; mesoscutum strongly humped anteromedially, hump compressed and highly elevated above head; mesosternum and metasternum anteriorly (in front of mid coxae) with deep cleft; posterior part of mid propodeum remarkably constricted, bellshaped, protruding backward above hind coxae, causing impression of 2-segmented petiole; tarsi distinctly compressed.

DESCRIPTION ( $q$ đ): HEAD. Head in dorsal view subquadrate, temple relatively long, head hypognathous, frons armed with three projections, antennal shelf sharply margined 
posteriorly, large and deep; head in lateral view with postgena behind eye distinctly wider than eye, eye relatively small, eye height distinctly shorter than half head height, ommatidia relatively large and convex; mandible bidentate lower tooth longer than upper tooth, palpi very short, palpal formula 3-2; oral carina strongly developed, gena and postgena almost glabrous; hypostomal bridge moderately developed; occipital flange narrow but distinctly steplike; female antenna 12-segmented, antennal clava nonabrupt, multisegmented ( 8 segments), clavomeres distinctly transverse, noncompact, A12 slightly reduced in size; A1 elongate, cylindrical, rounded apically, A3 remarkably elongate; male antenna 14-segmented, either with A3 and A4 strongly sexually modified, subtriangular, constricted basally and expanded distally, A5 to A13 strongly transverse, almost beadlike, A14 remarkably diminished, or A3 and A4 not sexually modified, A3 to A13 elongate, constricted basally, with scattered short bristles, A14 not diminished. MESOSOMA. Mesosoma moderately higher than wide; pronotal shoulders and epomium not developed; propleuron and anterior sides of pronotum without foamy structures or cushions of hairs, cervix of prothorax relatively short, pronotum strongly narrowed anteromedially; mesoscutum strongly humped anteromedially, hump compressed and highly elevated above head; tegula large, sculptured or smooth; scutellum trapezoidal, anterior scutellar pit transverse, subrectangular, large and deep, slightly shorter than scutellar disc; outer margin of axilla produced in sharp bladelike keel; scutellar disc pillow-shaped, convex, with moderate to strong median longitudinal keel, lateral keels not projecting; axillar depression deep; mesopleuron flat, subrectangular, straight ventrally, with deep oblique submedian sulcus; dorsellum usually well defined, with three longitudinal keels; metapleuron large, rugulose, with deep, large excavation anterodorsally, metapleuron separated dorsally from propodeum by sharp arched carina; median part of propodeum in dorsal view elongate, subcampanulate, protruding backward above hind coxa, laterally (near spiracle) with deep depression running obliquely from posterior margin of dorsellum to base of hind coxa, here forming deep cleft, thus causing impression of 2-segmented petiole, dorsal side of propodeum in lateral view not sloping, horizontal, median keel and plica not developed, posterior margin of propodeum deeply excavate; wings primarily developed, slender, slightly yellowish, marginal vein subtriangular, stigmal vein not developed; legs remarkably long and slender, femur in lateral view subcylindrical, nonclavate; hind tibia in dorsal view compressed in anterior half; tarsi distinctly compressed, especially on fore and middle legs. METASOMA. Petiole in dorsal view slightly to moderately elongate, robust, without longitudinal keels, with scattered bristles, in lateral view sometimes with sharp longitudinal keel ventrally, posterior side of petiole sloping abruptly down forming deep cleft with anterior margin of syntergite; metasoma past petiole in lateral view only slightly convex dorsally, entire syntergite with scattered semierect bristles, sometimes syntergite partly with fine coriaceous microsculpture; anterior margin of S2 entire; special spot on S2 large, near anterior margin.

RECOGNITION AND Relationships: Among the ecitophilic genera Ecitovagus can be distinguished conveniently on two apomorphic character states: the anteromedian hump on mesoscutum and the strongly constricted and prolonged median part of propodeum. Masner (1977) compared Ecitovagus with Myrmecopria, emphasizing differences in structure of mesoscutum, propodeum, and absence of sharp apices of tibiae in Ecitovagus. Ecitovagus shares some character states with Apopria, and also resembles Notoxoides and Philolestoides, primarily in the shape of the mesosoma, which is higher than wide and also in the profile of petiole and the rest of metasoma.

DistribUTION: We examined Ecitovagus gibbus (from Arizona), two species from Mexico, and one species from Costa Rica (CNCI); differences between these species indicate much larger extent of the genus in this region.

BIOLOGY: Ecitovagus gibbus is associated with Neivamyrmex nigrescens (Cresson) in Arizona; dealated female individuals were observed in raid columns of ants during crepuscular and night time observations. The wasps resemble ants, not only in size and 
color but also in movements, making distinguishing difficult. True lytic alectomy occurs in E. gibbus.

\section{Eladio, new genus}

Figures 45, 46, 47

Diagnosis ( $q$ đ): Medium-sized individuals ( 2 to $3 \mathrm{~mm}$ ), sexes considerably dissimilar; body predominantly light-colored, from yellowish brown to dark brown or ferrugineous; body almost entirely sculptured, usually head and mesosoma coarse, netlike, coriaceous or rarely body only matte, metasoma past petiole densely matte with fine microsculpture, in males sculpture generally finer to partly smooth, body predominantly hairy, hairs normal, thickened or specialized as flattened setae, whitish, golden, or rufous color; cushion of hairs well developed, foamy structures usually rudimentary, especially in females; female clava usually spindle-shaped, with subcompact clavomeres, male antenna apparently 13-segmented due to partial fusion of A3 and A4; female A12 not larger than $\mathrm{A} 11$; propodeum relatively large, median keel remarkably produced anteriorly into process curved backward, process often flattened dorsally, sometimes spatulate, reaching to or overlapping posterior margin of propodeum, plica well developed; metapleuron in females partly glabrous with sculpture similar to rest of mesosoma; wings relatively broad, surface distinctly glassy, often bronze; hind tibia with remarkable brush of long, dense, setae; metasoma past petiole relatively flattened dorsally.

DESCRIPTION ( $q$ o $)$ : HEAD. Head in dorsal view subglobular to moderately elongate anteriorly; frons unarmed; antennal shelf shallow, not margined posteriorly; head in lateral view with torulus in upper half of eye; eye oval, in female subequal to postgena, in males eye clearly longer than postgena; posterior orbit straight; ommatidia rather large and convex; oral carina moderately to well developed; postgenal cushion absent or minute; occipital flange weakly developed; head in frontal view with mandible bidentate, lower tooth longer; head in ventral view with hypostomal bridge moderately developed; palpal formula 5-2; female antenna 12 -segmented, with nonabrupt 5- or 7-segmented spindle-shaped clava, with subcompact clavomeres, A12 not larger than A11, A3-A5 distinctly elongate, cylindrical; A1 remarkably long and strong, cylindrical, unarmed apically; male antenna apparently $13-\mathrm{seg}$ mented due to partial fusion of A3 and A4; fused A3 and A4 sometimes with sharp carina on outer side; A5-A14 knotted with one whorl of bristles on each node; A7-A12 without specialized brushes, A1 elongate, cylindrical, shorter than in female, unarmed apically. MESOSOMA. Mesosoma in dorsal view with pronotum moderately developed, pronotal shoulders not developed; sides of pronotum without epomium, with moderate to well developed cushion of specialized hairs and some foamy structures; propleuron with foamy structures; mesoscutum as long as wide, moderately to distinctly convex; parapsidal and anterior parallel lines usually present; tegula sculptured, especially in females; anterior scutellar pit shallow, small, smaller than axilla or scutellar disc; scutellar disc subcircular, moderately convex, with moderate longitudinal keel, rarely crested and then almost pyramidal, lateral keels of scutellar disc moderately developed; axilla remarkably large, posterior margin sharp, axillar depression small but deeply excavate, with rudimentary foamy structures; mesopleuron almost flat, median oblique line weakly developed; dorsellum well developed, with sharp keels, metanotum laterad dorsellum smooth and shining; metapleuron in females partly glabrous with sculpture similar to rest of mesosoma, metapleuron in males covered with dense pilosity; propodeum relatively large, median keel remarkably produced anteriorly into process curved backward, process often flattened dorsally, sometimes spatulate, reaching to or overlapping posterior margin of propodeum, plica well developed; posterior margin of propodeum sharp, deeply concave, posterolateral corners of propodeum produced and pointed; wings relatively broad, surface distinctly glassy, often bronze; basal part of front margin and submarginal vein distinctly upcurved, stigmal vein relatively well developed; legs relatively strong, entirely sculptured, femur rather thick, nonclavate, hind tibia with remarkable brush of short dense setae; apex of foretibia without specialized dorsal spine. 
METASOMA. Petiole subquadrate to slightly elongate in females, distinctly elongate in males, cylindrical, with abundant pilosity, in males with foamy structures; metasoma past petiole relatively flattened dorsally, only moderately convex ventrally, females with short broad apical point; S2 without specialized spot; anterior margin of syntergite distinctly wider than petiole.

TYPE SPECIES: Eladio cruzi, new species (described below), by present designation.

RECOGNITION AND RELATIONSHIPS: Members of Eladio can be recognized conveniently on two synapomorphies, namely the characteristic netlike reticulation of the head, mesosoma, and legs, and the dense brush of setae on inner side of tibia. Eladio is also characterized by glassy wings, a strongly developed median keel of propodeum as well as high degree of thick pilosity on pronotum, metapleuron, and petiole. Eladio appears related to Acanthopria primarily because of structure and shape of wings and type of male antenna, especially the fusion of A3 and A4. Eladio is also related to Szelenyiopria, another derivative of Acanthopria.

ETYMOLOGY: The generic name is dedicated to Mr. Eladio Cruz, one-time resident of Peñas Blancas (Costa Rica). Mr. Cruz helped to operate Malaise traps on his property where three species of Eladio were discovered; the gender is neuter.

DiSTRIBUTION: At present, we recognize six species of Eladio (including E. cruzi, new species, described below) from lowland rainforests in Costa Rica and Panama (CNCI, MIZA).

BIOLOGY: The host is unknown. However, judging from sculpture, pilosity and color of body we assume that members of Eladio are associated with ants. However, wing alectomy or occurrence of members in light trap was not observed.

\section{Eladio cruzi, new species}

Figures 45, 46, 47

DESCRIPTION: Holotype, $q$ : Length 2.2 $\mathrm{mm}$; body entirely ferrugineous brown, metasoma past petiole darkest, legs, A1 to A7 and palpi yellowish brown, without flattened appressed whitish setae wings parchmentlike, with lighter transverse band below stigmal vein; head, mesosoma, legs and A1 entirely netlike reticulate, reticulations finer on tibia and tarsi, propleuron partly smooth, propodeum between plicae partly smooth, metasoma past petiole with fine dense punctures; body (including appendages) with scattered decumbent yellowish setae. HEAD. Head in dorsal view as long as wide (46:46), narrower than mesosoma (46:55), frons in front of eye shorter than temple behind eye (12:15), eye as long as temple (15:15), posterior ocelli outside ocular zone; head in lateral view slightly higher than long (50:46), eye as long as postgena (15:15); postgenal cushion not developed; A1 to A7 without flattened appressed whitish setae; antennomeres in relative proportions (51:10), (10:7), (33:5.5), (15:5.5), (13:6), (12:6.5), (11:7.5), (12:9), (12:11), (12:11.5), (15:11.5), (15:10). MESOSOMA. Mesosoma in relative proportions length:width:height (90:55:65); pronotum with minute cushion of yellowish hairs, propleuron with strip of foamy structures in upper half; mesoscutum length:width (38:40), anterior parallel lines rather long, weakly defined, parapsidal lines developed as narrow zone without sculpture; scutellar pit subtriangular, with tip pointed up; scutellar disc only moderately convex, median keel complete; mesopleuron with strong netlike reticulation similar to that on head and rest of mesosoma; dorsellum well developed; sculpture of metapleuron appears more rugulose than reticulation of mesopleuron; spatula of propodeal keel relatively narrow, in lateral view, tip of spatula not exceeding posterior margin of propodeum at meson, area between plica and median keel (below spatula) partly smooth, dorsum of posterolateral corners smooth; femora and tibia without appressed whitish setae. METASOMA. Petiole in relative proportions length/width (15:16), dorsally with longitudinal irregular keels; metasoma past petiole in relative proportions length/width/ height (80:52:36); syntergite with denser pilosity in lateral parts and generally in posterior third; following tergites equally hairy, S2 and following sternite with same pilosity as in dorsal side.

MaLE: Allotype. Differs from female principally in following character states: body generally darker and sculpture finer; body with only fine nonspecialized hairs; foamy 
structures better developed on pronotum, propleuron and side of petiole; eye much larger than in female, distinctly longer than postgena (20:9), genal cushion replaced by small hairy spot; A3 and A4 with low carina on outer side; petiole clearly elongate, length:width (19:14); metasoma past petiole more elongate, relative proportions length: width:height (82:48:35); syntergite with finer sculpture and same pattern of pilosity as in female.

TyPe Material: $23 q, 3 \pi$. Holotype, $q$ (CNCI no. 22453), COSTA RICA, Alajuela, Peñas Blancas, September-October 1987, $700 \mathrm{~m}$, primary rainforest, MT, E. Cruz. Paratypes, $4+$, with same data as holotype; 19 , October 1986; 1 ㅇ same locality, July 7, 1987; 2 , December 1987; 4우, October 1987; 1 ㅇ, January 1-10, 1987; 3 , February 1987; 3 , May 1987; 1 \%, March 1987; 1 , Heredia, Pto. Viejo, February 1980, 50 m, rainforest, W.R.M. Mason; 19 , Puntarenas, Monteverde, August 1987, 1600 m, MT, D.M. Wood. Allotype, ô (CNCI), same data as holotype, June 9, 1987; $10^{\star}$ February 1987; $10^{\top}$, B. Carrillo N.P. $84^{\circ} 07^{\prime} \mathrm{W}, 10^{\circ} 10^{\prime} \mathrm{N}$, April 10, 1985, $500 \mathrm{~m}, \mathrm{H}$. Goulet and L. Masner.

ETYMology: The species is named in honor of Mr. Eladio Cruz, formerly of Peñas Blancas (Costa Rica).

Distribution: Costa Rica.

BIOLOGY: Unknown.

VARIATION: The series of 21 females from Peñas Blancas (Costa Rica) is morphologically very cohesive; single female from La Selva (Costa Rica) is slightly smaller and lighter, with spatula of the median keel wider.

\section{Hansona, new genus}

Figure 57

DiAgnosis ( $q$ o $\widehat{o}$ ): Medium-sized (around 2 $\mathrm{mm}$ ) individuals; body predominantly reddish brown to yellowish brown, legs and antennae lighter, body partly to predominantly matte, with intense granular, reticulate, or coriaceous sculpture, with dense pilosity, sometimes with short flattened appressed setae, foamy structures absent; female antenna 11segmented, gradually incrassate toward apex, with massive 1-segmented clava (A11), clavomeres not flattened ventrally; A11 without ventral pit; male antenna 14-segmented, with dense nonwhorled pilosity, A4 not modified; head broadly subpentagonal, eyes remarkably large, strongly prominent, with raspberry-like ommatidia; ocelli large; anterior scutellar pit very large but shallow; plica of propodeum often strongly raised, arcuate, and pointed posteriorly.

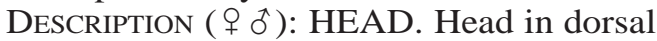
view broadly subpentagonal, wider than long; frons unarmed; antennal shelf well developed in front of toruli; female temple behind eye almost straight, strongly receding, male temple very short, rounded and receding; head in lateral view subglobose, antennal shelf moderately projecting; level of torulus at midpoint of eye; eye large, ovoid, distinctly higher than long, with large raspberry-like ommatidia; ocelli large; oral carina moderate, partly obscured by pilosity; postgena with distinct hairy cushion; occipital flange rudimentary, not steplike, not crenulate; head in frontal view wider than high, clypeus almost flat, epistomal sulcus not developed; labrum not exposed; tentorial pit not developed; mandible relatively small, bidentate, clasped; malar sulcus not developed; palpi short, palpal formula 4-2; hypostomal bridge moderately developed; female antenna 11-segmented, A1 long cylindrical, apical rim not excavate ventrally, rim not produced into flaps; clava nonabrupt, gradually incrassate toward apex, A11 forming massive 1-segmented clava, clavomeres not flattened ventrally, A11 without ventral pit. MESOSOMA. Mesosoma relatively short, about as wide as high, considerably flattened dorsally; prothorax in dorsal view with cervix well developed; pronotal shoulders not prominent; pronotum dorsally (behind cervix) and along anterior margin with hairy cushions or dense pilosity, side of pronotum almost flat, smooth, mostly glabrous; epomium not developed; propleuron in upper part with hairy cushion or dense pilosity; mesoscutum almost semicircular, glabrous or with scattered semierect hairs; parapsidal and anterior parallel lines absent; humeral and posthumeral sulci not developed; anterior scutellar pit large, transverse, shallow; scutellar disc flat, or only moderately convex, pillow-shaped, with weak lateral keels; axillar lateral and posterior scutellar 
pits not developed; posterior margin of axilla rounded, axillar depression very small; mesopleuron only slightly convex, smooth shining and glabrous, median oblique depression not developed; sternaulus not developed; posterior margin of mesopleuron smooth, noncrenulate; metanotum relatively narrow; dorsellum with three longitudinal keels; metapleuron densely hairy; propodeum relatively large; median keel distinctly cresting anteriorly; area between plica and median keel perfectly glabrous; plica of propodeum strongly raised, arcuate and sharply pointed posteriorly, area laterad of plica with dense strong pilosity; side of propodeum densely hairy; nucha moderately long; forewing relatively short, in female slightly surpassing tip of metasoma, longer in males, marginal cilia moderately long; submarginal vein considerably upcurved, strongly approximated to foremargin of wing; marginal vein moderately elongate, reaching basal third of wing length, stigmal vein short, no other veins developed; hind wing with submarginal vein indicated only near hamuli; legs relatively short and stubbed; apex of foretibia dorsally without specialized spine but only with minute point; hind tibia attenuate in basal twothirds, moderately clavate in posterior third. METASOMA. Metasoma short, pedunculate; petiole elongate, cylindrical, with several longitudinal carinae, densely covered with long dense pilosity; metasoma past petiole short, slightly longer than wide, sharply pointed apically in female, with apical tergites yellow; anterior margin of syntergite as narrow as petiole, not notched medially; anterior margin of S2 broad, remote from base of petiole, in female with distinct basal gland internally; apical sternite in female sharply triangular, subvomeriform.

TyPE SPeCIES: Hansona pauli, new species (described below), by present designation.

RECOGNITION AND RELATIONSHIPS: Hansona appears related to a group of species in Leucopria with which it shares general habitus, structure of female antenna, and leucose-yellow glandular spot on apex of metasoma in females. It differs from Leucopria by round-shaped scutellum, strongly sculptured mesoscutum, in male by nonverticillate A3-A13. In the key, Hansona comes in the same couplet with Xanthopria; the two gen- era are only distantly related and differ principally by the absence (Xanthopria) or presence (Hansona) of marginal cilia in the forewing.

ETYMology: The generic name is dedicated to Dr. Paul Hanson (Universidad de Costa Rica) for his valuable help over many years; the gender is feminine.

DISTRIBUTION: At present, several species are known to us from the lowland rainforests in Central America (Costa Rica, Panama), Trinidad, and South America (Brazil, Ecuador, Venezuela).

BIOLOGY: Host is unknown, however, the structure of eyes, size of ocelli, the microsculpture and color of the body together with the presence of a distinct gland at the base of S2 indicate possible association with ants and nocturnal habits. Several specimens were caught in light traps.

\section{Hansona pauli, new species}

Figure 57

DESCRIPTION: Holotype, $q$ : Length $2 \mathrm{~mm}$; body generally chestnut brown, head and metasoma darker, propodeum, and petiole light brown, tegulae, legs, and antennae yellowish brown; forewing almost clear, with longitudinal nebulous streak in course of $M$ vein. HEAD. Head in dorsal view broadly subpentagonal, distinctly wider than long (51:40); ocelli in close isosceles triangle, POL equals LOL, OOL considerably larger than POL (14:3); temple as long as eye (15: $15)$, straight, strongly receding; head in lateral view only slightly higher than long (42: 40); eye distinctly higher than long (25:17), as long as postgena (17:17), eye height only slightly larger than malar space (17:15); head in frontal view with eye strongly bulging and cheek strongly converging, face entirely rugulose; antennal segments in relative proportions (32:8.5), (9.5:7.5), (10:6.5), (7:6.5), (7: 6.5), (7:7), (7:7), (7:9), (6:10.5), (6:11), (21: 14.5). MESOSOMA. Mesosoma in dorsal view longer than wide (85:58); mesoscutum slightly wider than long (46:31); anterior scutellar pit only slightly shorter than scutellar disc medially; propodeum laterad plica and petiole with long strong yellowish hairs; incrassate part of all femora distinctly flattened ventrally; inner side of hind tibia with 
single row of very long erect hairs; middle and hind basitarsi distinctly elongate, subequal to or longer than tarsomere 5. METASOMA. Petiole twice as long as wide (20: $10)$, with moderate flange anteriorly; syntergite slightly longer than wide (62:53), with scattered semidecumbent pilosity laterally and posteriorly, S2 smooth, medially with two ovoid patches of dense punctures.

MALE: Unknown. We examined 14 males from Panama (Barro Colorado, light trap), and 10 from Ecuador (Pichincha) that may be the opposite sex to the holotype. The males differ from the female principally by much larger eyes and smaller, rounded temples.

TyPe MATERial: $6 q$. Holotype, $q$ (CNCI no. 22456), COSTA RICA, Limon, $16 \mathrm{~km}$ W Guapiles, $400 \mathrm{~m}$, October-November 1989, P. Hanson, MT. Paratypes, 19 , COSTA RICA, Puntarenas, R.F. Golfo Dulce, 24 km W Piedras Blancas, $200 \mathrm{~m}$, February 1992, P. Hanson, MT; 3 , PANAMA, Barro Colorado Is., Canal Zone, April 9 and 16, 1980, Henk Wolda (light trap); 19 Fort Clayton, Canal Zone, August 25, 1981, R.B. Kimsey (light trap).

ETYMOLOGY: The species is dedicated to Dr. Paul Hanson (Universidad de Costa Rica), who collected the holotype specimen of the type species.

Distribution: Costa Rica, Panama.

BIOLOGY: Unknown; all specimens were collected in lowland rainforest.

VARIATION: No variation encountered in females comprising the type series.

\section{Labidopria Wasmann Figure 58}

Labidopria Wasmann, 1925: 194.

DiAgnosis ( $q$ ): Small to medium-sized individuals (1 to $2.5 \mathrm{~mm}$ ); head, mesosoma, and metasoma subglobular, mesosoma highly convex, metasoma dorsally strongly convex; two distinct constrictions occur on body, one in cervical region between head and mesosoma, and another between propodeum and metasoma past petiole; body predominantly light-brown-colored, rarely yellow, body mostly smooth and shining, in some species entirely matte with coarse sculpture; body including entire metasoma hairy, usually with two types of pilosity, fine, dense and appressed hairs and sparse semierect long bristles; foamy structures at most reduced to metasternum, rarely rudimentary on upper propleuron, heavy hairy cushions very rarely developed; hypostomal bridge unusually wide; occipital flange remarkably wide around entire circumference, collarlike; cervix of prothorax distinctly elongate, never with foamy structures or heavy cushions; axillar depression rudimentary; mesopleuron remarkably convex; posterior margin of propodeum dorsally deeply excavate, nucha of propodeum often flanked dorsally and laterally by sharp, semitransparent lamina overlapping anterior border of petiole; hind femur usually moderately to strongly compressed and curved basally (dorsal view); petiole without longitudinal keels, with no foamy structures; syntergite highly convex, entirely hairy, with anterior margin overlapping posterior border of petiole.

DESCRIPTION ( $q$ ): HEAD. Head perfectly globular, rarely subpentagonal, hypognathous, with frons unarmed, antennal shelf moderate; face in lateral view convex; eye usually normal, sometimes large with large and convex ommatidia, posterior orbit straight or sinuate; malar sulcus not developed; mandible subequal and bidentate; papal formula 43 or $3-2$, rarely $5-2$; oral carina usually absent, rarely moderately developed; upper postgena rarely sharply angular; postgenal cushion not developed, postgena at most with scattered pilosity; hypostomal bridge unusually wide; occipital flange remarkably wide around entire circumference, collarlike; female antenna 12-segmented, generally with nonabrupt clava, with six to eight clavomeres, clavomeres rectangular or quadrate, with distinct gaps, clava rarely abrupt, with five to six segments, A1 usually compressed in basal half, A12 not enlarged. MESOSOMA. Mesosoma relatively short, subglobular, highly convex, both dorsally and ventrally, pronotum with long cervix, sides of pronotum strongly convex, generally densely hairy, rarely with only scattered bristles, in some species with coriaceous or rugulose sculpture, without epomium, never with foamy structures or heavy cushions; pronotal shoulders generally absent, if developed, pointlike and anterior margin of pronotum 
rarely with heavy collar of pegs; mesoscutum semicircular, strongly convex dorsally; anterior scutellar pit very shallow to almost rudimentary, or indicated as shallow depression; axillar depression rudimentary, usually without foamy structures; posterior margin of axilla as well as sides of scutellar disc sloping down roundly; scutellar disc only slightly convex, lateral and medial keels indistinct or absent, rarely disc balllike convex; mesopleuron usually remarkably convex, rarely only moderately convex, partly hairy; median oblique line well developed, rarely even sulcate; sternaulus absent; dorsellum with three keels only rudimentary or keels absent; propodeum smooth, coriaceous or rugulose, rather short, rounded to conical, median keel absent or at most indicated only anteriorly, posterior margin of propodeum dorsally deeply excavate, margin dorsally and laterally produced into sharp semitransparent lamina, very rarely lamina dorsally absent, laminae often overlapping anterior border of petiole; wings primarily developed, almost clear, remarkably long, submarginal vein relatively short, submarginal vein moderately curved up toward marginal vein and running strongly approximated to anterior margin of wing, stigmal vein relatively well developed; legs very long and strong, sometimes even incrassate, coxa, especially hind, very large and densely hairy; hind femur moderately to strongly compressed and curved basally (dorsal view); hind tibia compressed basally; tarsi moderately to strongly compressed. METASOMA. Petiole elongate, without longitudinal keels, finely sculptured, densely pubescent, with short hairs and scattered long bristles, with no foamy structures, often conical, wider anteriorly and tapering posteriorly, sometimes compressed posteriorly, in some species with transverse globular knot; metasoma past petiole usually globular, highly convex dorsally, rarely only moderately convex and slightly elongate, anterior margin of syntergite in lateral view generally distinctly overlapping posterior border of petiole, entire syntergite hairy, with long sparse bristles or dense decumbent hairs; S2 with dense pilosity, anteriorly without specialized spot; apex of metasoma with only small point.

ReCognition and Relationships: Among related genera of Diapriini, members of $\mathrm{La}$ bidopria can be distinguished by the followings character states: body strongly constricted in cervical and petiolar regions, with head mesosoma and metasoma past petiole strongly globular; posterior margin of propodeum usually with semitransparent laminae; petiole without longitudinal keels; syntergite entirely hairy. Unlike in Acanthopria, foamy structures are rudimentary or absent in Labidopria. Mimopriella differs from Labidopria principally in formation and shape of propodeum. Corresponding males could not be associated with females in species studied by us; this could be explained by males undistinguished generally from, e.g., Acanthopria, or males being very rare, or all Labidopria species being parthenogenetic.

Distribution: This genus is known to us from lowland tropical forests of South and Central America, with species extending to Mexico and one to USA (South Arizona). No individuals were examined from the Antilles. Only 3 species were described so far, but we examined and recognized some 20 species (CNCI).

MALE: Unknown (see note in Recognition and Relationships).

BIOLOGY: The published data indicate close association with the ecitonine ant genus Labidus (Ferrière, 1929; Borgmeier, 1939; Loiácono, 1981); unpublished data in CNCI also confirm association with genus Labidus, especially $L$. predator (Smith). Character states typifying Labidopria in our opinion reflect high degree of adaptive morphology for life with ants, such as strongly developed legs, compressed base of femora, compressed tarsi, etc. Numerous specimens examined by us were collected by light trap (CDC light trap) in Brazil. Many females in the collection are wingless or have little wing stumps. We are considering true lytic alectomy for species with no rudiments; the presence of wing stumps may be explained by the spontaneous breaking of wing in basal area or by cutting off the wings by the host ants.

Leucopria, new genus Figure 61

Diagnosis ( $q$ ๑): Medium to large-size individuals (2 to $3.5 \mathrm{~mm}$ ); body in most spe- 
cies light brown, rarely yellowish or dark brown, smooth and shining, very rarely with coriaceous or rugulose sculpture; body generally with heavy pale dense semierect hairs, mesopleuron partly hairy, legs densely hairy, apex of syntergite and following tergites and all sternites, especially on apical sternite, densely hairy with dense decumbent pilosity; foamy structures present on propleuron, metasternum, axillar depression, and often on pronotum and petiole; anterior scutellar pit large, deep, subequal in length to scutellar disc; scutellar disc boxlike, sharply subquadrate, unarmed dorsally, sides of disc with sharply carinate rim, rim often crenulate inward; axillar depression large, deeply excavate, posterior margin of axilla sharp bladelike; median propodeal keel strongly produced, fingerlike bent, obtuse apically, usually directed obliquely backward; apex of metasoma in female sharply pointed or almost conical, with several apical tergites contrastingly whitish-yellow and densely hairy; S2 anteriorly with distinctly specialized spot; apical sternite sharply triangular, with dense pale pilosity.

DESCRIPTION ( $\left.\begin{array}{c}q \\ o\end{array}\right)$ : HEAD. Head globular, hypognathous, with frons unarmed; antennal shelf moderate; torulus located in middle or upper middle of eye; face quadrate or elongate, distinctly hairy; eye relatively large, eye height larger than half of head height or subequal to half of head height, eye ovoid, higher than wide, posterior orbit rounded or sometimes slightly sinuate, ommatidia often large and convex; malar sulcus never developed; mandible bidentate, sometimes unequal, with right mandible subtridentate and left mandible bidentate; hypostomal bridge very narrow; palpal formula 5-2; oral carina strongly developed, very rarely absent; postgenal cushion rarely developed, postgena usually with long dense hairs; gena in frontal view often projecting angularly; occipital flange usually narrow, moderately developed, not steplike; female antenna either 11- or 12segmented, clava nonabrupt, multisegmented (6-segmented) or clava nondistinctly developed; A1 often strongly elongate, cylindrical and rounded apically, antennomeres elongate rectangular, cylindrical and subcompact; male antenna 14-segmented, with A4 not distinctly sexually modified, antennomeres elongate, more or less cylindrical, sometimes slightly constricted medially, with two slight knots and bristles of long erect hairs more or less arranged in whorls, or antennomeres subrectangular with hairs scattered randomly. MESOSOMA. Mesosoma about as high as wide; pronotal shoulders not developed but sides of pronotum moderately convex; epomium absent, foamy structures always on propleuron and often on anterior sides of pronotum; mesoscutum usually semicircular and highly convex in lateral view, very rarely with parapsidal keels or sulci; scutellum distinctly trapezoidal, anterior scutellar pit always present, large, deep, subequal in length to disc, quadrate or transversely subrectangular; scutellar disc usually boxlike, sharply subquadrate, unarmed dorsally, median keel usually not developed, very rarely rudimentary, disc in one species highly convex and with rugulose sculpture, sides of disc with sharply carinate rims, rims often crenulate inwardly; axillar depression large, deeply excavate, always with abundant foamy structures; posterior margin of axilla sharp, bladelike; mesopleuron moderately convex, higher than wide, lower anterior half often with sparse long hairs; metapleuron and sides of propodeum with scattered long semierect hairs, with coarse sculpture well visible; propodeum relatively long, median propodeal keel always strongly produced anteriorly, bent fingerlike, obtuse apically, usually directed backward, plica distinctly developed; wings always present, normal size, hyaline, very rarely bronze infuscate; submarginal vein moderately to distinctly curved up toward marginal vein and running strongly approximated to anterior margin of wing; stigmal vein relatively well developed; basal vein not developed; legs relatively slender, rarely incrassate, apices of femora often with flaps, tarsi moderately to strongly compressed laterally; apex of foretibia without specialized spine dorsally. METASOMA. Metasoma widely overlapped by wings; petiole always elongate, often very slender, cylindrical, with longitudinal keels, with long scattered hairs and always with foamy structures; metasoma past petiole moderately elongate, in dorsal view broadly spindlelike, in lateral view only slightly convex or almost flat dorsally, strongly convex ventrally; pos- 
terior part of syntergite and subsequent tergites with rows of dense semierect yellowish hairs; apex of metasoma in female sharply pointed or almost conical, with several apical tergites contrasty whitish-yellow and densely hairy; S2 anteriorly with distinct specialized spot, spot sometimes rudimentary in males; female apical sternite sharply triangular with dense pale pilosity.

TYPE SPECIES: Leucopria cylindricornis, new species (described below), by present designation.

RECOGNITION AND Relationships: Females of Leucopria share large whitish-yellow spot on apex of metasoma, with those of Hansona; this structure is interpreted here as an internal gland with appeasement or repugnatory function. Leucopria can be easily distinguished from Hansona by structure of scutellum, by presence of foamy structures on propleuron and in axillar depression, as well as by smooth mesoscutum. We basically recognize two species groups within Leucopria: one with female antenna with slender clava and the other with female antenna strong, gradually incrassate toward apex. The males of Leucopria also represent two distinct species groups: one with characteristic doublewhorled antennomeres and other with antennomeres with only scattered erect hairs. Leucopria appears close to Acanthopria, from which it can be distinguished principally by the different structure of scutellum (anterior pit, sides of scutellar disc), furthermore by the presence of a specialized spot on S2, and especially by whitish-yellow apex of female metasoma. In the male sex Leucopria differs from Acanthopria principally by the arrangement of bristles on antennomeres. Finally, members of Leucopria are generally more pubescent that those of Acanthopria, especially on ventral side of metasoma.

ETYMOLOGY: The Latin prefix leuco refers to whitish (leucose)-yellow apex of female metasoma, the place of the presumed gland, the word pria meaning "little wasp"; the gender is feminine.

DisTRIBUTION: This new genus appears to be centered in lowland tropical rainforests of Central and South America (including Mexico), with no members recorded from the Antilles. We examined a single female specimen from Southern California (CNCI). At present we recognize some 30 species in the material studied (CNCI).

BIOLOGY: The hosts are unknown; some special morphological adaptations in the female sex (special spot on S2, whitish-yellow apex of female metasoma, pale dense pilosity of body, etc.) indicate possible association with various groups of ants. Two documented cases (CNCI) support the view; one species was found deep in the nest (fungus garden) of Apterostigma auriculatum Wheeler (Attini) in Costa Rica. Also in Costa Rica a series of an undescribed species of Leucopria was observed flying close above a raiding column of Eciton burcheli (Westwood) (Ecitonini). Species of Leucopria are probably nocturnal, especially in dispersal habits, as documented by numerous individuals of both sexes caught in light traps in lowland rainforests of Panama and Brazil. Allectomy was not observed among individuals caught in light traps.

\section{Leucopria cylindricornis, new species} Figure 61

DESCRIPTION: Holotype, $q$ : Length 3.5 $\mathrm{mm}$; body light brown, legs uniformly lighter, wings clear, with pale yellowish tint especially in proximal half. HEAD: Head in dorsal view as long as wide (58:58), generally with long scattered hairs; temple behind eye slightly wider than length of eye (24:22); occipital flange wide, as wide as width of ocellus; head in lateral view slightly higher than long (64:58), vertex highly topped; eye distinctly higher than long $(35: 22)$, posterior orbit almost straight; malar space distinctly shorter than eye height (10:35); postgena without cushion but with dense long semierect hairs, oral carina strongly developed; cheek sharply angular, almost pointlike; lower margin of clypeus distinctly flexed; antenna slightly longer than entire body, all segments distinctly elongate, cylindrical, clava indistinctly 6-segmented, clavomeres subcompact, antennomeres in relative proportions (90:11), (14:9.5), (13.5:9), (28:9.5), (26:10), (24:10.5), (24:11.5), (24:12), (20: 12), (20:13) (19:13), (26:12); A1 with long scattered hairs and fine dense granular microsculpture; A2 to A6 with median long scattered hairs and microsculpture similar to 
A1; A6 to A12 with dense short pilosity and special appressed whitish setae. MESOSOMA. Mesosoma in proportions length:width: height (121:73:82); upper anterior corner of pronotum (below cervix) with distinct patch of foamy structures, adjacent to similar patch of foamy structures on upper propleuron; median lobe of mesoscutum highly convex; anterior scutellar pit as long as wide, distinctly shorter than scutellar disc (15:20); scutellar disc with lateral rims sharp, distinctly crenulate inwardly, sides of disc distinctly divergent posteriorly, scutellar disc only slighter convex, without keel; axillar depression well developed, with abundant foamy structures; mesopleuron in lower half with scattered semierect hairs, few scattered hairs on both sides of suture between pronotum and mesopleuron; median propodeal keel strongly fingerlike, facing backward, propodeal plica sharply defined, enclosing two elongate fields on propodeal dorsum, propodeum in lateral view relatively long, only gradually sloping toward posterior margin; legs long and slender, femora progressively incrassated; tarsi generally compressed, hind basitarsus higher than wide (8.5:5); hind tarsomere 5 twice as high as wide (6:3). METASOMA. Metasoma with petiole cylindrical, strongly elongate (50:17), with several strong longitudinal keels, with two patches of foamy structures at sides posteromedially and with scattered long semierect pale hairs; metasoma past petiole broadly spindlelike, longer than wide (125:67); syntergite predominantly glabrous and smooth, in posterior third with scattered pale hairs; whitish-yellow spot occupying apical two tergites; spot on S2 large, as long as width of petiole; S2 with long semierect hairs in median part, arranged in two longitudinal rows.

MALE: Unknown; we examined several males from the type localities but we cannot associate the sexes properly.

TyPe MATERIAL: $16 q$. Holotype, $q$ (CNCI no. 22457), ECUADOR, Pichincha, Santo Domingo, $47 \mathrm{~km} \mathrm{~S}$ Rio Palenque, $200 \mathrm{~m}$, May 18-30, 1975, S.B. Peck, FIT. Paratypes, $3 \%$, same data as holotype; $3 q$, same data as holotype, but caught February 17-25, 1979, L. Ling; 1 \%, ECUADOR, Pichincha, 16 km SE Santo Domingo, Tinalandia, $680 \mathrm{~m}$, June 15-30, 1975, S. \& J. Peck, FIT; 19 , as above, but $500 \mathrm{~m}$, June 4-14, 1975; 1 운, PANAMA, Canal Zone, Barro Colorado Is., May 14-20, 1977, H. Wolda, light trap; 3 , Canal Zone, but caught May 10, and August 18, 1956, C.W. and M.E. Rettenmeyer; 1 \% , COSTA RICA, Puntarenas, road to Rincon, $24 \mathrm{~km} \mathrm{~W}$ of Pan Am Highway, FebruaryMarch 1989, 200 m, P. Hanson and I. Gauld; 19 , Heredia, Puerto Viejo, $50 \mathrm{~m}$, rainforest, February 1980, W. Mason; 19, Limon, 16 km W Guapiles, 400 m, January-March 1990, P. Hanson, MT.

ETYMOLOGY: The specific epithet refers to the distinctly elongate shape of female antenna.

Distribution: Ecuador, Panama, Costa Rica; the actual distribution is probably much wider.

Biology: Host unknown; several females caught in light trap.

VARIATION: Slight variation in body size exists in the type series.

\section{Megaplastopria Ashmead Figure 62}

Megaplastopria Ashmead, 1903: 31.

Xyalopria Kieffer, 1907: 300. NEW SYNONYMY.

Diagnosis ( 9 o $)$ : Medium to large-size individuals, $(2.5-5.5 \mathrm{~mm})$; body predominantly dark brown to black, rarely lighter, with lighter appendages, predominantly smooth and glabrous, with scattered long bristles, heavy hairy cushions and foamy structures; occiput usually with sharply pointed upright spine medially, spine usually bordered posteriorly by raised transverse edge making occipital flange steplike; A1 with remarkable longitudinal keels, especially ventrally, apical rim sharp, often spinelike on outer edge; female A12 often largest segment; male A3A14 strongly elongate, cylindrical, not knotted, with long, erect scattered bristles, always with distinct irregular sculpture, matte; male A1 relatively short, always distinctly shorter than A3; anterior scutellar pit moderately to strongly elongate, relatively deep, without longitudinal keel; anterior margin of S2 always with two hairy depressions.

DESCRIPTION ( + † $\precsim$ ): HEAD. Head in dorsal view globular, with antennal shelf strongly projecting, rather large, anterior margin of shelf bladelike, often angular medially; frons 
unarmed; antennal shelf large, bladelike projecting, not margined posteriorly; temple behind eye relatively short, receding; level of torulus in middle or upper half of eye; eye remarkably large, much larger than malar space, subcircular, only slightly higher than long, posterior orbit of eye straight; ommatidia relatively small, not convex; malar sulcus not developed, cheek rarely with shallow declivity; ocelli remarkably large; oral carina well developed; postgena with massive cushion consisting of foamy structures and dense hairs; occiput usually with sharply pointed upright spine medially, spine usually bordered posteriorly by raised transverse edge making occipital flange steplike, occipital flange well developed, rather broad; head in frontal view with face distinctly elongate; mandible bidentate, normally equidentate; anterior margin of clypeus moderately flexed; epistomal sulcus often well developed; tentorial pit present but shallow; hypostomal bridge present, narrow; palpi rather long and slender, palpal formula 5-2; female antenna 12-segmented, clava nonabrupt, clavomeres progressively incrassate toward apex, A12 often remarkably enlarged, distinctly higher than wide, often as long as two or three preceding antennomeres, ventral pit not developed, A1 with longitudinal keels, especially ventrally, keels rarely rudimentary, apical rim sharp, often spinelike on outer edge; male antenna 14-segmented, remarkably long and slender, A1 relatively short, A2 very small, spherical, A3 longest of all segments, A4 sexually modified with sexual carina, A3-A14 strongly elongate, cylindrical, not knotted, with long erect scattered bristles, always with distinct irregular sculpture, matte, with special brushes on $\mathrm{A} 7$ and $\mathrm{A} 8$ moderately developed. MESOSOMA. Pronotum in dorsal view relatively well developed, with shoulders prominent but obscured by heavy pronotal cushion; side of pronotum rather flat; epomium usually developed dorsally, with vertical part usually obscured by heavy pronotal cushion; pronotal cushion heavy, mixed with foamy structures; propleuron with extensive foamy structures, covered partly by dense pilosity or cushion; mesoscutum generally longer than wide, slightly convex; parapsidal and anterior parallel lines not developed; tegula remarkably large; anterior scutellar pit moderately to strongly elongate, relatively deep, without longitudinal keel, as long as scutellar disc, with anterior margin straight, and posterior margin subacute; scutellar disc subquadrate with median longitudinal keel more or less developed, lateral keels of disc sharp, area on disc between lateral keel and median keel often distinctly depressed, posterolateral corners of disc sharply rectangular; axilla rather large, broadly confluent with scutellar disc, with posterior margin sharp and oblique $\left(45^{\circ}\right)$; axillar depression relatively small but deep, with abundant foamy structures; mesopleuron rather flat, trapezoidal, wider ventrally than dorsally, oblique median line entirely absent; sternaulus rudimentary, indicated posteriorly above midcoxa; fore and middle coxa often connected by longitudinal groove; dorsellum well developed, lateral keels always well produced, median keel usually absent, rarely rudimentary; metapleuron predominantly with dense appressed silvery pilosity; metasternum with foamy structures; median keel of propodeum strongly produced anteriorly into long, slender spine pointed backward, spine often overlapping posterior margin of propodeum, area between plica and median keel relatively glabrous, sides of propodeum with dense, appressed, silvery pilosity; plica moderately developed; posterior margin of propodeum deeply V-shaped excavate; forewing often infuscate, venation reaching basal third of wing, submarginal vein almost straight, stigmal vein rudimentary, basal vein not developed; legs long and slender, trochanters remarkably elongate, femora and tibiae constricted basally, strongly clavate distally; posterior femur apically with flanges; apex of foretibia with moderate to rudimentary spine dorsally; tarsi not compressed. METASOMA. Petiole distinctly elongate, cylindrical, with strong longitudinal keels, predominantly glabrous dorsally, with hairs ventrally and laterally, sometimes with rudimentary foamy structures posterolaterally, with deep longitudinal groove posteroventrally; metasoma past petiole elongate, anterior margin of syntergite distinctly wider than petiole, syntergite in lateral view entirely glabrous, and highly shining, almost flat dorsally, posterior margin of syntergite and following tergites 
with fine dense punctures; posterolateral corners of tergites remarkably angular, not appressed to sternite, often flared out, loosely fitting; anterior margin of S2 with 2 hairy depressions, specialized spot on S2 not developed.

ReCognition and Relationships: Megaplastopria can be recognized by the combination of several character states, however, two of them appear constant in all species, viz., the structure of male antenna (A1 vs. $\mathrm{A} 3$, structure of A3-A14) and the presence of two hairy depressions on base of S2 in both sexes. Megaplastopria differs from Trichopria by specialized male antenna as well as by presence of two hairy pits on base of S2 in both sexes; however, several undescribed Neotropical species of Megaplastopria lack some of the generic attributes and appear closer to Trichopria.

Distribution: The genus is restricted to the Neotropics, with 12 species described. We examined rich material from CNCI with specimens from Mexico to Brazil; no specimens were examined from the Greater Antilles, but one species is described from Grenada (Lesser Antilles).

Biology: Host unknown. All members of Megaplastopria are found in lower and mid altitudes (rain and cloud forests).

\section{Mimopria Holmgren}

Figures 65, 66

Mimopria Holmgren, 1908: 346.

Atrichopria Kieffer, 1910b: 55. Synonymized by Masner, 1959: 361-367.

Kiefferopria Brèthes, 1927b: 333. Synonymized by Masner, 1959: 361-367.

Diagnosis ( $q$ ఠ): Predominantly large sized robust individuals $(3.5-5 \mathrm{~mm})$, rarely smaller; body predominantly light to dark ferrugineous, in females entirely sculptured and matte (including tegula) except metasoma past petiole sometimes contrastingly smooth and shining, sculpture of males generally finer, with parts of head and mesosoma smooth; body generally with scattered long stiff erect or slanted bristles, bristles often truncate apically; foamy structures or hairy cushions not developed; postgena rarely with golden pegs; frons armed with two to three projections; palpi very short, palpal formula
3-2; hypostomal bridge absent in that base of maxilla touches occipital flange; mesopleuron medially with shallow oblique declivity; dorsellum usually weakly defined, without keels; propodeum distinctly elongate, with median keel and plicae at most weakly developed, separated from metanotum by rather deep broad cleft; metasternum anteriorly (behind mesocoxa) without deep semicircular cleft and without forked furca ventrally.

DESCRIPTION ( $q$ む): HEAD. Head in dorsal view subangular, in frontal view rhomboidal, hypognathous, face elongate, frons armed with two to three projections, in lateral view head higher than long; antennal shelf large, with anterior margin sharply projecting, bladelike, shelf located in upper half of eye; eye medium-large, eye height usually shorter than half of head height, eye ovoid, usually highly convex, posterior orbit usually straight, ommatidia usually large and convex; ocelli large and highly convex; temple behind eye abruptly receding, sinuate or almost straight; malar sulcus not developed; mandible bidentate, lower tooth remarkably long and slender, upper tooth short and truncate; palpi relatively short, palpal formula 3 2; oral carina strongly developed; postgena rarely with row of strong golden pegs; gena and postgena without fine pilosity; postgenal cushion never developed; cheek in frontal view nonangular; hypostomal bridge not developed, base of maxilla touching occipital flange; occipital flange always well developed, broad, but only moderately steplike; female antenna 12-segmented, clava multisegmented (usually 5 segments), semiabrupt, cylindrical clavomeres slightly transverse, noncompact, A12 slightly larger than A11; A1 elongate, cylindrical, rounded apically; male antenna 14-segmented, with scattered, randomly spaced erect bristles on antennomeres A3-A13, A4 not sexually modified; A7A12 without special brushes. MESOSOMA. Mesosoma as high as wide; pronotal shoulders not developed but sides of pronotum flattened; epomium not developed; pronotum in subcervical region sometimes with dense pilosity; propleuron and anterior side of pronotum without foamy structures or cushion of hairs but sometimes with denser pilosity; cervix of prothorax relatively long; 
mesoscutum usually slightly elongate, convex in lateral view, admedian and parapsidal lines usually present; scutellum distinctly trapezoidal, anterior scutellar pit usually deep and well developed but shorter than scutellar disc, often with longitudinal grooves or rugulae on bottom; scutellar disc moderately convex, unarmed dorsally, median keel usually not developed, lateral keels not developed, sides of scutellar disc sloping roundly into axillar depression; axillar depression usually well developed, glabrous or with short, sparse pilosity; mesopleuron predominantly flat with shallow oblique declivity medially; dorsellum usually weakly defined, without longitudinal keels; dorsellum separated from propodeum by deep, broad cleft; metapleuron large, finely rugulose, usually only with few scattered hairs, rarely with fine appressed pilosity, metasternum anteriorly (immediately posterior to mesocoxa) without cleft and without forked furca ventrally; propodeum elongate, almost as long as high, with various sculpture, median keel not developed, rarely rudimentary, plica at most weakly developed; posterior margin of propodeum either generally rounded, or sharply angular and projecting, never produced into semitransparent laminae; wings primarily developed, forewing distinctly longer than body, slightly to strongly infuscate, marginal cilia extremely short, submarginal vein almost straight, relatively short, not exceeding basal third of wing length, marginal vein subtriangular, stigmal vein very rarely developed, basal vein not developed, wings secondarily missing in many female specimens; legs remarkably long and slender; femora and tibiae nonclavate, only slightly progressively incrassate, subcylindrical, all (especially hind) tarsi elongate, slightly to strongly compressed, apex of anterior tibia without special spine dorsally, anterior tibial spur short, straight, and bifid. METASOMA. Petiole in dorsal view distinctly elongate, robust, usually subcylindrical, either convex or flattened dorsally, sometimes with longitudinal carinae, in lateral view not curved, often widest in middle, with fine dense pilosity and scattered semierect bristles; metasoma past petiole remarkably short, in lateral view only slightly convex dorsally, but strongly convex ventrally; entire syntergite with sparse semierect stiff bristles; anterior margin of syntergite tightly attached to apex of petiole; anterior margin of S2 usually moderately excavate; specialized spot on S2 always distinct, either contiguous with or remote from anterior margin of $\mathrm{S} 2$; apex of female metasoma moderately pointed, apical sternite sparsely hairy.

ReCOGNITION AND RelationshiPs: Previous concepts of Mimopria (e.g., Borgmeier, 1939; Masner, 1959) also included the new genus Mimopriella. The two genera are now distinguished primarily by cephalic character states (frons armed in Mimopria, unarmed in Mimopriella), structure of male antenna, different type of setae on body (stiff apically truncate in Mimopria, decumbent and tapering apically in Mimopriella), presence (Mimopriella) or absence (Mimopria) of metasternal cleft, and shape of metasoma. Mimopria in our concept is close to Notoxoides because of the armed frons and heavily sculptured body.

DISTRIBUTION: Interestingly enough, Mimopria and Notoxoides are restricted in distribution to the tropical lowlands of continental South America (from Argentina to southern Venezuela). Masner (1959) and Loiácono (1981) keyed Mimopria species in South America.

BIOLOGY: Species of Mimopria were recorded associated with ecitonine genera $\mathrm{Eci}$ ton, Labidus, and Nomamyrmex (Loiácono, 1981). Members of Mimopria display a high degree of adaptive morphology for life with host ants, such as rugulose sculpture, specialized setae, lytic alectomy, etc. (Masner, 1976; Huggert and Masner, 1983). Unlike in Notoxoides the sex ratio is heavily slanted toward females in Mimopria; in rich CNCI material only a few males were found.

\section{Mimopriella, new genus \\ Figures 63, 64}

Diagnosis ( $q$ $\diamond)$ : Medium to large-sized individuals $(2.5-4 \mathrm{~mm})$; body in most species light to dark ferrugineous, partly smooth and shining, with patches of coriaceous sculpture, rarely entire head, mesosoma and petiole finely scaly-rugulose, tegula always smooth; body generally with scattered long straight or semidecumbent, tapered bristles; 
foamy structures or hairy cushions not developed, sometimes postgena with row of stiff golden pegs; frons unarmed; hypostomal bridge narrow or confluent with occipital flange; metasternum anteriorly (behind mesocoxa) with deep semicircular cleft; propodeum elongate, distinctly tapering posteriorly, median keel and plica at most weak or rudimentary, propodeum entirely rugulose, usually only sparsely hairy, posterior margin of propodeum often sharply projecting, without transparent laminae; entire syntergite smooth, with evenly scattered semierect yellow bristles.

DESCRIPTION ( $q$ ô): HEAD. Head perfectly globular, hypognathous, frons unarmed; antennal shelf moderate, located in middle of eye; face elongate or quadrate; eye mediumlarge, eye height subequal to half of head height, eye ovoid, higher than wide, posterior orbit straight or slightly sinuate, ommatidia usually large and convex; temple behind eye gradually roundly receding; ocelli large and highly convex; malar sulcus never developed; mandible bidentate, lower tooth longer than upper tooth, upper tooth truncate; palpal formula 5-2; oral carina strongly developed; gena and postgena usually without fine pilosity; postgenal cushion never developed, but in some species postgena with row of strong golden pegs; cheek in frontal view nonangular; hypostomal bridge very narrow, rarely even contiguous with ventral margin of occipital flange; occipital flange usually well developed, broad and steplike, rarely absent; female antenna 12-segmented, clava semiabrupt, multisegmented (5-7 segments), clavomeres always subquadrate, noncompact, with short pilosity, A12 not enlarged, A1 elongate, cylindrical, and rounded apically; male antenna 14-segmented, A3 and A4 distinctly separate, A3 slightly constricted medially with two whorls of verticillate bristles, A4 not sexually modified, A4-A13 constricted basally, distinctly knotted in distal part, with one whorl of verticillate hairs each, A7-A12 without special brushes. MESOSOMA. Mesosoma about as high as wide; pronotal shoulders usually not developed but sides of pronotum in dorsal view well visible; epomium at most rudimentary; propleuron and anterior side of pronotum without foamy structures or cushion of hairs, pro- pleuron often with fine dense pilosity; cervix of prothorax relatively long, constriction between head and mesosoma remarkable; mesoscutum usually slightly wider than long, highly convex in lateral view, usually with parapsidal keels, rarely with parapsidal sulci; scutellum distinctly trapezoidal, anterior scutellar pit usually shallow, slightly transverse, distinctly shorter than scutellar disc, often with fine longitudinal keels, rarely pit sharply margined; scutellar disc moderately convex, unarmed dorsally, usually with moderate median keel, lateral keels in females usually weakly developed, in males moderately developed; axillar depression in females generally not well defined, rudimentary or absent; axilla posteriorly sloping down roundly, axillar depression in males usually well defined and axilla posteriorly sharp; mesopleuron in most species strongly convex, rarely flat; dorsellum defined, longitudinal keels usually weak; metapleuron large, coarsely rugulose, usually only with few scattered hairs, rarely with fine appressed pilosity; metasternum anteriorly (immediately posterior to mesocoxa) with deep semicircular cleft; propodeum remarkably elongate, tapered posteriorly, entirely rugulose, median keel generally weakly developed, at most indicated only anteriorly, propodeal plica indistinct; posterolateral corners of propodeum sometimes strongly produced; posterior margin on propodeum deeply excavate, posterior margin not produced into transparent laminae; wings primarily developed, forewing distinctly longer than body, generally slightly infuscate in basal third, sometimes bronzy, in some individuals reduced to stumps; submarginal vein relatively short and running strongly adjacent to anterior margin of wing; stigmal vein relatively well developed; basal vein not developed; legs very long and slender; hind femur basally slightly compressed and curved, apex of all femora with flaps, hind tibia cylindrical, only shortly attenuate basally; tarsi elongate, moderately to strongly compressed; apex of anterior tibia without specialized spine dorsally. METASOMA. Petiole distinctly elongate, subcylindrical, moderately to distinctly tapered posteriorly, in lateral view slightly curved, without longitudinal keels, with fine dense pilosity and with scattered semierect bristles; metasoma 
past petiole often highly campanulate, convex dorsally, entire syntergite with scattered semierect yellow bristles, syntergite smooth and shining, anterior margin of syntergite in lateral view usually elevated and overlapping base of petiole, anterior margin of syntergite loosely attached to petiole; anterior margin of S2 deeply excavate, semicircular, permitting maximum down-flection between petiole and S2, specialized spot on S2 usually located directly in excavation on anterior margin of S2 (usually not easily visible), or rarely remote from it; apex of female metasoma moderately pointed, apical sternite only sparsely hairy.

TyPE SPeCIES: Mimopria pentatoma Borgmeier, by present designation.

RECOGNITION AND RELATIONSHIPS: Until now, members of this new genus were classified in Mimopria (Borgmeier, 1939; Masner, 1959; Loiácono, 1981). The following species of Mimopria are here transferred to Mimopriella (new combinations): $M$. pentatoma Borgmeier and M. splendens Borgmeier. The two genera can be easily distinguished by cephalic character states (head globular with frons unarmed in Mimopriella vs. head subangular with frons armed in Mimopria), differences in palpal formula (52 Mimopriella, 3-2 Mimopria), presence (Mimopriella) or absence (Mimopria) of metasternal cleft, differences in setae (tapering in Mimopriella, stiff and truncate apically in Mimopria). Generally members of Mimopriella exhibit finer sculpture and are smaller than members of Mimopria. The two genera are also distinct in shape of metasoma past petiole which is highly convex and campanulate in Mimopriella, and only moderately convex in Mimopria. The verticilate flagellomeres in males of Mimopriella are similar to those in Notoxoides, but distinct from scattered hairs on flagellomeres in Mimopria. Acanthopria males differ by fused A3-A4, and Leucopria males by two whorls of bristles on A4-A13.

ETYMology: The name Mimopriella is a diminutive of Mimopria, implying the generally smaller and gracile habitus of members as compared with more robust members of Mimopria; the gender is feminine.

Distribution: The distribution of Mimopriella is wider and more ecologically di- verse than that of Mimopria; consequently, we examined numerous species (CNCI) from both lowland rainforests and cloud forests of continental South America (Argentina, Brazil, Colombia, Ecuador, Peru, Surinam, Venezuela) as well as Central America (Panama, Costa Rica).

BIOlOGY: Members of Mimopriella are closely associated with various ants. Loiácono (1981) lists ecitonine genera Nomamyrmex and Neivamyrmex. We examined specimens collected from colonies of Labidus sp. (Ecitonini) and one species taken in Costa Rica from a nest of Trachymyrmex opulentus (Mann) (Attini). Mimopriella appears morphologically less modified than, for example, Mimopria, Notoxoides, etc. However wing alectomy was observed among few individuals; individuals are also frequently collected in light traps.

\section{Mitropria Ogloblin Figure 67}

Mitropria Ogloblin, 1958: 13.

DiAgnosis ( $q$ ô): Minute-sized individuals $(1.1 \mathrm{~mm})$; body light brown, head and mesosoma with scattered semidecumbent hairs; hairy cushions present, foamy structures not developed; frons armed, with several sharp points; female antenna 11-segmented, with abrupt 3-segmented clava, male antenna 13segmented, slightly subclavate, with antennomeres gradually incrassate toward apex; basal vein in forewing not developed; anterior margin of syntergite straight or weakly excised medially.

DESCRIPTION ( 9 † $)$ : HEAD. Head in dorsal view slightly elongate, subangular, frons armed, with several sharp points; antennal shelf distinctly projecting, temple distinctly longer than eye; antennal shelf in lateral view distinctly prominent; torulus in level of lower half of eye; eye relatively small, subcircular, shorter than postgena, only slightly larger than malar space, posterior margin of eye rounded, ommatidia rather large and slightly convex; oral carina minute; postgenal cushion present; occipital flange minute; mandible bidentate, distinctly projecting, hypognathous, mandibular condyle with distinct raised rim; clypeus strongly convex; hypostomal bridge well developed, palpal formula 
4-2; female antenna 11-segmented, with abrupt 3-segmented clava, A1 elongate cylindrical, not armed apically; male antenna 13segmented, slightly subclavate, with antennomeres gradually incrassated toward apex, A2 unusually large, A5-A12 transverse, almost beadlike, with abundant scattered pilosity, A13 largest, A4 curved, sexually modified, antennomeres without specialized brushes. MESOSOMA. Pronotum in dorsal view weakly developed, pronotal shoulders not developed, sides of pronotum rather flat, epomium absent, pronotal cushions strongly developed; mesoscutum as long as wide, only slightly convex, with weak declivities in notaular region, notaulus not clearly developed; anterior scutellar pit rather shallow, subrectangular, shorter than scutellar disc, scutellar disc subcircular, slightly convex, without median keel, posterior margin of axilla rounded, axillar depression minute, with fine pilosity, median oblique line of mesopleuron weakly indicated, sternaulus not present; dorsellum weakly developed, with three indistinct keels; metapleuron densely hairy; propodeum rather short, with distinct median keel, plica well developed, area between plicae and keel almost glabrous, posterior margin of propodeum arcuate; wings relatively short, with long marginal cilia; submarginal vein distinctly remote from margin, marginal and stigmal vein subtriangular, venation distinctly exceeding basal third of wing length, basal vein not developed; hind wing with submarginal vein weakly developed; legs relatively short, femora and tibia clavate distally, tarsi not compressed; apex of foretibia dorsally without spine. METASOMA. Petiole only slightly elongate, cylindrical, with dense fine pilosity; metasoma past petiole, elongate, slightly convex dorsally, anterior margin of syntergite straight or weakly excised medially; S2 with two hairy depressions anterolaterally; apex of metasoma in female only shortly pointed.

ReCognition and Relationships: Mitropria is an intermediate genus between Basalys and Doliopria; with the former it shares type of female clava, structure of head and mesosoma; with the latter the absence of basal vein as well as 11-segmented female antenna. However the structure of male antenna is peculiar to Mitropria. We prefer to rec- ognize at this moment Mitropria as an independent genus.

DistRIBUTION: Mitropria. coronata Ogloblin was described from Argentina. We examined the type material of the above species, as well as an undescribed species from Brazil.

BIOLOGY: Unknown.

\section{Monelata Foerster}

Figures 68, 69

Monelata Foerster, 1856: 123, 127.

Corynopria Haliday, 1857: 170. Synonymized by Dalla Torre, 1898b: 598.

Streptopria Maneval, 1939: 168. Synonymized by Masner and Sundholm 1959: 161-168.

Diagnosis ( $+\stackrel{0}{0})$ : Small-sized individuals (1-1.5 mm), body generally elongate, body color from dark brown (mostly Nearctic species) to light brown or reddish (mostly Neotropical species), with head always darkest, body smooth and shining, head and mesosoma with scattered semierect hairs, body with massive hairy cushions, specialized dense pilosity, and some foamy structures; female antenna 13-segmented, abruptly clavate (1-segmented), with A13 remarkably enlarged; male antenna 14-segmented, with A4 not sexually modified; cervix of pronotum densely hairy, massive pronotal and propleural cushions confluent into complete hairy collar ventrally and dorsally; anterior scutellar pit not developed; metapleuron densely covered with appressed pilosity, pilosity continuing on metasternum, completely surrounding hind coxae; petiole entirely covered by dense specialized pilosity of different types; S2 with large and massive anterior cushion of specialized pilosity.

DESCRIPTION ( $q$ ô): HEAD. Head in dorsal view subglobular, frons unarmed, antennal shelf relatively large, not margined posteriorly; head in lateral view with antennal shelf considerably projecting, level of torulus in upper half of eye; eye of various sizes, subequal to or larger than malar space, posterior orbit of eye not sinuate; ommatidia rather small, not convex; oral carina almost absent; postgenal cushion massive, not contiguous either dorsally or ventrally; occipital flange moderately developed; mandible bidentate; hypostomal bridge well developed; palpi 
long and slender, palpal formula 5-2; female antenna 13-segmented, abruptly clavate (1segmented), with A13 remarkably enlarged, ovoid, without pit ventrally, A5-A10 minute, A1 long, cylindrical, unarmed apically; male antenna 14-segmented, antennomeres cylindrical, moderately to strongly elongate, with moderate to long scattered hairs, A4 not sexually modified, A3 subequal in length to other segments, distinctly shorter than A1, A1 long, cylindrical, unarmed apically, special brushes on A7 to A12 not developed. MESOSOMA. Pronotum in dorsal view moderately developed, pronotal shoulders not developed, epomium absent, cervix densely hairy, massive pronotal and propleural cushions confluent into complete hairy collar ventrally and dorsally; mesoscutum slightly elongate, only moderately convex to nearly flat, without lines or depressions; anterior scutellar pit not developed, rarely replaced by very shallow concavity; axilla fused with scutellar pit area and scutellar disc in one plate; scutellar disc with sides slightly converging posteriorly, in one undescribed species with moderated longitudinal keel; posterior margin of axilla rounded, axillar depression very small, hairy; mesopleuron almost flat, glabrous, oblique subhorizontal line weakly developed or absent, sternaulus not developed, ventral side of mesopleuron (between fore and middle coxae) with fine pilosity; dorsellum weakly developed, with indistinct keels, metapleuron densely covered with appressed pilosity; pilosity continuing on metasternum completely surrounding hind coxae; propodeum elongate, with distinct median keel, keel usually pointed anteriorly or lamellate, keel usually glabrous, adjacent plical area also often glabrous, remaining propodeum densely hairy, plica not developed, posterior margin of propodeum moderately excavate; forewing rather elongate and narrow, anterior margin sometimes slightly sinuate, apex often truncate to emarginate, marginal cilia remarkably long, including on anterior margin past marginal vein, microtrichia on disc relatively strong; submarginal vein usually straight, strongly approximated to foremargin, long, distinctly exceeding basal third of wing length, marginal vein long, keel shape, stigmal vein absent, anterior margin of basal vein not de- veloped but wing often with transverse darker strip below apex of marginal vein; hind wing with distinctly sclerotized submarginal vein; wings shortened or absent in some undescribed species; legs long and slender, with femora and tibia distinctly clavate in distal half; apex of foretibia with minute spine dorsally, tarsi long and slender, not compressed. METASOMA. Petiole distinctly elongate, cylindrical, entirely covered by dense specialized pilosity of different types, both dorsally and ventrally, pilosity posterodorsally partly overlapping anterior margin of syntergite; metasoma past petiole distinctly elongate, only slightly convex dorsally, anterior margin of syntergite straight and generally covered with narrow band of modified pilosity, pilosity continuing ventrally forming uninterrupted hairy ring; posterior part of metasoma characteristically subangular with short, broadly triangular point in female; S2 anteriorly with large and massive cushion of specialized pilosity.

RECOGNITION AND Relationships: The abundance and different types of pilosity make Monelata unique in the Diapriinae. The females are easily recognized because of the unique structure of the antenna. The males, however, were described as a different genus (Maneval, 1939) and only recently properly distinguished from some males of Trichopria (=Phaenopria) (Pschorn-Walcher, 1956); the principal difference is in the structure of A4 and pubescence of propodeum, petiole, and S2.

DISTRIBUTION: The genus is found both in North and South America (except in Chile), with many species still undescribed.

BIOLOGY: Host unknown. Members were once observed on stable manure (PschornWalcher, 1956).

\section{Myrmecopria Ashmead Figures 70, 71, 72}

Myrmecopria Ashmead, 1893: 407-446.

Diagnosis ( $q$ o ): Medium-sized individuals $(2-2.7 \mathrm{~mm})$, with sexes somewhat similar in general appearance; body light colored, honey-yellow to ferrugineous, extent of rugulose sculpture distinctly greater in female than in male, body with scattered long semidecumbent golden bristles; foamy structures 
and cushions of hairs not developed; posterior ocelli located posterior to ocular zone (dorsal view); entire head with rough sculpture, irregularly corrugated, especially on postgena, posterior temple and occiput, especially in female; palpi rudimentary, extremely short, not protruding, palpal formula appearing $1-0$; petiole in dorsal view distinctly campanulate; apex of tibiae, especially fore and mid with strongly projecting spine on inner side; tibial spurs rudimentary, formula 1-1-1; tarsi, especially fore and mid, remarkably short, compressed, almost foliaceous; petiole robust, broadly campanulate.

Description ( $q$ o $)$ : HEAD. Head in dorsal view slightly elongate, widest across posterior temples; temple behind eye straight, moderately diverging posteriorly; antennal shelf relatively large, deep, sharply margined posteriorly, especially in female, frons armed with three moderate projections; posterior ocelli located posterior to ocular zone (dorsal view); head in lateral view with antennal shelf in upper half of eye; eye relatively small, with posterior orbit not sinuate, eye slightly shorter or subequal to postgena, higher than malar space; ommatidia large and convex, raspberry-like, each ommatidium subequal in size to ocellus; entire head with rough sculpture, irregularly corrugated, especially on postgena, posterior temple and occiput, especially in female; mandible bidentate, slender, with both teeth long and pointed, lower tooth longer, with upper tooth not truncate; epistomal sulcus indicated basally; palpi rudimentary, extremely short, not protruding, palpal formula appearing 1-0; oral carina moderate; head in ventral view with hypostomal bridge moderate, well defined; occipital flange rudimentary, indicated by irregular rugulosity; female antenna 11segmented, clava indistinct, 5-6-segmented, with moderate gaps, progressively incrassate, A11 largest; A1 ( + đิ) robust, cylindrical, not armed apically, with scattered pustules; male antenna 14-segmented, A14 ovoid, subequal in size to A13, apical half of antenna with beadlike segments, A3 distinctly elongate, rest of antenna with almost beadlike segments, A3 and A4 sexually modified, with sharply pointed carina on external apical corner, with scattered semidecumbent hairs, A7-
A12 without specialized brushes. MESOSOMA. Pronotum in dorsal view with sides well visible; pronotal shoulders not developed; epomium absent; mesoscutum as long as wide, moderately convex; parapsidal lines delicate; tegula smooth; anterior scutellar pit small and shallow, shorter than scutellar disc, with several longitudinal ridges between axilla and scutellar disc; scutellar disc relatively large, semicircular, moderately convex, at most with delicate median longitudinal keel, lateral keel of disc weakly defined; posterior margin of axilla roundly sloping down; axillar depression small but deep; mesopleuron distinctly convex, subrectangular, with distinct oblique submedian line; dorsellum weakly defined; metapleuron almost glabrous, entirely finely rugulose, with massive deep excavation along anterior margin; anterior margin of propodeum with broad transverse cleft; propodeum in dorsal view relatively long, entirely rugulose, median keel variable, from distinct to almost absent, plica usually absent, rarely delicate, posterior margin of propodeum sharp bladelike, with deep median V-shaped excision; wings primarily present, forewing relatively long and narrow, below stigmal vein with only slight infuscation in basal vein area, with moderately long marginal cilia widely exceeding metasoma; stigmal vein distinctly developed; legs long and strong, hind coxa robust, distinctly elongate, femora subclavate, distinctly constricted basally, middle tibia distinctly arcuate, hind tibia remarkably compressed anteriorly, in lateral view hind tibia with subparallel sides, tibial spurs rudimentary, formula 1-11 , apices of tibiae with strongly projecting spine on inner side; pustulae present on fore and mid femora ventrally; tarsi, especially fore and mid, remarkably short, compressed, almost foliaceous, fore and mid tarsi moderately to distinctly transverse; claws relatively small. METASOMA. Petiole in dorsal view robust, broadly campanulate, entirely finely rugulose, without keels, strongly constricted anteriorly, in lateral view subtriangular (especially in female), expanding posteroventrally, petiole in ventral view with median deep excavation flanked laterally by two sharp keels, posterior apex of petiole strongly necklike constricted; metasoma past petiole smooth, in lateral view considerably 
convex both dorsally and ventrally, entire syntergite with scattered semidecumbent setae; anterior margin of S2 with flexed transparent rim, specialized spot not developed.

RECOGNITION AND RELATIONSHIPS: Myrmecopria is peculiar in several character states: remarkably reduced palpi, presence of strong spine projection on inner apices of tibiae, and reduction of tibial spurs with unique formula $1-1-1$. The tarsi are one of the most compressed among all myrmecophilic genera. Myrmecopria is related to Apopria, Ecitovagus, and Townesella; from Apopria it differs by the presence of eyes and structure of petiole; from Ecitovagus principally by nonelevated anterior lobe of mesoscutum, different shape of propodeum, 11-segmented antenna, and from Townesella by armed frons, with deeply margined antennal shelf and corrugated sculpture of head.

Distribution: The only known species, Myrmecopria mellea (Ashmead), is recorded from Southeastern USA, east of Mississippi, Florida to North Carolina.

Biology: Myrmecopria mellea is associated with Neivamyrmex opacithorax (Emery) and N. carolinense (Emery) (Masner, 1964). Majority of specimens were caught in light traps. Wing allectomy was observed in two females collected in raid column of $N$. carolinense in Alabama.

\section{Neivapria Borgmeier \\ Figure 73}

Neivapria Borgmeier, 1939: 543.

Diagnosis ( $q$ ): Medium-sized individuals (2 mm); body light-colored, honey yellow, highly shining, with only very sparse semidecumbent pale hairs; foamy structures and cushions of hairs not developed, but few areas of dense pilosity occur; sculpture of head rough rugulose, almost corrugated, especially on postgena; strong keel running from OOL area down on temple and postgena, almost reaching malar area; occiput abruptly sloping down behind posterior ocelli; entire side of pronotum remarkably rugulose, epomium strongly developed, bladelike sharp; scutellar disc strongly subcircular; metapleuron remarkably smooth, mirrorlike shining and glabrous; median part of petiole with transverse scalelike node, with posterior margin sharply carinate; S2 produced ventrally, with dense tuft of hairs at meson.

DESCRIPTION ( $q$ ): HEAD. Head in dorsal view subhexagonal, slightly transverse, frons medially with sharp keel, antennal shelf rather large, not completely margined posteriorly; temple behind eye remarkably short; occiput abruptly sloping down behind posterior ocelli; head in lateral view with antennal shelf distinctly protruding, level of torulus in middle of eye; eye remarkably large, distinctly higher than long, larger than half of head height, distinctly larger than malar space, posterior orbit of eye almost straight; ommatidia large, highly convex, raspberry-like; sculpture of head rough rugulose, almost corrugated, especially on postgena; strong keel running from OOL area down on temple and postgena, reaching almost malar area; OOL subequal to LOL; oral carina well developed; occipital flange rudimentary but steplike; head in frontal view with face slightly wider than higher, mandible bidentate, teeth subequal, sharply pointed; clypeus relatively well indicated by depressions in epistomal area; head in ventral view with hypostomal bridge present; palpi very short, palpal formula 32 ; antenna 12-segmented, with indistinct nondifferentiated multisegmented clava (6-7 segments), A12 subequal to A11 in size, clavomeres with narrow gaps; A1 robust, cylindrical, unarmed apically, but with rather sharp rim. MESOSOMA. Pronotum in dorsal view relatively well developed, pronotal shoulders not developed, entire side of pronotum remarkably rugulose, epomium strongly developed, bladelike sharp; mesoscutum slightly longer than wide, distinctly convex, parapsidal and admedial lines not developed; tegula well developed; anterior scutellar pit subcircular, relatively small and shallow, shorter than scutellar disc; scutellar disc remarkably subcircular, lateral keels not developed, sides sloping round into axillar depression; posterior margin of axilla perfectly rounded, axillar depression small, nonexcavate under axilla; mesopleuron distinctly flat, subrectangular, oblique submedian line fine; dorsellum well defined with sharps keels, middle keel bladelike; metapleuron remarkably smooth, mirrorlike shining and glabrous, with sharp keel on ventral margin; propodeum subquadrate, bunlike, median 
keel moderate or absent, plica not developed but sides of propodeum sharply carinate, surface of propodeum predominantly smooth, posterior margin of propodeum moderately arcuate, very sharp, propodeum in lateral view convex, not sloping, flattened dorsally; wings primarily developed but lost in all specimens examined; legs long and strong, coxae strong, hind coxa pear-shaped, femora moderately clavate, tarsi only moderately compressed. METASOMA. Petiole highly modified, strongly necklike constricted anteriorly and posteriorly, median part with transverse scalelike node, posterior margin sharply carinate, petiole in lateral view higher than long, with deep horizontal cleft at meson; metasoma past petiole highly convex dorsally and ventrally, anterior margin of syntergite sloping roundly to petiole, ecarinate; S2 produced ventrally, with dense tuft of hairs at meson, specialized spot not visible.

ReCOGNITION AND Relationships: Neivapria is recognized by the following peculiar character states: general shape of head (occiput, postgenal keel, sculpture), sculpture of metapleuron, shape of petiole, and tuft of hairs on S2. Neivapria resembles Asolenopsia in some cephalic character states; however it remains a rather isolated genus because of many peculiarities.

MALE: Unknown.

Distribution: We examined two species from Brazil (including paratype of $N$. penicillata Borgmeier).

Biology: Numerous females of $N$. penicillata were collected from columns of $\mathrm{Nei}$ vamyrmex minensis (Borgmeier). Borgmeier (1939) assumed that N. penicillata is primarily (hereditary) apterous; however, the tegula is normally developed and stumps of wings indicate secondary loss of wings due to lytic alectomy.

\section{Notoxoides Ashmead \\ Figures 74, 75, 76}

Notoxoides Ashmead, 1903: 30.

Notoxopria Kieffer, 1910b: 39. Synonymized by Masner, 1977: 33-36.

Philolestes Kieffer, 1922: 205. Synonymized by Masner, 1977: 33-36.

Psilogasteroides Brèthes, 1911: 209-210. NEW SYNONYMY (described in Chalcidoidea).
Diagnosis $(9$ đ): Medium to very largesized individuals ( 3.5 to $6.5 \mathrm{~mm}$ ) with sexes considerably dimorphic (note separate descriptions of sexes below); body predominantly light to dark ferrugineous, entirely sculptured and matte (including tegula) or partly sculptured and partly shining; sculpture of males generally finer, with large parts of head and mesosoma smooth; body generally with scattered long semidecumbent bristles; foamy structures or hairy cushions not developed; head in female in lateral view characteristically topped, eye distinctly smaller in relation to large gena; frons armed; female pronotum anterodorsally with hump or horn, in male with sharp margin and epomial carina; metasternum (between mid and hind coxae) usually with strong furca; stigmal vein unusually long and slanted; female tarsi strongly compressed.

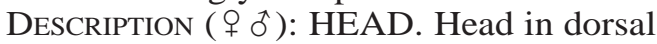
view strongly tapered behind eyes, with occiput and temples very long, head hypognathous, frons armed with three projections, middle projection often blade like, head in lateral view characteristically topped, eye, ocelli and antennal shelf located very high on forehead, eyes relatively small and postgena distinctly large; antennal shelf large, with anterior margin sharply projecting, bladelike; torulus located in upper half of eye; eye height distinctly shorter than $1 / 2$ head height, eye ovoid, posterior orbit usually straight, ommatidia usually large and convex; ocelli large and semiconvex; malar sulcus not developed, malar space usually relatively large; mandible bidentate, with lower tooth longer, sometimes mandible unequal, rarely one mandible subtridentate; palpi always short, palpal formula 3-2 or 4-2; oral carina moderately developed; gena and postgena almost glabrous, rarely with patches of pilosity; postgenal cushion never developed, cheek in frontal view nonangular; hypostomal bridge relatively narrow; occipital flange always present but usually nonabrupt or only moderately steplike; female antenna usually 11-segmented, rarely 12-segmented, clava multisegmented (5-6 segments), semiabrupt, cylindrical, clavomeres usually slightly transverse, noncompact, rarely almost beadlike, apical clavomere slightly more enlarged than preceding clavomere, A1 elongate, cylindri- 
cal, rounded apically; male antenna 14-segmented, A4 not modified, A4-A13 with one whorl of verticillate bristles. MESOSOMA. Mesosoma moderately to distinctly higher than wide; pronotum anteromedially produced into hump or cylindrical horn, apex of horn often slightly notched medially, horn often overlapping occiput, or horn not developed but pronotal shoulders approximated and angularly projecting; epomium not developed; propleuron and anterior sides of pronotum without foamy structures or cushions of hairs, rarely anterodorsal part of pronotum with dense pilosity; cervix of prothorax relatively short; mesoscutum distinctly elongate, parapsidal lines or impressions often developed, mesoscutum often with longitudinal impression anteromedially; scutellum distinctly trapezoidal, anterior scutellar pit moderately deep, often with irregular longitudinal keels, pit shorter than scutellar disc; scutellar disc moderately to distinctly convex, subcircular, pillow-shaped, unarmed dorsally, median keel not developed, lateral keels usually delicate, rarely sharp; axillar depression moderately to well developed; mesopleuron rather flat, usually with deep oblique submedial declivity, lower half of mesopleuron rarely with dense horizontal striate; dorsellum well defined, with longitudinal keels, dorsellum separated from propodeum by deep cleft; metapleuron large, rugulose, without fine pilosity, separated dorsally from propodeum by deep horizontal declivity, declivity rarely absent; metasternum (between mid and hind coxae) usually with deeply bifurcate projection, furca closely flanked by middle and hind coxae, rarely furca not developed; propodeum relatively short, highly topped, median keel usually not developed, plica at most rudimentary, propodeum without fine pilosity, posterior margin of propodeum usually sharp, posterolateral corners often projecting; wings primarily developed, distinctly longer than body, clear or slightly infuscate, with arc of infuscations below marginal vein, stigmal vein unusually long, fingerlike, bent obliquely, wings secondarily missing in some individuals; legs long and strong, femora and tibiae nonclavate, subcylindrical, tarsi strongly compressed; apex of anterior tibia without specialized spine dorsally. METASOMA. Peti- ole distinctly elongate, robust, usually subcylindrical, always convex dorsally, often with transverse knot posteriorly, in lateral view strongly sloping down posteriorly in front of syntergite; metasoma past petiole in lateral view only slightly convex dorsally, moderately to strongly convex ventrally, entire syntergite with sparse semierect bristles, syntergite often partly to entirely sculptured and matte, anterior margin of syntergite tightly attached to base of petiole; anterior margin of S2 moderately to deeply excavate, rim either complete or broadly effaced medially; specialized spot on S2 usually located in wall of anterior margin of S2, rarely remote from anterior margin; apex of metasoma moderately pointed, apical sternite only sparsely hairy.

DESCRIPTION (ठ̋): Males differ from females in following characters: head usually subglobular, frons with only median process, keel-like, eye generally large, occipital flange well developed, fairly steplike, irregularly rugulose; palpal formula 5-2; postgena usually with dense pilosity; antenna 14-segmented, long and slender, A3 with two whorls of bristles, A4-A13 with one whorl of bristles on distal knot or multiple bristles on knot; mesosoma less compressed; pronotum without distinct hump or horn anterodorsally, but with sharply raised margin or with humped shoulders, sharp epomial carina descending down pronotal sides, anterodorsal corner of pronotal sides with distinct irregular striae or rugulose sculpture; lateral keels of scutellar disc generally better developed; metasternal furca usually less developed or reduced to simple hump; metapleuron and sides of propodeum with fine pilosity, median propodeal keel and plica well developed; legs generally more slender, tarsi only moderately compressed; petiole cylindrical, usually with longitudinal keels or rugosity and rather abundant pilosity; syntergite with scattered bristles only on posterior half; anterior margin of S2 with uninterrupted sharp margin; specialized spot on $\mathrm{S} 2$ not visible.

RECOGNITION AND RELATIONSHIPS: Originally the sexes of this genus were treated under two generic names, males as Notoxoides, females as Notoxopria. Masner (1976) synonymized Notoxopria and Philolestes with Notoxoides. Notoxoides is unique among re- 
lated ecitophilic genera, principally in shape of female head, and armature of pronotum and metasternum. Notoxoides shares armed frons with Mimopria, Philolestoides, Ecitovagus, and Myrmecopria; from Mimopria it differs by long slender stigmal vein and lack of stiff bristles on the body; from Philolestoides principally by head behind eyes with long temples and long occiput. The present diagnosis of Notoxoides includes an extralimital new species from Brazil (Bahia; CNCI), with 12-segmented antenna in female, pronotal horn replaced by approximated humped pronotal shoulders, median keel of propodeum well developed, etc.

DisTRIBUTION: The present known distribution of the genus is restricted to lowland rainforests of continental South America. Six species were described (Mann, 1923; Borgmeier, 1939; Loiácono, 1981; Kistner and Davis, 1989); we examined several undescribed species from South America. Loiácono (1981) keyed Neotropical species.

Biology: Members of Notoxoides display some of the most advanced associations with ants. So far, ants of genus Neivamyrmex and Eciton (Ecitonini) were recorded as hosts (Loiácono, 1981). Detailed biological study was published by Kistner and Davis (1989). Adult wasps are frequently collected in light traps. Wings may be lost to lytical alectomy as indicated by shrivelled wing rudiments in some specimens.

Omopria, new genus

Figure 77

Diagnosis $(q \hat{o})$ : Small-sized individuals $(1.7 \mathrm{~mm})$, short and robust; body chestnut brown, legs and antennae distinctly lighter; body predominantly smooth and shining; head and mesosoma with scattered, straight, strong hairs, hairs truncate apically; hairy cushions and foamy structures not developed; female antenna 12-segmented, clava spindle-shaped, nonabrupt, multisegmented, subcompact, clavomeres transversely rectangular, with very narrow gaps; male antenna 14-segmented, A3-A13 slightly longer than wide, ovoid, with scattered nonwhorled semierect hairs, A4 not modified; pronotum dorsally strongly developed (laterad mesoscutum), with massive shoulders and sharp edges; epomium developed; dorsum of propodeum in lateral view mostly subhorizontal, with median keel strongly projecting, spikelike; coxae remarkably short, subcircular.

DESCRIPTION ( + † $)$ : HEAD. Head in dorsal view subglobular; frons unarmed; antennal shelf developed, carinate anteriorly; head in lateral view with torulus in lower half of eye; eye relatively small, short oval, subequal to malar space, ommatidia moderately large; oral carina not projecting anteriorly; postgenal cushion not developed; occipital flange not developed; head in frontal view subcircular; mandible short, subtridentate; head in ventral view with hypostomal bridge extremely narrow, reduced almost to point; palpi extremely short, palpal formula 2-1; female antenna short, stout, 12-segmented with nonabrupt spindle-shaped 6-segmented clava; clavomeres subcompact, moderately flattened ventrally, A12 longest, with no ventral pit; male antenna threadlike, 14-segmented, A3-A14 with scattered long, nonwhorled, semierect hairs; A4 not modified. MESOSOMA. Mesosoma relatively short, stout; pronotum dorsally strongly developed (laterad mesoscutum), with massive subangular shoulders and sharp edges distinctly raised above adjacent margins of mesoscutum; epomium developed; side of pronotum with no hairy cushion along anterior margin; propleuron with fine pilosity; mesoscutum distinctly wider than long, remarkably flattened, admedian and paraspidal lines not developed, humeral and suprahumeral sulci moderately developed; anterior scutellar pit shallow, transversely oval, subequal in size to axilla, distinctly shorter than scutellar disc; scutellar disc flattened dorsally, subrectangular, with no lateral keels, lateral or posterior pits absent; posterior margin of axilla sharp; axillar depression large, smooth, with only scattered pilosity; mesopleuron almost flat, median oblique line rudimentary; sternaulus not developed; posterior margin of mesopleuron noncrenulate; metanotum relatively broad, smooth, and glabrous; dorsellum with three irregular keels; metapleuron not distinctly excavate anteriorly, rugose, with fine pilosity; propodeum relatively short and broad, dorsum of propodeum in lateral view mostly subhorizontal, with median keel strongly projecting, spikelike, posterolateral corners 
bluntly projecting, posterior margin of propodeum excavate, semicircular; nucha short, smooth and glabrous; forewing relatively short, almost spoonlike, with long stiff bristles between tegula and marginal vein, with moderate marginal cilia; wing venation not exceeding basal third of wing length, submarginal vein not upcurved, marginal vein wedgelike, stigmal vein shortly oblique, no other vein present; hind wing with submarginal vein incomplete; legs relatively short and stout, coxae remarkably short, subcircular; hind femur shortly clavate, hind tibia moderately clubbed; tarsi not distinctly compressed; apex of foretibia without specialized spine dorsally. METASOMA. Metasoma short and robust; petiole short and stalky, wider than long; metasoma past petiole distinctly flattened dorsally; anterior margin of syntergite only slightly wider than petiole, not notched medially; apex of female metasoma short and triangular; base of S2 without specialized pit.

TYPE SPECIES: Omopria brevipalpis, new species (described below), by present designation.

ReCOGNITION AND RELATIONSHIPS: Omopria is unique among all genera of the Diapriinae for highly apomorphic structure of pronotal shoulders. It could be compared with Acanthopria, from which it differs primarily by absence of foamy structures and strongly reduced palpi, in males also by nonwhorled flagellum with A3 and A4 clearly separated. Omopria shares some similarity with Szelenyiopria particularly in structure of propodeum and presence of stiff, truncate setae on head and mesosoma.

ETYMOLOGY: From omos (Greek) meaning "shoulder", and pria (Latin) meaning "little wasp"; the gender is feminine.

DISTRIBUTION: At present we recognize the single species, Omopria brevipalpis, new species, from Brazil and Argentina.

BIOLOGY: The host is unknown; however, judging by general habitus and color of the body, specialized pilosity, and reduced palpi, we presume a possible association with ants.

Omopria brevipalpis, new species Figure 77

DESCRIPTION: Holotype $q$ : Length $1.7 \mathrm{~mm}$; body dark chestnut brown; metasoma includ- ing petiole light brown, tegula, antenna, and legs including coxae yellowish brown; forewing with very slight infuscation; head, most of mesosoma and metasoma past petiole smooth and shining. HEAD. Head in dorsal view transverse, wider than long (41:34); eye longer than temple (14:10); head in lateral view slightly higher than long (39:34); eye as large as malar space (12:12); antennal segments in relative proportions (25:7), (10:5), (7:5), (7:5.5), (6:6), (6:7), (6:8.5), (7:10), (7: 10), (7:10), (7:10), (13:9). MESOSOMA. Mesosoma in relative proportions length: width:height (70:45:41); cervix with irregular longitudinal rugulosity; shoulders of pronotum with several stiff bristles and few shorter appressed hairs: mesoscutum broadly transverse, wider than long (37:26), with two pairs of stiff setae; axilla with two pairs of stiff bristles in extreme corners; scutellar disc with two pairs of stiff bristles at sides; propodeum dorsally and at sides with fine rugulose sculpture and with dense pilosity especially at sides; apex of marginal vein with two long tapered bristles; venation in forewing not exceeding basal third of wing length (40:120). METASOMA. Petiole short, cylindrical, wider than long (13:10), with short dense pilosity dorsally and with pair of long bristles laterally; syntergite smooth, shining, glabrous, without micropunctures; S2 with long, dense, semiappressed hairs.

MALE: Differs from female principally in antennal structure; antennal segments in relative proportions $(25: 7),(9: 6),(12: 5.5),(13:$ 5.5), (11:6), (11:6), (10:5.5), (10:5.5), (10: $5.5),(10: 6),(10: 6),(10: 6),(10: 6),(14: 5)$.

TyPe Material: 11 $\uparrow$. Holotype, $q$ (CNCI no. 22458), BRAZIL, Guanabara, Represa Rio Grande, March 1972, F.H. Oliveira. Allotype, ô, same data as holotype (A3 and A4 of right antenna partly fused dorsally). Paratypes, 19 , same data as holotype, January 1968, M. Alvarenga; 10 , same as holotype, December 1967; 1 웅, Mato Grosso, Sinop, December 1975, M. Alvarenga, MT; 19 , Districto Federal, Brasilia, R.L. Vianna, IBGE, Res. April 14-20, 1983; 1 웅, Londrina, Mata dos Godoy, January 28-31, 1990, S.A. Marshall, PT; 20 , ARGENTINA, Rio Ceballos, January 24, 1974, I. Redolfi. 
ETymology: The species epithet refers to its unusually short palpi.

Distribution: Argentina, Brazil.

BIOLOGY: Unknown.

VARIATION: In spite of considerable distribution, very little variation was encountered; some males were slightly smaller than the

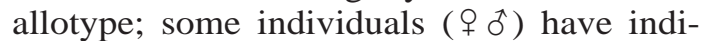
cation of fine horizontal striae on the side of pronotum, better developed than in the holotype.

\section{Philolestoides Ferrière}

Figure 84

Philolestoides Ferrière, 1929: 160.

Diagnosis ( $q$ ): Medium-sized individuals (about $3 \mathrm{~mm}$ ); body light brown to ferrugineous, partly or predominantly sculptured, tegula smooth; body with scattered yellowish pilosity; foamy structures or hairy cushions not developed; head subangular, entire surface of head irregularly corrugated; frons armed with three projections; antennal shelf relatively large, sharply margined posteriorly; eye orbit often bordered by depression or raised keels; propodeum remarkably short and small, steeply sloping down.

DESCRIPTION ( $q$ ): HEAD. Head subangular, hypognathous, frons armed with three projections, entire surface of head irregularly corrugated, face distinctly higher than wide, sometimes with median longitudinal keel; eye rather large, higher than wide, more or less tapering ventrally, orbit often bordered by depression or raised keels; ommatidia usually large; ocelli normal; mandible bidentate, with lower tooth longer; palpal formula 5-2; oral carina developed, gena and postgena glabrous; postgenal cushion not developed; cheek in frontal view nonangular but distinctly bulging; hypostomal bridge moderately developed; occipital flange rather reduced; antennal shelf relatively large sharply margined posteriorly; antenna 12-segmented, clava multisegmented (6 segments), semiabrupt, cylindrical, clavomeres slightly to clearly transverse, subrectangular, noncompact, A12 slightly enlarged; A1 elongate, cylindrical, rounded apically. MESOSOMA. Mesosoma moderately to distinctly higher than wide; pronotum anteromedially with moderate to strong shoulders; epomium moderately to strongly developed; propleuron and anterior sides of pronotum without foamy structures or cushions of hairs; mesoscutum moderately elongate, parapsidal lines sometimes developed, mesoscutum convex in lateral view; scutellum distinctly trapezoidal, anterior scutellar pit rather deep, rarely with longitudinal keels on bottom, shorter than scutellar disc; scutellar disc subcircular, with median longitudinal keel present or absent, with lateral keels more or less developed; axillar depression relatively small; axilla rounded posteriorly; mesopleuron rather flat, moderately concave, submedian oblique line well developed, lower portion of mesopleuron (between fore and medial coxa) with zone of matte granular sculpture, upper part of mesopleuron smooth and shining; dorsellum well developed, with three longitudinal keels; metapleuron almost glabrous, rugulose, with deep depression anterodorsally; propodeum remarkably short and small, steeply sloping down, median keel and plica moderately to strongly developed; wings primarily developed, forewing distinctly longer than body, clear or slightly infuscate, stigmal vein moderately to distinctly elongate; wings may be absent in some individuals (alectomy); legs distinctly strong, femora and tibiae nonclavate, cylindrical, tarsi, especially fore and middle legs, very short, strongly compressed, almost foliaceous; apex of anterior tibia without specialized spine dorsally; METASOMA. Petiole in dorsal view distinctly elongate, without longitudinal keels, in lateral view (2 species) strongly compressed, with strong ventral keel, rarely ( 1 species) cylindrical; metasoma past petiole in lateral view only moderately convex (1 species) or flat, entire syntergite with scattered semidecumbent bristles, syntergite posteriorly partly sculptured (2 species) or entirely smooth (1 species); specialized spot on S2 distinctly remote from anterior margin of $\mathrm{S} 2$.

ReCOGNITION AND Relationships: Philolestoides is distinct among ecitophilic genera because of the rough corrugated surface of head and orbit of eye bordered by depression or raised keels. Two of the three species studied show highly modified petiole, strongly compressed, and with raised keel ventrally. The third species from Banhados (Brazil) has 
plain cylindrical petiole. Philolestoides can be compared with Notoxoides, Mimopria, and Ecitovagus primarily because of armed frons and structure of antennal shelf. From Notoxoides it differs by absence of horn on pronotum; from Mimopria by short high propodeum; and from Ecitovagus by structure of propodeum and absence of hump on mesoscutum.

MALE: Unknown.

DisTRIBUTION: We studied three species collected in lowland Brazil.

Biology: Philolestoides wasmanni Ferrière is associated with Neivamyrmex legionis (Smith) (Loiácono, 1981). The species from Banhados (CNCI) was collected by light trap. Absence of wings is reported in P. wasmanni (Ferrière, 1929).

\section{Platymischus Westwood}

Figures 90, 91

Platymischus Westwood, 1832: 128.

Planopriella Kieffer, 1912: 4, 48. Synonymized by Pschorn-Walcher, 1957: 58-88.

DiAgNosis $(q \hat{\jmath})$ : Small-sized individuals (1-2 mm); body color dark brown to black with lighter appendages, body predominantly smooth, with scattered pilosity including entire syntergite, no distinct cushions of hairs but dense pilosity (especially on propodeum and petiole); foamy structures not developed; head in dorsal and lateral view distinctly elongate, frons and antennal shelf projecting forward; eyes remarkably small; ocelli absent; female clava nonabrupt, 4-segmented; male A1 remarkably swollen subtriangular and concave ventrally, A3 modified as sex segment; wings entirely absent; apex of anterior tibia with strong spine dorsally.

DESCRIPTION ( $q$ o ): HEAD. Head in dorsal view distinctly elongate, subpentagonal; frons unarmed; antennal shelf strongly projecting forward, not margined posteriorly; eye remarkably small, projecting laterally; ocelli absent; head in lateral view longer than high, frons and antennal shelf projecting forward; oral carina not developed; postgenal cushion absent; occiput rounded, not steplike, occipital flange reduced to rim; head in frontal view with face slightly wider than high; mandible large, bidentate; epistomal sulcus well impressed; malar sulcus and ten- torial pits absent; hypostomal bridge developed; palpi very short, formula appearing 2: 1; female antenna 12-segmented, A1 long, cylindrical, clava nonabrupt and 4-segmented; male antenna 14-segmented, A1 remarkably swollen, subtriangular and concave ventrally, A3 modified as sex segment, large, with apical projection ventrally, A4-A13 subcircular, with short nonverticillate hairs, A14 moderately elongate. MESOSOMA. Pronotum in dorsal view moderately developed, pronotal shoulders not developed, anterior margin of pronotum and propleuron with fine dense pilosity; sides of pronotum flat, epomium not developed; mesoscutum flattened dorsally, with no sulci or lines; transscutal articulation present but fine; tegula strongly reduced; scutellum subrectangular, flattened, without pits; axilla and axillar depression absent; mesopleuron flat, submedian oblique line shallow, rudimentary; epicnemial pit and sternaulus absent; dorsellum absent; metapleuron entirely covered by dense silvery pilosity; propodeum rather large, flattened dorsally, in lateral view propodeum in same level of mesoscutum, medial keel and plica absent, posterior margin and posterolateral corners of propodeum rounded, not projecting, sides of propodeum with dense pilosity; wings entirely absent; legs short and stout, especially all femora; apex of anterior tibia with strong spine dorsally, male forebasitarsus remarkably expanded distally; tarsi of all legs cylindrical, not compressed. METASOMA. Petiole in dorsal view subquadrate, slightly wider than long, densely hairy, without longitudinal keels, in lateral view petiole slightly higher than anterior margin of syntergite; anterior margin of syntergite wider than petiole; entire syntergite and S2 with dense semierect pilosity; anterior margin of S2 broadly excavate and with dense pilosity; apex of metasoma in female with only short point.

RECOGNITION AND RELATIONSHIPS: In the male sex, Platymischus is readily distinguished from Trichopria largely because of the specialized shape of $\mathrm{A} 1$ and the position of sex segment on A3; also, the expanded forebasitarsus is unique in Platymischus. However, in female sex, Platymischus is rather difficult to separate from some apterous members of Trichopria; the elongate and 
somewhat flattened subpentagonal head with small but projecting eyes in Platymischus is the main distinguishing character between the two genera.

Distribution: The only known species, Platymischus dilatatus Westwood, is amphiAtlantic in the Northern Hemisphere (Sweden, England, Germany, Netherlands, France, Canada, USA). In 1978, Dr. S. Marshall (University of Guelph, Canada) discovered this species in wrack beds on shores of New Brunswick (St. Andrews). We also examined specimens from the shores of Maine and New Hampshire (USA).

BIOLOGY: Specialized inhabitant of wrack beds on rocky shores in the intertidal zone. Hosts in Europe are kelp-eating flies (Diptera) of the family Coelopidae (e.g., Coelopa Meigen) (Baudoin, 1949, 1952), and Sepsidae (Orygma luctuosa Meigen) (Backlund, 1945; Nixon, 1980).

\section{Psychopria, new genus}

Figures 92, 93, 94a, 94

DiAgnosis $(90)$ : Small to very smallsized $(0.7-1.5 \mathrm{~mm})$ gracile individuals with remarkably elongate appendages; body usually dark to light brown, predominantly smooth, remarkably hairy, either with long semidecumbent bristles and/or dense minute appressed pilosity at least on head, sometimes also on meso- and metasoma, cushions of hairs absent, foamy structures present on propleuron, sometimes on metasternum, axillar depressions, and posterolaterally on petiole; head subglobose, moderately wider than long; antennal shelf not developed, toruli usually wide apart, usually closer to inner orbit than to one another, not connected by carina; hypostomal bridge reduced to narrow septum; wings remarkably long and narrow, almost paddle-shaped, marginal cilia extremely long, subequal to wing width, frenal gutter distinctly angularly projecting; foretibia with distinct specialized spine dorsally; apical tarsomere distinctly enlarged with strong claws, especially in females.

DESCRIPTION ( $q$ $\delta$ ): HEAD. Head in dorsal view subglobose, moderately wider than long, frons unarmed, occipital flange narrow, complete; antennal shelf not developed, toruli usually wide apart, usually closer to in- ner orbit than to one another, not connected by carina; ocelli normal; head in lateral view with torulus distinctly in upper level of eye; eye relatively small, subcircular, ommatidia relatively large; oral carina not developed; postgenal cushion absent; malar space relatively large, subequal to eye height; epistomal sulcus slightly indicated basally; malar sulcus indicated at most as shallow declivity; labrum narrowly exposed; mandible bidentate, not projecting, clasped; hypostomal bridge reduced to narrow septum; palpal formula 5:2; female antenna 11-segmented, long and slender, with all segments distinctly elongate, clava usually weakly defined to almost absent, rarely 1-segmented (A11), A11 largest, with or without pit ventrally; male antenna 14-segmented, remarkably long and slender, with short to long nonverticillate pilosity, A4 at most moderately arcuate, without longitudinal keel. MESOSOMA. Pronotum in dorsal view almost invisible except for well developed cervical part, shoulders entirely absent, sides of pronotum almost flat, with no hairy cushion but sometimes with small clusters of foamy structures along anterior margins; epomium not developed; mesoscutum about as long as wide, moderately to considerably convex; parapsidal lines and anterior parallel lines not developed; humeral and suprahumeral sulci not developed; anterior scutellar pit small and shallow, sometimes reduced to two narrow deep slits located at sides or eventually absent, pit distinctly shorter than scutellar disc; scutellar disc only moderately convex, subrectangular, without median keel, with sides rounded, with no lateral or posterior pits; posterior margin of axilla rounded; axillar depression small; mesopleuron moderately convex, median oblique depression almost inconspicuous; sternaulus absent; longitudinal keels on dorsellum weakly developed or absent; propodeum with median keel usually moderately developed, keel rarely raised in anterior part, plica moderately developed; metapleuron and side of propodeum only sparsely hairy or glabrous; metasternum sometimes with foamy structures; forewing remarkably long and narrow, almost paddle-shaped, largely surpassing tip of metasoma, marginal cilia extremely long, subequal to wing width, frenal gutter distinctly angularly projecting, 
marginal vein distinctly elongate, wedgeshaped, stigmal vein not developed, basal vein indicated sometimes by nebulous streak; hind wing extremely narrow, lanceolate, with marginal cilia several times longer than wing width; legs generally long and slender, femora medially and tibiae distally clavate; apex of foretibia with distinct specialized spine dorsally; tarsi long, cylindrical, noncompressed, apical tarsomere distinctly enlarged with strong claws, especially in females. METASOMA. Petiole moderately to distinctly elongate, cylindrical, with fine rugulosity, rarely with longitudinal keels, partly hairy, and usually with foamy structures posterolaterally; metasoma past petiole remarkably short, only slightly wider than long, subcampanulate; anterior margin of syntergite only slightly wider than width of petiole, not flexed or excised, not notched medially, with dense appressed micropilosity or almost glabrous; S2 anteriorly without hairy depressions, never humplike projecting forward, and without specialized spot; apex of metasoma shortly conical in female.

TyPE SPECIES: Psychopria hoguei, new species (described below), by present designation.

ReCognition and Relationships: Psychopria is here classified in the tribe Diapriini. We consider it an apomorphic offshoot of Trichopria, s.l., that is highly adapted for aquatic life. The shape of the legs, especially the strong apical tarsus and strong claws, the narrow paddle-shaped wings with angular frenal gutter as well as the specialized body pilosity are interpreted as adaptations to or for aquatic habitats. Psychopria is easily distinguished in the Trichopria complex by the widely spaced toruli, the absence of a sharp antennal ledge between them, and by the strong reduction of the hypostomal bridge. The specialized dense pilosity of the body of Psychopria is also unique in the Diapriini.

ETYMOLOGY: From psycho (reference to Psychodidae) and pria ("little wasp"); the gender is feminine.

DistRIBUTION: To date, we examined about 20 species from southern Mexico to Bolivia and Brazil including three species from the Antilles (Cuba, Dominica, Hispaniola) (CNCI). Recently an undescribed species was collected in creeks in Arizona.
BIology: Psychopria hoguei was reared from pupae of Maruina sp. (Diptera; Psychodidae) collected from the lowland rivers in Costa Rica (Hogue, 1973). Dr. L. Quate (Poway, CA, USA) kindly supplied several species of Psychopria reared from Maruina spp. in Central America. All other species were collected in the closest vicinity of running waters (yellow pan traps in creek beds), both in the lowlands and in higher elevations. It is highly conceivable that all members of Psychopria are associated with Psychodidae.

\section{Psychopria hoguei, new species}

Figures 92, 93, 94a, 94

DESCRIPTION: Holotype, ô: Length 1.4 $\mathrm{mm}$; body uniformly dark brown, with legs, antennae and especially mandibles slightly lighter; wings uniformly infuscate, forewing with basal vein indicated as nebulous arc. HEAD. Head in dorsal view slightly wider than long (29:25); frons, vertex, and occiput with scattered long semidecumbent bristles; temple behind eye subequal to eye length; space between inner rims of toruli larger than distance between outer rim of torulus and inner orbit of eye $(6: 4)$; head in lateral view higher than long (29:25), eye slightly higher than long (13:11); eye height: malar space (13:11); postgena with dense, short, semiappressed pilosity but no cushion of hairs; head in frontal view with frons covered with dense, semiappressed pilosity as on postgena; malar sulcus indicated at most as shallow declivity; antenna longer than body, all segments narrow and slender, covered with dense short semidecumbent hairs, hairs subequal to width of antennomere; A1 slightly compressed and arcuate in basal third; A4 distinctly shorter than A3, only moderately emarginate in proximal two-thirds; antennomeres in relative proportions (26:4), (10: $3.5)$, (23:2.5), (14:2.5), (14:2.5), (13:2.5), (12:2.5), (12:2.5), (10:2.5), (10:2.5), (9:2.5), $(9: 2.5),(8: 2.5),(10: 2.5)$. MESOSOMA. Mesosoma distinctly longer than wide (61:34), mesoscutum and scutellum with few long semidecumbent bristles but no micropilosity, smooth and highly shining; anterior scutellar pit shallow, slightly transverse and better imprinted in posterolateral corners; axillar depression with small cluster of foamy struc- 
tures; anterolateral corner of pronotum (posterad cervix) with short transverse carina and patch of granular microsculpture; propleuron with large cushion of foamy structures; mesopleuron glabrous, except for ventral portion in between coxae; metapleuron smooth in anterior part, rugulose and glabrous in posterior part; metasternum (between meso and metacoxa) with large cluster of foamy structures; propodeum dorsally and laterally, rugulose with fine appressed pilosity, median keel and plica weakly developed; posterior margin of propodeum arcuate; propodeal nucha short, smooth and shining; forewing maximum width larger than longest marginal cilia (30:20); basal vein nebulous, strongly infuscate; foreleg tibial spur unusually wide and strong. METASOMA. Petiole distinctly elongate (15:9), finely rugulose punctate, with scattered, semierect bristles, bristles denser at sides and with two smaller clusters of foamy structures posterolaterally, anterior margin of petiole sharply rimlike; metasoma past petiole only slightly wider than long (45: 34 ), syntergite with no micropilosity, almost glabrous, with only few semierect bristles, metasoma ventrally with more abundant pilosity.

FEMALE: Unknown.

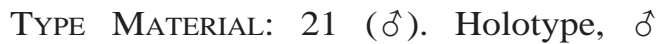
(LACM), COSTA RICA, Provincia San José, Rio Union at Pan American Highway, 22 km SE S. Isidro (nr. Santa Ana), 530 m, May 22, 1972, C.L. Hogue. Paratypes (CNCI no. 22461), 20 t with same data as holotype (LACM, CNCI, MIZA, and INBIO).

ETYMOLOGY: The species is named in honor of the late Dr. Charles Hogue, who collected the type series and made original observations on the biology of the species (Hogue, 1973).

Distribution: Costa Rica.

BIOLOGY: The type series was reared from aquatic pupae of Maruina sp. (Diptera, Psychodidae). Hogue (1973) observed adult wasps crawling on the surface of emergent boulders, apparently in search of the host.

VARIATION: The only variation in the type series is in the body length, $1.3-1.6 \mathrm{~mm}$.

\section{Szelenyiopria Fabritius Figure 96}

Szelenyiopria Fabritius, 1974: 54.

Gymnopria Loiácono, 1987: 130. NEW SYNONYMY.

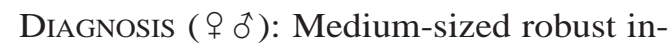
dividuals $(2-3 \mathrm{~mm})$; body predominantly brown to brownish black, legs and antennae mostly lighter color; body predominantly smooth and shining, sometimes with patches of coriaceous sculpture, rarely with rough rugulose sculpture on entire mesosoma, or rarely head and mesosoma matte with fine microsculpture; entire body including legs with specialized setae, setae either long, straight, sparse, light, distinctly truncate apically, or setae shorter, flattened, and tightly appressed to body; cushions of hairs present, foamy structures absent; female antenna 11-segmented, in one undescribed species 12-segmented, clava strong, 3- or 4-segmented, spindle-shaped, clavomeres semicompact, subrectangular; propodeum strongly developed, posterolateral corners strongly raised, posterior margin deeply excavate medially, plica indistinct.

DESCRIPTION ( + †): HEAD. Head in dorsal view subglobular; frons unarmed; antennal shelf not margined posteriorly; temple behind eye relatively long, gradually rounded; head in lateral view with torulus in upper half of eye; eye small, ovoid, higher than half head height, posterior margin rounded; ommatidia relatively small, not convex; ocellus distinctly larger than ommatidium; oral carina moderate; postgenal cushion strongly developed, rarely rudimentary; occipital flange rudimentary; head in frontal view with mandible bidentate, lower tooth slightly longer; head in ventral view with hypostomal bridge very narrow; palpal formula 5-2; female antenna 11-segmented, in one undescribed species 12-segmented, clava strong, 3or 4-segmented, spindle-shaped, clavomeres semicompact subrectangular, with three or four clavomeres flattened ventrally; apical segment (A11 or A12) subconical, longer than preceding clavomere; A1 long, cylindrical, unarmed apically; male antenna 14segmented, relatively short and strong; A3 and A4 distinctly separated, A4 not sexually modified, A4-A13 distally knotted with one row of verticillate bristles, antennomeres relatively short and robust; A7-A12 without specialized brushes. MESOSOMA. Mesosoma robust, about as wide as high; pronotum in dorsal view moderately developed, pronotal shoulders not developed; sides of pron- 
otum without epomium, generally with massive hairy cushion anterodorsally, cushion rarely rudimentary; propleuron with cushion or scattered hairs; mesoscutum as long as wide, parapsidal and anterior parallel, lines at most rudimentary, rarely anterior parallel lines strongly developed; anterior scutellar pit large, rather deep, slightly transverse, sometimes with fine longitudinal keels on bottom, only slightly smaller than scutellar disc; scutellar disc moderately convex, at most with moderate longitudinal keel, lateral keels at most moderately developed; axilla smaller than scutellar pit; posterior margin of axilla moderately rounded; axillar depression relatively large but shallow, glabrous or with dense fine hairs; mesopleuron moderately convex, oblique horizontal line rudimentary; dorsellum well developed, with three keels; metapleuron coarsely rugulose, often densely hairy; propodeum strongly developed, rather long, roughly rugulose, median keel only moderately produced anteriorly, rarely keel more raised but not pointed or curved backward, posterolateral corners of propodeum strongly raised, posterior margin deeply excavate medially, plica indistinct; forewing moderately long, slightly glassy, stigmal vein moderately developed; legs with long, straight, sparse, light setae, setae distinctly truncate apically; tarsi moderately compressed. METASOMA. Petiole robust, slightly elongate, almost quadrate, cylindrical, with longitudinal rugulosity, entire surface with abundant appressed pilosity; metasoma past petiole in dorsal view broadly spindlelike, pointed apically in female, with sparse specialized setae; metasoma in lateral view only slightly convex, more convex ventrally; specialized spot on S2 not visible, anterior margin of S2 with narrow transparent rim.

ReCognition and Relationships: Members of Szelenyiopria share the following character states: female antenna with massive, nonabrupt, spindlelike 3- to 4-segmented clava, clavomeres distinctly flattened ventrally and the rough rugulose propodeum with strongly projecting posterolateral corners. The most important apomorphic feature of Szelenyiopria is the presence on entire body of specialized straight setae, truncate apically; similar setae occur in members of ecitophilic genus Mimopria. Szelenyiopria belongs to Acanthopria complex, as exemplified by structure of derived female antenna, however, the latter two genera differ in male antenna, A3 fused with A4 in Acanthopria and separated in Szelenyiopria. Females of Szelenyiopria share habitus of metasoma with Leucopria, but lack the specialized leucose spot at apex. Gymnopria is presently considered junior synonym of Szelenyiopria; we compared specimens identified by Loiácono (CNCI) with the holotype of Szelenyiopria reichenspergeri (Ferrière) (MNHG). Loiácono and Margaría (2000) described seven new species from Brazil; they prefer to recognize Gymnopria as an independent genus.

DisTRIBUTION: Wide distribution from $\mathrm{Ar}$ gentina to Guatemala (specimens in CNCI).

BIOLOGY: Szelenyiopria lucens (Loiácono), new combination, is the first member of the tribe Diapriini in the New World positively reared from ants. Loiácono (1987) reports up to three wasps per mature larva of Acromyrmex ambiguus (Emery) (Formicidae: Attini). Members of Szelenyiopria show no specialized structures known among other myrmecophilic Diapriini; we assume that the specialized setae with truncate apices are the outlet of chemical substances.

\section{Szelenyisca Masner \\ Figure 95}

\section{Szelenyisca Masner, 1974: 109.}

Diagnosis ( + ): Body small (1.7 mm), light brown, predominantly smooth and shining, relatively glabrous, with sparse pilosity and setigerous punctures, foamy structures present; head unusually large, vertex highly topped; anterior margin of antennal shelf medially rounded; A1 dilated into flat racquetshaped segment, A2 inserted in upper twothirds of A1, i.e., apical third of A1 forms broad flat horn above insertion of A2; antenna highly specialized, 11-segmented, short, A2-A11 subequal in length to A1, clava 6segmented, massive, nonabrupt, subcompact, A11 larger than A10.

DESCRIPTION ( $q$ ): HEAD. Head in dorsal view large, subglobular, transverse, wider than mesosoma; frons unarmed, with scattered, large punctures; antennal shelf very 
shallow, unmargined posteriorly, anterior margin medially rounded; temple rounded, broadly receding; head in lateral view large, higher than long, with vertex highly topped; torulus in level of lower orbit; eye relatively short, distinctly higher than long, high oval, anterior and posterior margins almost parallel, ommatidia relatively small and slightly convex; oral carina minute; postgenal cushion small; occipital flange rudimentary; head in frontal view with frons longer than face, with deep punctures at sides; mandible bidentate, upper tooth truncate with minute incision at meson; palpal formula 5-2(!); antenna highly specialized, 11-segmented, short, A2-A11 combined subequal in length to A1, clava 6-segmented, massive, nonabrupt, subcompact, A11 larger than A10; A5-A10 broadly transverse; A1 dilated into flat racquet-shaped segment, A2 inserted in upper two-thirds of A1, i.e., apical third of A1 forms broad flat horn above insertion of A2. MESOSOMA. Mesosoma relatively short and high, pronotum in dorsal view moderately developed, pronotal shoulders not developed, side of pronotum convex, epomium absent, anterior corner of pronotum with abundant foamy structures; propleuron with denser hairs and some foamy structures; mesoscutum wider than long, considerably convex, parapsidal and anterior parallel lines not developed, mesoscutum with row of setigerous punctures in notaular region; anterior scutellar pit very large, rather deep, transversely oval, distinctly larger than axilla, separated from axillar depression by narrow transparent septum, pit subequal in size to scutellar disc; scutellar disc transverse, subrectangular, highly convex, with well developed median keel, with sharp lateral keels; posterior margin of axilla sharp; axillar depression relatively large, deep, with abundant foamy structures and some fine pilosity; mesopleuron moderately convex, median oblique line moderately developed; dorsellum well developed, with three distinct keels; metapleuron coarsely rugose, with only sparse pilosity; propodeum moderately elongate, plical area almost glabrous, median propodeal keel moderately developed but abruptly rising anteriorly into elevated spatuliform process; plica well developed, posterior margin of propodeum moderately con- cave; forewing relatively broad, with moderately glassy appearance, slightly infuscate, submarginal vein curved, stigmal vein relatively well developed; legs relatively short and stout, hind femur strongly clavate, tibiae moderately clavate, tarsi not compressed. METASOMA. Petiole cylindrical, only slightly longer than wide, with irregular longitudinal keels and scattered pilosity; metasoma past petiole relatively short and broad, shorter than mesosoma, glabrous; syntergite in lateral view glabrous, only slightly convex; terga past syntergite partially retracted, not visible in dorsal view; anterior margin of S2 with semicircular flexed rim; specialized spot not developed.

RECOGNITION AND Relationships: Szelenyisca is easily recognized by the unique structure of A1 and articulation with A2, furthermore by the large and highly topped head. Szelenyisca belongs to the complex of genera around Acanthopria and is considered an apomorphic derivative of the latter. The male is unknown.

Distribution: The only known species, $S$. miricornis Masner, occurs in Brazil and Venezuela (García, 2000); an undescribed species is known to us from Panama.

Biology: Host unknown. The unusual size of the head and structure of A1 may indicate a specialized behavior or host association.

\section{Townesella Huggert and Masner Figure 98}

Townesella Huggert and Masner, 1983: 67-69.

Diagnosis ( $q$ ) Small-sized individuals $(1.7 \mathrm{~mm})$; body honey yellow, predominantly smooth and shining, with scattered long, semidecumbent setae; foamy structures and cushions of hairs not developed; head subhexagonal, with at least posterior ocelli outside ocular zone; eye in lateral view distinctly shorter than postgena; antenna 11-segmented, A11 distinctly larger than A10; metapleuron almost smooth; propodeum posterolaterally with transparent bladelike laminae; petiole in dorsal view subcampanulate, with posterior margin sharp.

DESCRIPTION ( $q$ ): HEAD. Head in dorsal view slightly longer than wide, subhexagonal; temple straight but somewhat convergent posteriorly, temple behind eye slightly longer 
than length of eye, with small area of granular sculpture appearing as minute sharp points; antennal shelf small, not margined posteriorly, frons unarmed; at least posterior ocelli outside ocular zone; head in lateral view with level of torulus in lower half of eye; face as high as wide, with clypeus not clearly indicated, relatively small, subcircular; eye height shorter than half of head height, posterior orbit of eye straight, ommatidia large, highly convex, raspberry-like, eye considerably shorter than postgena, eye only slightly higher than malar space; head in frontal view mandible bidentate, lower tooth sharp and much longer than upper tooth; palpal formula 3-2, palpi short; oral carina fine; head in ventral view with hypostomal bridge well developed; occipital flange absent; antenna 11-segmented without differentiated clava, with A4 to A10 subquadratic, closely approximated, antennomeres progressively enlarged, A11 largest. MESOSOMA. Mesosoma higher than wide; pronotal shoulders distinctly prominent, rounded, with delicate granular sculpture; mesoscutum elongate, in lateral view only moderately convex, without anterior parallel and parapsidal lines; anterior scutellar pit moderate, shorter than scutellar disc, subrectangular, rather shallow; scutellar disc subquadratic, moderately convex, without median longitudinal keel, with lateral keels moderately developed; posterior margin of axilla roundly sloping down, axillar depression small but deep; mesopleuron rather flat, with median oblique line well developed; dorsellum weakly developed, with three longitudinal keels; metapleuron almost smooth, with delicate microsculpture; propodeum short, with sharp prominent median keel and with prominent bladelike laminae posterolaterally; plica moderately developed; forewing primarily developed, elongate, not infuscate, submarginal vein short, slightly exceeding basal one-fourth and closely paralleling front margin of wing, basal vein not indicated; legs relatively long and strong, femur medially incrassate, tibia cylindrical, with long and abundant pilosity, tarsi distinctly compressed, much higher than wide, hind coxa rather large, broadest in basal third, gradually tapering to apex; apex of anterior tibia without specialized spine dorsally. METASOMA. Petiole in dorsal view sub- campanulate, only slightly longer than wide, with posterior margin sharp and slightly concave; metasoma past petiole short, only slightly longer than wide, in lateral view only slightly convex dorsally and ventrally; syntergite with evenly scattered semidecumbent setae; S2 basally with strong semilunar transparent inner apodeme.

RECOGNITION AND RELATIONSHIPS: Huggert and Masner (1983) compared Townesella with Myrmecopria mainly because of shared cephalic characters such as elongate head, long temples, and ocellar triangle outside ocular zone. Townesella can be easily distinguished from Myrmecopria by temples converging toward occiput, with head broadest across eyes, frons unarmed, antennal shelf unmargined posteriorly, and by presence of bladelike laminae posterolaterally on propodeum. Unlike in Myrmecopria pronotal shoulders are angularly protruding and tibial apices are not projecting in Townesella. General sculpture of body of Townesella is smooth, compared with rugulose body of Myrmecopria.

MALE: Unknown.

Distribution: Only one species, Townesella marjoriae Huggert and Masner, is known from the Sonoran region of North America.

Biology: Unknown; several females were caught in light traps in semidesert habitats. The light body color and remarkably raspberry eyes may indicate nocturnal habits of Townesella, presumably associated with ants.

\section{Trichopria Ashmead} Figure 99

Trichopria Ashmead, 1893: 407, 431.

Ashmeadopria Kieffer, 1912: 8, 10, 59. Synonymized by Muesebeck and Walkley, 1951: 1420 pp.

Phaenopria Ashmead, 1893: 40, 436. Synonymized by Sundholm, 1960: 215-223.

Planopria Kieffer, 1906: 19. Synonymized by Kieffer, 1912: 75 pp.

Orthopria Kieffer, 1911: 983, 984. Synonymized by Kieffer, 1912: 75 pp.

Diagnosis ( $q$ $\delta$ ): Small to medium-sized individuals (1-3.5 mm); body color variable, from deep black to pale yellow, body predominantly smooth and glabrous, usually with strong cushions of hairs and some 
foamy structures; frons unarmed; occiput rounded, never carinate or steplike; female clava usually gradually incrassate toward apex, nonabrupt, clavomeres clearly separated, generally subspherical to beadlike, apical segment ventrally often with specialized pit; plica of propodeum generally weakly developed, area between plica and keel usually covered with pilosity; apex of anterior tibia with long, slender spine dorsally.

DESCRIPTION ( $q$ o $)$ : HEAD. Head in dorsal view usually globular, rarely subpentagonal or elongate, frons unarmed; antennal shelf usually moderate, not margined posteriorly; head in lateral view with torulus in various level of eye; eye generally subcircular, variable in size, posterior margin never sinuate; ommatidia relatively small and flat, never raspberry-like; ocelli normal in winged individuals, absent or rudimentary in shortwinged or wingless individuals; oral carina moderately developed; postgenal cushion usually strongly developed, rarely replaced by sparse pilosity or very rarely postgena almost glabrous; occiput rounded, never carinate or steplike, occipital flange moderate; head in frontal view with face usually as wide as high or transverse, usually with scattered setigerous punctures; mandible generally bidentate, rarely strongly projecting or tridentate; clypeus usually with deep transverse sulcus above anterior margin, epistomal sulcus rarely impressed; tentorial pit not developed; malar sulcus very rarely developed or indicated by shallow declivity; head in ventral view with hypostomal bridge well developed; papal formula 5-2 or 4-2, rarely 3-2; female antenna generally 12-segmented, rarely 11-segmented, predominantly clavate, clava usually gradually incrassate toward apex, nonabrupt, rarely semiabrupt, usually 3-4-segmented, rarely multisegmented (5-6 segments), clavomeres clearly separated, generally subspherical to beadlike, apical segment generally largest, usually flattened ventrally, often with specialized shallow pit; male antenna highly variable, A3 to A14 usually elongate-cylindrical to elongate-knotted, rarely beadlike, with short hairs or long bristles, bristles often arranged in whorls, A4 usually sexually modified, enlarged, curved, with keel, rarely A3 or A3 and A4 modified, rarely no segment modified; specialized brushes often present on A7-A8, A8-A9, or only on A8; A1 cylindrical, usually without longitudinal keels, unarmed apically, in males distinctly longer than A3. MESOSOMA. Pronotum in dorsal view only moderately developed, pronotal shoulders at most rudimentary, sides of pronotum flat, epomium not developed, anterior margin or pronotum usually with dense hairy cushion, rarely interspersed with foamy structures; propleuron usually densely hairy or with hairy cushion, rarely with foamy structures; mesoscutum generally slightly elongate, at most moderately convex, with no sulci, lines or depressions, with sparse semierect long hairs; anterior scutellar pit of various shapes, generally shallow, from large, subcircular or transverse subrectangular to small, or pit completely absent, or median part of pit elevated leaving two lateral separate depressions or pit bisected by median scutellar keel or narrow septum, pit rarely with fine longitudinal striae; scutellar disc usually sharply subrectangular, generally flat or with elevated median keel, very rarely armed or with transverse keel; axilla generally well developed, with sharp posterior margins or axilla almost fused with scutellar disc in species with no anterior scutellar pit; axillar depression moderate, with pilosity, rarely with foamy structures; mesopleuron rather flat, trapezoidal, smooth, shining and glabrous, very rarely with fine horizontal striae, submedian oblique line at most rudimentary, sternaulus not developed; dorsellum generally with three keels, median keel usually strongest; metapleuron entirely covered by dense silvery appressed pilosity; metasternum often with foamy structures; propodeum elongate, propodeal keel usually well developed, often raised anteriorly, rarely produced into long slender backcurved spine, plica generally weakly developed, area between plica and keel usually covered with pilosity, posterior margin of propodeum only moderately excavate, posterolateral corners not angularly projecting; forewing usually elongate, with abundant microtrichia, very rarely infuscate, basal vein not developed but sometimes wing with dark transverse band below marginal vein, submarginal vein strongly approximated to anterior margin of wing, not distinctly upcurved, reaching approximately basal third 
of wing, marginal vein wedge-shaped, stigmal vein rudimentary; posterior margin (at frenal gutter) nonangular; submarginal vein in hind wing rudimentary, usually present as basal stem and as spot with hamuli; wings shortened or absent in some species (females or females and males); legs generally slender, femora distinctly clavate distally, tibia moderately clavate distally, tarsi not compressed; apex of anterior tibia with long, slender spine dorsally. METASOMA. Petiole usually slightly elongate, rarely strongly elongate or transverse, always cylindrical, usually densely hairy, rarely with foamy structures, sometimes with longitudinal keels; metasoma past petiole generally elongate, of various shapes, apex in female subobtuse, pointed to conical, metasoma predominantly glabrous, rarely with long scattered hairs, smooth and highly shining, very rarely punctate apically; anterior margin of syntergite straight, not flexed or excised; S2 anteriorly without hairy depressions, sometimes with dense pilosity, anterior margin of S2 rarely humplike projecting forward; specialized spot on S2 not developed; apical sternite in female often vomeriform and long-pointed.

RECOGNITION AND RELATIONSHIPS: Trichopria is no doubt the largest genus of the Diapriinae in the New World. The polytypic nature of this genus precludes definition other than by combination of character states (see Diagnosis above). Sundholm (1960) discussed the status of Trichopria and related genera. In the Neotropical region Trichopria is conveniently distinguished from Acanthopria by presence of a specialized spine on the foretibia, as well as by subspherical (nonrectangular) clavomeres in female antenna and A3 and A4 in male antenna clearly separated. Trichopria, s.1., is separated from Diapria rather arbitrarily by the shape of the anterior margin of syntergite and by differences in the structure of female clava. The Nearctic genera Auxopaedeutes and Bruesopria are considered at this moment as specialized derivatives of Trichopria. The Nearctic species of Trichopria are predominantly dark colored in comparison with generally light-colored Neotropical species.

Distribution: Worldwide. Numerous species are known from both Nearctic and Neotropic regions; however, at present only a fragment of actual size of the genus is known, with most species still undescribed. The near absence of Trichopria in Chile is quite notable.

BIOLOGY: Numerous species were reared as solitary or gregarious parasitoids of various Diptera (e.g., Notton, 1991); one undescribed species is known to us as parasitoid of Psephenidae (Coleoptera) (Brown, 1967). Several species were found in ant nests and some are aquatic or semiaquatic in habits.

\section{Turripria, new genus}

Figure 100

Diagnosis ( $q$ ): Small to medium-sized individuals $(1.5-3 \mathrm{~mm})$; body always light-colored, yellowish brown to ferrugineous, body shining but with various degree of sculpture, coriaceous to rugulose, with scattered semidecumbent bristles, hairy cushions not developed, foamy structures present on propleuron or metasternum, usually rudimentary; head with vertex remarkably topped, vertex moderately to extremely elevated above eyes, ocelli consequently very far from inner orbits, OOL unusually long; A11 distinctly larger than A10; mesosoma moderately compressed, distinctly higher than wide; mesopleuron usually with dense horizontal striae; axilla rounded posteriorly; axillar depression rudimentary; propodeum short, highly topped; hind coxa distinctly elongate, cylindrical or conical, subequal to or slightly longer than petiole.

DESCRIPTION ( $q$ ): HEAD. Head with vertex remarkably topped, vertex moderately to extremely elevated above eyes, head hypognathous, frons unarmed, antennal shelf moderately developed, not margined posteriorly, level of torulus below half height of eye; face subquadrate; eye distinctly higher than long, ovoid inverted droplike, ommatidia relatively large and convex, almost raspberry-like; ocelli situated at top of elevated vertex, very far from inner orbit, OOL unusually long; mandible bidentate, palpal formula 5-2; oral carina moderately developed; postgenal cushion not developed; hypostomal bridge distinctly developed; occipital flange moderate to rudimentary; antenna 11-segmented, with nonabrupt multisegmented clava (6-7 segments), clavomeres subquadrate, rarely 
elongate, noncompact, A11 distinctly larger than A10, A1 elongate, usually robust, cylindrical, unarmed apically. MESOSOMA. Mesosoma moderately compressed, distinctly higher than wide; side of pronotum relatively flat, pronotal shoulders not developed, epomium rudimentary; upper propleuron rarely with residual foamy structures; mesoscutum distinctly longer than wide, in lateral view highly convex; anterior parallel and parapsidal lines not developed; scutellum subtrapezoidal, anterior scutellar pit well developed, subrectangular, moderately deep, smooth on bottom, shorter than scutellar disc; scutellar disc subcircular, usually with longitudinal median keel, with lateral keels moderately arched; axilla distinctly rounded posteriorly, sloping roundly down; axillar depression rudimentary; mesopleuron flat, subrectangular, more or less straight ventrally, usually with dense, fine, horizontal striae, submedian oblique line distinctly developed; dorsellum well defined, longitudinal keels rudimentary or present; metapleuron with rough rugulose sculpture, with large deep oval depression anteriorly right behind mesopleuron, with only scattered hairs; deep cleft between dorsellum and propodeum; propodeum relatively short, highly topped, median keel usually well developed, plica rudimentary or absent, posterior margin of propodeum almost straight; forewing primarily present, rather long, usually clear, marginal cilia rather long, stigmal vein moderately developed, basal vein not developed; legs usually relatively short and strong; hind coxa distinctly elongate, cylindrical or conical, subequal in length to or slightly longer than petiole; hind femur widest near middle, all tibiae narrowed basally, tarsi moderately to distinctly compressed; apex of anterior tibia without specialized spine dorsally. METASOMA. Metasoma with petiole slightly longer than wide, robust, subcylindrical, highly convex dorsally, without keels, in lateral view petiole strongly sloping down posteriorly in front of syntergite; metasoma past petiole moderately elongate, ovoid, distinctly pointed apically, only moderately convex dorsally and ventrally, syntergite entirely covered with scattered semidecumbent bristles; anterior margin of S2 entire, specialized spot not visible.

TyPE SPECIES: Turripria woldai, new spe- cies (described below), by present designation.

RECOGNITION AND RELATIONSHIPS: Turripria is remarkable in shape of head, with vertex highly topped and ocelli elevated high above eyes. Turripria shares shape and structure of propodeum with Philolestoides and Asolenopsia; also the shape of eye and distinctly convex ommatidia are shared among the three genera. The males of Turripria are unknown.

ETYMOLOGY: From the Latin turris ("tower"), with reference to the peculiar shape of the head in lateral view, and the suffix pria meaning "little wasp"; the gender is feminine.

MALE: Unknown.

DisTRIBUTION: We studied six species from lowland tropical forests of Panama, Costa Rica, Nicaragua and the Pacific side of Ecuador (material in $\mathrm{CNCI}$ ).

Biology: Biology is not known; however, the color, sculpture, and general habitus of body, raspberry eyes, as well as lytic alectomy lead us to believe that Turripria is associated with ants. Numerous individuals of $T$. woldai, new species, were collected in light traps in Panama with various degrees of lytic alectomy in process; most specimens in CNCI of the above series show various degrees of wing loss.

\section{Turripria woldai, new species}

Figure 100

DESCRIPTION: Holotype, $q$ : Length 1.6 $\mathrm{mm}$; body entirely golden-yellow, eyes distinctly darker; body with scattered semidecumbent pale hairs; wings almost clear. HEAD. Head in dorsal view moderately longer than wide $(37: 31)$, with fine rugulose sculpture; temple behind eye strongly receding, shorter than eye (16:10), temple posteriorly (in front of occipital flange) subangular because of vertical zone of rugulosity descending to postgena; occipital flange moderate, steplike, slightly wider than width of ocellus; eye raspberry-like, ommatidia large and convex, only slightly smaller than ocellus; antennal shelf strongly projecting forward, torulus in level with lower half of eye; head in lateral view higher than long (42:37), with frons and occiput convex, nonconical, 
top of vertex rounded; part of head above upper orbit distinctly shorter than eye height (10:24); postgena narrower than eye length (12:16); eye height malar space $(24: 10)$; eye shorter than head height (24:42); head in frontal view with rugulose sculpture on face, with finer sculpture on frons; antenna relatively short and strong, A1 robust, only three times longer than wide, with rough sculpture; clava indistinctly 6-segmented, with dense decumbent pale pilosity, slightly gradually incrassated toward apex; antennomeres in relative proportions $(30: 9.5),(8.5: 5.5),(10:$ 5), (6.5:6), (6.5:7), (6:8), (7:9), (7:9), (7:9.5), (7:9.5), (17:10). MESOSOMA. Mesosoma in relative proportions length:width:height (55: 30:40); anterodorsal corner of pronotum with rough rugulose sculpture, side of pronotum predominantly sculptured, with irregular wavy horizontal striae and with relatively smaller smooth area anterad spiracle; median lobe of mesoscutum remarkably highly convex, mesoscutum almost smooth laterally, with fine coriaceous sculpture medially; scutellar disc with complete longitudinal median keel; entire mesopleuron with fine dense horizontal sculpture similar to that on sides of pronotum, with extreme ventral lobe almost smooth; metasternum with scattered foamy structures; median propodeal keel sharply pointed anteriorly, plica rudimentary, indicated only anteriorly. METASOMA. Metasoma with petiole in relative proportions length:width:height, (18:13:13), petiole humped dorsally, straight ventrally, with fine rugulose sculpture; metasoma past petiole in proportion length:width:height (63:35:35).

MALE: Unknown.

TyPe MATERIAL: 50 $q$. Holotype, $q$ (CNCI no. 22462), PANAMA, C.Z., Barro Colorado Is., July 2-8 1978, light trap no. 1, H. Wolda. Paratypes, $49 q$ from Barro Colorado Is., C.Z. (Panama), lowland rainforest, collected in light traps, with flight periods in February and July and few individuals collected in May, August and December 1977 and 1978. Paratypes deposited in CNCI, INBC, MIUP, MIZA, NMNH, USNM.

ETYMOLOGY: This new species is named in honor of Mr. Henk Wolda, who collected the type series as well as many other nocturnal Diapriinae in Barro Colorado Island (Panama).
BIOLOGY: Females collected in light traps exhibited lytic alectomy in progress; in many individuals wings were missing or fragile and were detached during mounting.

VARIATION: Minimum variation in total body length, color, and sculpture was observed among the type series.

\section{Xanthopria Brues \\ Figure 102}

\section{Xanthopria Brues, 1915: 9.}

Diagnosis ( 9 ): Small-sized individuals $(1.5 \mathrm{~mm})$, body color ferrugineous, head and mesosoma, including legs and tegula, entirely sculptured, granular-coriaceous; metasoma past petiole smooth, body relatively glabrous with only few appressed golden hairs, no hairy cushions but some parts of body with minute pilosity, foamy structures developed; face in profile straight, almost perpendicular to frons; clypeus rather protruding, deep broad cleft between clypeus and upper margin of mandibles; scutellar disc pillowshaped, convex, median and lateral keels not developed; forewing with only minute microtrichia on disc, marginal cilia entirely absent.

DESCRIPTION ( $q$ ): HEAD. Head subglobular, frons unarmed, antennal shelf moderate, not margined posteriorly, antennal shelf only moderately protruding, level of torulus approximately in lower half of eye; eye relatively large, ovoid, with posterior orbit not sinuate; ocelli relatively small, ommatidia rather large, highly convex, raspberry-like, ommatidium only slightly smaller than ocellus; oral carina not developed, postgenal cushion not developed; occipital flange rudimentary; face in profile straight, almost perpendicular to frons; clypeus rather protruding, deep, broad cleft between clypeus and upper margin of mandible; epistomal and malar sulcus shallow and tentorial pit not developed; hypostomal bridge well developed; palpal formula 4-2; antenna 11-segmented, with nonabrupt 5-6-segmented clava, clavomeres subrectangular, with narrow gaps, A11 larger than A10, A1 cylindrical, unarmed apically. MESOSOMA. Pronotum in dorsal view moderately developed, pronotal shoulder absent, side of pronotum almost flat, epomium not developed, shoulder region 
with massive patch of foamy structures; propleuron with scattered foamy structures; mesoscutum as long as wide, only moderately convex, slightly depressed medially, without sulci or lines; anterior scutellar pit shallow, slightly transverse, without ridges; scutellar disc pillow shape, convex, median and lateral keels not developed; posterior margin of axilla weakly carinate; axillar depression with abundant foamy structures and same appressed pilosity; mesopleuron rather flat, with distinct oblique submedian line; sternaulus not developed; dorsellum moderately developed; keels weakly developed, metapleuron entirely covered with appressed short silvery pilosity; metasternum with foamy structures; propodeum moderately long, median keel produced anteriorly into blunt projection turned backward; plica partly developed, area between plica and keel with dense appressed pilosity; posterior margin of propodeum only moderately excised, rather rimlike-projecting; forewing with only minute microtrichia on disc, marginal cilia entirely absent, submarginal vein moderately upcurved, stigmal vein strongly developed, basal vein not developed; legs rather short and stout, tarsi not compressed. METASOMA. Petiole very short, slightly transverse, cylindrical, with dense fine pilosity, without longitudinal keels; metasoma past petiole only slightly convex; syntergite rather broad anteriorly, smooth, shining, almost glabrous; S2 anteriorly without specialized spot.

RECOGNITION AND RELATIONSHIPS: Among the Neotropical genera with 11-segmented female antenna Xanthopria is recognized by two apomorphies: the deep cleft between clypeus and mandibles and the absence of marginal cilia in forewing. The intense sculpture on head and mesosoma also appears diagnostic for the genus. Brues (1915) described two species, $X$. opaca (type species) and $X$. nitida; after examination of the types (MCZC) we decided to transfer $X$. nitida to Acanthopria (new combination). Xanthopria is interpreted as specialized derivative of Acanthopria.

MALE: Unknown.

Distribution: We examined two specimens of $X$. opaca, the holotype, and a female (CNCI), both from Brazil.

BIOLOGY: Host and habits unknown, but possible association with ants is highly probable.

\section{UNPLACED GENERA}

(Incertae sedis)

Caecopria Masner

Figures 27, 28, 29, 30, 31

Caecopria Masner, 1969b: 314, 323.

Diagnosis $(q \delta)$ : The sexes are almost always strikingly dimorphic and will be treated separately; females are always apterous, almost blind, antlike in habitus; males are predominantly winged, when (rarely) apterous, they superficially resembling females.

Diagnosis ( $q$ ): Minute to small-sized individuals (around $1 \mathrm{~mm}$ ), rarely mediumsized (up to $2 \mathrm{~mm}$ ); body color from yellow to dark brown, antenna and legs distinctly lighter, at least head and often also mesosoma strongly sculptured, granular, or deeply punctate, metasoma past petiole always smooth, body generally hairy but with no hairy cushions or foamy structures; head distinctly opisthognathous; frons almost always serrate laterally (above ocular area); eye reduced to single ommatidium; labrum not exposed; palpi strongly reduced or atrophied, formula $1-0$ or $0-0$; antenna short and strong, 9-10-segmented, with massive, abrupt, 3-segmented clava; mesosoma strongly modified, with sutures in various degree of reduction or sutures completely absent; tarsal formula 5-5-5 or 4-4-4; anterior margin of syntergite usually rimlike, moderately to strongly concave, usually notched medially; S2 almost always with two deep longitudinal grooves.

DiAgnOSIS (winged $\widehat{\jmath}$ ) : Minute to largesized individuals $(0.5-4.5 \mathrm{~mm})$; body color from light yellow to dark brown, head usually strongly sculptured, usually granular, mesosoma partly sculptured, usually punctate, metasoma past petiole always smooth, body predominantly hairy, with no hairy cushions or foamy structures; head distinctly opisthognathous, frons often with serrate ledge above eye, or with transverse ledge in front of ocelli; eye remarkably bulging, large, with long dense hair, ommatidia large and convex, raspberry-like, inner orbits of eyes moderately to strongly converging 
downward, labrum not exposed; palpi generally reduced, palpal formula either 3-2, more frequently $0-0$; antenna 12 -segmented, very rarely 14-segmented; mesosoma relatively short, highly convex dorsally, at least as high as wide, with massive mesothorax and relatively small pronotum and propodeum; wings unusually large and broad, forewing with stigmal vein unusually long, fingerlike, oblique.

Diagnosis (wingless 0 ) : Strikingly similar to female in general habitus; clava heavy but nonabrupt, 3-4-segmented, rarely abruptly 4-segmented, antenna gradually incrassate, 9-10-segmented, A3 usually sexually modified, with sharp keel; tarsal formula 4-4-4.

DESCRIPTION ( $q$ ): HEAD. Head distinctly opisthognathous, in dorsal view slightly to distinctly elongate, frons almost always serrate laterally (above ocular area), serration sometimes continues in complete semicircle on frons, antennal shelf large not margined posteriorly; head in lateral view with antennal shelf strongly projecting, anterior margin of shelf sharp, often bladelike to pointed; eye reduced to single ommatidium, usually strongly convex, rarely ommatidium enlarged; ommatidium positioned in anterodorsal corner of head; ocelli absent; oral carina well developed; occipital flange developed; face relatively long; mandible highly modified, falcate, strongly beaklike-projecting, opisthognathous, bidentate, mandibular condyle deeply arcuate, rimlike; clypeus relatively small, subtriangular, slightly convex, not clearly differentiate from face, tentorial pit large; epistomal and malar sulcus not developed, hypostomal bridge developed, carinate; palpi strongly reduced or atrophied, formula $1-0$ or $0-0$; antenna short and strong, 9-10-segmented, with massive, abrupt, 3segmented clava, A1 long, cylindrical, unarmed apically. MESOSOMA. Mesosoma strongly modified, with sutures in various degrees of reduction or sutures completely absent; pronotum usually strongly developed both dorsally and laterally, rarely separate by suture from mesoscutum, sides of pronotum usually fused with mesopleuron, cervical part strongly developed, pronotal shoulders and epomium not developed; spiracle on pronotum well developed, often strongly projecting; mesoscutum usually fused with pron- otum and scutellum, mesoscutum dorsally usually flat or slightly concave or slightly convex, sloping roundly into pleural region; tegula absent, very rarely rudimentary; mesopleuron usually strongly reduced, indicated by deep sulcus above mid coxa; dorsellum absent; metapleuron relatively large and smooth; propodeum large, horizontal, usually fused with rest of mesosoma or separated by transverse suture, median keel and plica usually not developed, posterior margin of propodeum usually slightly arcuate or with minute notch medially; wings absent; legs short, tibia and femora distinctly clavate, tibial spur formula 1-2-2, coxae generally long and slender, cylindrical, tarsi relatively slender, not compressed, formula 5-5-5 or 4-44. METASOMA. Petiole robust, slightly elongate, usually smooth, rarely with longitudinal keels laterally, with abundant pilosity, in lateral view petiole remarkably arched; metasoma past petiole slightly to moderately elongate, syntergite only slightly convex dorsally, anterior margin of syntergite usually rimlike, moderately to strongly concave, usually notched medially, syntergite usually hairy, pilosity decumbent; following tergites very narrow, apex short-pointed; S2 usually strongly developed anteriorly, pushed ahead of anterior margin of $\mathrm{T} 2$ and partly visible dorsally, S2 almost always with two deep longitudinal grooves, grooves often partly hairy, rarely grooves absent or reaching almost to apex of S2, specialized spot not developed.

DESCRIPTION (winged $₫$ ): HEAD. Head distinctly opisthognathous, frons often with serrate ledge above eye or with transverse ledge in front of ocelli; antennal shelf deep, not margined posteriorly, temples behind eyes strongly receding; head in lateral view with antennal shelf remarkably projecting, level of toruli above middle of the eye; eye remarkably bulging, large, with long dense hairs, ommatidia large and convex, raspberry-like; ocelli unusually large, highly convex; oral carina well developed; occipital flange developed; face distinctly higher than wide, elevated medially, inner orbits of eyes moderately to distinctly converging downward; mandible long falcate, bidentate apically, mandibular condyle deeply arcuate, rimlike; clypeus relatively small, strongly 
convex, subtriangular; tentorial pit large; labrum not exposed; malar sulcus not developed; hypostomal bridge elevated, carinate, foramen magnum roundly sloping down; palpi generally reduced, palpal formula either $3-2$, more frequently $0-0$; antenna 12 -segmented, very rarely 14-segmented, usually threadlike, A4 usually not modified sexually, rarely with sharp keel, with dense scattered pilosity, specialized brushes usually on A8A10 or absent. MESOSOMA. Mesosoma relatively short, highly convex dorsally, at least as high as wide, with massive mesothorax and relatively small pronotum and propodeum; pronotum in dorsal view weakly developed, pronotal shoulders and epomium not developed; mesoscutum strongly convex dorsally, notaulus always complete, often dilated posteriorly, usually not completely contiguous with transscutal articulation, admedian and parapsidal lines and humeral sulci rarely present; scutellum relatively large, anterior scutellar pit of various shapes, deep transverse to subcircular, subbifoveate or shallow, with irregular sculpture, pit always smaller than scutellar disc; scutellar disc large, either sharply margined, subrectangular or pillow-shaped with sides rounded, only moderately convex dorsally, median keel never developed, lateral and posterior pits not developed; axilla with outer margin sharp, bladelike, posterior margin of axilla sharp or rounded, axillar depression large, often almost glabrous; mesopleuron convex, often strongly bulging in lower half; epicnemial pit usually indicated by irregular rugulosity; sternaulus not developed; median oblique line indicated by weak declivity; dorsellum relatively strong, often with three short keels; metapleuron with massive deep hairy depression anterodorsally, rugulose posteriorly; propodeum relatively short, strongly sloping down, median keel either well developed or absent, plica very rarely developed; posterior margin of propodeum rimlike or not developed, nucha partly visible dorsally; wings remarkably large, broad, and long, largely surpassing tip of metasoma, often deeply infuscate, with dense microtrichia, veins strongly darkened, venation in forewing surpassing basal third of wing length, costa usually pale, sometimes pigmented, submarginal vein enclosing very broad costal cell, marginal vein short, stigmal vein remarkably long, fingerlike, oblique, basal vein developed, usually running oblique toward base of marginal vein or rarely almost perpendicular to submarginal vein, but never contiguous with marginal or submarginal veins; posterior portion of median vein often deeply pigmented, joining base of basal vein, other veins sometimes nebulous; hind wing very narrow in basal part, with submarginal vein strongly sclerotized, complete; legs long and slender, femur moderately clavate, tibia cylindrical, tibial spur formula $1-2-2$; tarsi long and slender, cylindrical, formula 5-5-5. METASOMA. Petiole cylindrical, moderately to distinctly elongate, rarely transverse, with abundant pilosity, without longitudinal keels; metasoma past petiole relatively small, anterior margin of syntergite usually rimlike, moderately to strongly concave, usually notched medially, syntergite usually hairy, pilosity decumbent; S2 moderately produced anteriorly, with two longitudinal grooves.

RECOGNITION AND RELATIONSHIPS: Masner (1969b) described only the females of Caecopria. The males were recognized subsequently as both winged and rarely also apterous; they are described here for the first time. Caecopria is perhaps the most dimorphic and polytypic genus of the Diapriidae; we associated the opposite sexes only after much deliberation. The final conclusion was derived from identical structures of head and metasoma, i.e., two parts of body least affected by sexual dimorphism. The wingless males mimicking females were particularly difficult to interpret. Caecopria shares superficial resemblance with some members of the Psilini (Coptera, Psilus) especially in armature of head and structure of mandibles; however, differs principally in shape of the wing and type of wing venation, as well as in the structure of metasoma. The relationship of Caecopria with Doliopria cannot be confirmed, and we also do not recognize the assumed transantarctic relationships of Caecopria with Austropria (Masner, 1969b).

Distribution: Caecopria is restricted to the Neotropical region; three species were described from Brazil (Masner, 1969b). We examined several hundred specimens (CNCI), mostly winged males, representing many new species, from Central and South 
America (Mexico to Brazil) including the Antilles. Members prevail in lowland rainforests, cooler cloud forests, rarely in higher altitudes (Andes of Ecuador up to $3600 \mathrm{~m}$ ). The genus is not known from Chile and Argentina.

Biology: Masner (1969b) assumed Caecopria to be myrmecophilic in habits; this was confirmed by Loiácono (1981) who found two species (females) in a nest of Camponotus rufipes (Fabricius) in Brazil. The senior author recently examined specimens of an undescribed species of Caecopria collected in a nest of leafcutting ants in Trinidad W.I. (CNCI). The winged males of Caecopria are presumably nocturnal in habits, as demonstrated by numerous specimens caught in light traps; the raspberry eyes, general color of body as well as large ocelli support this view. The males are also caught by various techniques; however, the females are found primarily in litter (Berlese). The unusually large wings as well as strongly developed pterothorax of males and the relatively small size of apterous females may suggest aerial transport of females during mating; this strategy is well-known in various groups of Hymenoptera (Evans, 1969).

\section{Calogalesus Kieffer Figure 34}

\section{Calogalesus Kieffer, 1912: 6, 43.}

Diagnosis ( $q \hat{o}$ ): Minute (about $1 \mathrm{~mm}$ ), gracile individuals; body color light to dark brown with appendages slightly lighter; body predominantly smooth and almost glabrous, highly shining with only scattered semierect hairs, with moderate hairy cushions on postgena and anterior margin of pronotum, but no foamy structures; head armed with sharp ledges or points; antennal shelf bladelikeprojecting; labrum exposed, sclerotized, subtriangular; mandible long, beaklike-projecting, almost opisthognathous; oral carina moderately developed, yet blocking lateral movement of mandible; antennal formula 12-14; notaulus percurrent; anterior scutellar pit bifoveate; forewing relatively short and broad, with extremely long marginal cilia; submarginal vein in forewing distinctly remote from foremargin of wing, marginal and stigmal veins subequal in length, almost per- pendicular to one another; metasoma in lateral view distinctly angular between petiole and syntergite; petiole distinctly elongate, in lateral view remarkably arcuate; metasoma past petiole moderately to strongly compressed laterally, apex of metasoma conical in female; segments past syntergite often telescoped; synsternite almost entirely concealed ventrally by sides of syntergite; apical sternite vomeriform; ovipositor valves strongly sclerotized, often extruded apically.

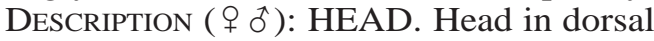
view subglobular, with antennal shelf and toruli strongly projecting, posterolateral corners of shelf sharply pointed; frons (in front of anterior ocellus) with two little sharp points and with sharp longitudinal ledge above upper eye orbit; temple subequal in length to eye; head in lateral view with antennal shelf strongly projecting, level of torulus at midpoint of eye; eye moderately large, ovoid, with ommatidia moderately large; oral carina moderately developed yet blocking lateral movement of mandible; postgena usually moderately developed; posterior margin of occiput not distinctly steplike, occipital flange narrow, with fine crenulae; head in frontal view with face strongly convex medially, depressed near clypeus; clypeus relatively small, highly convex, subtriangular, distinctly longer than wide; epistomal sulcus not developed; labrum exposed, sclerotized, triangular in shape; malar sulcus developed; malar space shorter than height of eye; tentorial pit not developed; mandible long, beaklike, not clasped, parallel, bidentate, projecting backward, almost opisthognathous; palpal formula 5-2; head in ventral view with hypostomal bridge not developed; antennal formula 12-14; A1 relatively long, distinctly compressed basally, apical rim without flaps, not projecting, not excavate ventrally; female antenna without distinct clava, A4-A11 almost beadlike; male A3A13 beadlike, A3 subequal in length to A4, A4 not modified. MESOSOMA. Mesosoma relatively short, usually as wide as high, moderately convex dorsally; prothorax in dorsal view with cervix well developed; pronotal shoulders moderate, rounded; side of pronotum anteriorly with moderate hairy cushion, usually with row of fine crenulae along posterior margin (above forecoxa); 
epomium not developed; spiracle on prothorax relatively large and projecting; mesoscutum distinctly wider than long, moderately convex, with only few scattered semierect hairs; parapsidal and anterior parallel lines not developed, but anterior margin of midlobe of mesoscutum often crenulate; notaulus deep, percurrent, often slightly sinuate, noncrenulate, not dilated posteriorly and not reaching transscutal articulation; humeral sulcus narrow but well developed; suprahumeral sulcus not developed; anterior scutellar pit large, bifoveate; scutellar disc subquadrate, only moderately convex, without median longitudinal keel, with moderate lateral keels; lateral pit very narrow, posterior scutellar pit developed; posterior margin of axilla sharp, overhanging axillar depression; axillar depression relatively large, with scattered pilosity; mesopleuron only slightly convex, mostly smooth and glabrous; median oblique depression relatively deep, especially in anterior part; epicnemial pit and epicnemial carina strongly developed; sternaulus absent; posterior margin of mesopleuron sometimes with rudimentary crenulae or rugulosity, upper margin of mesopleuron (under tegula) with several irregular longitudinal grooves; metanotum moderately developed, dorsellum with three low longitudinal keels; metapleuron rough rugulose, partly hairy; propodeum relatively large but short, roughly rugose, with median keel not developed, keel replaced by longitudinal rugulosity, plica not clearly developed; posterolateral corners of propodeum sometimes bladelike-projecting; nucha extremely short; forewing relatively short and broad, with extremely long marginal cilia, without longitudinal fold or apical excision; costal cell rather broad, costal vein almost absent, rudimentary near tegula; submarginal vein in forewing distinctly remote from foremargin of wing, vein surpassing basal third of wing length; marginal vein remarkably long, stigmal vein distinctly elongate, two veins almost perpendicular to one another, basal and other veins absent; hind wing extremely narrow, almost lanceolate, with tubular submarginal vein; legs moderately elongate, trochanters distinctly elongate, femora and tibiae subclavate in posterior half; apex of femora without flaps. METASOMA. Metasoma distinctly pedunculate, in lateral view distinctly angular between petiole and syntergite; petiole distinctly elongate, in lateral view remarkably arcuate, with irregular rugulosity, without longitudinal carinae, predominantly glabrous, with only few scattered semierect hairs; metasoma past petiole moderately to strongly compressed laterally; anterior margin of syntergite at most slightly arcuate but not notched or excised medially, syntergite without median longitudinal groove; apex of metasoma conical in female; segments past syntergite often telescoped; S2 almost entirely concealed ventrally by sides of syntergite; apical sternite vomeriform.

RECOGNITION AND RELATIONSHIPS: Within the Diapriinae, Calogalesus is considerably isolated taxonomically; however, it is related to the tribe Psilini because of some cephalic character states (e.g., development of labrum, mandible, armature of frons, etc.), but cannot be satisfactorily placed here. The venation of the forewing as well as the structure of the metasoma in general (syntergite, i.e., T2 + T3) make the genus very distinct. Kieffer (1911) wrongly stated the notaulus absent in Calogalesus, an error corrected by Masner (1965). The above diagnosis and description of the genus is focused on the New World species and is not applicable to some exotic species.

DISTRIBUTION: This is principally an Old World genus; we examined species of Calogalesus from various parts of Africa, the Orient, and Australia. Two undescribed species are known to us from the Antilles (U.S. Virgin Is.) (CNCI), one of them probably a cosmopolitan species.

BIOLOGY: Unknown.

\section{Peckidium, new genus}

Figures 82, 83

Diagnosis ( $q$ ): Minute (about $1 \mathrm{~mm}$ ), gracile individuals; body color predominantly light brown; body predominantly smooth, highly shining, with only few scattered semierect hairs, no hairy cushions and no foamy structures; head considerably depressed, occiput very long, with deep longitudinal sulcus posteromedially; ocellar triangle situated far in front of anterior orbit of eye, leaving frons extremely short; face remarkably long; 
antenna 14-segmented, with nonabrupt 5segmented clava; mesosoma strongly depressed and flattened dorso-ventrally; pronotum strongly developed dorsally, subtrapezoidal, as long as mesoscutum; anterior scutellar pit replaced by arc of minute crenulae; propodeal keel replaced by deep depression; forewing very narrow, paddle-shaped, slightly subangular, with extremely long marginal cilia; submarginal vein reaching foremargin of wing without forming marginal vein; stigmal vein not developed; postmarginal vein extremely long, reaching almost to apex of wing; metasoma past petiole with very narrow trapezoidal T2 (abdominal T3) and T3 (abdominal T4) large, hence no syntergite; abdominal T8 with spiracles; abdominal T9 with cerci; laterotergites relatively narrow, loosely covering corresponding sternites; large sternite (past petiole) without longitudinal lateral groove.

DESCRIPTION ( $q$ ): HEAD. Head in dorsal view slightly longer than wide, subovoid, with antennal shelf and toruli moderately projecting; frons unarmed; ocellar triangle situated far in front of anterior orbit of eye; occiput with deep longitudinal sulcus posteromedially, occipital carina well developed, rimlike, with minute crenulae; occipital flange rudimentary, not steplike; head in lateral view considerably elongate, strongly depressed and flattened dorsally, antennal shelf moderately projecting; level of torulus at midpoint of eye; eye relatively small, subcircular, with relatively large ommatidia; oral carina not projecting; postgena relatively broad; head in frontal view with face almost flat, slightly longer than wide; clypeus remarkably narrow, distinctly higher than wide, with anterior margin truncate, anterolateral corners of clypeus acute; epistomal sulcus strongly developed at sides; labrum not exposed; malar sulcus deep, together with orbital sulcus (from inner orbit of eye to mandibular condyle) enclosing triangle in malar space; malar space shorter than eye height; cheek not striate; tentorial pit rudimentary; mandible short, strong, very broad at base, clasped, tridentate, middle tooth longest; palpi very short, palpal formula 3-1; head in ventral view with hypostomal bridge not developed; antenna 14-segmented; A1 relatively long, subcylindrical, apical rim without flaps, only moderately excavate ventrally; A3-A9 small, almost beadlike; clava nonabrupt, 5-segmented, clavomeres not flattened ventrally, A14 largest, without ventral pit. MESOSOMA. Mesosoma relatively short, distinctly depressed, much wider than high, flattened dorsally, in lateral view from pronotum to propodeum almost in one level; prothorax in dorsal view strongly developed, subtrapezoidal, medially as long as mesoscutum, with longitudinal sulcus medially; pronotal shoulders not developed; side of pronotum almost flat, epomium not developed, hairy cushion along anterior margin not developed; spiracle on prothorax relatively small, not projecting; mesoscutum strongly transverse, much wider than long, strongly flattened dorsally, with row of large crenulae along anterior margin (between notauli); parapsidal and anterior parallel lines not developed; notaulus weakly indicated in anterior half of mesoscutum, abbreviate in posterior half, noncrenulate, converging posteriorly; humeral and suprahumeral sulci not developed; transscutal articulation present but very fine; anterior scutellar pit replaced by arc of minute crenulae; scutellar disc broadly transverse, with no lateral keels, axillar, lateral and posterior scutellar pits not developed; posterior margin of axilla rounded; axillar depression elongate, narrow, relatively shallow; mesopleuron moderately convex, smooth and glabrous, with deep horizontal sulcus in median oblique depression; epicnemial pit well developed; sternaulus not developed; upper margin of mesopleuron (under tegula) rimlike; metanotum strongly reduced, replaced by deep crenulate groove, dorsellum not clearly defined; metapleuron smooth, glabrous, mirrorlike-shining, with ventral carina (between mid and hind coxae) and dorsal carina (below propodeum); propodeum relatively large, trapezoidal, with spiracle situated in extreme anterolateral corner; median keel replaced by shallow subtriangular depression, plica weakly developed, area between plica and median depression smooth, shining and glabrous; posterolateral corners of propodeum not projecting; nucha relatively long; forewing very narrow, paddle shaped, slightly subangular at midpoint, with extremely long marginal cilia; submarginal vein reaching foremargin of 
wing without forming marginal vein; stigmal vein not developed; postmarginal vein extremely long, reaching almost to apex of wing, with no other veins, posterior half of wing with whitish horizontal line parallelling posterior margin of wing; hind wing extremely narrow, stalked in anterior half, lanceolate, with long marginal cilia, submarginal vein tubular in basal half; legs relatively short and strong, trochanters distinctly elongate, femora distinctly clavate; apex of hind femur without flaps. METASOMA. Petiole moderately elongate, cylindrical, with irregular fine rugulosity, with moderate flange anteriorly; metasoma past petiole considerably depressed dorso-ventrally, much wider than high, with very narrow trapezoidal T2 (abdominal T3) and T3 (abdominal T4) large, hence no syntergite; abdominal T8 with spiracles; abdominal T9 with cerci; laterotergites relatively narrow; large sternite (past petiole) without longitudinal lateral groove.

Type SPECIES: Peckidium enigmaticum, new species ( $($ ) (described below), by present designation.

ReCOGNITION AND Relationships: Peckidium is no doubt the most unusual member of the family Diapriidae. Several character states (e.g., position of ocelli, long pronotum, venation of forewing, short trapezoidal T2) are truly unique not only for the Diapriinae but for the entire family Diapriidae. Therefore, the classification of Peckidium in the Diapriinae is considered as a tentative compromise.

ETYMOLOGY: The name of this unusual genus honors Dr. S. B. Peck (Carleton University, Ottawa), who collected the first individuals of $P$. enigmaticum, and over the years contributed generously with rich entomological material to the Canadian National Collection of Insects. The suffix idium is stressing the diminutive nature of this tiny wasp; the gender is neuter.

Distribution: The only known species, $P$. enigmaticum, may very well be tropicopolitan in distribution; the present known distribution indicates possible relict characters of the genus. We examined numerous specimens from tropical South and Central America (including the Antilles), the Guinea of West Africa, the Philippines (Leyte), and Papua New Guinea (New Britain).
Biology: The host is unknown. The majority of specimens examined were collected in undisturbed lowland tropical rainforests, i.e., not associated with human activity; however, one female (Carabobo, Venezuela) was collected in a coffee plantation.

\section{Peckidium enigmaticum, new species}

Figures 82, 83

DESCRIPTION: Holotype, $q$ : Length 1.1 $\mathrm{mm}$; body yellowish brown with legs (including coxae) slightly lighter; forewing generally infuscate, with distinct transverse lighter band near midpoint of wing (past frenal gutter). HEAD. Head in dorsal view slightly longer than wide (23:19); vertex and occiput smooth, shining, with few scattered setigerous punctures; median longitudinal sulcus on occiput reaching midway to posterior ocelli; temple slightly longer than eye (7:6), distinctly receding toward occipital carina; toruli separated by space subequal to their diameter; anterior ocellus remote from torulus by less than its own diameter; head in lateral view distinctly longer than high (23:12); eye height: malar space (9:5); head in frontal view with space between toruli only slightly emarginate, face smooth, shining, with scattered fine pilosity; antennal segments in relative proportions $(12: 3),(4: 2.5),(2: 2.5),(1.5$ : $2),(1: 2),(1: 2),(1: 2),(1.5: 2.5),(2: 3),(3: 4)$, (3.5:4.5), (4:4.5), (4.5:4.5), (6:4.5). MESOSOMA. Mesosoma longer than wide (35:22); pronotum medially (including cervix) only slightly shorter than mesoscutum (7:10), with median line finely crenulate; side of pronotum predominantly smooth; mesoscutum strongly transverse, smooth and shining, almost glabrous, distinctly wider than long (18: $10)$; notaulus widest anteriorly, gradually tapering posteriorly, not exceeding midpoint of mesoscutum; axilla relatively large, subtriangular, scutellar disc smooth, shining, almost glabrous; plica complete, represented by irregular rugulose carina; forewing with longest marginal cilia subequal to wing width. METASOMA. Petiole moderately elongate (14:5.5); T2 (abdominal T3) narrow, trapezoidal, transverse, wider than long (15:2.5); T3 (abdominal T4) very large, as long as wide (25:25), with scattered semiappressed hairs, predominantly at sides and along pos- 
terior margin; T5 and following tergites with long semierect hairs; cercus very small, with two long bristles.

MALE: Recently the junior author collected three males that obviously belonged to Peckidium. However, at this time we prefer not to assign these males to $P$. enigmaticum. Surprisingly, the antenna is 12-segmented in two males and 13-segmented in another male.

TyPe MATERIAL: 26․ Holotype, + (CNC no. 22460), DOMINICAN REPUBLIC, Prov. Barahona, $7 \mathrm{~km}$ NW Paraiso, $200 \mathrm{~m}$, November 27-December 4, 1991, L. Masner \& S.B. Peck, FIT, rainforest remnant well preserved. Paratypes, 19 , COSTA RICA, Heredia Prov., Braulio Carillo N.P., 1400 m, June 12, 1985, H. Goulet \& L. Masner, s.s.; $1 \%$, Guanacaste Prov. Guanacaste National Park, Biological Station Pitilla, 1200 m, February 11, 1995, L. Masner, YPT; 1 9 , CUBA, Pinar Del Rio, Sierra Del Rosario, Rangel, $15 \mathrm{~km}$ S Cinco Pesos, June 30, 1990, M.A. Ivie, Berlese from dead log and leaf litter; 1 ㅇ, Santiago Prov., $6 \mathrm{~km}$ NE Siboney, 150 $\mathrm{m}$, Tres Arroyos, Rio Jurangua, $19^{\circ} 59^{\prime} \mathrm{N}$, $75^{\circ} 60^{\prime} \mathrm{W}$, December 16, 1995, L. Masner, YPT in creek bed; 19 , DOMINICAN REPUBLIC, same data as holotype; $2 q$, ECUADOR, Pichincha Prov., $47 \mathrm{~km}$ S Santo Domingo, Rio Palenque Station, June-August 1985, S. \& J. Peck, lowland rainforest, FIT; 1 ㅇ, same as above, July 22-31, 1976; 1 , , same as above, February 4, 1983, L. Masner, s.s.; 1 , Napo, 400 m, Jatun Sacha Lodge, $21 \mathrm{~km}$ E Puerto Napo, July 20, 1994, Levy \& Génier, in FIT rainforest; 1 , FRENCH GUIANA, $5 \mathrm{~km} \mathrm{~N}$ Saul, $3^{\circ} 38^{\prime} \mathrm{N}$, $53^{\circ} 13^{\prime} \mathrm{W}, 160-260 \mathrm{~m}$, October 1995, D. Grimaldi, YPT in creek bed; 49 , GUATEMALA, Dep. Izabal, Las Escobas, 8 km SW Puerto Barrilos, 150-200 m, November 1214, 1986, M. Sharkey, from sifted bog and bracket fungi on log; 19 , PANAMA, Canal Zone, Barro Colorado Is., July 29, 1976, R.B. \& L.S. Kimsey; 1 \%, same as above, February 27, 1976, A. Newton, Berlese leaflitter forest floor; 19 , PERU, Tambopata Prov., Dep. Madre de Dios, 16 km NE Puerto Maldonado, Res. Cuzco, Amazonica, $12^{\circ} 33^{\prime} \mathrm{S}, 69^{\circ} 03^{\prime} \mathrm{W}, 200 \mathrm{~m}$, June 17, 1989, J.S. Ashe \& R.A. Leschen, FIT no. 35; 3 ㅇ, VENEZUELA, Guri, December 28, 1987, M. Sanborne, MT FIT; 19 , Carabobo, Pal- michal, Canoabo, J.L. Garcia (MIZA); 1 , El Pao Pilancones, January 12-16, 1995, A. Alemán, MT (MIZA); 19, TOBAGO, 10 $\mathrm{km}$ NE Roxborough, $450 \mathrm{~m}$, Gilpin trail, May 28-31, 1993, S.B. Peck, MT in rainforest; 1 ㅇ, TRINIDAD, $8 \mathrm{~km}$ N Arima, Simla Res. Sta., 260 m, June 24-July 8, 1993, S.B. Peck, FIT, in lower montane forest; 1 i AFRICA, Guinea, Mt. Nimba, $7^{\circ} 42^{\prime} \mathrm{N}, 8^{\circ} 23^{\prime} \mathrm{W}$, December 1990-March 1991, L. Leblanc, FIT rainforest; $1 \%$, same as above, Gouan River, July 27-30, 1990; 1 우, PHILIPPINES, Leyte near Baybay, Mt. Pangasugan, $10^{\circ} 45^{\prime} \mathrm{N}, 124^{\circ} 50^{\prime} \mathrm{E}, 250 \mathrm{~m}$, May $28-30$, 1987, D.C. Darling, YPT; 19 , PAPUA NEW GUINEA, East New Britain, Baynings Mts., base camp DPI station, river, April 3-15, 1999, L. Leblanc \& M. Kalaman, FIT/ YPT.

ETYMOLOGY: From enigmaticum (Latin), referring to the mysterious nature of this species.

DistRIBUTION: Neotropical region (Antilles, Central and South America), Ethiopian region (West Africa), Oriental region (Philippines), and Australian region (Papua New Guinea). The real distribution is probably much wider as the tiny individuals are easily overlooked in bulk material.

BIOLOGY: Host unknown; several individuals were sifted from forest leaf litter (with fungi) in lowland rainforests.

VARIATION: Despite its tropicopolitan distribution spanning four zoogeographic regions, individuals of $P$. enigmaticum exhibit a surprisingly low degree of variation. Among the 26 specimens examined, the body size varies from 1 to $1.1 \mathrm{~mm}$. Some specimens are slightly darker (castaneous brown) than the holotype. The median longitudinal sulcus on occiput may be longer or shorter and the median longitudinal sulcus on pronotum may be less developed in some individuals. The length of notaulus is also subject to minor variation.

\section{ABBREVIATIONS}

$$
\begin{array}{ll}
\text { a } 9 & \text { female antenna } \\
\text { a } \hat{} & \text { male antenna } \\
\text { A1 (scape), } & \text { antennomeres } \\
\text { A2 (pedi- } & \\
\text { cel), A3... } &
\end{array}
$$




\begin{tabular}{|c|c|c|c|}
\hline $\mathrm{acl}$ & antennal clava & pnt & pronotum (side) \\
\hline $\mathrm{ad}$ & axillar depression & ppl & parapsidal line \\
\hline ap & axillar pit & psp & posterior scutellar pits \\
\hline apl & anterior parallel line & Rs2 & second abscissa of $R$ vein \\
\hline as & antennal shelf & Rs3 & third abscissa of $\mathrm{R}$ vein \\
\hline asp & anterior scutellar pit(s) & $\mathrm{S} 1, \mathrm{~S} 2, \mathrm{~S} 3$ & sternites \\
\hline $\mathrm{ax}$ & axilla & $\mathrm{SC}$ & scutellum \\
\hline bv & basal vein & sd & scutellar disc \\
\hline ce & cervix & sp1 & pronotal spiracle \\
\hline $\mathrm{cl}$ & clypeus & sp2 & propodeal spiracle \\
\hline cx1 & forecoxa & stn & sternaulus \\
\hline $\mathrm{cx} 2$ & mid coxa & stv & stigmal vein \\
\hline $\begin{array}{l}\text { cx3 } \\
\text { ds }\end{array}$ & $\begin{array}{l}\text { nind coxa } \\
\text { dorsellum }\end{array}$ & sv & submarginal vein \\
\hline ed & epistomal declivity & $\mathrm{T} 1, \mathrm{~T} 2, \mathrm{~T} 3$ & tergites \\
\hline eh & eye height & & temple \\
\hline em & epomium & $\operatorname{tg}$ & tegula \\
\hline ep & epicnemial pit & tp & tentorial pit \\
\hline $\mathrm{fc}$ & face & $\operatorname{tr}$ & torulus \\
\hline $\mathrm{fr}$ & frons & tsa & transscutal articulation \\
\hline hd & head in dorsal view & ueo & upper eye orbit \\
\hline hf & head in frontal view & $\mathrm{w}$ & forewing \\
\hline $\mathrm{HH}$ & head height & \multirow{3}{*}{\multicolumn{2}{|c|}{ ACKNOWLEDGMENTS }} \\
\hline hl & head in lateral view & & \\
\hline $\begin{array}{l}\mathrm{HL} \\
\mathrm{hs}\end{array}$ & $\begin{array}{l}\text { head length } \\
\text { humeral sulcus }\end{array}$ & & \\
\hline HW & head width & \multirow{28}{*}{\multicolumn{2}{|c|}{$\begin{array}{l}\text { Our sincere thanks are extended to cura- } \\
\text { tors and staff of institutions (listed under Ma- } \\
\text { terials) for the loan of types and other rele- } \\
\text { vant material. Similarly, we are grateful to } \\
\text { numerous friends and colleagues who, over } \\
\text { the years, supplied or donated valuable ma- } \\
\text { terial to the Canadian National Collection in } \\
\text { Ottawa. The senior author wishes to ac- } \\
\text { knowledge support by the Instituto Nacional } \\
\text { de Biodiversidad (INBio, Costa Rica) for two } \\
\text { major collecting trips in Costa Rica. The ju- } \\
\text { nior author is grateful to Centro de Investi- } \\
\text { gaciones de la Universidad Simon Rodriguez } \\
\text { for supporting his sabbatical visit and train- } \\
\text { ing in Canada (1993). We thank S. Rigby } \\
\text { (presently at the Agriculture Research Sta- } \\
\text { tion in Kentville, NS) for preparing all but } \\
\text { two of the line drawings. Our very special } \\
\text { thanks go to Ms. J. Denis-Gill for the mas- } \\
\text { sive support in editing the text, preparing the } \\
\text { plates and captions, and proofreading the } \\
\text { manuscript. Mr. David Notton (Reading Mu- } \\
\text { seum, England), Mr. Marco Gaiani (Univer- } \\
\text { sidad Central de Venezuela, Maracay), Dr. } \\
\text { Robert Wharton and Mr. Matthew Yoder } \\
\text { (Texas A\&M, USA), and Dr. Paul Marsh } \\
\text { (University of Kansas, USA) reviewed the } \\
\text { manuscript and made valuable comments. }\end{array}$}} \\
\hline leo & lower eye orbit & & \\
\hline & medial vein & & \\
\hline $\mathrm{M}+\mathrm{Cu} 1$ & medial and cubital veins & & \\
\hline & marginal cilia & & \\
\hline md & mandible & & \\
\hline MH & mesosoma height & & \\
\hline $\begin{array}{l}\text { ML } \\
\text { mpk }\end{array}$ & mesosoma length & & \\
\hline mpl & mesopleuron & & \\
\hline $\mathrm{ms}$ & malar sulcus & & \\
\hline $\mathrm{msc}$ & mesoscutum & & \\
\hline $\mathrm{msl}$ & mesosoma in lateral view & & \\
\hline mtd & metasoma in dorsal view & & \\
\hline MTH & metasoma height & & \\
\hline $\mathrm{mtn}$ & metanotum & & \\
\hline & $\begin{array}{l}\text { metapleuron } \\
\text { marginal vein }\end{array}$ & & \\
\hline MTW & metasoma width & & \\
\hline MW & mesosoma width & & \\
\hline & notaulus & & \\
\hline $\mathrm{nu}$ & nucha & & \\
\hline oeo & outer eye orbit & & \\
\hline of & occipital flange & & \\
\hline pc & pronotal cushion & & \\
\hline peo & posterior eye orbit & & \\
\hline & $\begin{array}{l}\text { petiole } \\
\text { postgena }\end{array}$ & & \\
\hline pgc & postgenal cushion & & \\
\hline & $+\mathrm{ica}$ & & \\
\hline pmv & postmarginal vein & & \\
\hline
\end{tabular}




\section{REFERENCES}

Ashmead, W. H. 1893. Monograph of the North American Proctotrypidae. United States National Museum Bulletin 45: 1-472.

Ashmead, W. H. 1895. Report on the parasitic Hymenoptera of the island of Grenada, comprising the families Cynipidae, Ichneumonidae, Braconidae, and Proctotrypidae. Proceedings of the Zoological Society of London 1895: 742-821.

Ashmead, W. H. 1903. Classification of the pointed-tailed wasps, or the superfamily Proctotrypoidea-II. Journal of the New York Entomological Society 11: 31 .

Backlund, H. 1945. Wreck fauna of Sweden and Finland, ecology and chorology. Opuscula entomologica supplementum 5: 1-237.

Baudoin, R. 1949. Un Hyménoptère nouveau pour la zone intercotidale de Roscoff. In XIIIe Congrès International de Zoologie, Paris: 469-470.

Baudoin, R. 1952. Contribution à l'œcologie et à la biogéographie de la zone intercotidale des Charentes. C.R. sommaires Biogéographie 251: 73-82.

Borgmeier, T. 1939. Sobre alguns Diapriideos myrmecophilos, principalmente do Brasil (Hym. Diapriidae). Revista de Entomología 10: 530-545.

Brèthes, J. 1911. Himenopteros Argentinos. Anales del Museo Nacional de Historia Natural de Buenos Aires 20: 205-316.

Brèthes, J. 1927a. Parásitos e hipersáto de "Diatraea saccharalis" en la caña de azúcar, en Tucumán. Revista industrial y agrícola de Tucumán 17: 163-166.

Brèthes, J. 1927b. Hyménoptères Sud-Américains du Deutsches Entomologisches Institut: Terebrantia. Entomologische Mitteilungen 16: 296309, 319-335.

Brown, H. P. 1967. Psephenids (Coleoptera: Dryopoidea) parasitized by eulophid and diapriid wasps (Hymenoptera: Chalcidoidea and Proctotrupoidea). American Zoologist 7(2): 31.

Brues, C. T. 1903. Descriptions of new ant-like and myrmecophilous Hymenoptera. Transactions of the American Entomological Society 29: 119-128.

Brues, C. T. 1915. Some new parasitic Hymenoptera from Brasil. Psyche 22: 1-13.

Crawford, J. C. 1910. New Hymenoptera from the Philippine Islands. Proceedings of the United States National Museum 38: 119-133.

Dalla Torre, K. W. v. 1898a. Catalogus hymenopterorum hucusque ... IV: Braconidae. 1323.

Dalla Torre, K. W. v. 1898b. Catalogus hymenopterorum hucusque ... V: Chalcididae et Proctotrupidae. 1-598.
De Santis, L. 1967. Catálogo de los himenópteros argentinos de la Serie Parasitica incluyendo Bethyloidea. Provincia de Buenos Aires Gobernacion, Comision de Investigacion Cientifica. [Direccion de impresiones del estado y boletin oficial]. 337 pp.

De Santis, L. 1980. Catálogo de los himenópteros brasileños de la Serie Parasitica incluyendo Bethyloidea. [Editora Universidade Federal do Parana Curitiba]. 395 pp.

Dodd, A. P. 1920. Notes on the exotic Proctotrupoidea in the British and Oxford University Museums, with descriptions of new genera and species. Transactions of the Entomological Society of London 1919: 321-382.

Evans, H. E. 1969. Phoretic copulation in Hymenoptera. Entomological News 80: 113-124.

Fabritius, K. 1968. Antipapria n. gen., eine neue Diapriiden-Gattung aus Argentinien (Hymenoptera, Proctotrupoidea). Travaux du Muséum d'histoire naturelle "Grigore Antipa" 8: 841844.

Fabritius, K. 1974. Die Gattung Doliopria Kieffer 1910 und nebenstehende Gattungen (Hymenoptera: Diapriidae). Folia Entomologica Hungarica 27: 53-57.

Ferrière, C. 1929. Nouveaux Diapriides du Brésil, hôtes des Eciton. Zoologischer Anzeiger 82: 156-171.

Fischer, C. R. 1940. Adelioneiva concolor, nov. gen. n. sp., um novo diapriideo myrmecophilo de Goyaz (Hym. Diapriidae). Revista de Entomologia 11: 397-401.

Foerster, A. 1856. Hymenopterologische Studien. II. Heft. Chalcidiae und Proctotrupii, 2: 1-152. Aachen: Ernsteer Meer.

Fouts, R. M. 1924. New bethylid and serphoid parasites from North America (Hymenoptera). Proceedings of the Entomological Society of Washington 26: 159-166.

Fouts, R. M. 1939. Descriptions of one new genus and three new species of Diapriidae (Hymenoptera). Proceedings of the Entomological Society of Washington 41: 260-263.

García, J. L. 2000. Nuevos registros genéricos para Venezuela de Hymenoptera Parasítica. Boletín de Entomología Venezolana 15(1): 113-117.

Goulet, H., and J. T. Huber. 1993. Hymenoptera of the world: An identification guide to families. Agriculture Canada Publication 1894/E: 537-557.

Haliday, A. H. 1829. In Curtis, A guide to an arrangement of British insects, column 108. London.

Haliday, A. H. 1857. Note on a peculiar form of the ovaries observed in a hymenopterous insect, constituting a new genus and species of 
the family Diapridae. Natural History Review 4: 166-174.

Hanson, P., and I. D. Gauld. 1995. The Hymenoptera of Costa Rica. London: Oxford University Press.

Hellén, W. 1963. Die Diapriinen Finnlands (Hymenoptera; Proctotrupoidea). Fauna Fennica 14: $1-35$.

Hogue, C. L. 1973. A taxonomic review of the genus Maruina (Diptera: Psychodidae). Science Bulletin of the Natural History Museum, Los Angeles County 17: 1-69.

Holmgren, N. 1908. Über einige myrmecophile Insekten aus Bolivia und Peru. Zoologischer Anzeiger 33: 337-349.

Huggert, L., and L. Masner. 1983. A review of myrmecophilic-symphilic diapriid wasps in the Holarctic realm, with descriptions of new taxa and a key to genera (Hymenoptera Proctotrupoidea: Diapriidae). Contributions to the American Entomological Institute 20: 63-89.

Johnson, N. F. 1992. Catalog of world species of Proctotrupoidea, exclusive of Platygastridae (Hymenoptera). Memoirs of the American Entomological Institute 51: 1-825.

Kieffer, J. J. 1905a. Nouveaux Proctotrypides exotiques conservés au Musée Civique de Gênes. Annali del Museo Civico di Storia Naturale di Genova 2(2): 9-39.

Kieffer, J. J. 1905b. Description de nouveaux Hyménoptères exotiques. Bulletin de la Société d'Histoire Naturelle de Metz 24: 85-114.

Kieffer, J. J. 1906. Description de quelques nouveaux serphides. Bulletin de la Societe d'Histoire Naturelle de Metz 25: 1-7.

Kieffer, J. J. 1907. Beschreibung neuer im British Museum zu London aufbewahrter Proctotrypiden. Berliner Entomologische Zietschrift 51: 279-302.

Kieffer, J. J. 1910a. In E. André, Species des Hyménoptères d'Europe et d'Algérie 10: 593-752. Paris.

Kieffer, J. J. 1910b. Beschreibung neuer südamerikanischer im Zoologischen Museum zu Berlin aufbewahrter Diapriiden. Entomologische Rundschau 27: 39-40, 46-48, 52-56.

Kieffer, J. J. 1911. In E. André, Species des Hyménoptères d'Europe et d'Algérie 10: 753-912. Paris.

Kieffer, J. J. 1912. Hymenoptera fam. Diapriidae. In P. Wytsman, Genera Insectorum, fascicle 124: 1-75.

Kieffer, J. J. 1913. Serphides des Îles Philippines. Insecta 3: 253-260.

Kieffer, J. J. 1916. Diapriidae. Das Tierreich 44. $1-627$.
Kieffer, J. J. 1921. Proctotrypides hôtes des fourmis en Argentine. Anales de la Sociedad Científica Argentina 91: 36-41.

Kieffer, J. J. 1922. Trois nouveaux Hymenoptères d'Argentine recuellis par C. Bruch. Anales de la Sociedad Cientifica Argentina 94: 205-208.

Kistner, D. H., and L. N. Davis. 1989. New species of Notoxopria and their behavior, with notes on Mimopria (Hymenoptera: Diapriidae). Sociobiology 16: 217-238.

Kozlov, M. A. 1978. In G. S. Medvedev, Keys to Insects of the European Part of USSR;Hymenoptera, superfamily Proctotrupoidea. 3(2): 538-691. Leningrad: Nauka.

Krombein K. V., and B. D. Burks. 1967. Hymenoptera of America north of Mexico. Synoptic Catalog. United States Department of Agriculture Monograph 2(2nd suppl.): 1-584. Washington.

Latreille, P. A. 1796. Précis des charactères génériques des insectes, disposés dans un order naturel. Paris: Prévôt. 110 pp.

Loiácono, M. S. 1981. Notas sobre Diapriinae neotropicales (Hymenoptera, Diapriidae). Revista de la Sociedad Entomológica Argentina 40(1-4): 237-241.

Loiácono, M. S. 1987. Un nuevo diáprido (Hymenoptera) parasitoide de larvas de Acromyrmex ambiguus (Emery) (Hymemoptera, Formicidae) en el Uruguay. Revista de la Sociedad Entomológica Argentina 44(2): 129-136.

Loiácono, M. S., and C. B. Margaría. 2000. Systematic and cladistic analysis of the myrmecophilic genus Gymnopria Loiácono (Hymenoptera: Diapriidae). Insect Systematics \& Evolution 31(2): 187-200.

Maneval, H. 1939. Deux nouveaux genres et un nouvelle espèce de Diapriidae (Hym.) Bulletin de la Société Entomologique de France 44: 168-172.

Mann, W. M. 1918. Myrmecophilous insects from Cuba. Psyche 25: 104-106.

Mann, W. M. 1923. Two serphoid guests of Eciton (Hym.). Proceedings of the Entomological Society of Washington 25: 181-182.

Masner, L. 1959. A revision of ecitophilous Diapriid-genus Mimopria Holmgren (Hym. Proctotrupoidea). Insectes Sociaux 6(4): 361-367.

Masner, L. 1964a. A comparison of some Nearctic and Palearctic genera of Proctotrupoidea ( $\mathrm{Hy}-$ menoptera) with revisional notes. Casopis Československé Společnosti Entomologické 61: 123-155.

Masner, L. 1964b. A redescription of three species of Proctotrupoidea (Hymenoptera) from Jurine's collection. Entomophaga 9(1): 81-89.

Masner, L. 1965. The types of Proctotrupoidea (Hymenoptera) in the British Museum (Nat. 
Hist.) and the Hope Department of Entomology (Oxford). Bulletin of the British Museum (Natural History) Entomology, Suppl. 1: 1-154.

Masner, L. 1969a. The Provancher species of Proctotrupoidea (Hymenoptera). Naturaliste Canadien 96: 775-784.

Masner, L. 1969b. Two new genera of Diapriinae (Diapriidae, Hymenoptera) with transantarctic relationships. Psyche 76: 311-325.

Masner, L. 1974. Szelenyisca n. gen., a new genus of Neotropical Diapriidae (Hymenoptera: Proctotrupoidea) Folia Entomologica Hungarica 27: 109-111.

Masner, L. 1976. Notes on the ecitophilous diapriid genus Mimopria Holmgren (Hymenoptera: Proctotrupoidea, Diapriidae). Canadian Entomologist 108: 123-126.

Masner, L. 1977. A new genus of ecitophilous diapriid wasps from Arizona (Hymenoptera: Proctotrupoidea: Diapriidae). Canadian Entomologist 109: 33-36.

Masner, L. 1991. Revision of Spilomicrus Westwood in America north of Mexico (Hymenoptera: Proctotrupoidea, Diapriidae). Canadian Entomologist 123: 107-177.

Masner, L., and G.A.P. Gibson. 1979. The separation bag - a new device to aid in collecting insects. Canadian Entomologist 111: 11971198.

Masner, L., and H. Goulet. 1981. A new model of flight-interception trap for some hymenopterous insects. Entomological News 92(5): 199-202.

Masner, L., and L. Huggert. 1989. World review and keys to genera of the subfamily Inostemmatinae with reassignment of the taxa to the Platygastrinae and Sceliotrachelinae (Hymenoptera: Platygasteridae). Memoirs of the Entomological Society of Canada 147: 1-214.

Masner, L., and C.F.W. Muesebeck. 1968. The types of Proctotrupoidea (Hymenoptera) in the United States National Museum. United States National Museum Bulletin 270: 1-143.

Masner, L, and A. Sundholm. 1959. Some nomenclatoric problems in Diapriidae (Hym., Proctotrupoidea) Časopis České Společnosti Entomologické 56: 161-168.

Muesebeck, C. F. W. 1980. The Nearctic parasitic wasps of the genera Psilus Panzer and Coptera Say (Hymenoptera. Proctotrupoidea, Diapriinae). United States Department of Agriculture Technical Bulletin No. 1617: 1-71.

Muesebeck, C. F. W., and L. M. Walkley. 1951. In C.F.W. Muesebeck, K.V. Krombein, and H.K. Townes, Hymenoptera of America north of Mexico. Synoptic Catalogue. United States Department of Agriculture Monograph 2: 11420.
Muesebeck, C. F. W., and L. M. Walkley. 1956. Type species of the genera and subgenera of parasitic wasps comprising the superfamily Proctotrupoidea (Order Hymenoptera). Proceedings of the United States National Museum 105: 319-419.

Nixon, G. E. J. 1980. Diapriidae (Diapriinae). Hymenoptera, Proctotrupoidea. Handbooks for the Identification of British Insects 8(3): 1-55.

Notton, D. G. 1991. Some Diptera host records for the species of Basalys and Trichopria (Hym., Diapriidae). Entomologist's Monthly Magazine 127: 123-126.

Notton, D. G. 1993. New species of Trichopria and Diapria from the British Isles (Hym., Proctotrupoidea, Diapriidae). Entomologist's Monthly Magazine 129: 139-150.

Notton, D. G. 1995. A catalogue of type material of the British Diapria genus group (Hymenoptera, Proctotrupoidea, Diapriidae). Beiträge zur Entomologie 45: 269-298.

Ogloblin, A. A. 1955. Un genero nuevo de Diapriinae de Patagonia (Hymenoptera, Diapriidae). Neotropica 1(6): 85-88.

Ogloblin, A. A. 1957. Los Insectos de las Islas Juan Fernández. 35. Mymaridae, Ceraphronidae, Diapriidae y Scelionidae (Hymenoptera). Revista Chilena Entomología 5: 413-444.

Ogloblin, A. A. 1958. Un género nuevo de la familia Diapriidae (Hymenoptera). Neotropica 4: 13-16.

Ogloblin, A. A. 1959. Un género nuevo de la familia Diapriidae (Hym.) de Patagonia. Revista de la Sociedad Entomológica Argentina 21: 4346.

Ogloblin, A. A. 1960. Tres especies nuevas del genero Doliopria del Ecuador (Diapriidae, Hymenoptera). Revista de la Sociedad Entomológica Argentina 22: 1-4, 71-76.

Panzer, G. W. F. 1801. Faunae insectorum Germaniae initia oder Deutschlands Insecten 83: 111.

Peck, S. B., and J. Cook. 1992. Use of "car nets" to sample flying Micro-Coleoptera. Canadian Entomologist 124: 745-749.

Pschorn-Walcher, H. 1957. Zur Kenntnis der Diapriidae (Hym., Proctotrupoidea). Mitteilungen der Schweizerischen Entomologischen Gesellschaft 29: 58-88.

Risbec, J. 1950. Contribution à l'étude des Proctotrupidae (Serphiidae). Proctotrupidés de la Section technique d'Agriculture tropicale (A.O.F.) et Proctotrupidés du Muséum national d'Histoire naturelle (Afrique et Colonies français). Travaux du Laboratoire d'Entomologie du secteur Soudanais de Researches Agronomiques, Gouvernement Générale de l'Afrique Occidentale Français. 639 pp. 
Sanders, G. E. 1911. Notes on the breeding of Tropidopria conica Fabr. Canadian Entomologist 43: 48-50.

Say, T. 1836. Descriptions of new species of North American Hymenoptera, and observations on some already described. Boston Journal of Natural History 1: 209-305, 361-416.

Silvestri, F. 1914. Report of an expedition to Africa in seach of the natural enemies of fruit flies (Trypaneidae), with descriptions, observations and biological notes. Bulletin of Entomology and Agriculture of Hawaii 3: 1-176.

Simmonds, F. J. 1953. Parasites of the frit-fly, Oscinella frit (L.) in eastern North America. Bulletin of Entomological Research 43: 503-542.

Sundholm, A. 1960. On Diapria Latreille and allied genera (Hym., Diapriidae). Opuscula Entomologica 25: 215-223.

Szabo, J. B. 1961. Neue paläarktische Gattungen und Arten der Diapriiden in der Sammlung des Ungarischen Naturwissenschaftlichen Museums (Hymenoptera, Proctotrupoidea, Diapri- idae). Annales Historico-Naturales Musei Nationalis Hungarici 53: 491-494.

Townes, H. K. 1972. A light-weight Malaise trap. Entomological News 83: 239-247.

Wasmann, E. 1925. Die Ameisenmimikry. Abhandlungen zur theoretischen Biologie 19: 1164.

Westwood, J. O. 1832. Descriptions of several new British forms amongst the parasitic hymenopterous insects. London \& Edinburgh Philosophical Magazine and Journal of Science 1: 127-129.

Westwood, J. O. 1833. Descriptions of several new British forms amongst the parasitic hymenopterous insect. London \& Edinburgh Philosophical Magazine and Journal of Science 3: 342-344.

Wing, M. W. 1951. A new genus and species of myrmecophilous Diapriidae with taxonomic and biological notes on related forms. Transactions of the Royal Entomological Society of London 102: 195-210. 


\section{INDEX}

(synonyms in italics)

Acanthopria, 61

Acidopria, 70

Adelioneiva, 61

Adeliopria, 44

Aneurhynchus, 8

Aneuropria, 31

Antipapria, 54

Aparamesius, 52

Apopria, 63

Apopria coveri, 65

Ashmeadopria, 108

Asolenopsia, 65

Asolenopsia gibba, 67

Atrichopria, 89

Aulatopria, 39

Austropria, 116

Auxopaedeutes, 67

Avoca, 69

Avoca collaris, 70

\section{Bakeria, 54}

Basalys, 70

Bruchopria, 39

Bruchopria pentatoma, 40

Bruesopria, 72

Caecopria, 113

Calogalesus, 116

Ceratopria, 108

Chilomicrus, 40

Chilomicrus pecki, 42

Coptera, 33

Corynopria, 93

Cracinopria, 67

Diapria, 75

Diapriini, 60

Doddius, 43

Doddius rugosus, 44

Doliopria, 76

Doliopria reichenspergeri, 106

\section{Ecitovagus, 77}

Ecitovagus gibbus, 78
Eladio, 79

Eladio cruzi, 80

Entomacis, 44

Epomium, 46

Epomium cicatrix, 48

Eriopria, 48

Euplacopria, 65

Ferrugenus, 48

Galesus, 37

Gymnopria, 105

Hansona, 81

Hansona pauli, 82

Hemilexis, 44

Hemilexodes, 44

Hoplopria, 57

Idiotypa, 51

Kiefferopria, 89

Labidopria, 83

Labolips, 8

Lepidopria, 11

Leucopria, 85

Leucopria cylindricornis, 86

Linkiola, 57

Loxotropa auct., 57

Martinica, 76

Megaplastopria, 87

Mimopria, 89

Mimopriella, 90

Mitropria, 92

Monelata, 93

Myrmecopria, 94

Myrmecopria mellea, 96

Neivapria, 96

Nesopria, 70

Notoxoides, 97

Notoxopria, 97

Omopria, 99

Omopria brevipalpis, 100
Ortona, 34

Ortona hansoni, 36

Paramesius, 52

Peckidium, 117

Peckidium enigmaticum, 119

Pentapria, 54

Pezopria, 31

Phaenopria, 108

Philolestoides, 101

Philolestoides wasmanni, 109

Planopria, 108

Planopriella, 102

Platymischus, 102

Platymischus dilatatus, 103

Plutopria, 57

Poecilopsilus, 56

Psilini, 31

Psilogasteroides, 97

Psilus, 37

Psychopria, 103

Psychopria hoguei, 104

Schizogalesus, 33

Solenopsia, 11

Spilomicrini, 38

Spilomicrinus, 54

Spilomicrus, 57

Szelenyiopria, 105

Szelenyiopria lucens, 106

Szelenyisca, 106

Townesella, 107

Townesella marjoriae, 108

Trichopria, 108

Tritopria, 57

Tropidopria, 75

Turripria, 110

Turripria woldai, 111

Xanthopria, 112

Xanthopria nitida, 113

Xanthopria opaca, 113

Xenismarus, 59

Xenopria, 54

Xyalopria, 87 


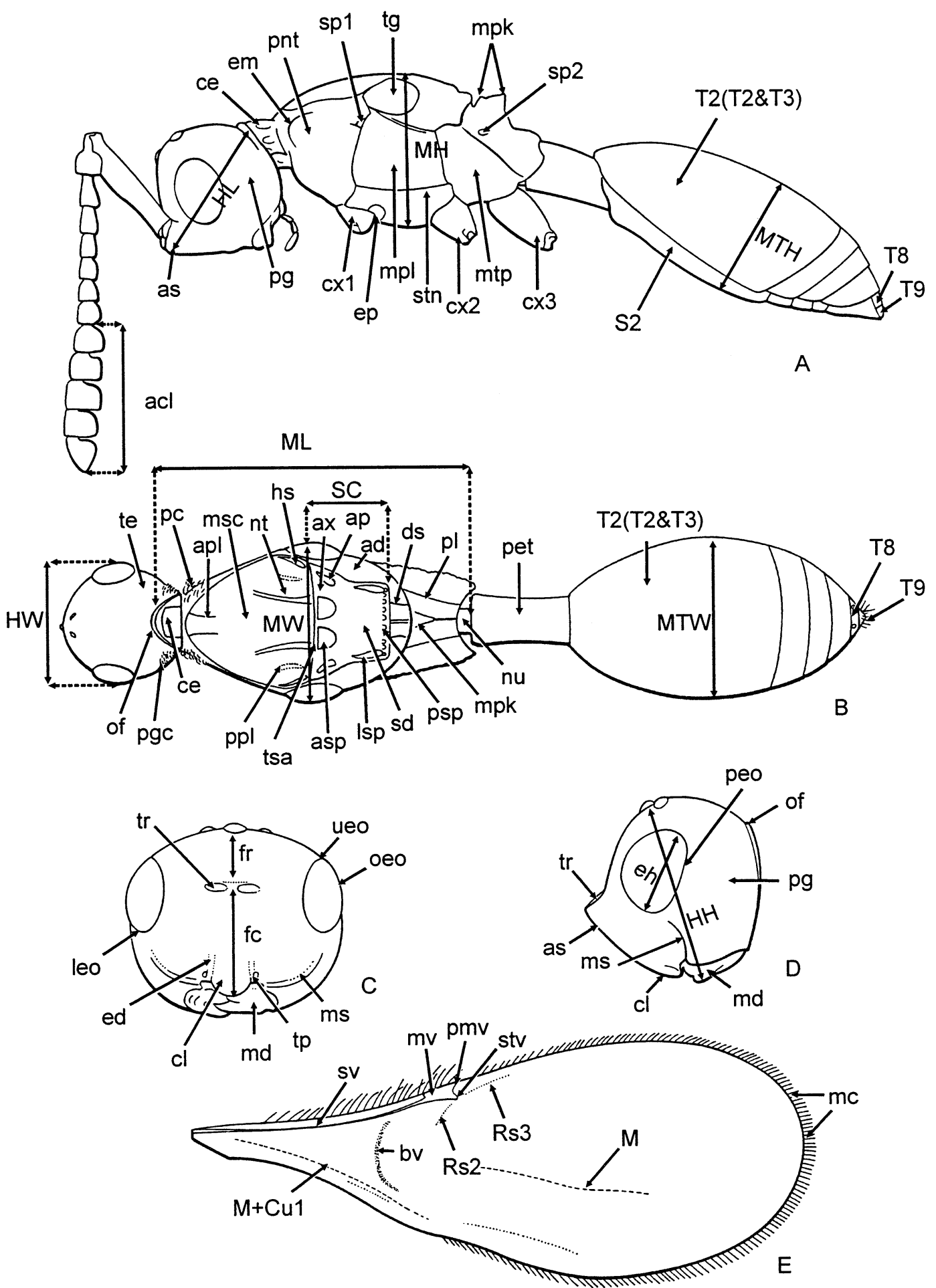

Figs. A-E. A. Diapriinae, lateral view; B. Diapriinae, dorsal view; C. Diapriinae head, frontal view; D. Diapriinae head, lateral view; E. Diapriinae, forewing. 

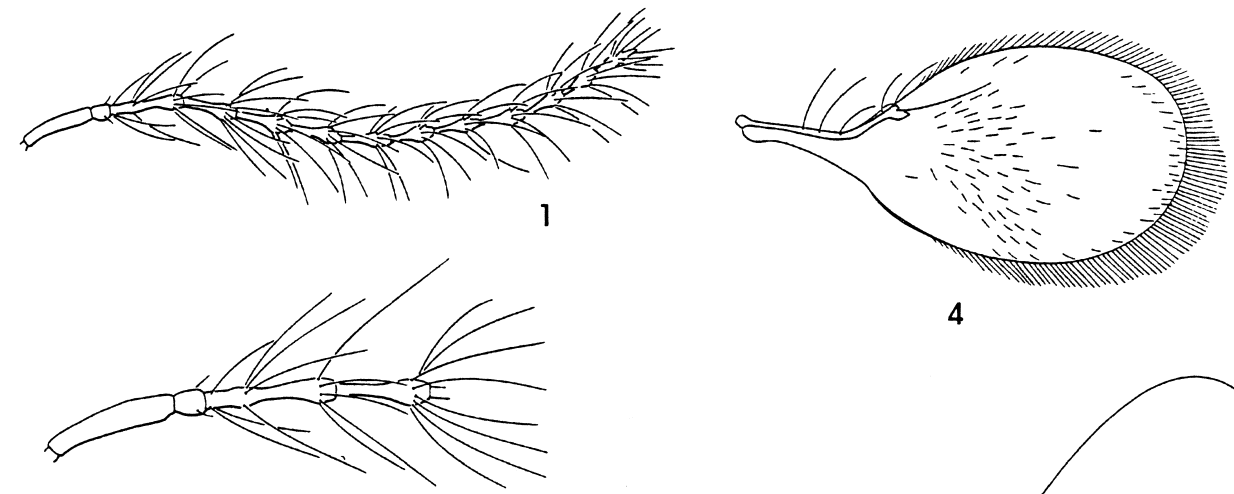

2

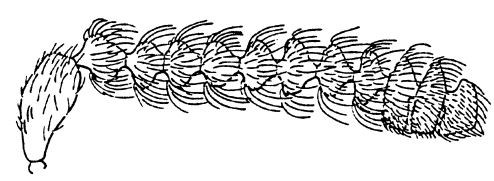

3
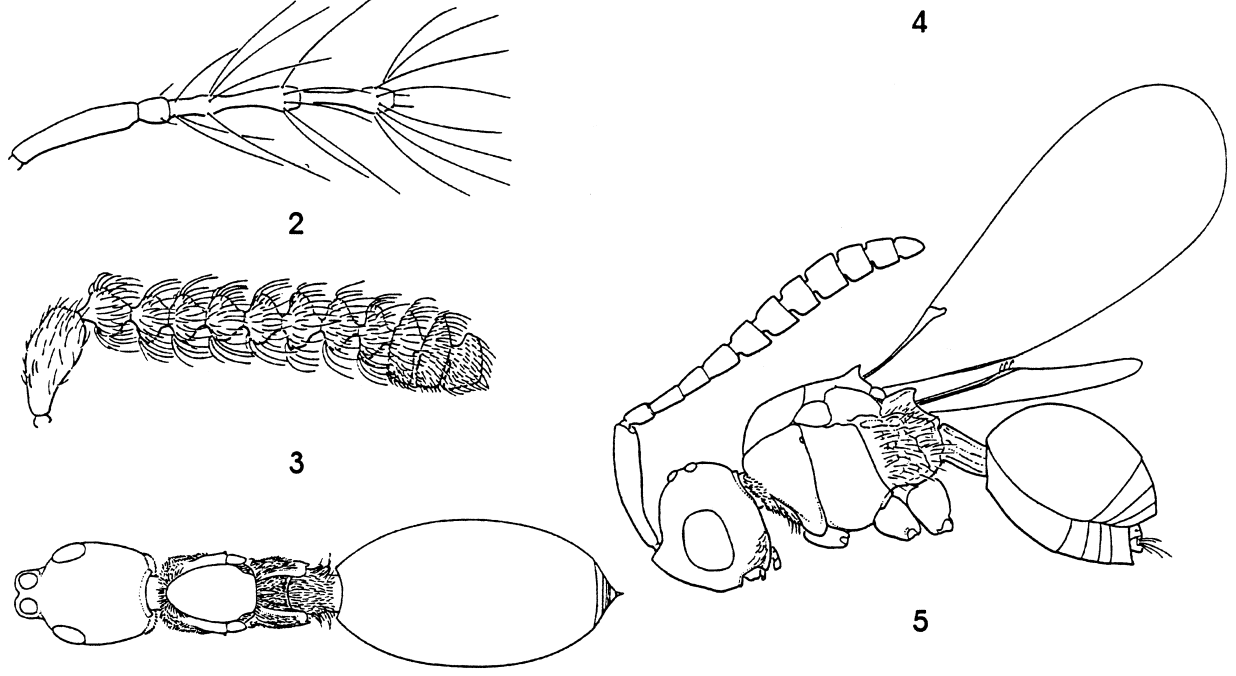

6

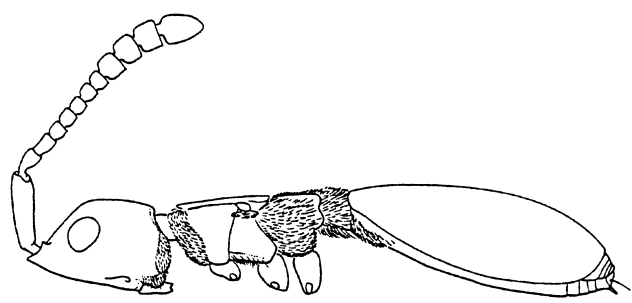

7
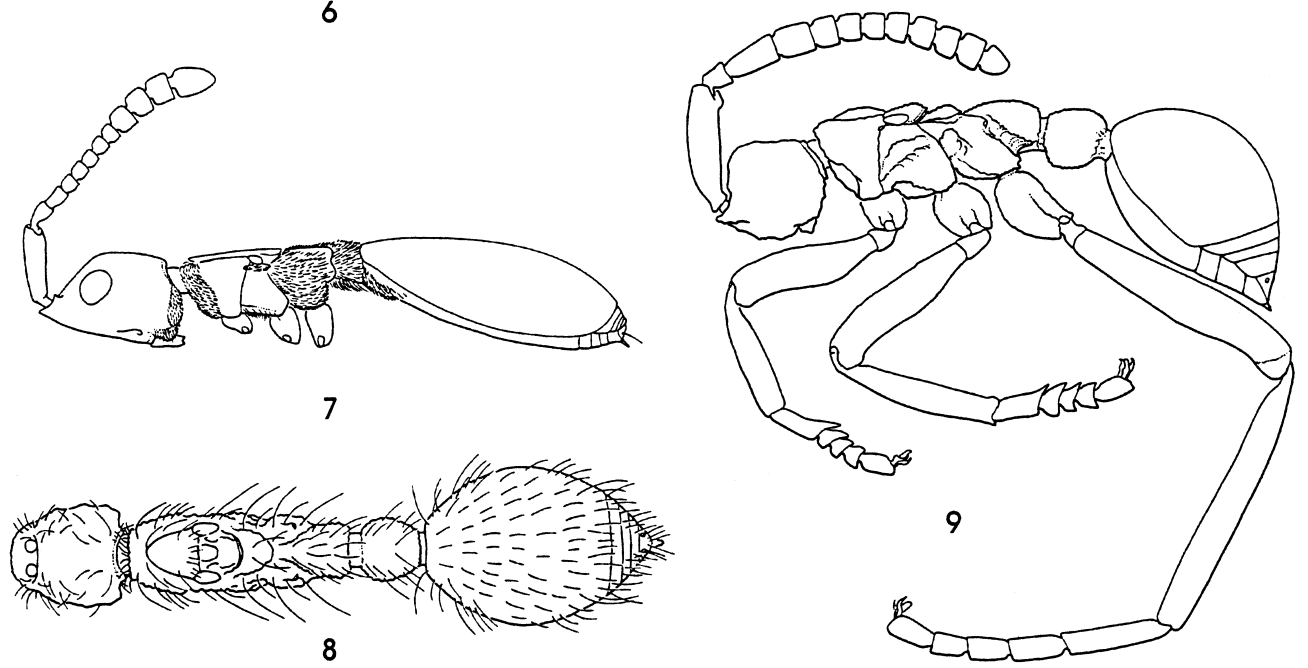

Figs. 1-9. 1, Acanthopria crassicornis Ashmead, male, antenna; 2, A. crassicornis male, A1, A2, A3 + A4, A5; 3, Acathopria sp. female, antenna; 4, Acanthopria sp. female, forewing; 5, A. crassicornis female habitus, lateral view; 6, Aneuropria sp. female habitus, dorsal view; 7, Aneuropria sp. female habitus, lateral view: 8, Apopria coveri n. sp. female habitus, dorsal view; 9, Apopria coveri n. sp. female habitus, lateral view (pilosity omitted). 


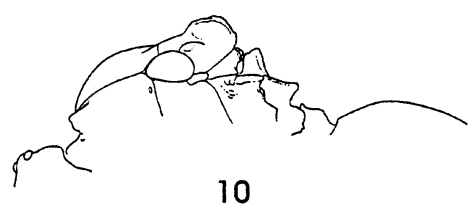

10
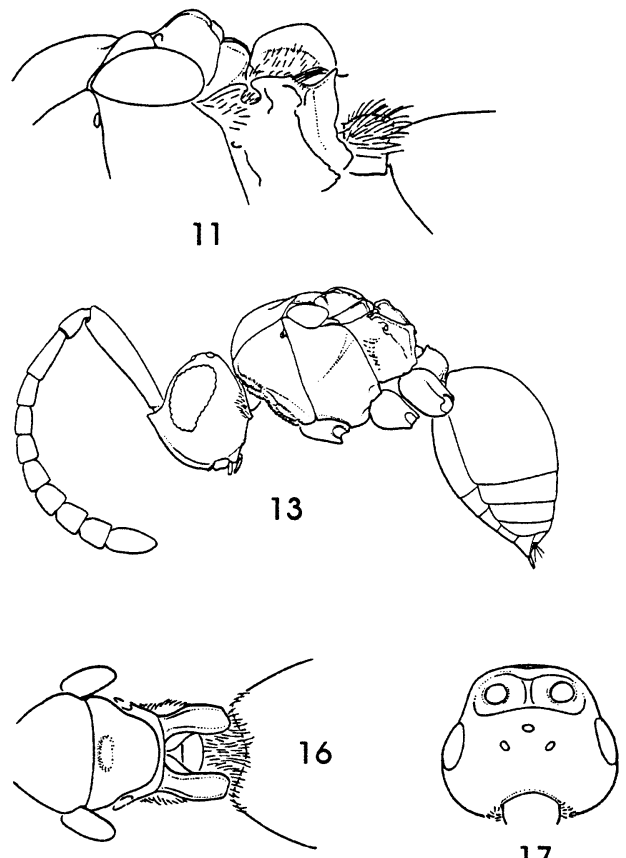

17

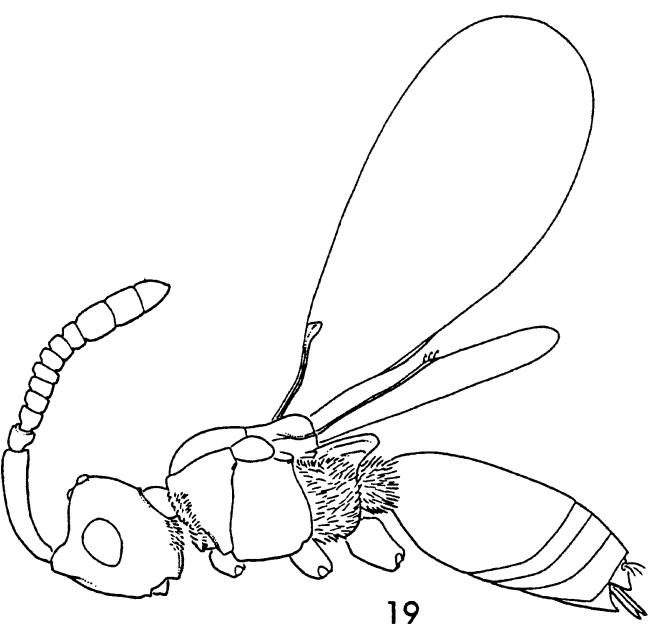

19

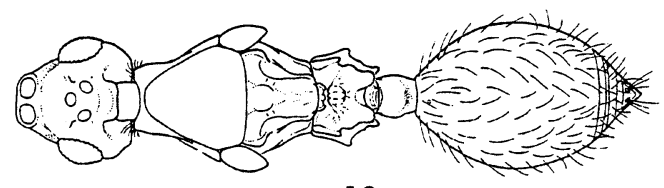

12

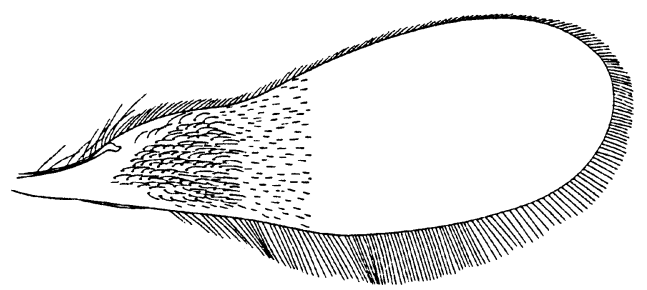

14
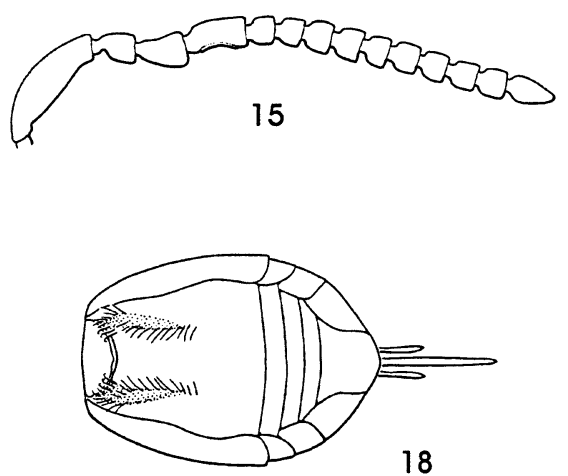

18

Figs. 10-20. 10, Asolenopsia gibba n. sp. female, lateral view; 11, Asolenopsia sp. female, lateral view;12, Asolenopsia gibba n. sp., female habitus, dorsal view; 13, Asolenopsia sp. female habitus, lateral view; 14, Asolenopsia sp., female forewing; 15, Auxopaedeutes lyriformis Brues, male antenna; 16, A. lyrifornis female, dorsal view; 17, A. lyriformis female head, dorsal view; 18, A. lyriformis female metasoma, ventral view; 19, A. lyriformis female habitus, lateral view; 20, Avoca collaris n. sp. female habitus, dorsal view. 

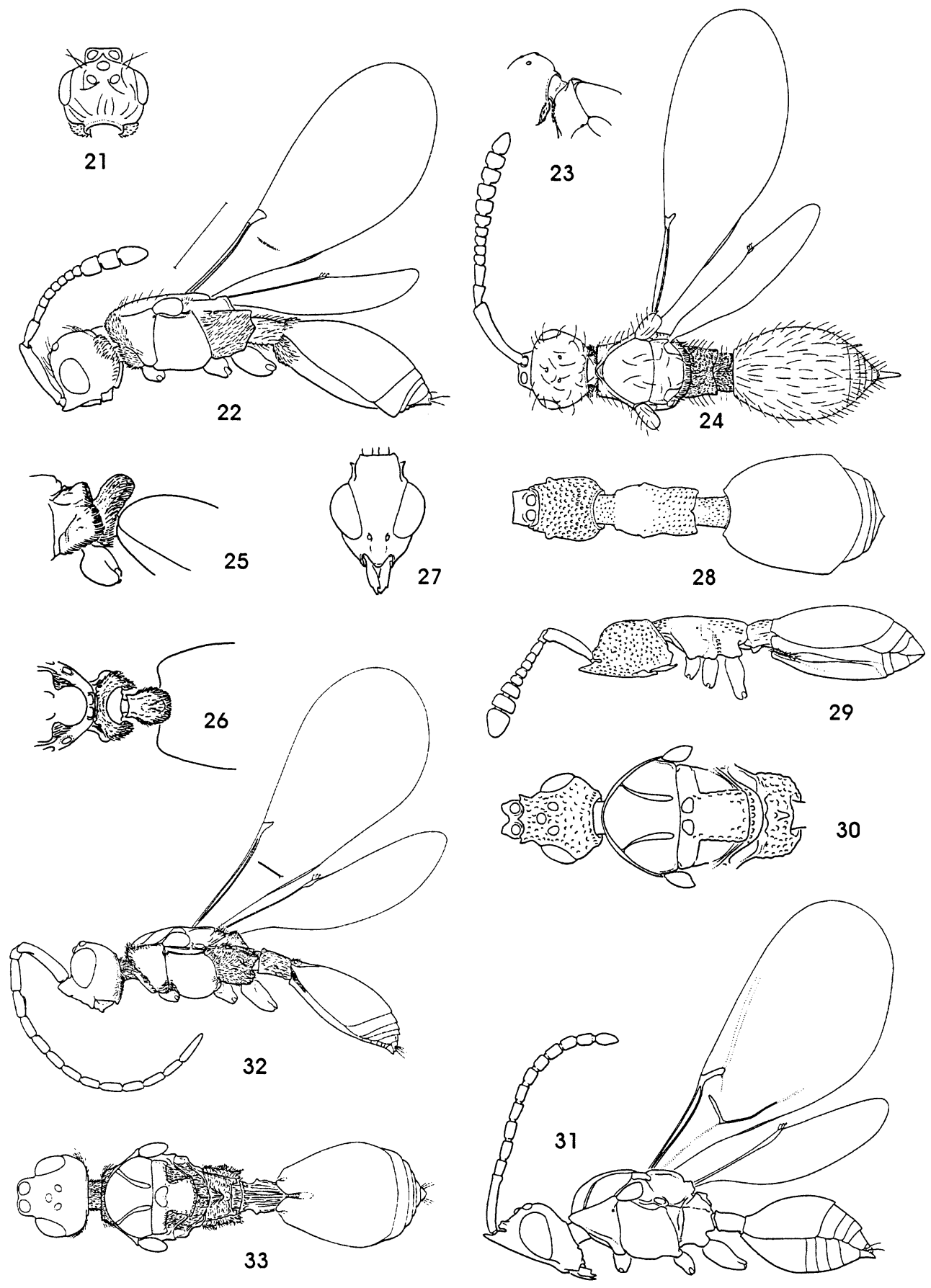

Figs. 21-33. 21, Basalys sp. female head, dorsal view; 22, Basalys sp. female habitus, lateral view; 23, Bruchopria sp. female pronotum, lateral view; 24, Bruchopria sp. female habitus, dorsal view; 25, Bruesopria sp. female, lateral view; 26, Bruesopria sp. female, dorsal view; 27, Caecopria sp. male head, frontal view; 28, Caecopria sp. female habitus, dorsal view; 29, Caecopria sp. female habitus, lateral view; 30, Caecopria sp. male, dorsal view; 31, Caecopria sp. male habitus, lateral view; 32, Chilomicrus pecki n. sp. male habitus, lateral view; 33, C. pecki male habitus, dorsal view. 

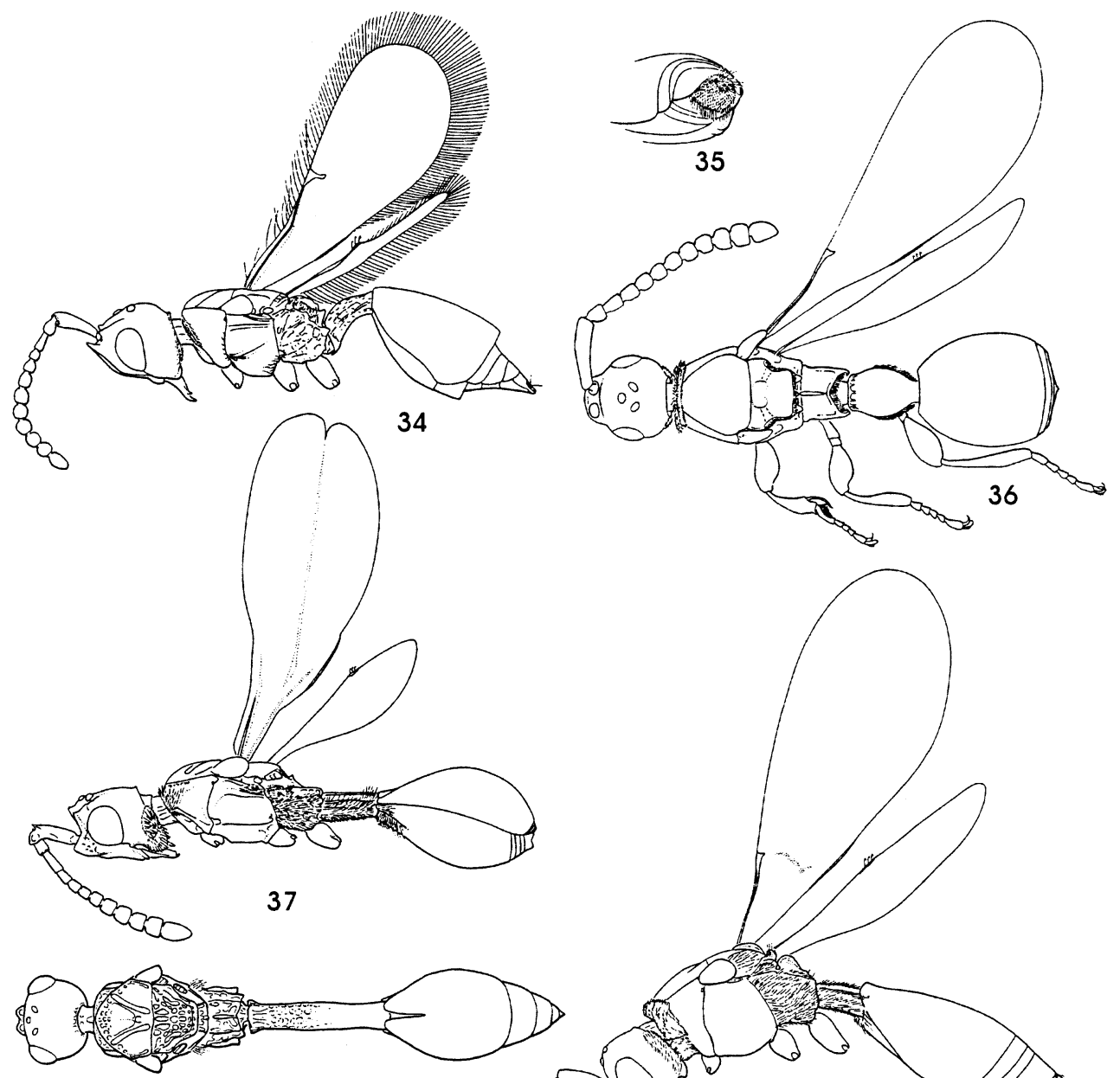

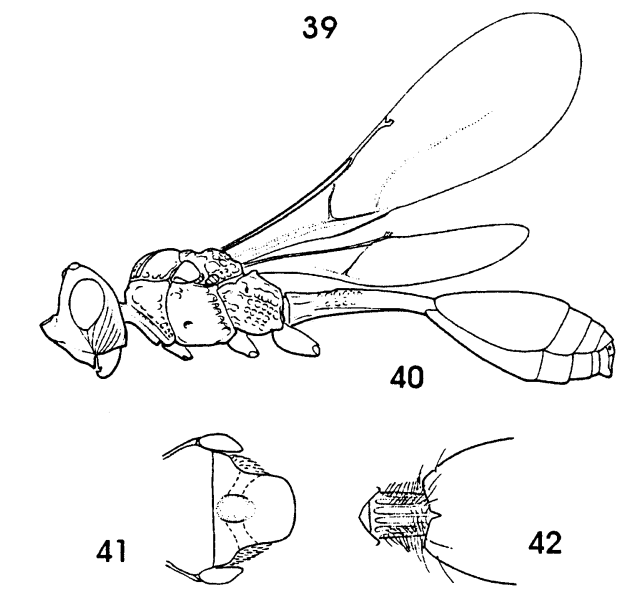

39

40

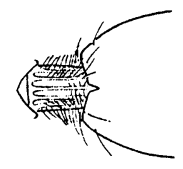

42

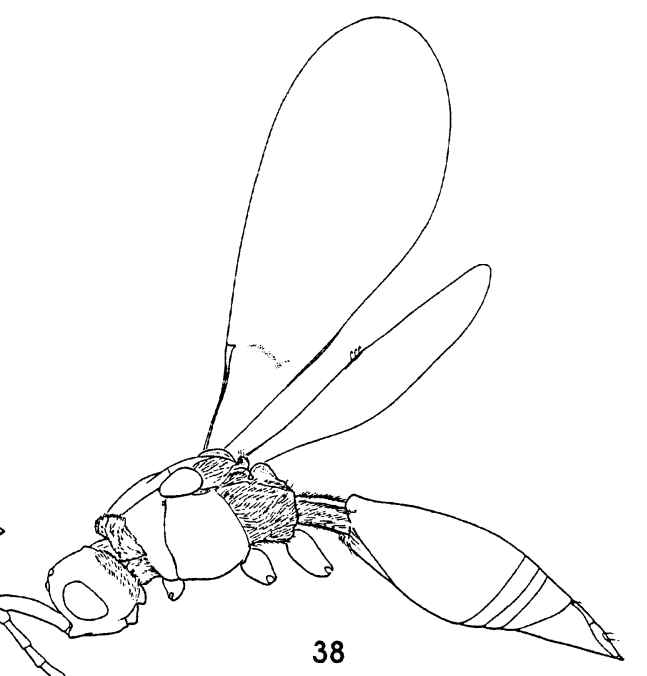

38

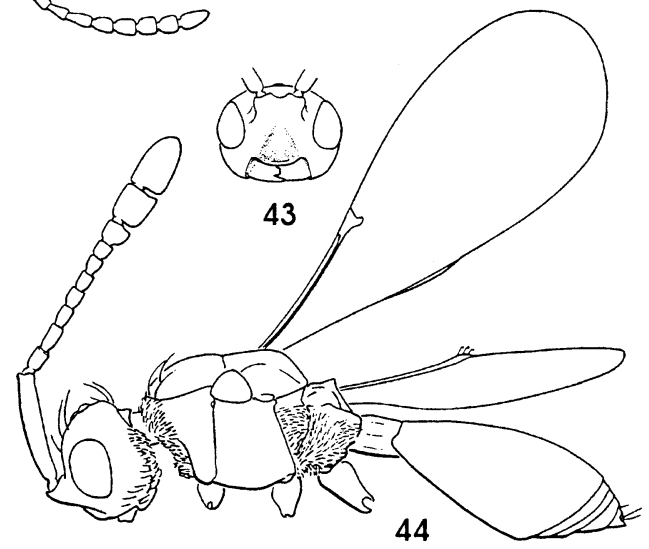

Figs. 34-44. 34, Calogalesus sp. female habitus, lateral view; 35, Cruzia amphoralis n. sp. female, apical tergite; 36, C. amphoralis female habitus, dorsal view; 37, Coptera sp. female habitus, lateral view; 38, Diapria conica (Fabricius) female habitus, lateral view; 39, Doddius sp. female habitus, dorsal view; 40, Doddius sp. female habitus, lateral view; 41, Doliopria sp. female mesosoma, dorsal view; 42, Doliopria sp. female petiole dorsal view; 43, Doliopria sp. female head, frontal view; 44, Doliopria sp. female habitus, lateral view. 

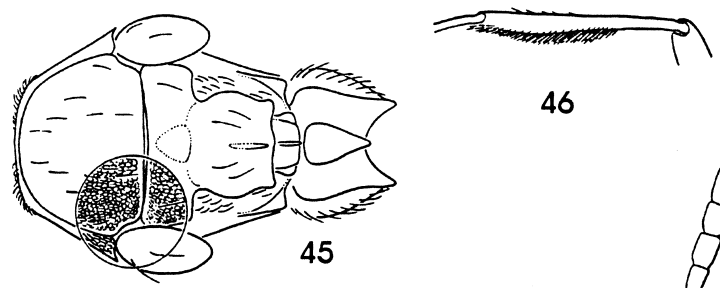

46

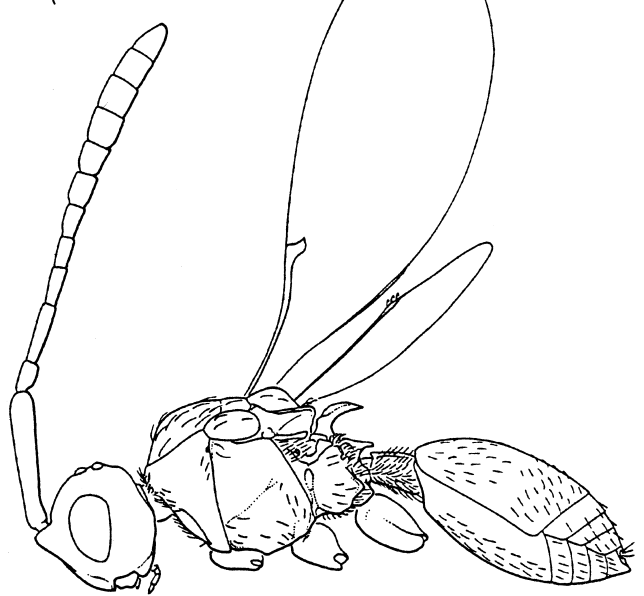

47

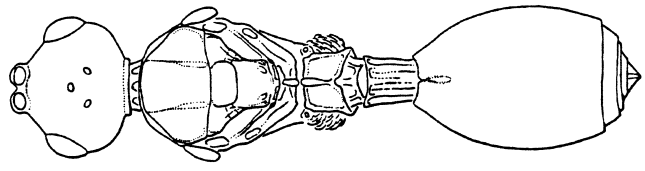

49

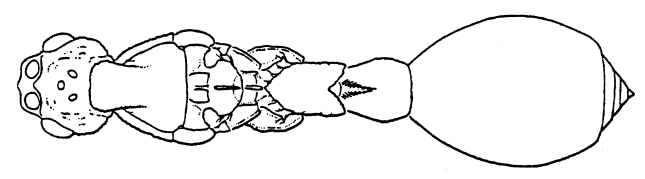

51
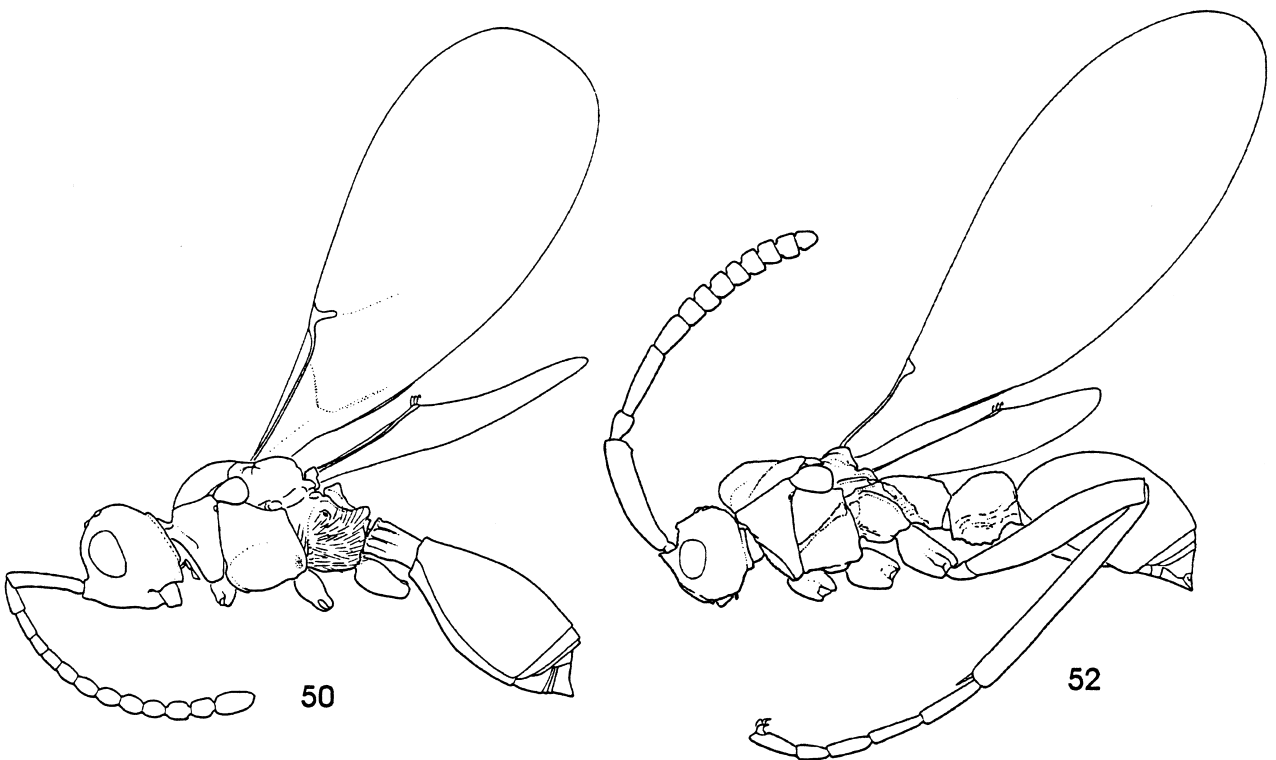

Figs. 45-52. 45, Eladio cruzi n.sp. female mesosoma, dorsal view; 46, E. cruzi female, leg; 47, E. cruzi female habitus, lateral view; 48, Entomacis sp. (Chile), female, forewing; 49, Entomacis sp. female habitus, dorsal view; 50, Entomacis sp. female habitus, lateral view; 51, Ecitovagus gibbus Masner, female habitus, dorsal view; 52, E. gibbus female habitus, lateral view. 

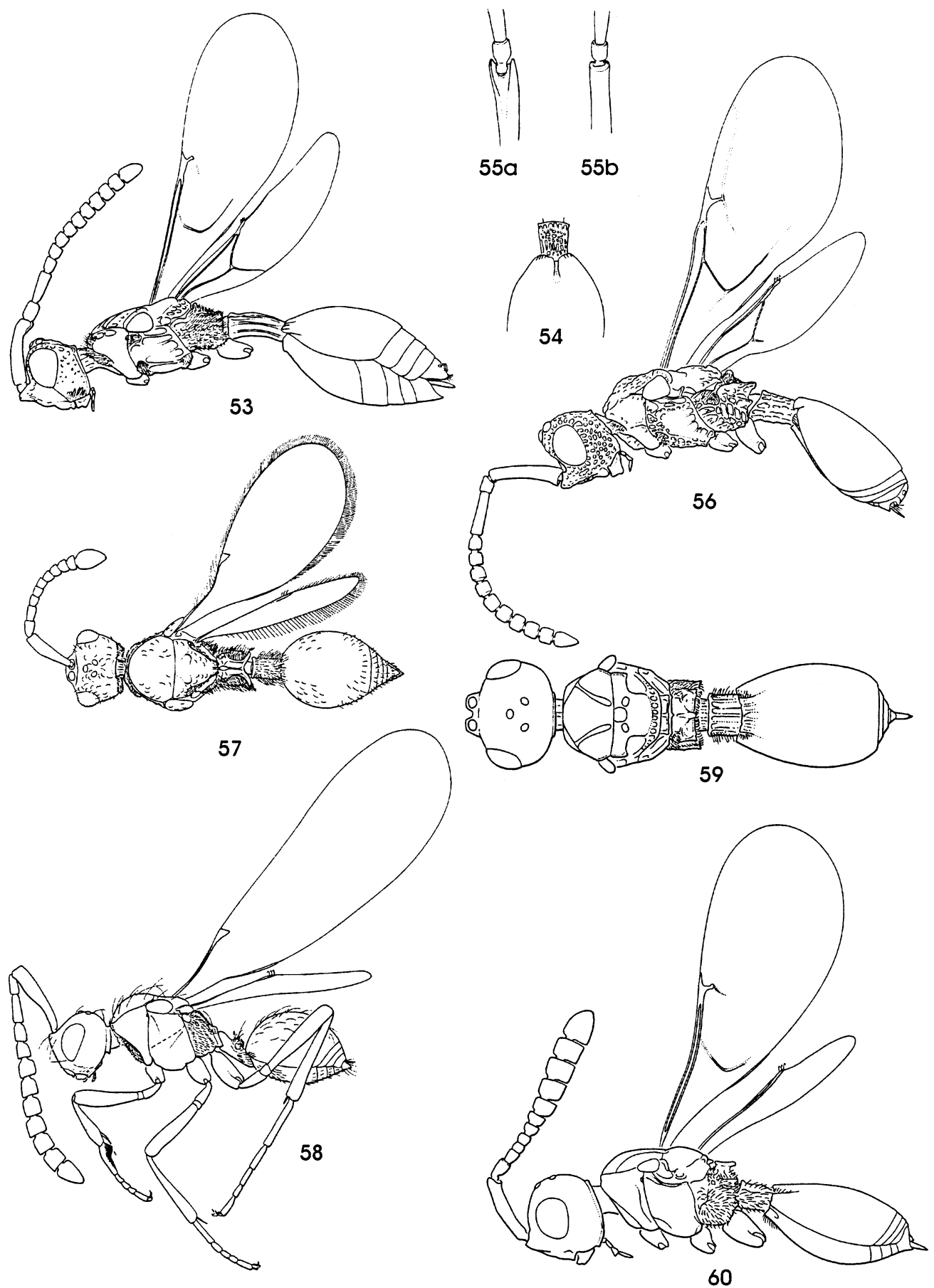

Figs. 53-60. 53, Epomium cicatrix n. sp. female habitus, lateral view; 54, Ferrugenus chilensis n. sp. metasoma, dorsal view; 55a, Spilomicrus sp. A1-A2; 55b, Ferrugenus chilensis A1-A2; 56, Ferrugenus chilensis habitus, lateral view; 57, Hansona pauli $\mathrm{n}$. sp. habitus, dorsal view; 58, Labidopria sp. habitus, dorsal view; 59, Idiotypa sp. habitus, dorsal view; 60, Idiotypa sp. habitus, lateral view. 

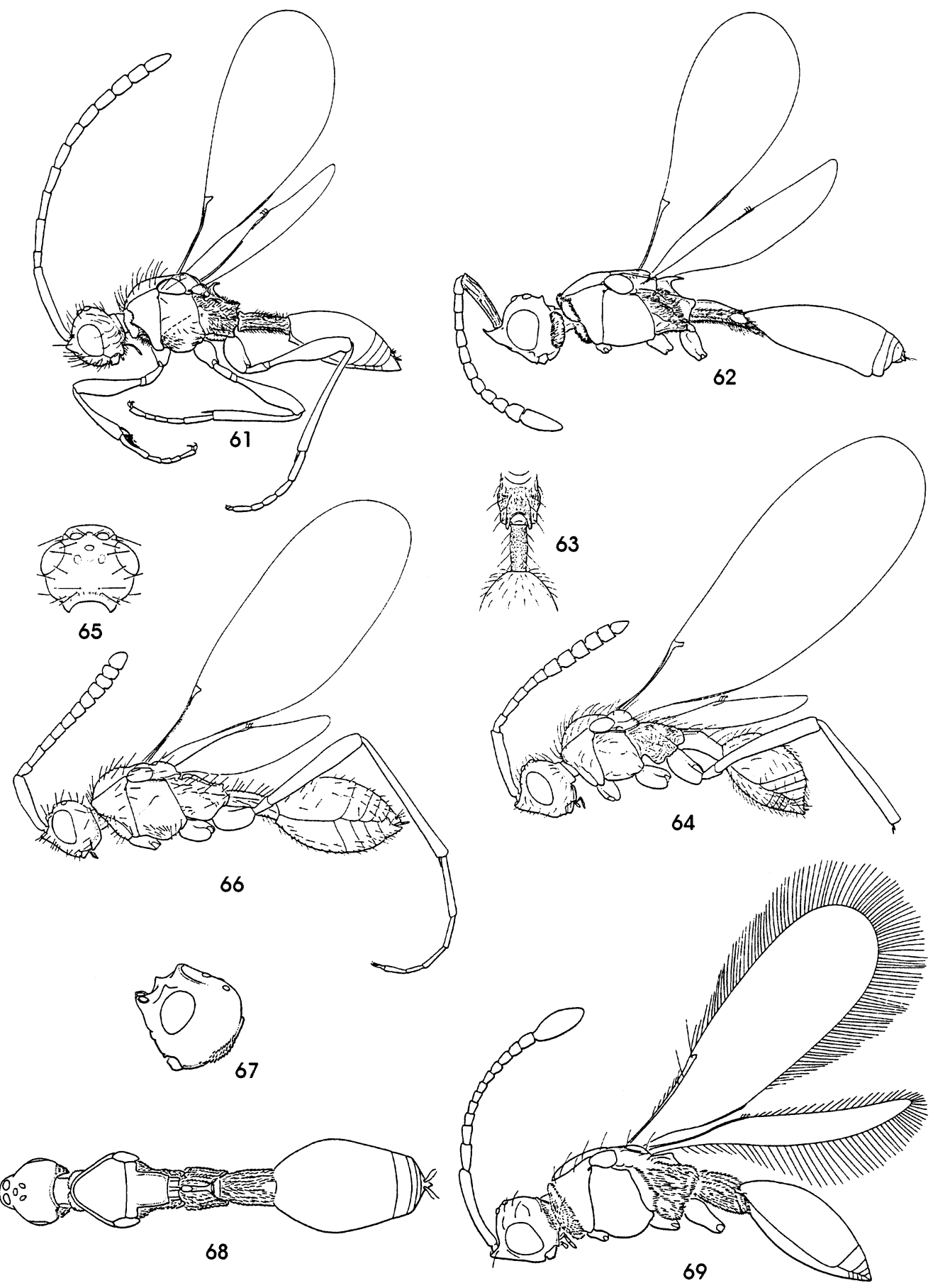

Figs. 61-69. 61, Leucopria cylindricornis n. sp. female habitus, lateral view; 62, Megalastopria sp. female habitus, lateral view; 63, Mimopriella sp. female petiole, dorsal view; 64, Mimopriella sp. female habitus, lateral view; 65, Mimopria comes Borgmeier female head, dorsal view; 66, M. comes female habitus, lateral view; 67, Mitropria sp. female head, lateral view; 68, Monelata sp. female habitus, dorsal view; 69, Monelata sp. female habitus, dorsal view. 

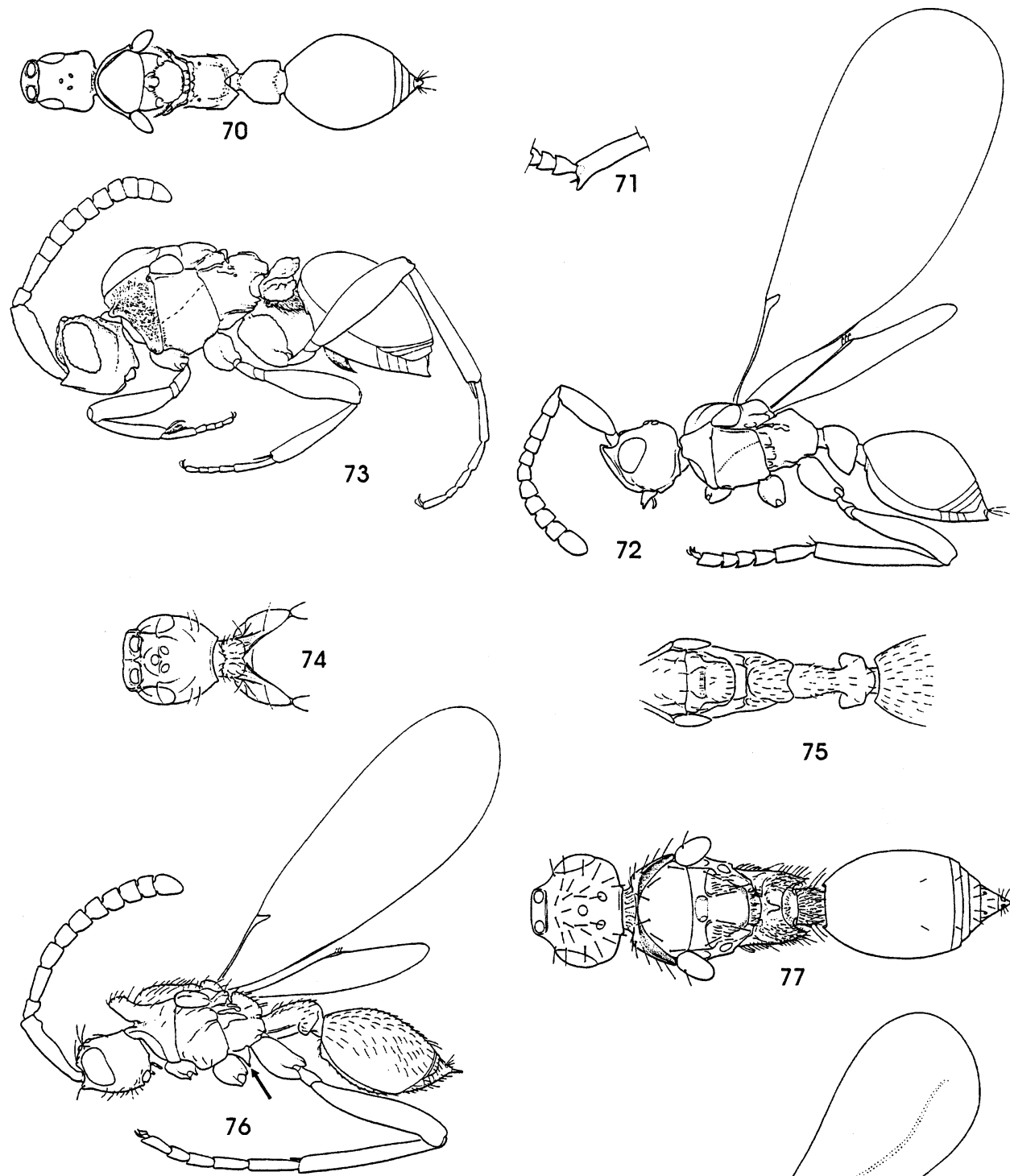

75
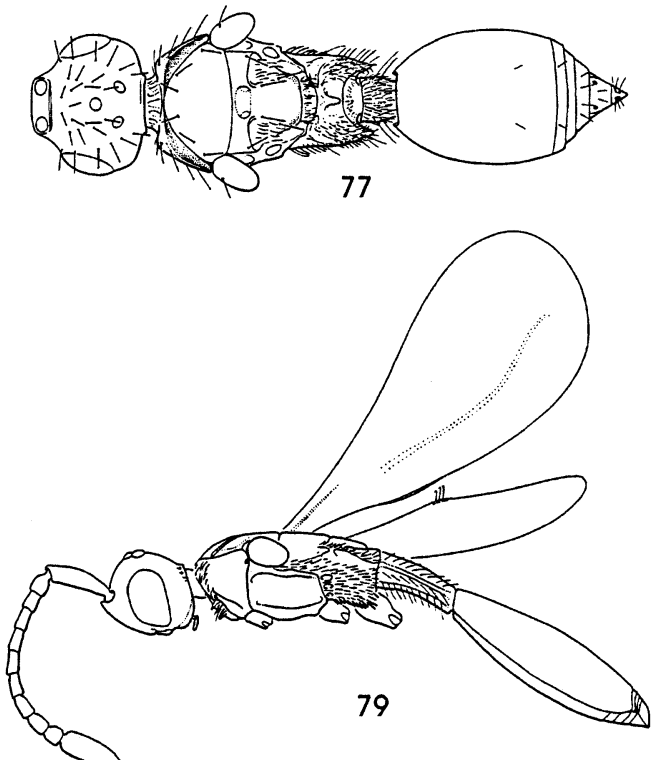

Figs. 70-79. 70, Myrmecopria mellea (Ashmead) female habitus, dorsal view; 71, M. mellea female, tarsomeres; 72, M. mellea female habitus, lateral view; 73, Neivapria penicillata Borgmeier, female habitus, lateral view; 74, Notoxoides sp. female head\&ndash'onotum, dorsal view; 75, Notoxoides sp. female mesosoma, dorsal view; 76, Notoxoides sp. female habitus, lateral view; 77, Omopria brevipalpis n. sp. female habitus, dorsal view; 78, Ortona hansoni $\mathrm{n}$. sp. female habitus, dorsal view; $\mathbf{7 9}, O$. hansoni female habitus, lateral view. 

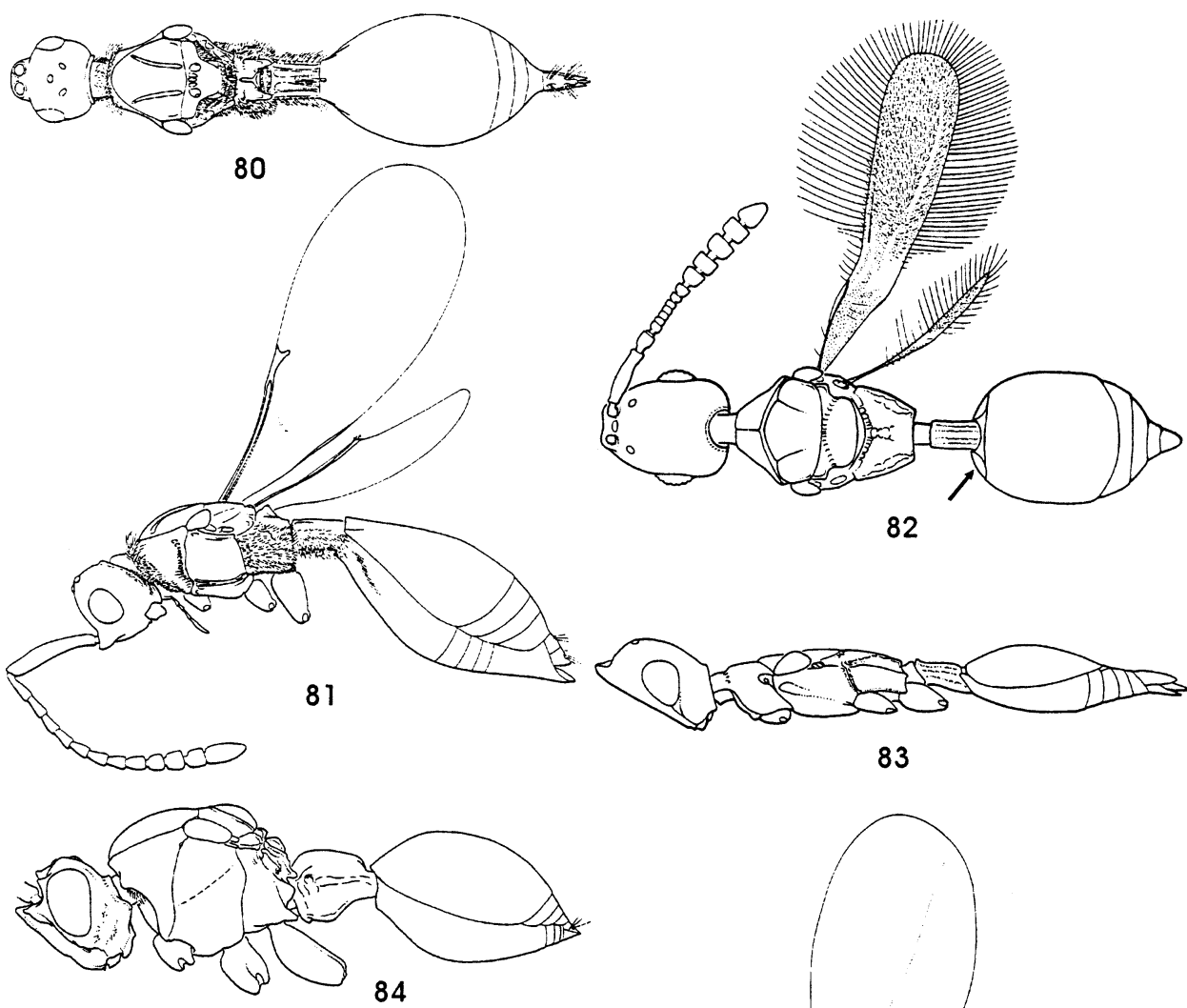

82

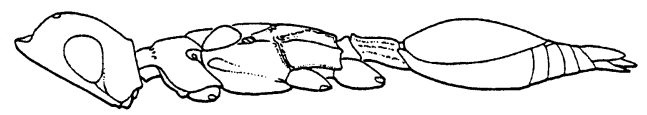

83
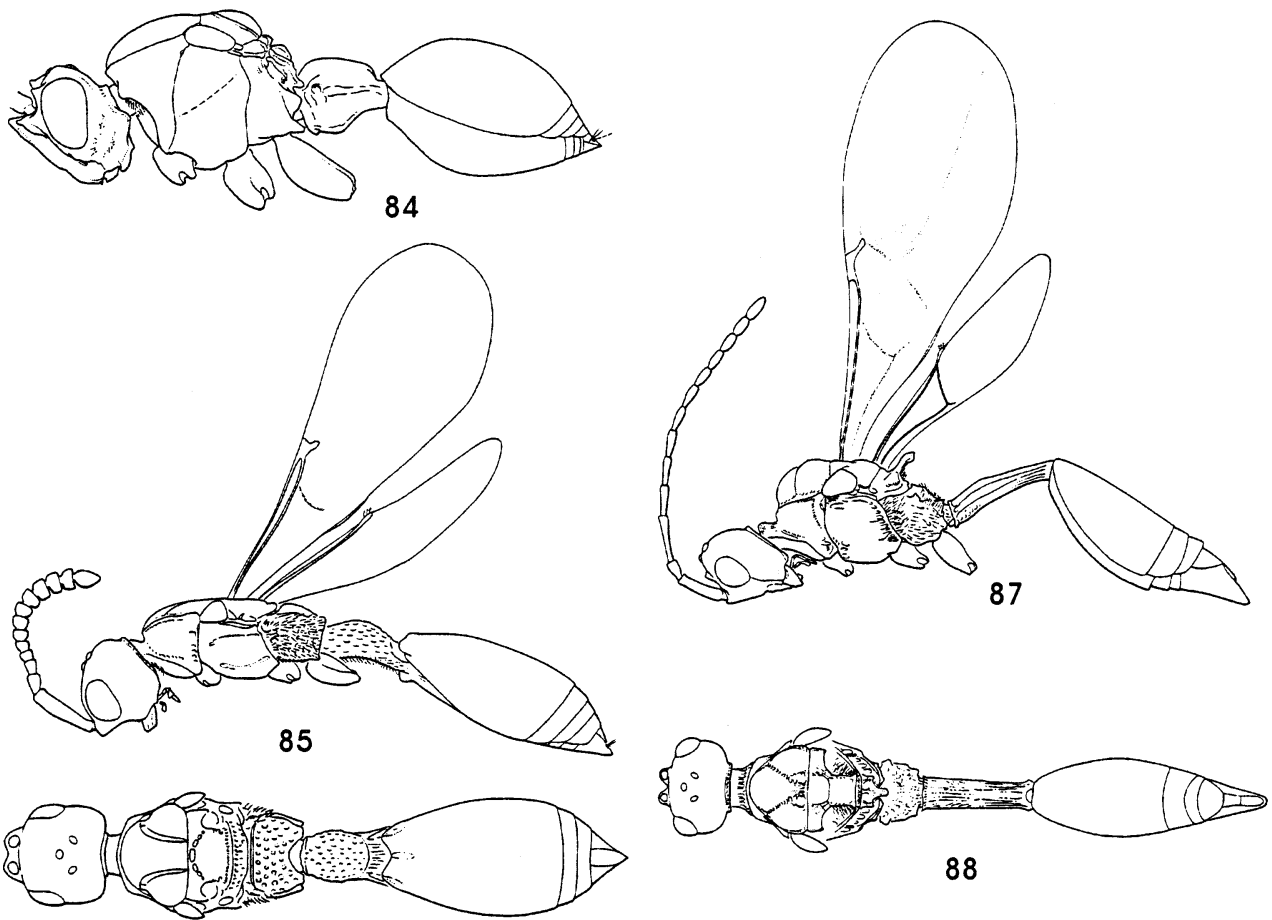

86

Figs. 80-88. 80, Paramesius sp. female habitus, dorsal view; 81, Paramesius sp. female habitus, lateral view; 82, Peckidium enigmaticum n. sp. female habitus, dorsal view; 83, $P$. enigmaticum female habitus, lateral view; 84, Philolestoides sp. female habitus, lateral view; 85, Pentapria sp. female habitus, lateral view; 86, Pentapria sp. female habitus, dorsal view; 87, Poecilopsilus sp. female habitus, lateral view; 88, Poecilopsilus sp. female habitus, dorsal view. 

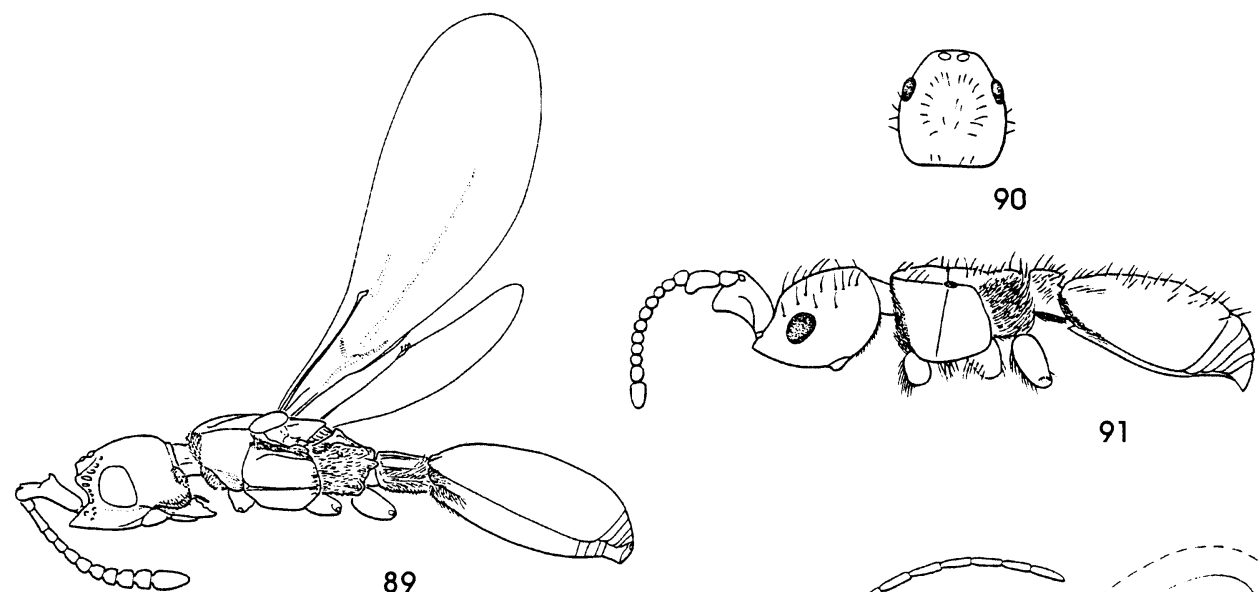

91
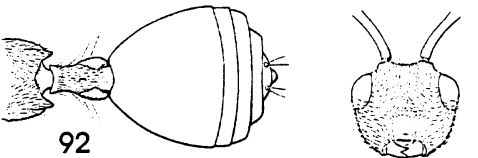

93
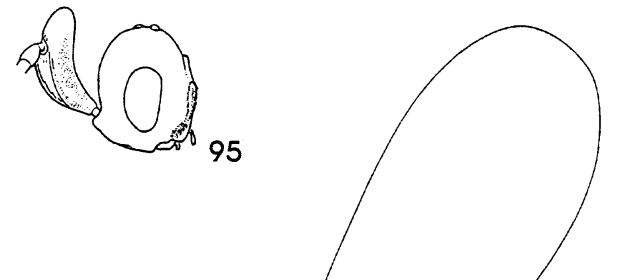

$94 a$
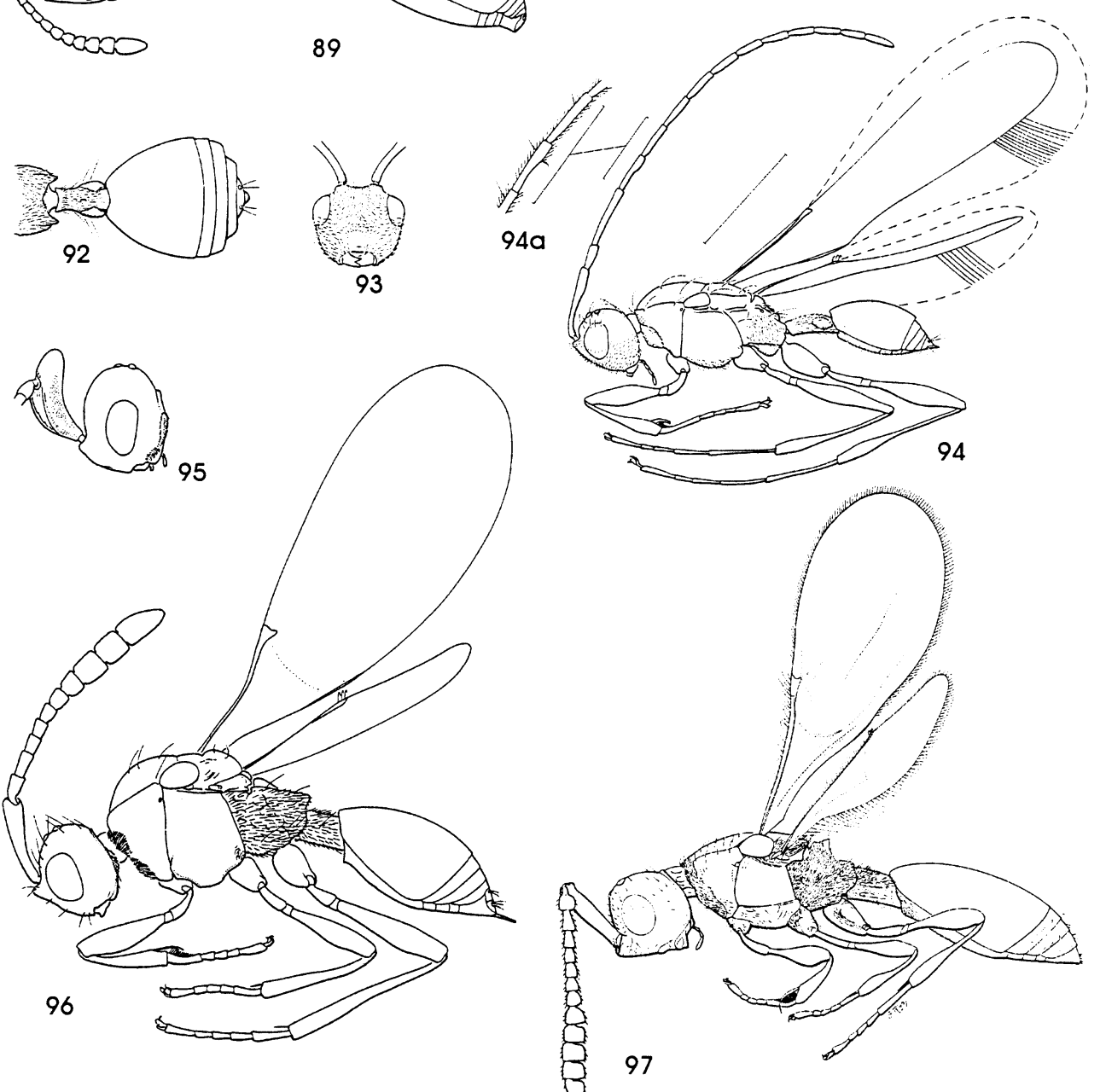

Figs. 89-97. 89, Psilus sp. female habitus, lateral view; 90, Platymischus dilatatus, lateral view; 92, Psychopria hoguei n. sp. male metasoma, dorsal view; 93, P. hoguei male head, frontal view; 94, $P$. hoguei male habitus, lateral; 94a, P. hoguei male, A4-A5; 95, Szelenyisca sp. female head, lateral view; 96, Szelenyiopria sp. female habitus, lateral view; 97, Spilomicrus atriclavus Ashmead, female habitus, lateral view. 

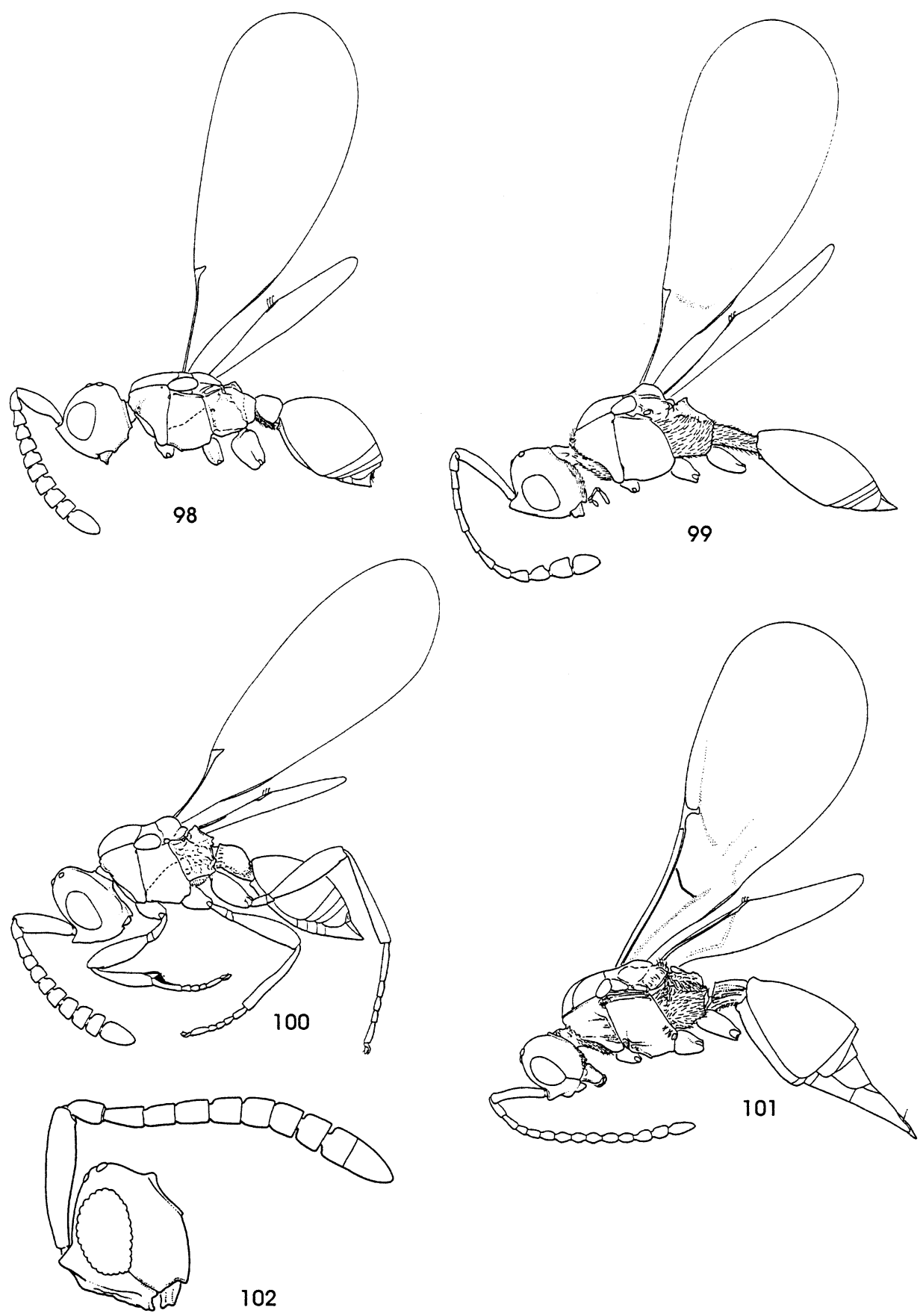

102

Figs. 98-102. 98, Townesella marjoriae Huggert \& Masner, habitus, lateral view; 99, Trichopria sp. habitus, lateral view; 100, Turripria woldai $\mathrm{n}$. sp. habitus, lateral view; 101, Xenismarus sp. habitus, lateral view; 102, Xanthopria sp. habitus, lateral view. 